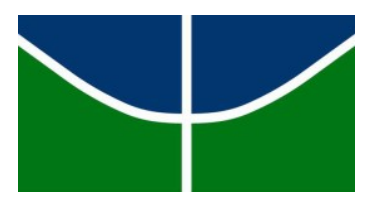

UNIVERSIDADE DE BRASÍLIA

INSTITUTO DE LETRAS - IL

DEPARTAMENTO DE LÍNGUAS ESTRANGEIRAS E TRADUÇÃO - LET

PROGRAMA DE PÓS-GRADUAÇÃO EM LINGUÍSTICA APLICADA - PPGLA

LETRAMENTO CRÍTICO NA SALA DE AULA DE FRANCÊS: FOCO EM IDENTIDADES SOCIAIS DE GÊNERO E RAÇA/ETNIA

WALESCA AFONSO ALVES PÔRTO

DISSERTAÇÃO DE MESTRADO EM LINGUÍSTICA APLICADA

BRASÍLIA/DF

2016 


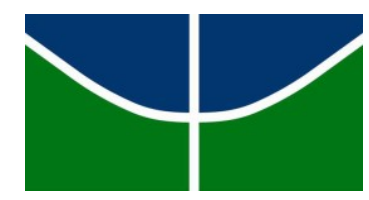

UNIVERSIDADE DE BRASÍLIA

INSTITUTO DE LETRAS - IL

DEPARTAMENTO DE LÍNGUAS ESTRANGEIRAS E TRADUÇÃO - LET

PROGRAMA DE PÓS-GRADUAÇÃO EM LINGUÍSTICA APLICADA - PPGLA

LETRAMENTO CRÍTICO NA SALA DE AULA DE FRANCÊS: FOCO EM IDENTIDADES SOCIAIS DE GÊNERO E RAÇA/ETNIA

\author{
WALESCA AFONSO ALVES PÔRTO
}

ORIENTADORA: PROFA. DRA. MARIANA ROSA MASTRELLA-DE-ANDRADE

DISSERTAÇÃO DE MESTRADO EM LINGUÍSTICA APLICADA 


\section{REFERÊNCIA BIBLIOGRÁFICA E CATALOGAÇÃO}

PÔRTO, Walesca Afonso Alves. Letramento crítico na sala de aula de francês: foco em identidades sociais de gênero e raça/etnia. 2016. 218 f. Dissertação (Mestrado em Linguística Aplicada) - Universidade de Brasília, Brasília, 2016.

Documento formal, autorizando reprodução desta dissertação de mestrado para empréstimo ou comercialização, exclusivamente para fins acadêmicos, foi passado pelo autor à Universidade de Brasília e acha-se arquivado na Secretaria do Programa. O autor reserva para si os outros direitos autorais, de publicação. Nenhuma parte desta dissertação de mestrado pode ser reproduzida sem a autorização por escrito do autor. Citações são estimuladas, desde que citada a fonte.

Ficha catalográfica elaborada automaticamente, com os dados fornecidos pelo(a) autor(a)

PP853

Pôrto, Walesca Afonso Alves

LETRAMENTO CRÍTICO NA SALA DE AULA DE FRANCÊS: FOCO EM IDENTIDADES SOCIAIS DE GÊNERO E RAÇA/ETNIA / Walesca Afonso Alves Pôrto; orientador Mariana Rosa Mastrella-de-Andrade. -- Brasilia, 2016. $218 \mathrm{p}$.

Dissertação (Mestrado - Mestrado em Linguística Aplicada) -- Universidade de Brasilia, 2016.

1. Ensino de línguas. 2. Identidades sociais. 3. Letramento crítico. I. Mastrella-de-Andrade, Mariana Rosa, orient. II. Título. 


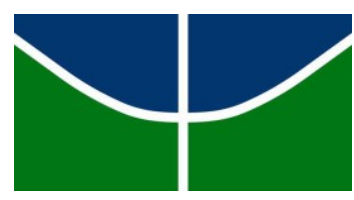

UNIVERSIDADE DE BRASÍLIA

INSTITUTO DE LETRAS - IL

DEPARTAMENTO DE LÍNGUAS ESTRANGEIRAS E TRADUÇÃO - LET

PROGRAMA DE PÓS-GRADUAÇÃO EM LINGUÍSTICA APLICADA - PPGLA

\title{
LETRAMENTO CRÍTICO NA SALA DE AULA DE FRANCÊS: FOCO EM IDENTIDADES SOCIAIS DE GÊNERO E RAÇA/ETNIA
}

\author{
WALESCA AFONSO ALVES PÔRTO
}

\begin{abstract}
Dissertação de mestrado submetida ao Programa de Pós-Graduação em Linguística Aplicada, como parte dos requisitos necessários à obtenção do grau de Mestre em Linguística Aplicada.
\end{abstract}

\section{APROVADA POR:}

Profa. Dra. Mariana Rosa Mastrella-de-Andrade, Universidade de Brasília (UnB) (ORIENTADORA)

Profa. Dra. Rosane Rocha Pessoa, Universidade Federal de Goiás (UFG) (EXAMINADORA EXTERNA)

Profa. Dra. Maria del Carmen de la Torre Aranda, Universidade de Brasília (UnB) (EXAMINADORA INTERNA)

Prof. Dr. Yûki Mukai, Universidade de Brasília (UnB)

(SUPLENTE)

BRASÍLIA/DF - 19 de dezembro de 2016. 
A educação é um processo social, é desenvolvimento. Não é a preparação para a vida. A escola é a própria vida.

John Dewey 
À minha mãe, Gislene, ao meu pai, Mário Nêy, ao meu irmão, Murilo e ao meu noivo, Fábio.

As/Aos professoras/es que buscam um repensar constante da sua práxis e que veem na educação um espaço de reflexão da vida social. 


\section{AGRADECIMENTOS}

A Deus pelo dom da vida, por me guiar em todos os caminhos na certeza de que cada passo meu está nos planos d'Ele.

Aos meus pais, Gislene e Mário Nêy, por acreditarem em mim e sempre me incentivarem a ir atrás dos meus sonhos. Sou grata a Deus por existirem na minha vida. Nada disso seria possível sem vocês! Aos meus avós, Maria Neusa e Elveni, pelo carinho e atenção que sempre tiveram por mim. Vovó, agradeço por todas as suas orações, pela fé e exemplo de pessoa, sempre disposta a ajudar alo próximalo. Te admiro muito! Ao meu irmão, Murilo, pelo apoio e disposição em me ajudar em todos os momentos. Às/Aos minhas/meus primas/os, cunhadas, comadre, tias/os, madrinha e padrinho, obrigada por me fazerem entender o verdadeiro sentido de uma família. Vocês moram no meu coração!

Ao meu noivo, Fábio, pela paciência e escuta constante, pelas palavras que me motivaram a acreditar que esse sonho era possível. Você ilumina a minha vida! À sua mãe, Amélia e sua irmã Kamila, pela atenção e carinho.

Às/Aos minhas/meus colegas de mestrado "especial”: Rossini, Arleane, Lauro e Rosilene. Obrigada pelo apoio e incentivo na seleção e escrita do meu projeto de mestrado.

A todas/os as/os minhas/meus colegas de mestrado, pelos momentos "brilhantes" que passamos juntas/os. Vocês fizeram dessa caminhada acadêmica um momento prazeroso e enriquecedor. Ao Glauco Wright, pela ajuda na escrita do abstract deste trabalho.

À ma chère Uliana Anufrieva, pela amizade e ajuda na escrita do résumé deste trabalho. Je suis fière de notre amitié qui au long du temps est devenue encore plus forte.

À Profa. Dra. Maria da Glória Magalhães dos Reis, pela alegria contagiante, pelo comprometimento, pelos diálogos e conhecimentos compartilhados durante esse período. Você é um exemplo para mim!

As Profas. Dras. Maria da Glória Magalhães dos Reis e Lúcia Maria de Assunção Barbosa, pelo olhar sensivel e críticas produtivas na minha qualificação de mestrado. Os seus conselhos orientaram a escrita deste trabalho.

À Profa. Dra. Mariana Rosa Mastrella-de-Andrade, pela simpatia e carisma, pela leitura atenta e pelos momentos de reflexão valiosos na orientação desta pesquisa. Suas aulas e palavras me proporcionaram reconstruir e ressignificar minhas múltiplas identidades, além de me incentivarem a trazer uma perspectiva mais social e crítica para as minhas aulas.

Às/aos professoras/es do Programa de Pós-Graduação em Linguística Aplicada (PPGLA): Dra. Mariana Rosa Mastrella-de Andrade, Dra. Lúcia Maria de Assunção Barbosa, Dr. José Carlos Paes de Almeida Filho e Dr. Yûki Mukai, pelos ensinamentos e comprometimento com a formação de professoras/es.

Ass/Aos professoras/es Dras/es. Rosane Rocha Pessoa, Maria del Carmen de la Torre Aranda e Yûki Mukai, pela gentileza em aceitar nosso convite para participar da minha banca de mestrado e compartilhar seus pontos de vista e perspectivas para o refinamento da pesquisa. 
Às/ Aos funcionárias/os do PPGLA, em especial ao Thiago e à Nina, pela prestatividade e gentileza no atendimento.

À Secretaria de Estado de Educação do Distrito Federal (SEEDF) pela licença a mim concedida para que eu pudesse desenvolver esta pesquisa com afinco e dedicação. Sou muito grata pela oportunidade. A formação de professoras/es é crucial para uma educação problematizadora.

À Elisabeth Ranedo, diretora da Aliança Francesa (AF) de Brasilia no momento em que esta pesquisa foi realizada, por possibilitar desenvolver este estudo e por confiar no meu trabalho.

Ao Guillaume Perche, coordenador da AF de Brasilia, pela atenção, ajuda e disposição constantes. Sou grata pela sua amizade!

À Profa. Luciana Bié, colega de trabalho da SEEDF na AF de Brasília, pela disponibilidade em me ceder sua turma para a realização deste trabalho!

À Associação de Professores de Francês do Distrito Federal (APFDF) e à Embaixada da França no Brasil pelo apoio e ajuda de custo para participar do XIVe Congrès mondial realizado em Liège/Bélgica e organizado pela Fédération Internationale des Professeurs de Français (FIPF). Nesse Congresso, pude apresentar e compartilhar um pouco desta pesquisa com outras/os colegas professoras/es de francês de diferentes partes do mundo.

Às/Aos alunas/os agentes desta pesquisa. Obrigada por aceitarem participar deste estudo e pelo comprometimento e engajamento nas interações em sala de aula. Vocês me mostraram que é possível um ensino de línguas transgressor capaz de favorecer a reflexão e problematização das práticas sociais com vistas à formação cidadã. Além disso, me possibilitaram refletir sobre a minha prática pedagógica, reconstruindo a minha identidade de professora de francês. Espero ter contribuído de alguma maneira na vida de vocês! Esta pesquisa é fruto desse trabalho coletivo. A vocês, o meu carinho e reconhecimento! 


\section{RESUMO}

Esta pesquisa busca investigar como o letramento crítico abre espaço para (re)construção de identidades sociais de gênero e raça/etnia com vistas à formação cidadã na sala de aula de francês como língua adicional. O objetivo é problematizar as percepções das/os participantes quanto à dinâmica dessas identidades na sociedade, analisando as possibilidades e os desafios de trabalhar nessa perspectiva pedagógica, bem como o seu desdobramento na formação de cidadãs/os críticas/os e reflexivas/os. O estudo ocorreu no primeiro semestre de 2016 na escola Aliança Francesa de Brasília em uma turma de alunas/os de nível intermediário de francês. Para tanto, esta pesquisa ancora-se nos seguintes construtos e teóricos: identidades como construção (HALL, 2014; WOODWARD, 2014; SILVA, 2014; NORTON, 2000); identidades como indissociáveis do ensino de línguas (FERREIRA; BRIGOLLA, 2013; MASTRELLA-DE-ANDRADE, 2010); identidades de gênero e raça/etnia como socialmente construídas (LOURO, 2003, 2008; AUAD, 2003; SCOTT, 1995; MUNANGA, 2005; OLIVEIRA, 2006; GOMES, 2005a; CRUZ; RODRIGUES; BARBOSA, 2011); letramento crítico (FREIRE, 2011; MONTE MÓR, 2015; MENEZES DE SOUZA, 2011a, 2011b). Com base nesses eixos teóricos, esta pesquisa caracteriza-se por uma pesquisa-ação (BARBIER, 2007; MOITA LOPES, 1996; FRANCO, 2005) de natureza qualitativa interpretativista (FLICK, 2009; MOITA LOPES, 1994). Os dados foram gerados por meio de atividades de intervenção baseadas em situações da contemporaneidade envolvendo questões de gênero e raça/etnia, bem como no livro didático. As/Os participantes se engajaram nas discussões, participando e interagindo dentro das temáticas, trazendo uma visão mais crítica das identidades sociais, indo, muitas vezes, além de opiniões formadas pelo senso comum. Contudo, houve momentos em que seus discursos naturalizaram práticas sociais, o que possibilitou refletir sobre elas. No que tange às possibilidades, o letramento crítico propiciou a problematização de identidades por meio das atividades desenvolvidas, como também pelo questionamento de imagens e discursos presentes no livro didático, mostrando que, como afirma Duboc (2015), podemos agir nas brechas da sala de aula. Um dos desafios encontrados foi o uso da língua-alvo, especialmente no início da pesquisa. Contudo, ao longo do semestre, as/os participantes foram desenvolvendo suas capacidades linguístico-discursivas, passando a usar, cada vez mais, a língua francesa nas interações. O grande desafio, sobretudo, foi na problematização em si, em como agir durante as interações, me levando a refletir que não há regras ou respostas prontas a serem dadas, mas sim possibilidades de repensar as construções identitárias. Com base nos questionários e nas produções escritas, as/os participantes demonstraram a relevância dessa prática pedagógica não apenas para o aprendizado da língua francesa, como também para a formação cidadã, apontando para uma reflexão crítica, tão valiosa em um ensino que se quer transgressivo.

Palavras-chave: Ensino de línguas. Identidades sociais. Letramento crítico. 


\begin{abstract}
This research aims to investigate how critical literacy provides opportunities to (re)construct social identities of gender and race/ethnicity with an eye on the citizenship formation in a classroom environment of French as an additional language. The purpose of this reserach lies on the discussion of the participants' perceptions concerning the dynamics of those identities in society, by analyzing the possibilities and challenges of this pedagogical perspective, as well as its impact on the formation of reflective citizen(s). This study was conducted throughtout the first semester of 2016 at Aliança Francesa school in Brasília, in an intermediate class of French. Therefore, this research relies on the following constructs and authors: identities as construction (HALL, 2014; WOODWARD, 2014; SILVA, 2014; NORTON, 2000); identities as inextricable from language learning (FERREIRA; BRIGOLLA, 2013; MASTRELLA-DE-ANDRADE, 2010); identities of gender and race/ethnicity as socially constructed (LOURO, 2003, 2008; AUAD, 2003; SCOTT, 1995; MUNANGA, 2005; OLIVEIRA, 2006; GOMES, 2005a; CRUZ; RODRIGUES; BARBOSA, 2011); Critical Literacy (FREIRE, 2011; MONTE MÓR, 2015; MENEZES DE SOUZA, 2011a, 2011b). Based on these theoretical areas, this study features a research-action (BARBIER, 2007; MOITA LOPES, 1996; FRANCO, 2005) of interpretative and qualitative nature. Data were generated through intervertion activities in contemporaneity situations regarding gender and race/ethnicity issues, as well as textbook. The participants engaged themselves in discussions by taking part and interacting in the purposed themes, providing a more critical view of social identities, and at times, going beyond the views established by the common sense. However, there were moments where these students'discourses naturalized the social practices which allowed some reflection over them. With regard to the possibilities, the critical literacy made possible to problematize the identities through those developed activities and questionning the images and discourses in the textbook, evidencing, according to Duboc (2015), that we can intervene in the fissures found in class. One of the challenges encountered was the use of target language, mainly, at the beginning of the research. Along the semester, the participants were developing their linguistic-discoursive abilities to the extent of using more and more French in the interactions. Thus, the ultimate challenge was the problematizing per si, in how to behave during the interaction, causing me to think that there are no rules or ready-made answers to be given out, but possibilities to reconsider the identities constructions. On the basis of questionnaires and writing productions, the participants revealed the importance of this pedagogical practice, not only for the French language learning, but also for the citizenship formation which claims for such valuable critical reflection in a learning practice meaning to transgress.
\end{abstract}

Keywords: Language Teaching. Social Identities. Critical Literacy. 


\section{RÉSUMÉ}

Ce mémoire a pour objectif d'analyser de quelle manière la littératie critique donne des opportunités pour la (re)construction des identités sociales de genre et race/ethnie tout en visant la formation citoyenne dans le cours de français langue additionnelle. L'objectif est de remettre en question les perceptions des participants par rapport à ces identités dans la société, en analysant les possibilités et les défis de travailler dans cette perspective pédagogique ainsi que son impact dans la formation de citoyens critiques et réfléchis. L'étude s'est déroulée au premier semestre de 2016 à l'Alliance Française de Brasília avec des élèves de niveau intermédiaire en français. Cette recherche s'est basée sur les termes et théoriciens suivants : identités comme construction (Hall 2014; Woodward 2014; Silva 2014; Norton 2000); identités comme indissociables de l'enseignement de langues (Ferreira; Brigolla 2013; Matrella-de-Andrade 2010); identités de genre et race/ethnie comme socialement construites (Louro 2003 2008; Auad 2003; Scott 1995; Munanga 2005; Oliveira 2006; Gomes 2005a; Cruz; Rodrigues; Barbosa 2011); littératie critique (Freire 2011; Monte Mór 2015; Menezes de Souza 2011a 2011b). Etant donnée ces axes théoriques, cette étude se caracterise par une recherche qualitative interprétative (Flick 2009; Moita Lopes 1994) dont la méthodologie est la recherche-action (Barbier 2007; Moita Lopes 1996; Franco 2005). Les données ont été créés à l'aide des activités d'intervention basées sur des situations de la vie contemporaine concernant des questions de genre et race/ethnie ainsi que sur le manuel utilisé en classe. Les participants ont interagi entre eux et se sont engagés dans les discussions, ils ont participé aux thématiques en apportant une vision plus critique au sujet des identités sociales, allant, plusieurs fois, au-delà des opinions formées par le sens commun. Néanmoins, il y a eu des moments où leurs discours ont essencialisé les pratiques sociales, ce qui a permis d'y réfléchir. En ce qui concerne les possibilités de travailler dans cette perspective d'enseignement, la littératie critique a favorisé la remise en question des identités grâce aux activités développées aussi bien que par la réflexion des images et des discours présents dans le manuel tout en montrant que l'on peut agir dans les opportunités qui émergent de la salle de classe (Duboc 2015). Un des défis rencontrés était l'usage de la langue-cible, en particulier au début de la recherche. Cependant, tout au long du semestre, les participants ont développé leurs capacités linguistiques et discursives en utilisant de plus en plus la langue française dans les interactions. Le grand défi a surtout été dans la problématisation en soi, la manière d'agir lors des interactions, ce qui nous a mené à réfléchir qu'il n'y a pas de règles ou de bonnes réponses toutes prêtes mais des possibilités de repenser les constructions identitaires. Dans les questionnaires et les productions écrites les participants ont souligné l'importance de cette pratique pédagogique non seulement pour l'apprentissage de la langue française mais aussi pour la formation citoyenne, en indiquant une réflexion analytique si importante dans un enseignement critique.

Mots-clés : Enseignement de langues. Identités sociales. Littératie critique. 


\section{SÍMBOLOS DAS TRANSCRIÇÕES DOS DADOS}

... Indicam declínio na entonação da fala seguido de pausa

(...) Indicam corte de parte de fala

[ ] Indicam comentário sobre a qualidade das falas e/ou explanações a respeito do contexto

Observações:

1. Os símbolos aqui adotados foram retirados convenientemente de trabalhos científicos diversos, não sendo, portanto, indicadas as fontes. Foram escolhidos os símbolos mais comumente adotados nos diversos trabalhos pesquisados para as funções aqui necessárias. 
LISTA DE ABREVIATURAS
AF - Aliança Francesa
BNCC - Base Nacional Comum Curricular
CIL - Centro Interescolar de Línguas
ENEM - Exame Nacional do Ensino Médio
IBGE - Instituto Brasileiro de Geografia e Estatística
IPEA - Instituto de Pesquisa Econômica Aplicada
LA - Linguística Aplicada
LDB - Lei de Diretrizes e Bases da Educação Nacional
OCEMs - Orientações Curriculares para o Ensino Médio
PCNs - Parâmetros Curriculares Nacionais
PNAD - Pesquisa Nacional por Amostra de Domicílios
PPGLA - Programa de Pós-Graduação em Linguística Aplicada
SEEDF - Secretaria de Estado de Educação do Distrito Federal
UnB - Universidade de Brasília 


\section{LISTA DE TABELAS}

Tabela 1 - Perfil das/os participantes da pesquisa 69

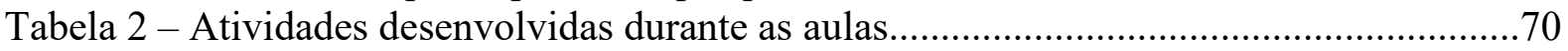

Tabela 3 - Vantagens e desvantagens de ser homem.........................................................97

Tabela 4 - Vantagens e desvantagens de ser mulher............................................................ 97

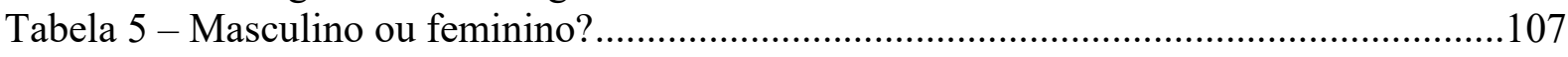

Tabela 6 - Excertos das/os participantes nas produções escritas e no questionário final........182 


\section{LISTA DE IMAGENS}

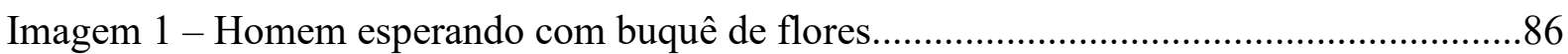

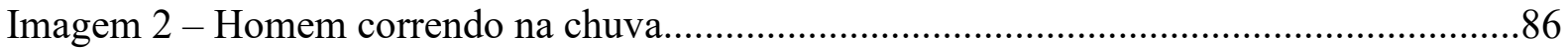

Imagem 3 - Atividades propostas pelo livro didático: Jacques Brel e Madeleine....................87

Imagem 4 - Masculino ou feminino?........................................................................107

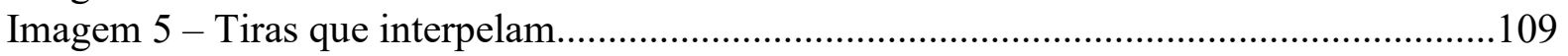

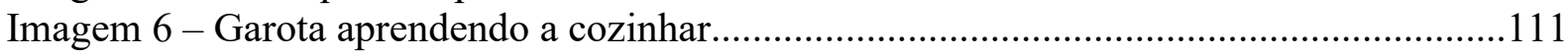

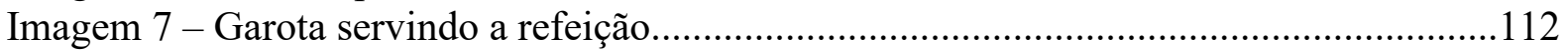

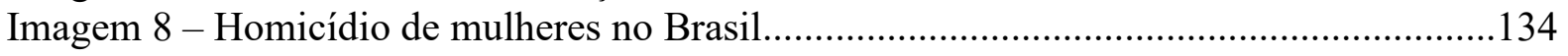

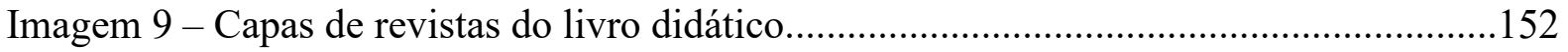

Imagem 10 - “(...) não se nasce mulher, torna-se mulher”................................................159

Imagem 11 - “(...) as bases da sociedade humana são construídas por dois

gêneros (...)"

Imagem 12 - "A identidade de gênero é saber como um indivíduo se identifica

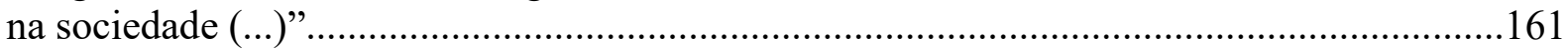

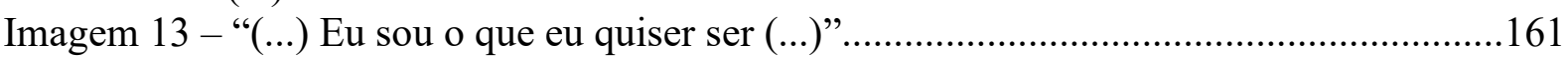

Imagem 14 -“"Tudo começa com os brinquedos que a criança ganha (...)"...........................162

Imagem 15 - "O problema do gênero começa na sociedade, onde os arquétipos

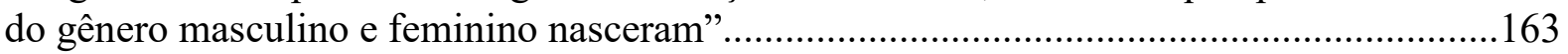

Imagem 16 - "De acordo com a sociedade a mulher deve estar na cozinha (...)"..................163

Imagem 17 - “(...) quando nós tivermos filhos, nós devemos deixá-los escolher

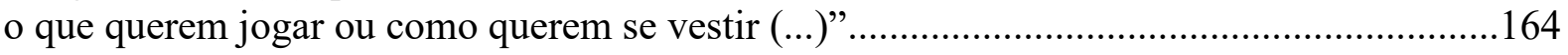

Imagem 18 - "Os tempos mudam e é necessário estabelecer novas regras que

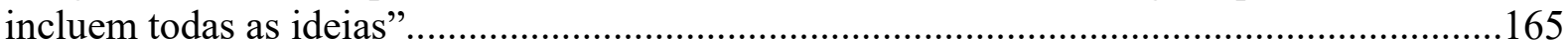

Imagem 19 - “(...) a luta por igualdade para todas as mulheres é importante (...)”...............165

Imagem 20 - “(...) mas onde está a integração?”..............................................................166

Imagem 21 - “(...) a origem da desigualdade no Brasil vem do passado (...)”......................167

Imagem 22 - “(...) as mulheres brancas recebem mais que a mulher negra (...)"...................167

Imagem 23 - "A população brasileira vive ainda diante de uma grande

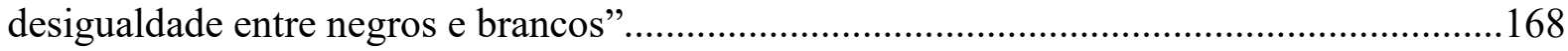

Imagem 24 - "Esta desigualdade tem origem nos tempos da escravidão quando

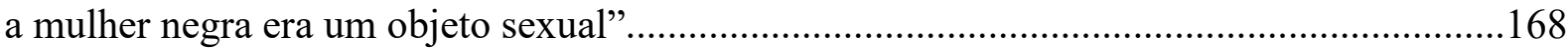

Imagem 25 - “(...) as capas estão frequentemente cheias de mulheres brancas (...)".............169

Imagem 26 - "A escravidão foi abolida oficialmente há muito tempo mas vimos

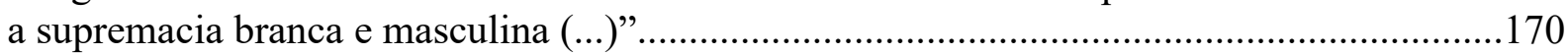

Imagem 27 - “(...) suas experiências são únicas por sofrer dois sistemas de opressão”........171

Imagem 28 - "A vida tem soluções possíveis para o racismo, preconceito e as

desigualdades: é a educação (...)" .....................................................................................172

Imagem 29 - “(...) a única forma de mudar as desigualdades entre mulheres e homens

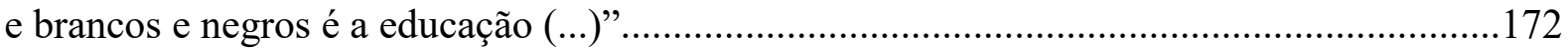

Imagem 30 - "Gostei muito das aulas de francês deste semestre".......................................173

Imagem 31 - “(...) achei interessante como a professora embutiu as discussões com

o francês"......

Imagem 32 - “(...) além de estudarmos francês, aprendemos muito sobre como

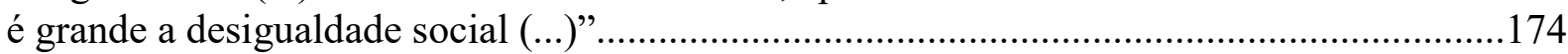

Imagem 33 - "Interessantes para aprender novos conceitos em francês (...)"........................174

Imagem 34 - “(...) diversas oportunidades de realizar discussões sobre vários temas (...)”...174 
Imagem 35 - “(...) além de promover a capacidade crítica dos alunos fez com que treinássemos mais a nossa pronúncia”.

Imagem 36 - “(...) Permitiu olhar o tema em outro ponto de vista que é normalmente retratado pela mídia em geral"..

Imagem 37 - “(...) interessante abordar temas que estão presentes a todo momento na nossa vida (...)"

Imagem 38 - “(...) senti limitado pelas minhas capacidades expressivas em francês (...)”....177 Imagem 39 - "Muito bom a tentativa de me posicionar quanto a tudo isso

em francês (...)"

Imagem 40 - "Foi de imenso ganho pessoal (...)"

Imagem 41 - “(...) aprender sobre como respeitar o próximo é sempre bom”.

Imagem 42 - "Desconstrui esse preconceito e percebi que cor não define nada".

Imagem 43 - "(...) importante para qualquer argumento ou opinião que eu tiver que

formar ao longo da minha vida (...)"

Imagem 44 - “(...) é necessário uma transformação de pensamento".

Imagem 45 - "(...) essas aulas abriram meus olhos para a situação da nossa

sociedade (...)".....

Imagem 46 - Madeleine de Jacques Brel........................................................................211

Imagem 47 - Caso de feminicídio 1

Imagem 48 - Caso de feminicídio 2 


\section{SUMÁRIO}

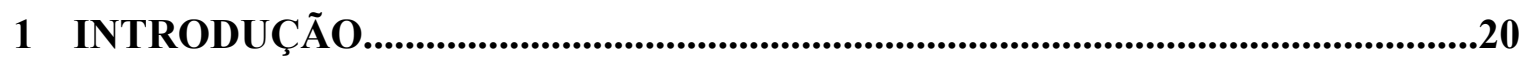

1.1 Motivação para a pesquisa...............................................................................................20

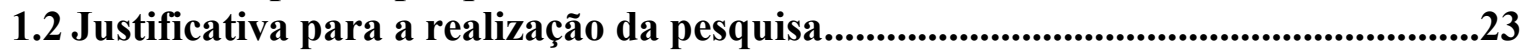

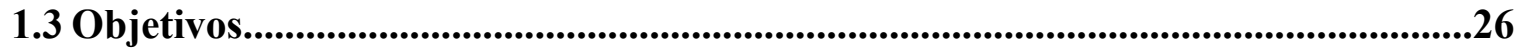

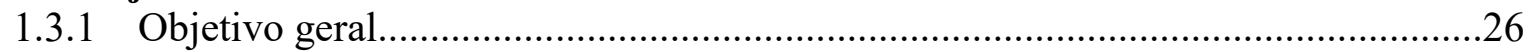

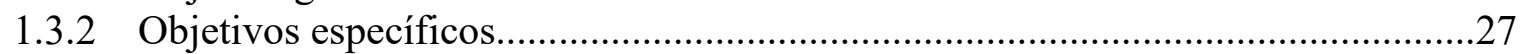

1.4 Perguntas de pesquisa.........................................................................................27

1.5 Roteiro da dissertação..............................................................................................................28

2 REFERENCIAL TEÓRICO.....................................................................................30

2.1 Identidades e ensino-aprendizagem de línguas.....................................................30

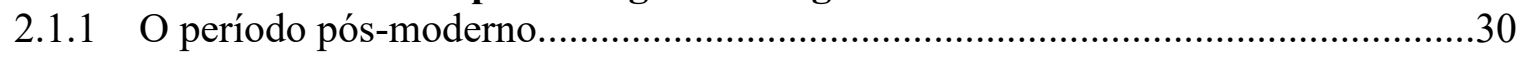

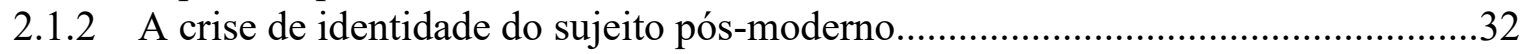

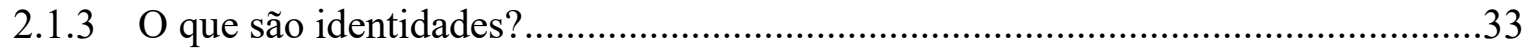

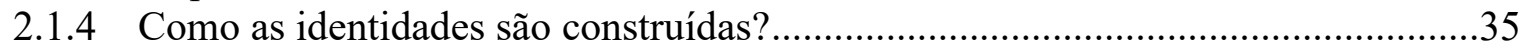

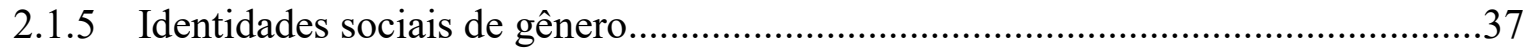

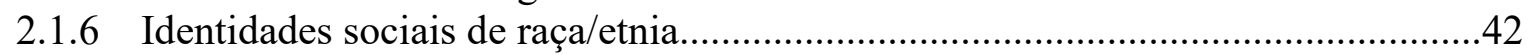

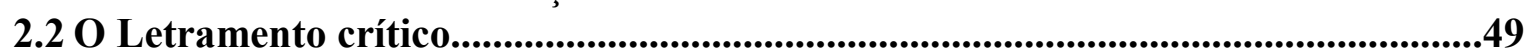

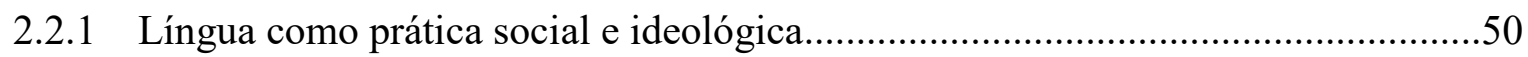

2.2.2 Os aportes de Paulo Freire para o letramento crítico.............................................51

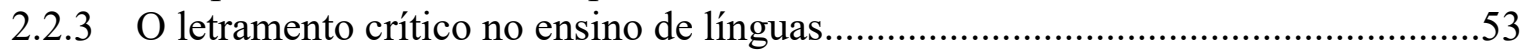

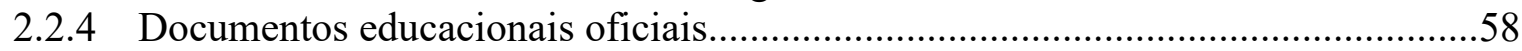

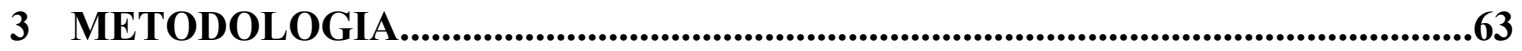

3.1 A pesquisa qualitativa...........................................................................................................63

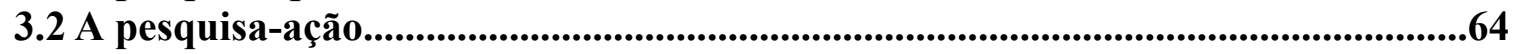

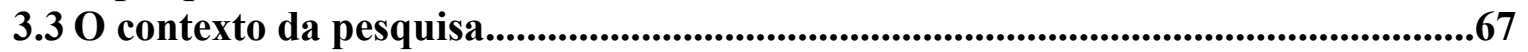

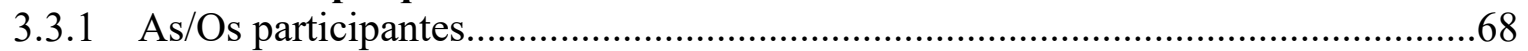

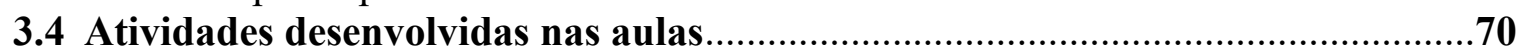

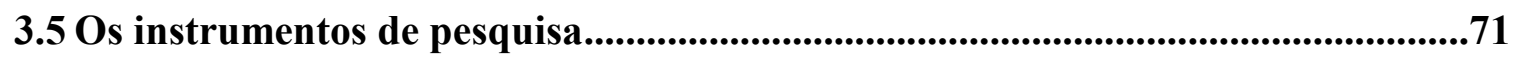

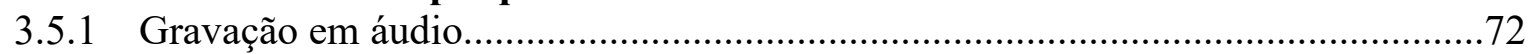

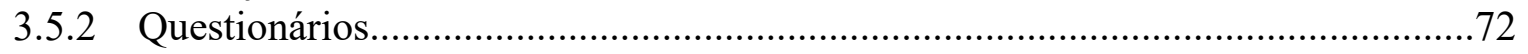

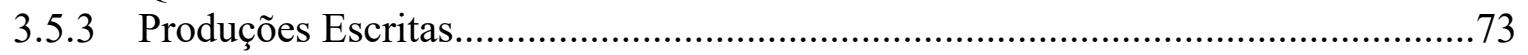

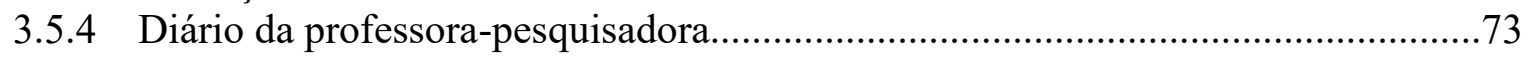

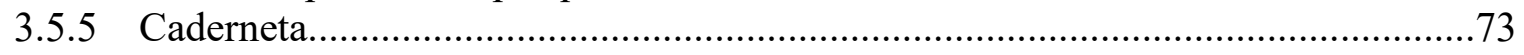

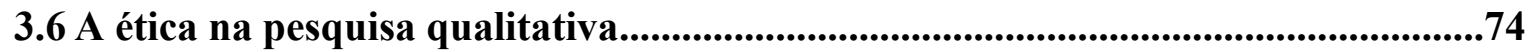

3.7 Os procedimentos para a discussão dos dados.....................................................75

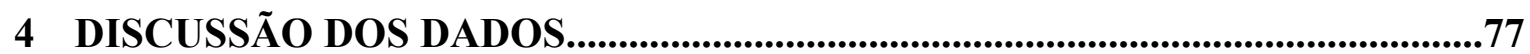

4.1 Discussão das atividades de intervenção e dos questionários das atividades........77

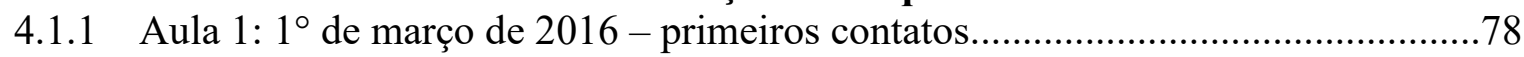




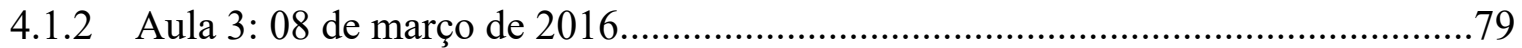

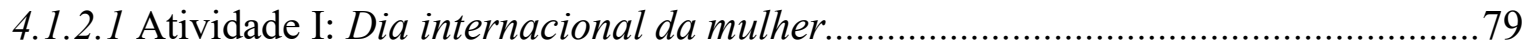

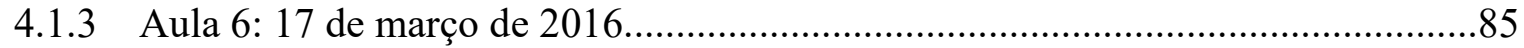

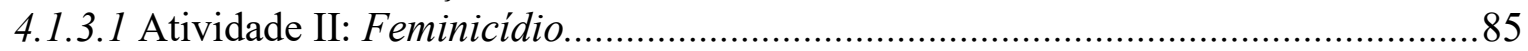

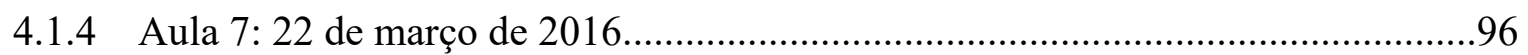

4.1.4.1 Atividade III: Vantagens e desvantagens de ser homem e mulher na sociedade...96

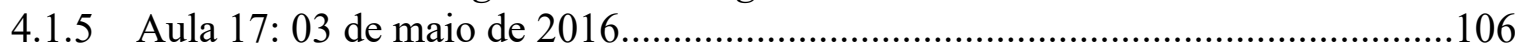

4.1.5.1 Atividade IV: Desigualdades entre homens e mulheres.....................................106

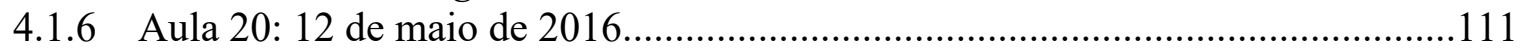

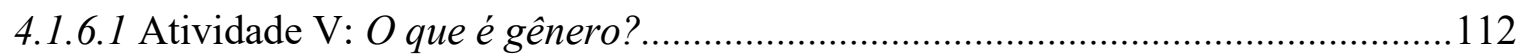

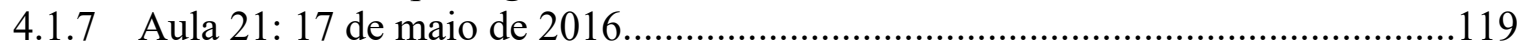

4.1.7.1 Atividade VI: Representações de mulheres brancas e negras..............................120

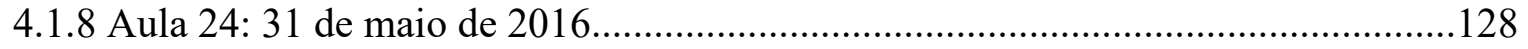

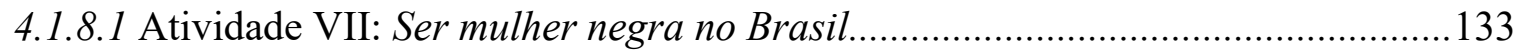

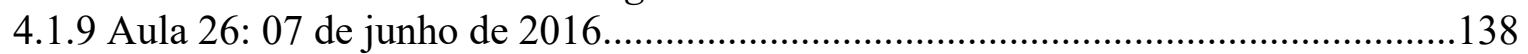

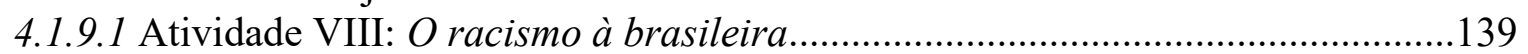

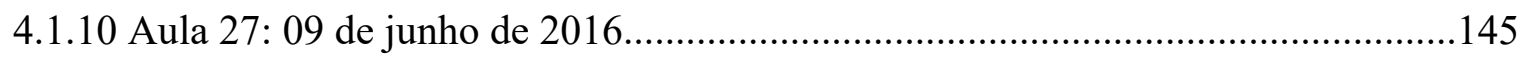

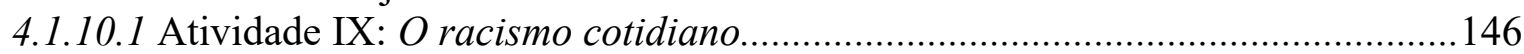

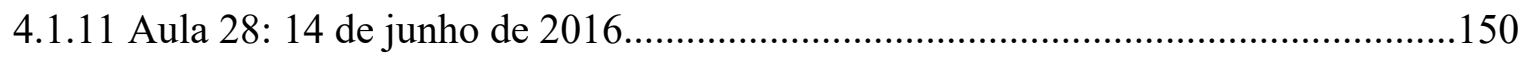

4.1.11.1 Atividade X: A representação da mulher negra nas capas de revista................151

4.2 Discussão das produções escritas................................................................................157

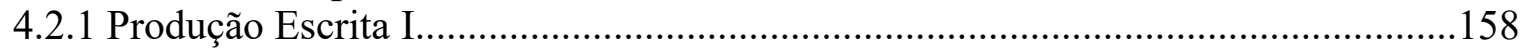

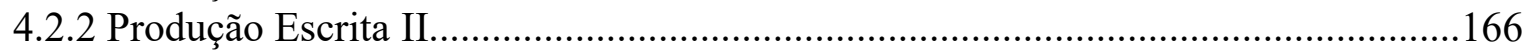

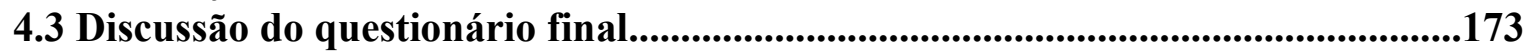

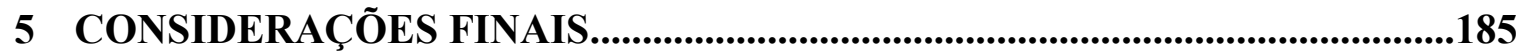

5.1 Retomando as perguntas de pesquisa...............................................................185

5.1.1 Quais as percepções das/os participantes sobre as identidades sociais de gênero e raça/etnia? Como elas/es entendem a dinâmica dessas identidades na sociedade?

5.1.2 Como o letramento crítico propicia interações e abre espaço para problematização e (re)construção de identidades em um contexto de francês como língua adicional? Quais as possibilidades e desafios ao desenvolver esse ensino em sala de aula?

5.1.3 Quais os desdobramentos do letramento crítico na (re)construção das identidades sociais de gênero e raça/etnia, bem como na formação de cidadãs/os críticas/os e reflexivas/os?

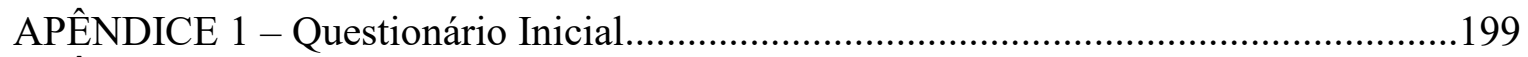

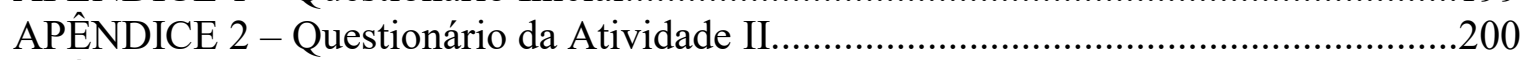

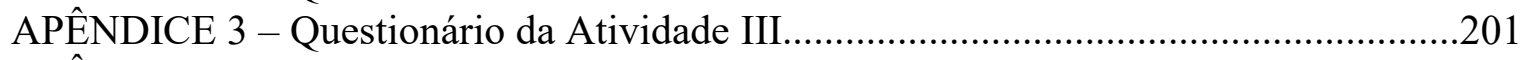

APÊNDICE 4 - Questionário da Atividade IV ............................................................202

APÊNDICE 5 - Questionário das Atividades VI, VII e IX...........................................203

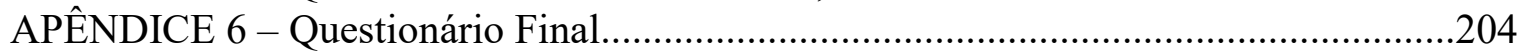




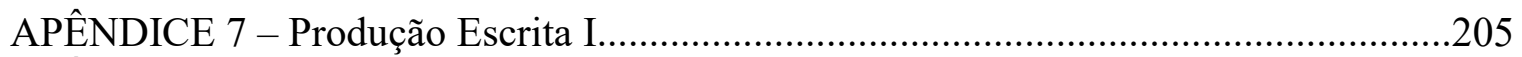

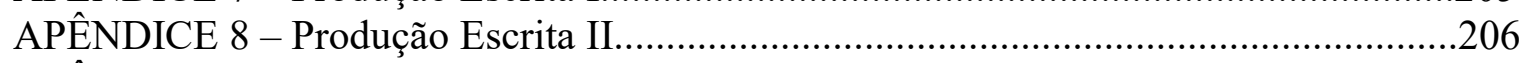

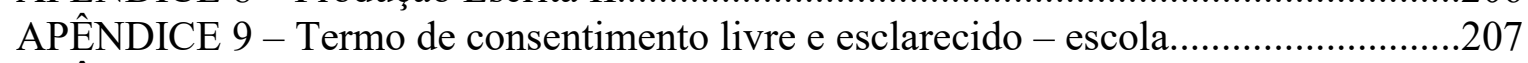

APÊNDICE 10 - Termo de consentimento livre e esclarecido - alunas/os.....................208

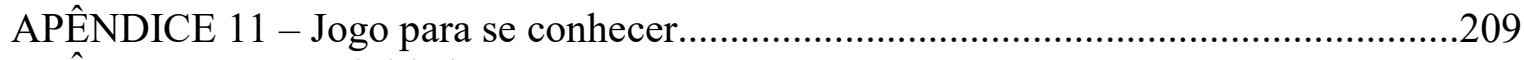

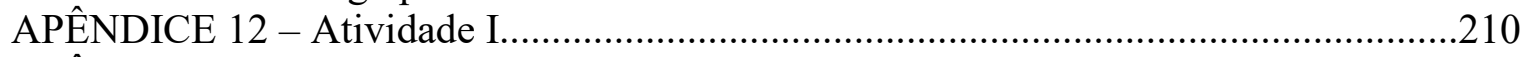

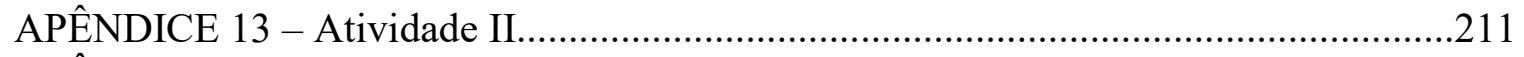

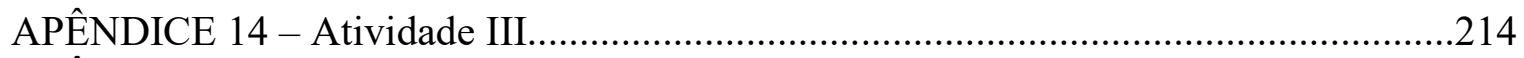

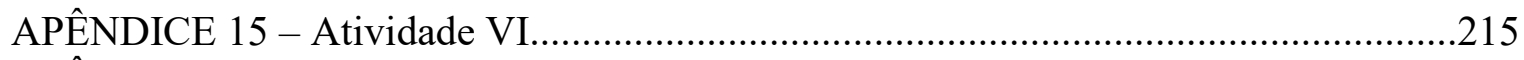

APÊNDICE 16 - Atividade VIII.................................................................. 216 


\section{INTRODUÇÃO}

Esta pesquisa situa-se na área de Linguística Aplicada, mais precisamente dentro da perspectiva crítica de ensino que relaciona o uso da língua com o mundo social envolvendo questões como acessos, hierarquias e relações de poder (PENNYCOOK, 2001, 2006; HOOKS, 2013; MOITA LOPES, 2012; FERREIRA, 2012).

Neste capítulo, apresento, em um primeiro momento, um pouco da minha trajetória profissional que me levou a desenvolver um trabalho dentro da perspectiva crítica de ensino, focando nas identidades sociais de gênero e raça/etnia, bem como a metodologia utilizada. Em seguida, apresento os objetivos e as perguntas que nortearam o desenvolvimento desta pesquisa.

\subsection{Motivação para a pesquisa}

Minha trajetória como professora de língua francesa começou em 2005 quando ingressei no curso de Letras-Francês da Universidade de Brasília (UnB). Minha opção pelo curso veio dos meus estudos de francês realizados no Centro Interescolar de Línguas (CIL) de Sobradinho. O CIL é uma “escola pública de línguas estrangeiras que integra a Educação Básica, ofertando o componente curricular Língua Estrangeira (LE)” (DAMASCO, 2014, p.437). Atualmente, o Distrito Federal conta com 15 unidades de CILs que pertencem à rede pública de ensino oferecendo cursos de inglês, francês, espanhol e, em alguns deles, alemão e japonês. Os cursos são ofertados a alunas/os da rede pública e funcionam nos períodos da manhã, tarde e noite, podendo a/o aluna/o escolher o turno de sua preferência.

No início do curso no CIL, tive uma adaptação difícil, pois meu desejo era estudar inglês. Contudo, não havia vagas suficientes para todas/os as/os alunas/os e foi preciso fazer um sorteio para as duas línguas. Costumo dizer que o francês sempre me escolheu e, graças a essa língua, hoje tenho não apenas uma profissão, mas uma paixão. Sou apaixonada pelo que faço e me sinto cada dia mais motivada a aperfeiçoar minha prática pedagógica. Após quase seis anos no CIL, pude concluir o curso de francês e ingressar na licenciatura do francês e, posteriormente, no curso de Letras-Português da UnB.

No ano de 2006, comecei a lecionar francês em cursos de línguas, o que me permitiu o encontro com a minha profissão. Não fazia ideia de como seria dar aulas e se daria conta das enormes responsabilidades. Surpreendi-me com a dinamicidade que a profissão traz. 
Conhecer pessoas, compartilhar conhecimentos e ter o prazer de ensinar e aprender com minhas/meus alunas/os foi emocionante e primordial para mim. Eu havia descoberto a minha profissão, ficaria feliz em poder fazer aquilo durante toda minha vida.

Chegando ao final da graduação, sentia falta de ter mais contato com a língua. Foi quando tive a oportunidade de trabalhar como professora assistente de língua portuguesa na França. Durante quase um ano, ministrei aulas de português e cultura brasileira para alunas/os do ensino fundamental e médio na cidade de Fontainebleau. Posso dizer que essa experiência foi um divisor de águas na minha vida. Ali, tive a oportunidade de sair dos bancos da escola e viver a língua e um pouco da cultura (que em geral chamamos de) francesa. Além do grande ganho linguístico, a experiência de viver outra cultura foi o que mais me acrescentou como professora e como pessoa. Foi o momento em que eu "saí da minha caverna" para conhecer um pouco mais do mundo. Sem dúvida essa experiência intercultural me possibilitou ter outros olhares para as minhas aulas.

Ao retornar ao Brasil, prestei concurso para fazer parte do quadro efetivo da Secretaria de Estado de Educação do Distrito Federal (SEEDF) como professora de francês. Durante mais de três anos, fui lotada na Aliança Francesa (AF) de Brasília, escola onde esta pesquisa foi realizada. Por se tratar de uma rede de escolas de ensino de francês, pude participar de formações e cursos de didática específicos para professoras/es de francês, o que me ajudou bastante a desenvolver minha prática pedagógica.

É importante ressaltar que a instituição possui, desde 1966, um acordo de cooperação técnica com a SEEDF. Dentro dessa perspectiva, o acordo prevê a oferta de certo número de vagas para estudantes e servidoras/es da SEEDF na instituição. Por outro lado, professoras/es servidoras/es da SEEDF são lotadas/os na escola sem que haja nenhuma troca financeira entre as partes do acordo. O acordo tem ainda caráter de cooperação técnica no qual os professoras/es da SEEDF com habilitação em licenciatura em Francês Língua Estrangeira devem trazer contribuições técnicas ao corpo docente da instituição. Atualmente há três professoras/es servidoras/es da SEEDF que se encontram lotadas/os nessa instituição e aproximadamente 300 alunas/os da SEEDF. Dessa forma, alunas/os da instituição, bem como da SEEDF, compartilham o mesmo espaço no aprendizado da língua francesa.

Apesar dos cursos e formações realizados ao logo desses anos, sentia que ainda tinha muito a aprender sobre o ensino de línguas. De maneira geral, as formações se baseiam na didática da língua em si, em como trabalhar com diferentes documentos em sala de aula, visando ao aprimoramento da língua e o desenvolvimento de habilidades didáticas. Contudo, acreditava que o ensino de línguas poderia ir além da língua pela língua e fazer, de fato, parte 
da vida da/o aluna/o. Essa busca por maior aprofundamento me levou a cursar disciplinas do mestrado na UnB como aluna especial a fim de ter conhecimento de teorias para desenvolver meu projeto de mestrado. Nesse momento, ainda não havia ingressado no mestrado, mas cursava algumas disciplinas do programa para, posteriormente, poder aproveitar os créditos. Nesse período, tivesse acesso a estudos metodológicos que nortearam o desenvolvimento da minha pesquisa. Ademais, pude ler alguns artigos sobre identidades no ensino e aprendizagem de línguas. Por trazer um cunho social, me senti tocada pelas teorias e experiências relatadas pelas/os professoras/es pesquisadoras/es. Tais estudos iam além do ensino do código linguístico, se voltavam para a sociedade, para a vida das/os próprias/os alunas/os, transgrediam as barreiras sociais categorizantes e traziam uma concepção de ensino muito mais humana e útil para nossa sociedade, me levando a desenvolver meu projeto de pesquisa baseado em identidades sociais.

No ano seguinte, ingressei no mestrado no Programa de Pós-Graduação em Linguística Aplicada (PPGLA) da UnB e tive a oportunidade de cursar a disciplina Identidades e ensino-aprendizagem de línguas com a professora Mariana Rosa Mastrella-deAndrade, que veio a ser minha orientadora de pesquisa. Durante um semestre, estudamos as perspectivas teóricas contemporâneas e pós-modernas e suas consequências para as práticas identitárias. Vimos a relação língua/linguagem e identidade e suas implicações para o ensino e aprendizagem de línguas dentro e fora dos contextos educacionais formais. Esses estudos mais aprofundados sobre identidades me levaram a ter contato com textos da perspectiva crítica de línguas e suas concepções para o ensino no mundo contemporâneo. As leituras nessa área me conduziram, por conseguinte, a desenvolver um trabalho de letramento crítico inserido na vida social.

Durante o mestrado, tive acesso a autoras/es que entendem língua como prática social, repleta de ideologias e relações de poder (FAIRCLOUGH, 2008; MOITA LOPES, 2012; NORTON, 2000) e veem no ensino uma possibilidade de transformação social por meio da reflexão crítica da realidade (FREIRE, 2011; PENNYCOOK, 2001, 2006; MOITA LOPES, 2012; FERREIRA, 2006, 2012; TILIO, 2012, 2015a; HOOKS, 2010, 2013), dentre outros.

Essas/es autoras/es concordam que o ensino de línguas deve se voltar para a problematização da realidade injusta e preconceituosa que, por meio da língua, constrói discursos excludentes que oprimem e discriminam outras formas de vida.

Embasada nessas/es autoras/es, busquei desenvolver uma pesquisa que trouxesse impactos não apenas na minha prática pedagógica, mas, sobretudo, na vida das/os alunas/os. Dessa forma, pensei em problematizar questões sociais que tivessem alguma relação com a 
vida das/os alunas/os, com suas próprias vivências, refletindo sobre minhas ações durante esse processo.

$\mathrm{Na}$ seção a seguir, reflito um pouco mais sobre os motivos que me levaram a realizar esta pesquisa voltada para a problematização de identidades sociais na sala de aula de francês.

\subsection{Justificativa para a realização da pesquisa}

Os pressupostos teóricos de uma pedagogia transgressiva questionam discursos hegemônicos que configuram a sociedade em hierarquias e limitam ações nas diversas esferas da sociedade. Essa abordagem de ensino prevê discutir, problematizar e desestabilizar, em sala de aula, temas e questões que envolvem relações de poder, acesso, desigualdade, injustiça e resistência.

Isso implica entender língua como prática social, como uma maneira de agir sobre o mundo e sobre os outros, um modo de representação (FAIRCLOUGH, 2008). A língua constrói identidades sociais, que são múltiplas e fragmentadas (HALL, 2014; SILVA, 2014) e traz em si relações de poder. O poder aqui é entendido não como inexorável, ou seja, ele não existe e é possuído por si só, mas é exercido nas interações humanas que legitimam verdades, regras, crenças, valores de um grupo que dele se beneficiar, desfavorecendo outros (FOUCAULT, 2011).

Nesse sentido, concordo com Moita Lopes (2012, p. 10) quando diz que

o que se deseja como professor(a) de línguas é o engajamento do aluno no discurso com a esperança que [sic] possa usá-lo para fazer escolhas éticas sobre o mundo social que espelhem a possibilidade de refutar qualquer tipo de sofrimento humano.

Nesse excerto, o autor ressalta a relevância da/o professor/a na formação cidadã das/os suas/seus alunas/os que, ao usarem a língua para agir na sociedade, espera-se que optem por discursos em prol da ética, da liberdade, da igualdade e da justiça.

Apesar de ter concluído minhas graduações em Letras-Francês e Português na mesma universidade onde desenvolvi o mestrado, não me lembro de ter cursado nenhuma disciplina que abordasse os múltiplos papéis da/o professor/a, não apenas a/o de línguas, pois, a meu ver, qualquer que seja a área de atuação da/o professor/a, a profissão por si só abarca a função de educador/a, de formador/a de opinião e de crítica/o. A esse respeito, Tilio (2012) assevera que 
o professor precisa ser mais do que um mero instrutor; ele precisa ser um educador, preocupado com questões sociais, culturais e políticas relevantes à vida de seus alunos. O professor precisa ser um intelectual que faz seus alunos pensarem criticamente e lutarem por mudanças quando necessário. (TILIO, 2012, p. 140).

Tendo como base o excerto acima, acredito que a/o professor/a tem o papel de educar, de formar cidadãs/os críticas/os e reflexivas/os. Assim como afirma Freire (2011), penso que, enquanto educador/a, a/o professor/a deve proporcionar, com as/os educandas/os, as condições para desenvolver o pensamento autêntico por meio de uma conscientização da realidade opressora.

Com base nas teorias identitárias e críticas do ensino de línguas, pude refletir sobre a minha prática pedagógica e percebi que ela não envolvia problematizar as relações de poder e discutir questões sociais e políticas em sala de aula, sobretudo as que envolviam a vida das/os alunas/os. Após ter acesso a essas teorias, decidi desenvolver uma pesquisa ligada a questões sociais, estimulando a reflexão crítica das/os minhas/meus alunas/os e refletindo sobre a minha própria prática. Por visar, em última análise, ao exercício da palavra, concordo com Moita Lopes (2012) ao dizer que a sala de aula de línguas permite que se trate de qualquer tema, pois usamos a língua para proferir discursos de diferentes temáticas sociais. Dentre os diversos temas possíveis, tive acesso, primeiramente, aos textos da Profa. Dra. Aparecida de Jesus Ferreira $(2006,2012,2015)$ a respeito de raça/etnia. Seus textos são profundos, tocantes e se relevam de imensa sensibilidade para tratar de um tema sensível e, muitas vezes, silenciado nas escolas e na sociedade. Em suas obras, me adentrava nas profundezas da questão racial, me dando conta do quanto o racismo ainda está enraizado e, muitas vezes, camuflado nas nossas práticas sociais.

Além disso, o tema gênero vem ganhando espaço nas discussões escolares no Brasil desde que o Exame Nacional do Ensino Médio (ENEM) de 2015 abordou uma questão sobre feminismo com a célebre frase de Simone de Beauvoir (2009, p. 9) "ninguém nasce mulher: torna-se mulher". Nessa formulação, a autora busca rejeitar qualquer naturalização sobre o comportamento feminino. Além disso, a prova trouxe o tema: "A persistência da violência contra a mulher na sociedade brasileira" como proposta de redação. Tal evento foi alvo dos mais diversos comentários em todas as esferas da sociedade. No dia posterior às provas, era possível ler nas redes sociais comentários a favor e radicalmente contra a proposta do exame. As/Os que eram a favor comemoravam a inclusão, em provas nacionais, de um tema tão 
sensível da sociedade brasileira que merece atenção e reflexão, devido ao grande número de agressões à mulher que ainda persistem no Brasil. Por outro lado, as/os que se posicionaram contra depreciaram a frase de Beauvoir ao fazer claramente a confusão entre o sexo e o gênero de uma pessoa. Além disso, negligenciaram a abrangência e o impacto da violência contra a mulher na sociedade, afirmando não ser esse o papel da educação, indo de encontro aos próprios documentos educacionais oficiais (BRASIL, 1998; BRASIL, 2006) que preveem discutir e problematizar questões sociais na escola. Esses fatos me levaram a incluir o tema gênero na minha pesquisa, refletindo sobre as opressões e desigualdades advindas da sua construção.

Ademais, apesar de previstos pelos documentos oficiais da educação já há algum tempo como os Parâmetros Curriculares Nacionais (PCNs) de 1998 e as Organizações Curriculares para o Ensino Médio (OCEMs) de 2006, como também mais recentemente pela Base Nacional Comum Curricular (BNCC) de abril de 2016, documento da Educação Básica do país que está sendo redigido por diferentes atores do contexto educacional e que se encontra, em sua fase preliminar, na segunda versão - esses temas ainda não se encontram devidamente inseridos nas salas de aula. Temas como esses são desafiadores para nós professoras/es de línguas, pois nos colocam por vezes diante do inesperado e exigem de nós uma reação, uma posição política contra as diversas formas de preconceito e discriminação que possam surgir em sala. Abordar esses temas nos demanda ainda conhecimento de mundo para lidar com as diferentes situações, além de conhecimentos teóricos capazes de embasar nossas reflexões e atitudes.

Vale ressaltar que esta pesquisa se deu, ainda, no contexto do movimento Escola sem Partido, criado em 2004 com o objetivo de combater o que consideram "doutrinação ideológica" nas escolas de educação básica. Tal proposta busca evitar o pensamento crítico das/os alunas/os sobre temas que dizem respeito às suas próprias vidas pessoais como questões de gênero e raça/etnia, por exemplo. Por meio de um discurso conservador e autoritário, busca-se uma neutralidade e imparcialidade que se torna impossível uma vez que falamos sempre de um contexto histórico e social específico. Tal proposta vai contra a própria Lei de Diretrizes e Bases da Educação que prevê em seu artigo $3^{\circ}$ incisos II, III e IV a "liberdade de aprender, ensinar, pesquisar e divulgar a cultura, o pensamento, a arte e o saber", bem como o "pluralismo de ideias e de concepções pedagógicas" além do "respeito à liberdade e apreço à tolerância" (BRASIL, 2014).

A sala de aula de língua francesa, como em outras disciplinas, é um lugar de construção de identidades sociais, o que nos dá a oportunidade, como professoras/es, de 
discutir temas que envolvam a construção dessas identidades, problematizando-as com vistas à transformação social.

Pesquisas contemporâneas na área da Linguística Aplicada (LA) têm contemplado o lado social envolvido na prática do ensino e aprendizagem de línguas, mostrando que não é mais possível desvincular o aprendizado de uma língua de quem a aprende (MASTRELLA, 2007; AZEVEDO, 2010; FERREIRA, 2011; FERNANDES, 2012). Partindo dessa perspectiva, tornam-se relevantes estudos com foco em identidades no ensino de línguas, pois, na visão de Mastrella-de-Andrade (2013), eles possibilitam maior acesso aos tipos de relações sociais que se estabelecem na sala de aula, bem como aos discursos que posicionam os sujeitos e as interações que constroem e (re)negociam identidades conflitantes.

Com base nesse ângulo, abordo, nesta pesquisa, as identidades de gênero e raça/etnia e suas intersecções, buscando compreender como as/os alunas/os entendem a dinâmica dessas identidades na sociedade, como elas/es percebem as relações de poder entre elas, as desigualdades de oportunidades de acesso, as hierarquias que são construídas, pela linguagem, para limitar ações das ditas minorias nas práticas sociais. Para tanto, lanço mão da metodologia da pesquisa-ação (BARBIER, 2007; FRANCO, 2005), que busca desenvolver uma prática crítico-reflexiva com a participação de todas/os as/os envolvidas/os no processo da pesquisa, apresentando ainda caráter intervencionista de transformação social. Este trabalho visa refletir sobre discursos sexistas e racistas que circulam na nossa sociedade, como também nas sociedades de língua francesa, em prol da construção de discursos mais libertadores, humanos e igualitários.

\subsection{Objetivos}

\subsubsection{Objetivo geral}

Com a presente pesquisa, busco investigar como o letramento crítico abre espaço para (re)construção de identidades sociais de gênero e raça/etnia com vistas à formação cidadã nas aulas de francês língua adicional ${ }^{1}$.

\footnotetext{
${ }^{1}$ Segundo Nicolaides e Tilio (2013, p. 285) “o termo língua adicional tem sido adotado por alguns estudiosos da área, por entender que melhor se encaixa nas novas tendências de uma LA que vê o ensino de línguas de forma crítica e entende o usuário da língua não como um estranho à língua. [...] $\mathrm{O}$ termo língua adicional se aplica a todas às línguas aprendidas, exceto, é claro, à primeira língua do falante. [...] O termo língua estrangeira, no entanto, parece sugerir que a língua seja estranha, exótica, ou, talvez, excludente todas essas conotações indesejáveis. Nossa opção pelo termo adicional ratifica nossa crença de que línguas adicionais não são inferiores, superiores, ou mesmo substitutivas da primeira língua”. Assim, neste trabalho, utilizo o termo língua adicional por entender que a língua não é estrangeira à/ao aluna/o. Aqui recorro à Almeida Filho (2013) quando declara que o termo língua estrangeira apresenta um conceito complexo, sobre o qual a/o professor/a precisa refletir.
} 


\subsubsection{Objetivos específicos}

A partir do objetivo geral, foram formulados os objetivos específicos seguintes:

a) Analisar as percepções das/os participantes sobre as identidades sociais de gênero e raça/etnia, bem como a maneira como elas/es entendem a dinâmica dessas identidades na sociedade;

b) Analisar como o letramento crítico pode propiciar interações e favorecer a problematização e a (re)construção de identidades no contexto de francês como língua adicional, bem como verificar as possibilidades e os desafios ao se trabalhar com esse ensino em sala de aula;

c) Analisar os desdobramentos do letramento crítico para a (re)construção de identidades sociais de gênero e raça/etnia, bem como para a formação de cidadãs/os críticas/os e reflexivas $/ \mathrm{os}^{2}$.

\subsection{Perguntas de pesquisa}

Diante de estudos feitos na LA, mais especificamente na perspectiva crítica da linguagem, e da minha experiência como professora de francês, surgiu o interesse em realizar a pesquisa, buscando discutir possíveis respostas para as seguintes perguntas de pesquisa:

a) Quais as percepções das/os participantes sobre as identidades sociais de gênero e raça/etnia? Como elas/es entendem a dinâmica dessas identidades na sociedade?

b) Como o letramento crítico propicia interações e abre espaço para problematização e (re)construção de identidades em um contexto de francês como língua adicional? Quais as possibilidades e os desafios ao desenvolver esse ensino em sala de aula?

Para o autor, ele pode significar a língua da/o outra/o, ou de outras/os, algo que não nos pertence [...] (ALMEIDA FILHO, 2013). Assim, a língua adicional, por não ser estrangeira, pertence à/ao aluna/o, que dela se apropria para expressar suas emoções e sentimentos, vindo, portanto, somar-se às demais.

${ }^{2}$ Nesta pesquisa, não há o interesse em investigar como as identidades das/os participantes são (re)construídas, mas sim suas visões sobre essas identidades. 
c) Quais os desdobramentos do letramento crítico para a (re)construção de identidades sociais de gênero e raça/etnia, bem como para a formação de cidadãs/os críticas/os e reflexivas/os?

Ao longo da pesquisa e da discussão dos dados, tendo em vista os desafios por mim encontrados, entendi que minha identidade de professora também estava sendo colocada em processo de reconstrução. Assim, os dados sinalizaram para mim a proposição de mais uma pergunta de pesquisa para a qual eles apresentavam possibilidades de problematização:

d) De que maneira práticas de letramento crítico em aulas de francês língua adicional podem (re)construir identidades docentes?

\subsection{Organização da dissertação}

Esta dissertação está dividida em cinco capítulos: o primeiro corresponde à introdução, o segundo ao referencial teórico, o terceiro à metodologia, o quarto à discussão dos dados e o quinto às considerações finais.

No capítulo 1, apresentei os caminhos percorridos para o desenvolvimento da pesquisa. Para tanto, trouxe a motivação e a justificativa para a pesquisa, bem como os objetivos e as perguntas de pesquisa que nortearam este estudo.

No capítulo 2, faço, em um primeiro momento, uma relação entre identidades e o ensino e aprendizagem de línguas perpassando por questões relacionadas ao período pósmoderno, à construção das identidades na e pela linguagem e suas implicações na sala de aula de línguas, além de abordar a construção das identidades sociais de gênero e raça/etnia. Posteriormente, passo a refletir sobre o letramento crítico na aula de línguas. Para tanto, trago os aportes de Paulo Freire para essa perspectiva de ensino e apresento o meu entendimento de língua como prática social e ideológica. Em seguida, abordo como o trabalho com identidades sociais está previsto nos documentos educacionais oficiais.

No capítulo 3, apresento a metodologia adotada neste estudo abordando o contexto da pesquisa, as/os participantes, as atividades desenvolvidas em sala e os instrumentos utilizados para geração dos dados.

No capítulo 4, faço a discussão dos dados, apresentando, em um primeiro momento, os dados gerados pelas atividades de intervenção, bem como pelos questionários de cada 
atividade. Em seguida, reflito sobre os dados das produções escritas. Posteriormente, discuto sobre os dados gerados no questionário final.

Finalmente, no capítulo 5 , respondo às perguntas de pesquisa que nortearam este estudo e faço algumas reflexões finais. 


\section{REFERÊNCIAL TEÓRICO}

\subsection{Identidades e ensino-aprendizagem de línguas}

Falar em identidades no ensino e na aprendizagem de línguas hoje significa, inevitavelmente, falar de um sujeito real com crenças e valores. E é exatamente na língua que expressamos a nossa forma de ver o mundo, a maneira como damos sentido a tudo que nos cerca. A esse respeito, Norton e Toohey (2001) afirmam que a aprendizagem de línguas traz em si questões relacionadas a identidades, pois aprender uma nova língua vai muito além do aprendizado do código linguístico em si, podendo incluir o envolvimento em novas práticas socioculturais.

Neste capítulo, abordo, em um primeiro momento, o conceito de globalização e seus efeitos na vida das pessoas levando à crise de identidades no período pós-moderno. Para tanto, me baseio em autores como Giddens (1991), Bauman (2001) e Hall (2014). Posteriormente, passo a falar sobre a maneira como a linguagem constrói as identidades sociais me baseando em Woodward (2014), Silva (2014), Norton (2000), Butler (1999), entre outros. Em seguida, apresento as implicações das identidades no ensino e aprendizagem de línguas, relatando, mais especificamente, as identidades de gênero e raça/etnia, que são o foco desta pesquisa. Tais seções se baseiam em autores como Ferreira; Brigolla (2013), Mastrellade-Andrade (2010), Louro (2003, 2008), Auad (2003), Scott (1995), Telles (2003), Gomes (2005a, 2005b), Ferreira (2006, 2012), Munanga (2005), Oliveira (2006), dentre outros teóricos que se voltam para essa temática.

\subsubsection{O período pós-moderno}

O tempo presente tem sido marcado por mudanças profundas no campo social, econômico e político, sobretudo com o advento da globalização e da estrutura da sociedade capitalista. Giddens (1991, p. 69) define globalização como "a intensificação das relações sociais em escala mundial, que ligam localidades distantes de tal maneira que acontecimentos locais são modelados por eventos ocorrendo a muitas milhas de distância e vice-versa".

Com a chegada de novas tecnologias, como a internet, nossa maneira de nos relacionarmos com as pessoas e com o mundo vem mudando. Através dela, as informações circulam rapidamente nas redes sociais e mudam cotidianamente. Eventos ocorridos do outro 
lado do mundo podem ser acompanhados quase que instantaneamente em diferentes partes do planeta, trazendo impactos para nossas vidas. Da mesma forma, é possível nos conectarmos com pessoas de outros países, trabalhar ou estudar sem estar devidamente "presente" naquele lugar. Giddens (1991) concebe essas mudanças como descontinuidade e separação entre o tempo, o espaço e o lugar.

Bauman (2001, p. 8) nomeia esse período de modernidade líquida, pois, diferentemente dos sólidos, os fluidos são "leves", não tem forma concreta, "não fixam o espaço nem prendem o tempo". O autor afirma que, na modernidade imediata, antigas configurações e tradições foram "derretidas" para que outras pudessem ser refeitas e moldadas.

Nas palavras de Mastrella-de-Andrade (2010, p. 110), com base em autores como Santos (1999) e Hall (2014), a modernidade concebe o sujeito como "indivíduo soberano, racional, livre, autônomo, centrado, características recorrentes do domínio da razão e da racionalidade do movimento humanista". Contudo, a modernidade não dá conta de responder a todos os problemas nem de superar as injustiças sociais; ela falha na sua tentativa de controlar as diversas variáveis da vida social, política e econômica.

O período atual, conhecido como pós-modernidade ${ }^{3}$, não se caracteriza como um momento único. Como nos lembra Giroux (1999), ele se configura por várias perspectivas nos campos políticos, estéticos e epistemológicos. Para o autor, o pensamento pós-moderno nega a totalidade da razão, as culturas de fronteiras e o sujeito humanista, indo contra as generalizações e primando pela legitimidade dos eventos particulares da vida social.

$\mathrm{Na}$ pós-modernidade, o sujeito é descentralizado, fragmentado e composto por múltiplas identidades, muitas vezes contraditórias (HALL, 2014) e isso então traz inúmeras implicações para o ensino e aprendizagem de línguas no que diz respeito às questões de língua, poder e identidades (MASTRELLA-DE-ANDRADE, 2010). Como consequência, outra característica da pós-modernidade, apontada pela autora, diz respeito à maneira como nós professoras/es concebemos os sujeitos das salas de aula, ou seja, as identidades de professoras/es e alunas/os e ainda a relevância de entendermos a sala de aula não como neutra, mas como espaço de construção de identidades, onde os diversos discursos, construídos em relações desiguais de poder, nos constituem como sujeitos.

\footnotetext{
${ }^{3}$ Este não é um termo consensual entre os autores, estou seguindo, neste trabalho, a terminologia adotada por Santos (1999).
} 
Tendo em vista o contexto da sociedade pós-moderna, repleta de injustiças sociais que ainda negam acessos a grande parte da população local e global, torna-se primordial trabalhar questões identitárias no intuito de desnaturalizar e problematizar discursos que ditam verdades absolutas sobre o que é "normal" na sala de aula e na sociedade.

\subsubsection{A crise de identidade do sujeito pós-moderno}

Como visto anteriormente, a sociedade atual é marcada por inúmeras transformações sociais advindas da globalização, que trouxe consigo um novo ritmo de vida para as pessoas. A troca de informação se tornou mais rápida com a internet, mudando as características da vida contemporânea. Pessoas do mundo inteiro estão em contato constante, o que implica em consequências para as suas identidades pessoais.

Em vista disso, segundo Hall (2014), somos sujeitos fragmentados, compostos de várias identidades, por vezes contraditórias ou não resolvidas; o autor então fala não de uma visão de sujeito unificado como antes. Woodward (2014) também ressalta que a vida complexa da modernidade exige que assumamos diferentes identidades que podem, contudo, estar em conflito "quando aquilo que é exigido por uma identidade interfere com as exigências de uma outra" (WOODWARD, 2014, p. 32), situação que contribui para ilustrar a a chamada "crise de identidade" na pós-modernidade.

A fim de melhor compreender o processo de transformação de identidades ocorrido ao longo dos anos, Hall (2014), traz três concepções de identidades de sujeito: a) sujeito do Iluminismo, b) sujeito sociológico e c) sujeito pós-moderno. A primeira concebe o sujeito como ser centrado, unificado e dotado de razão. A segunda traz o sujeito sociológico, cuja identidade é formada na sua interação com a sociedade e sendo modificado por ela. No entanto, o sujeito ainda tem um núcleo ou uma essência interior. Finalmente, o sujeito pósmoderno não tem identidade fixa ou estável, ele é constantemente modificado e se caracteriza pelo seu deslocamento, ou seja, ele não possui um centro, mas vários centros, várias identidades, instáveis e muitas vezes contraditórias. Segundo Hall (2014), tal situação se deve ao fato de que, no mundo pós-moderno, o sujeito é confrontado com múltiplas identidades cambiantes, podendo se identificar com cada uma delas, mesmo que temporariamente.

De acordo com Woodward (2014), a globalização acelera o processo de migração, trazendo impactos tanto sobre o país de origem quanto sobre o país de destino. Motivadas por necessidades econômicas, as pessoas se espalham, remodelando as sociedades e a política ao redor do mundo, como pode ser visto em muitas cidades europeias que apresentam 
comunidades e culturas cada vez mais diversificadas. Além disso, a migração produz identidades plurais e contestadas em meio ao contexto global de grandes desigualdades sociais.

A globalização tem trazido impactos não apenas na escala global, mas também nos níveis pessoais, como, por exemplo, mudanças na estrutura de classe social. Um dos impactos faz referência ao que Laclau (1990 apud Woodward 2014, p. 30) chamou de deslocamento, ou seja, a sociedade não apresenta um centro determinado, mas vários centros. Na opinião do autor, um dos centros a ser deslocado foi o da classe social enquanto determinante de todas as outras relações sociais, como a categoria "mestra" descrita nas análises marxistas da estrutura social. O autor nega o paradigma marxista que vê a classe social como a única força determinante e totalizante que molda todas as relações sociais, e diz haver uma multiplicidade de centros, não sendo mais possível argumentar que a emancipação social esteja nas mãos de uma única classe. Segundo o autor, essas implicações são positivas, já que novas identidades podem emergir e novos sujeitos podem se expressar de diferentes lugares. Assim, as afiliações baseadas em classe, tais como sindicatos operários, exemplifica o autor, dão lugar a conflitos sociais baseados no gênero, na raça, na etnia e na sexualidade.

Dessa forma, é possível afirmar que o sujeito pós-moderno está vivendo uma crise de identidade nos níveis globais, locais, pessoais e políticos. Nesse contexto, as identidades tradicionais dão espaço a novas identidades instáveis e contraditórias que estão presentes nos sujeitos, descentralizando-os continuamente. Mas, afinal, o que vem a ser identidade? Como ela é construída? Nas seções a seguir abordo essas questões.

\subsubsection{O que são identidades?}

Nesta seção, abordarei as definições de identidades sob a perspectiva de diferentes autores a fim de traçar um panorama teórico sobre a maneira como compreendo o construto.

Para Woodward (2014), as posições que assumimos na sociedade e com as quais nos identificamos constituem nossas identidades. Elas são construídas no interior dos discursos, por meio da linguagem e das representações feitas a partir dos sistemas simbólicos. Segundo a autora, a identidade é relacional, ou seja, para existir ela depende de algo que está fora dela: a diferença. Sendo assim, a construção da identidade é tanto simbólica quanto social.

Norton (2000, p. 5) percebe a identidade "em referência a como uma pessoa entende sua relação com o mundo social, como essa relação é construída através do tempo e do espaço 
e como a pessoa entende suas possibilidades para o futuro" ${ }^{4}$. Ou seja, a maneira como a pessoa se vê e é vista no mundo, histórica e socialmente, interfere na sua forma de perceber a realidade e de agir sobre ela e, consequentemente, nas suas perspectivas para o futuro. Freire (2011) corrobora tal ideia ao dizer que nossa forma de atuar no mundo advém da maneira como nos percebemos inseridas/os nele. Em outras palavras, nossos pensamentos, ações e perspectivas são baseadas nas nossas posições sociais, ou seja, em nossas identidades.

Isso nos leva a entender a formação de diferentes grupos sociais que compartilham visões de mundo e experiências de vida semelhantes devido às suas afinidades identitárias. Nesse sentido, Bauman (2005) afirma que a identidade está ligada à ideia de pertencimento, ou seja, de fazer parte de um ou outro grupo na sociedade. A identidade, portanto, não tem rigidez, ela não é fixa como uma rocha, ou seja, ela não é a mesma para toda a vida. Para o autor, ela é negociável e revogável. As decisões do indivíduo, sua forma de agir, os caminhos que ele percorre são relevantes tanto para o pertencimento quanto para a identidade.

Com base nisso, entendo que somos sujeitos de múltiplas identidades que correspondem aos papéis que assumimos na sociedade. A maneira como nos vemos deve ser entendida dentro do mundo social, posto que a noção de quem somos não é algo individual, não é baseada apenas em nossas opiniões. Nossas identidades são construídas através do tempo e do espaço, elas têm uma relação intrínseca com o contexto social, uma vez que somos seres históricos e sociais. Assim, quem eu sou hoje depende da forma como eu me vejo e sou vista pelas pessoas nos diferentes espaços sociais e isso tem influência nas minhas perspectivas para o futuro, pois o que eu sou e como sou vista pode influenciar naquilo que posso ser, fazer ou ter acesso.

Ao dizer que elas são construídas na e pela língua, no interior dos discursos, estamos revelando o caráter instável das identidades. Posso proferir um discurso a favor de algo hoje, me fazendo ter o sentimento de pertencimento a um determinado grupo da sociedade e, em outro momento, com outras leituras e reflexões, adentrando outras práticas discursivas, posso lançar mão de outros discursos para resistir e ir contra, levando a me sentir parte de outros grupos. Logo, as identidades são instáveis e temporárias, podendo ser reconstruídas por meio de novos discursos.

Isso se torna relevante para os contextos de ensino de línguas, uma vez que, enquanto educadores, podemos problematizar e reconstruir discursos sobre identidades em sala de aula.

\footnotetext{
4 Tradução de: "to reference how a person understands his or her relationship to the world, how that relationship is constructed across time and space, and how the person understands possibilities for the future”. As traduções feitas neste trabalho são de minha autoria.
} 
Uma vez que elas não são fixas, é possível desconstruí-las por meio do diálogo e da conscientização crítica da realidade em prol de uma sociedade mais justa (SILVA, 2014).

Adiante, passo a refletir sobre a maneira como as identidades são construídas.

\subsubsection{Como as identidades são construídas?}

Como sabemos, a língua traz consigo aspectos sociais de como uma determinada sociedade compreende e interpreta o mundo. É na língua e por meio dela que as identidades e diferenças são construídas dentro de um contexto social e discursivo por meio das relações e interações. Logo, falar em identidades implica falar em diferenças, pois, o que "somos" depende intrinsecamente daquilo que "não somos". Porém a identidade não é o oposto da diferença. Elas são interdependentes, pois a identidade depende da diferença e é estabelecida a partir dela (SILVA, 2014; WOODWARD, 2014).

Assim, as identidades são formadas por meio das diferenças. Segundo Silva (2014), a identidade e a diferença são construídas ativamente dentro das relações culturais e sociais. $\mathrm{O}$ autor observa que a afirmação da identidade e da diferença implica sempre incluir e excluir; logo, a identidade está ligada a uma forte separação entre "nós" e “eles", estando constantemente ligada a choques e conflitos de interesse e de poder. De acordo com Silva (2014, p. 82), a própria distinção entre os pronomes "nós" e "eles" não se dá por uma questão simplesmente gramatical, mas são "evidentes indicadores de posições-de-sujeito fortemente marcadas por relações de poder".

Nas reflexões do mesmo autor,

elas não são simplesmente definidas; elas são impostas. Elas não convivem harmoniosamente lado a lado, em um campo sem hierarquias; elas são disputadas. [...] A identidade e a diferença não são, nunca, inocentes. (SILVA, 2014, p. 81).

E essa disputa envolve conflitos de interesses e de poder além de uma busca mais ampla por recursos materiais e simbólicos (BOURDIEU, 1994). ${ }^{5}$

Assim, tendo em vista que identidades e diferenças são produzidas na e pela língua e que são não apenas construídas, mas disputadas, elas são construídas também em e por meio de relações de poder. Quanto maiores os recursos materiais e simbólicos de uma pessoa,

\footnotetext{
${ }^{5}$ Ao fazer uso das metáforas econômicas de Bourdieu, Mastrella (2007) retrata que os recursos materiais podem ser entendidos como capitais, bens financeiros etc. Já os recursos simbólicos envolvem acessos a relacionamentos, educação, como o aprendizado da língua francesa, por exemplo.
} 
maior será sua possibilidade de exercício de poder. Quanto mais perto da "norma", das identidades prestigiadas: homem, branco, rico, heterossexual etc., maior o seu poder. Da mesma forma, tudo o que se afasta daquilo que é considerado "normal" e "bom" na sociedade se aproxima do que é diferente, logo, é menos valorizado.

Para Butler (1999), as identidades são construídas por meio do caráter performativo da linguagem que prevê que o poder da realização do ato de fala na produção de identidades está na sua incessante repetição. Para a autora, a eficácia produtiva dos enunciados faz parte de uma historicidade condensada, ou seja, um conjunto de práticas discursivas acumuladas historicamente e que sobrevivem devido a sua constante repetição na e pela linguagem. Daí o seu poder para produzir identidades.

O caráter performativo da linguagem prevê que, ao proferir discursos sobre alguém, não estamos apenas descrevendo uma pessoa, mas agindo sobre ela. E, ao proferi-los repetidas vezes, ao longo do tempo e do espaço, estamos reafirmando os valores neles encontrados. Historicamente, tais discursos passam a ganhar status de verdade por serem reconhecidos socialmente. Isso se dá devido à historicidade condensada da qual os discursos fazem parte.

A esse respeito, Silva (2014, p. 93) observa que,

em geral, ao dizer algo sobre certas características identitárias de algum grupo cultural, achamos que estamos simplesmente descrevendo uma situação existente, um 'fato' do mundo social. O que esquecemos é que aquilo que dizemos faz parte de uma rede mais ampla de atos lingüísticos que, em seu conjunto, contribui para definir ou reforçar a identidade que supostamente apenas estamos descrevendo. Assim, por exemplo, quando utilizamos uma palavra racista como 'negrão' para nos referir a uma pessoa negra do sexo masculino, não estamos simplesmente fazendo uma descrição sobre a cor de uma pessoa. Estamos, na verdade, inserindo-nos em um sistema lingüístico mais amplo que contribui para reforçar a negatividade atribuída à identidade 'negra'.

Contudo, Butler (1999) afirma que tal repetição pode ser interrompida e contestada para a produção de novas identidades. Daí a importância de que posições binárias (branca/o/negra/o, homem/mulher, por exemplo), sejam questionadas, pois elas buscam normalizar e estabelecer o que deve ser considerado “normal". Segundo Silva (2014),

normalizar significa eleger - arbitrariamente - uma identidade específica como o parâmetro em relação ao qual as outras identidades são avaliadas e hierarquizadas. Normalizar significa atribuir a essa identidade todas as características positivas possíveis, em relação às quais as outras identidades só podem ser avaliadas de forma 
negativa. A identidade normal é tal que ela nem sequer é vista como uma identidade, mas simplesmente como a identidade. (SILVA, 2014, p. 83).

Assim, a identidade só é possível graças à diferença que a constitui. Somos construídas/os pelo olhar do outro e, por meio desse olhar, podemos perceber as diferenças que nos constituem e definem quem somos. Porém, muitas vezes, a diferença é vista como negativa, como desvio das regras, do que é considerado "normal" na sociedade. Tendo em vista que somos igualmente formadas/os pelos discursos das/os outras/os, a ideia de quem somos advém daquilo que ouvimos a respeito de nós mesmas/os. O olhar da/o outra/o é substancial para a construção da nossa própria identidade.

A sala de aula é um espaço construtor de identidades e que nos constitui como sujeitos (MOITA LOPES, 2012; MASTRELLA-DE-ANDRADE, 2010; GOMES, 1996). Uma vez que as identidades não são fixas ou eternas (BUTLER, 1999; SILVA, 2014), elas podem ser questionadas e problematizadas na escola, favorececendo a produção de novas identidades. Dessa maneira, estaremos buscando alternativas de conceber a realidade e construindo outros caminhos mais amplos que abarcam diferentes formas de vida.

Cabe, à/ao professor/a, ter sensibilidade para perceber as relações de poder que permeiam o ambiente de ensino e os discursos que posicionam constantemente os sujeitos em que nele se encontram. Para tanto, Ferreira e Brigolla (2013) sublinham a relevância de adotar abordagens inovadoras que levam em conta as diferentes realidades das/os alunas/os e que possam problematizar conceitos construídos na própria sala de aula.

Nas seções a seguir, abordo, em maiores detalhes, as concepções das identidades sociais de gênero e raça/etnia, que são o foco deste trabalho.

\subsubsection{Identidades sociais de gênero}

Nesta pesquisa, abordo e problematizo, em minhas aulas, as identidades de gênero, juntamente com as de raça/etnia. Infelizmente, o Brasil ainda é um país muito sexista que apresenta um grande número de mortes por questões de gênero. De acordo com o Instituto de Pesquisa Econômica Aplicada (IPEA), estima-se que entre 2009 e 2011, o Brasil registrou 16,9 mil feminicídios, ou seja, mortes de mulheres por conflito de gênero somente pelo fato de serem mulheres, sobretudo por casos de agressão cometidos por parceiros íntimos ${ }^{6}$.

\footnotetext{
${ }^{6}$ Disponível em: $<$ http://www.ipea.gov.br/portal/index.php?option=com_content\&id=19873 $>$. Acesso em: 21 dez. 2015, 10:32:20.
} 
Segundo dados da Organização Mundial de Saúde e do Instituto Brasileiro de Geografia e Estatística (IBGE), o Brasil é o sétimo no ranking mundial de assassinatos de mulheres ${ }^{7}$.

Conforme a Rede Brasil Atual, a Lei ${ }^{\circ} 11.340$, mais conhecida por Lei Maria da Penha, que protege as mulheres da violência doméstica e familiar, instituída em 2006 no Brasil, reduziu, desde a data de sua implementação até 2013, em 10\% a morte de mulheres por esse tipo de violência. ${ }^{8}$ Contudo, o impacto seria maior se não houvesse certos obstáculos a serem enfrentados pelas mulheres para denunciar. De acordo com a British Broadcasting Corporation Brasil, a quantidade de Delegacias da Mulher ainda é bastante restrita e não funciona $24 \mathrm{~h}$ por dia nem nos finais de semana, o que as leva a recorrerem às delegacias tradicionais onde não há o devido preparo dos agentes públicos para lidar com casos de violência desse tipo 9 . Ainda segundo o IPEA, para 26\% das/os brasileiras/os, mulheres que usam roupas que mostram o corpo merecem ser atacadas. ${ }^{10}$

Com base em dados como esses, é possível perceber que a supremacia masculina (FERREIRA; FERREIRA, 2011), que coloca o homem em um patamar de superioridade em relação à mulher, traz impactos diretos na vida das mulheres no Brasil. Acredito que a escola tem o papel de discutir temas da sociedade, pois uma das suas principais funções é formar cidadãs/os críticas/os. Assim, vale refletir sobre uma educação mais igualitária entre meninas e meninos e nas suas possíveis consequências para a sociedade.

Nessa perspectiva, as diferenças existentes entre os gêneros masculino e feminino e nas maneiras como eles operam nas relações sociais de poder se devem à cultura e não a aspectos biológicos. Aqui, vale ressaltar a diferença entre sexo e gênero. O sexo é biológico e é definido pelas características físicas e genéticas de uma pessoa, enquanto o gênero é uma construção social. Ele descreve aquilo que uma sociedade, em um dado momento histórico, define como feminino e masculino, daí o que Simone de Beauvoir quis dizer em sua obra $O$ Segundo Sexo, escrita em 1949. Segundo Louro (2008), a frase da autora "ninguém nasce mulher: torna-se mulher" (BEAUVOIR, 2009, p. 9) teve bastante impacto no mundo todo e foi repetida por militantes e estudantes para mostrar que seu modo de ser e estar no mundo se baseava em uma construção social, pois "fazer-se mulher dependia das marcas, dos gestos,

\footnotetext{
7 Disponível em: < http://www.compromissoeatitude.org.br/mapa-da-violencia-2012-atualizacao-homicidio-demulheres-no-brasil// > . Acesso em: 21 dez. 2015, 10:36:56.

${ }^{8}$ Disponível em: $<$ http://www.redebrasilatual.com.br/cidadania/2015/03/lei-maria-da-penha-reduz-em-10-mortede-mulheres-por-violencia-domestica-7576.html>. Acesso em: 21 dez. 2015, 10:47:32.

${ }^{9}$ Disponível em: $<$ http://www.bbc.com/portuguese/noticias/2015/12/151209_obstaculos_violencia_mulher_rm $>$. Acesso em: $21 \mathrm{dez}$. 2015, 18:23:34.

10 Disponível em: <http://ultimosegundo.ig.com.br/brasil/2014-04-04/resultado-de-pesquisa-sobre-ataquescontra-mulheres-estava-errada-diz-ipea.html> . Acesso em: 23 fev. 2016, 13:40:45.
} 
dos comportamentos, das preferências e dos desgostos que lhes eram ensinados e reiterados, cotidianamente, conforme normas e valores de uma dada cultura" (LOURO, 2008, p. 17).

Nesse sentido, Oliveira (2006) ressalta que homens e mulheres são categorias simbólicas, cujos papéis são construídos na sociedade. Para ela,

gênero não é sinônimo dos sexos masculino e feminino, mas uma categoria teórica correspondente ao conjunto de significados, símbolos e atributos que cada sociedade constrói, mediante sua história, para caracterizar e diferenciar cada um dos sexos. As diferenças biológicas entre homens e mulheres, assim como os papéis adequados a eles e a elas, são percebidos e interpretados segundo as construções de gênero de cada sociedade. (OLIVEIRA, 2006, p. 35).

Como destaca a autora, os papéis de gênero variam de acordo com a sociedade. São os valores atribuídos a homens e mulheres que vão interferir na maneira como são vistos e, consequentemente, na maneira como se constroem ao longo do tempo e do espaço.

Vivemos em uma sociedade onde o gênero masculino prevalece sobre o feminino, mas tal hierarquia é arbitrária e foi socialmente construída e reforçada ao longo dos anos, gerando diferenças que não são inatas e nem biológicas, mas sociais. Portanto, o gênero é uma ferramenta importante para compreender como se constroem as desigualdades entre homens e mulheres. Meninos e meninas, por exemplo, não recebem a mesma educação. Desde muito cedo, a sociedade define os papéis sociais de cada um, atribuindo qualidades e comportamentos diferentes. Os adjetivos utilizados para caracterizá-los é um exemplo dessa construção. As meninas são tidas como mais "sensíveis", "calmas", "ponderadas" "limpas” e “organizadas", já os meninos como mais "fortes", "durões", “impulsivos", “esportivos" e “objetivos”. Esses estereótipos vão influenciar na maneira como serão e nos espaços que vão ocupar nas suas vidas pessoais e profissionais (BRASIL, 2009).

Como pode ser visto, parte-se de aspectos biológicos para se chegar ao social, aos lugares que cada gênero poderia ou se esperaria alcançar. Nesse sentido, os PCNs de 1998 afirmam que

o conceito de gênero diz respeito ao conjunto das representações sociais e culturais construídas a partir da diferença biológica dos sexos. Enquanto o sexo diz respeito ao atributo anatômico, no conceito de gênero toma-se o desenvolvimento das noções de 'masculino' e 'feminino' como construção social. O uso desse conceito permite abandonar a explicação da natureza como a responsável pela grande diferença existente entre os comportamentos e os lugares ocupados por homens e mulheres na sociedade. Essa diferença historicamente tem privilegiado os homens, na medida em 
que a sociedade não tem oferecido as mesmas oportunidades de inserção social e exercício de cidadania a homens e mulheres. Mesmo com a grande transformação dos costumes e dos valores que vêm ocorrendo nas últimas décadas, ainda persistem muitas discriminações, por vezes encobertas, relacionadas ao gênero. (BRASIL, 1998, p. 321-322).

Como exemplo dessas diferenças, podemos citar as desigualdades existentes entre homens e mulheres no mercado de trabalho (BRASIL, 2009). A grande maioria dos postos de direção é chefiada por homens e ainda é possível ver significativas diferenças salariais entre homens e mulheres. Os homens também estão mais presentes nas áreas ditas exatas como engenharia, matemática, física e informática, enquanto as mulheres se concentram nas carreiras das ciências humanas, como enfermagem, nutrição, fonoaudiologia, serviço social, letras, entre outros. Ou seja, as mulheres se encontram substancialmente em profissões relacionadas ao cuidado e ensino, tidas como tipicamente femininas. Olhando de maneira superficial, parece que essas escolhas são naturais, baseadas em aptidões ou capacidades distintas entre homens e mulheres. Contudo, "se observarmos com atenção, veremos que a distribuição de homens e mulheres no mercado de trabalho e as desigualdades decorrentes podem ser socialmente compreendidas e atribuídas às assimetrias de gênero" (BRASIL, 2009, p. 40).

Dessa forma, é possível perceber que a sociedade constrói as identidades do que é ser homem e mulher e nós agimos de acordo com tal construção que nos é passada desde o berço, desde as cores do nosso quarto, das nossas roupas e dos nossos brinquedos. Há uma expectativa social do que homens e mulheres podem fazer, na maneira como devem falar, andar, brincar, se relacionar e uma expectativa sobre que lugares devem ocupar, tanto na vida profissional quanto pessoal. Contudo, "esses modelos de comportamento sexual e social podem se tornar verdadeiras prisões ou fontes de agudo sofrimento quando os rapazes e as moças não se encaixam nos estereótipos de gênero previamente designados" (BRASIL, 2009, p.53).

Tudo isso revela que as diferenças entre os gêneros não são naturais, mas socialmente construídas. Joan Scott (1995), uma grande especialista na história do movimento operário no século XIX e do feminismo na França, também traz uma reflexão social sobre o tema. Segundo a pesquisadora, o gênero indica uma construção social sobre os papéis que homens e mulheres exercem na sociedade, ele remete às suas identidades subjetivas. A autora ressalta que, de acordo com essa definição, o gênero é uma categoria social instituída sobre um corpo sexuado, revelando o quanto o termo é útil ao possibilitar uma forma de diferenciar a prática 
sexual dos papéis que são atribuídos a homens e mulheres. Assim, não se tem "a pretensão de negar que o gênero se constitui com ou sobre corpos sexuados, ou seja, não é negada a biologia, mas enfatizada, deliberadamente, a construção social e histórica produzida sobre as características biológicas" (LOURO, 2003, p. 22).

Em vista disso, no Brasil, Louro (2008) ressalta a afirmação de uma nova política cultural, a política de identidades, em que, sobretudo a partir dos anos 1960,

jovens, estudantes, negros, mulheres, as chamadas 'minorias' sexuais e étnicas passaram a falar mais alto, denunciando sua inconformidade e seu desencanto, questionando teorias e conceitos, derrubando fórmulas, criando novas linguagens e construindo novas práticas sociais. (LOURO, 2008, p. 20).

Para a autora, essa luta buscava tornar visíveis outros modos de viver, ressaltando suas estéticas, histórias, experiências e questões, em busca de uma autorrepresentação.

Outra pesquisadora de renome na área de relações de gênero é Auad que, em 2003, traz em seu texto uma reflexão a respeito das relações entre cidadania, educação em direitos humanos, categoria de gênero e democracia. Citando Benevides (1996), a autora diz que uma educação para a democracia tem como objetivo formar sujeitos para a vivência de valores republicanos e democráticos, tornando-se conscientes de seus semelhantes e fomentando a solidariedade. Trata-se de uma cidadania ativa que prepara para a participação na vida pública como governante ou como cidadã/o comum, pois, "a democracia não existe sem uma educação apropriada, sem a formação de cidadãos democráticos" (BENEVIDES, 1996 apud AUAD, 2003, p. 138).

Vale ressaltar que as categorias identitárias são somadas na forma como uma pessoa é vista na sociedade - o que chamamos de interseccionalidade das identidades. Nesse sentido, Oliveira (2006) destaca que o conceito de gênero, enquanto categoria científica, passou a ser associado aos conceitos de raça e classe social, nutrindo-se desses sistemas discriminatórios. Assim, ser mulher branca é muito diferente de ser mulher negra e, se somarmos a isso a classe social e a sexualidade, por exemplo, esse leque de diferenças se torna ainda maior.

As identidades sociais estão entrelaçadas e se relacionam na maneira como as pessoas se veem e são vistas pelas/os outras/os e como são representadas nos espaços sociais. 
Segundo hooks ${ }^{11}$ (2015), as categorias sociais se interseccionam produzindo diferentes tipos de opressões, exclusões e violências. Daí a importância de analisá-las em conjunto.

Tendo em vista a estreita relação do gênero com outras identidades sociais, decidi, juntamente com minha orientadora, interseccioná-lo com as de raça/etnia a fim de propor às/aos alunas/os reflexões mais amplas do papel dessas categorias identitárias na constituição da desigualdade social.

A seguir, passo a discutir sobre as identidades sociais de raça/etnia e a maneira como se deu sua construção ao longo dos anos em diferentes contextos.

\subsubsection{Identidades sociais de raça/etnia}

No Brasil ainda perdura a imagem de um país miscigenado onde não há diferenças raciais e todas/os têm as mesmas condições sociais. Esse é o chamado mito da democracia racial em nosso país. Apesar de ser o segundo maior país do mundo com a maior população negra, ficando atrás apenas da Nigéria (HERINGER, 2001), o Brasil ainda é um país muito racista: ao mesmo tempo em que vê a/o negra/o como inferior, se nega a assumir que existe preconceito. É o que Telles (2003) e Munanga (2013) ${ }^{12}$ chamam de "racismo à brasileira". Para Gomes (2005a), trata-se de um racismo ambíguo que se afirma através da sua própria negação.

No âmbito internacional, crises financeiras, guerras e catástrofes naturais têm levado milhões de pessoas a procurarem refúgio ou melhores oportunidades de vida em outros países. É o que vem acontecendo na Europa com as/os refugiadas/os provenientes da Síria e até mesmo no Brasil, quando haitianas/os vieram em busca de sobrevivência para refazerem suas vidas após o terremoto que destruiu Porto Príncipe em 2010. Esse movimento vem trazendo mudanças na escala local e global como o aumento do preconceito racial e étnico, por exemplo.

Tendo em vista que a nossa sociedade ainda é marcada por atos racistas e xenofóbicos, aumentando as tensões entre as pessoas e a exclusão de muitas delas, decidi trabalhar com as identidades raciais e étnicas nesta pesquisa.

\footnotetext{
11 O uso de letras minúsculas advém do próprio desejo da escritora de não querer chamar atenção para o seu nome, mas sim para os seus textos.

${ }^{12}$ Baseio-me aqui na videoaula referente à disciplina de Introdução à Teoria Social e Relações Raciais feita pelo autor e publicada em 14 de novembro de 2013. Disponível em: $<$ https://www.youtube.com/watch?v=7FxJOLf6HCA $>$. Acesso em: 23 abr. 2016, 20:34.12.
} 
No que tange às identidades sociais de raça e etnia, faço minhas as palavras de Ferreira (2012, p. 24), que entende "raça como social, histórica e culturalmente construída" e etnia como a referência a "grupos que dividem a mesma identidade cultural, como língua, religião e história, por exemplo". Ambos os conceitos, portanto, não apresentam qualquer conteúdo biológico ou essencial; negra/o, raça e etnia são termos social e historicamente construídos no imaginário das pessoas.

Segundo Telles (2003), o termo raça ainda carrega forte significação negativa na sociedade brasileira e é construído nas práticas discursivas cotidianas. Assim,

\begin{abstract}
a noção popular sobre raça é transmitida através de estereótipos, da mídia, de piadas, das redes sociais, do sistema educacional, das práticas de consumo, dos negócios e pelas políticas do Estado. Logo, a raça tem grandes implicações materiais para os brasileiros. (TELLES, 2003, p. 306).
\end{abstract}

O autor aponta que, no Brasil, a raça é baseada, sobretudo, na cor da pele e nos aspectos físicos e não na ascendência africana, sendo que tais aspectos são tidos como negativos. Assim, "a noção de cor dos brasileiros equivale ao conceito de raça, pois está associada à ideologia racial que hierarquiza pessoas de cores diferentes" (TELLES, 2003, p. 302). Em uma sociedade que privilegia a/o branca/o ao mesmo tempo em que marginaliza e discrimina a/o negra/o constantemente, ainda é possível observar o desejo de muitas/os negras/os em ser brancas/os, ou de se parecer como tal, ao mudar o aspecto e a cor dos cabelos ou a forma do nariz, por exemplo, em uma tentativa de se adaptar aos padrões estéticos brancos que circulam na sociedade. Essa fuga ao padrão "negro" sugeriria as 136 cores elencadas no censo do IBGE de 1976 com relação à cor da pele. ${ }^{13}$

No que diz respeito ao ato de se identificar racialmente, Ferreira (2006) sugere que

quando as pessoas são convidadas a se autoclassificar com relação à raça/etnia, suas decisões estão relacionadas às imagens que já foram construídas para elas e que são associadas ao que foi construído social e historicamente. E nos caso dos afrobrasileiros, eles escolhem passar pelo processo de embranquecimento, pois a cor preta está relacionada com imagens negativas que foram sendo construídas também social e historicamente. (FERREIRA, 2006, p. 46).

13 Disponível em: $\quad<$ https://www.google.com.br/webhp?sourceid=chrome-instant\&ion=1\&espv=2\&ie=UTF-

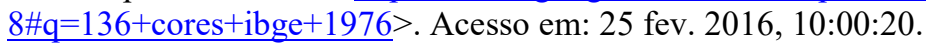


Esse fato aponta que "ser negra/o" ou se identificar como tal não depende exclusivamente da cor da pele. Nas palavras de Gomes (2005a, p. 43), "reconhecer-se numa identidade supõe, portanto, responder afirmativamente uma interpelação e estabelecer um sentido de pertencimento a um grupo social de referência". A autora afirma ainda que "a identidade negra se constrói gradativamente, num movimento que envolve inúmeras variáveis, causas e efeitos" (GOMES, 2005a, p. 43). A esse respeito, Azevedo (2010, p. 23) afirma que "ninguém nasce branco ou negro, mas é construído como tal no contexto de jogos de linguagem que associam percepção fenotípica e atributos identitários específicos”. Em outras palavras, ser negra/o não envolve apenas características fenotípicas. Trata-se de uma construção social feita por meio de discursos que inter-relacionam características físicas e sociais, dentro de uma escala de poder. Identificar-se como negra/o implica ainda sentimento de pertencimento a um determinado grupo social que compartilha ideias, valores e experiências de vida, tendo em vista que o processo identitário é uma construção histórica e social.

Corroborando essa mesma ideia, Cruz, Rodrigues e Barbosa (2011) argumentam que ser 'negra/o' ou 'preta/o' não está ligado apenas a características físicas; é 'negra/o' quem assim se define. Contudo, o termo tem sido utilizado para identificar pessoas com certos fenótipos de ascendência africana - pele escura, cabelo crespo etc. - e que vão ganhando significado social que pode ser revisado e reconstruído de forma positiva, valorizando o pertencimento à negritude. No que tange à raça, as autoras declaram que

\footnotetext{
a ideia inicial de raça foi construída a partir de associações às características biológicas e genéticas que outrora foram sustentação e justificativa para escravizar pessoas, por exemplo. No entanto, o termo 'raça' foi reformulado por movimentos sociais negros, em vários locais, associando-os às características positivas. Entretanto, ainda que tenha sido ressignificado, sabemos que esse termo é utilizado nas relações sociais brasileiras para informar de que maneira aspectos físicos (textura de cabelo, cor da pele, tipo de nariz) ainda são utilizados para classificar e hierarquizar pessoas, ou seja, podem determinar os lugares sociais que elas ocuparão. No campo teórico, 'raça' é utilizado como uma construção social. (CRUZ; RODRIGUES; BARBOSA, 2011, p. 35).
}

Segundo as autoras, o conceito de raça não tem qualquer fundamento biológico, mas sim uma função política e ideológica, uma vez que é pela raça que as/os negras/os são vistas/os no mundo social. A esse respeito, as Diretrizes Curriculares Nacionais para a 
Educação das Relações Étnico-Raciais e para o Ensino de História e Cultura Afro-Brasileira e Africana (BRASIL, 2004) ressaltam que

\begin{abstract}
é importante destacar que se entende por raça a construção social forjada nas tensas relações entre brancos e negros, muitas vezes simuladas como harmoniosas, nada tendo a ver com o conceito biológico de raça cunhado no século XVIII e hoje sobejamente superado. (BRASIL, 2004, p. 13).
\end{abstract}

Em vista disso, percebe-se o quanto o termo raça ainda é forte e significativo na nossa sociedade. Graças à luta do Movimento Negro, surgido na década de 1970, o termo vem sendo reconstruído e utilizado em sentido político e para valorização do legado deixado pelas/os africanas/os. Essa identidade positiva contribuiu para que mais pessoas se identificassem como negras/os ou afrodescendentes, algo que vem acontecendo nos últimos anos no Brasil. Segundo pesquisas do IBGE, houve um aumento na quantidade de pessoas que se declaram preta ou parda. ${ }^{14}$ Toda essa estrutura interfere na forma como nos vemos e vemos as/os outras/os. Nas palavras de Gomes (2005a),

\begin{abstract}
aprendemos a ver negros e brancos como diferentes na forma como somos educados e socializados a ponto de estas diferenças serem introjetadas em nossa forma de ser e ver o outro, na nossa subjetividade, nas relações sociais mais amplas. (GOMES, 2005a, p. 49).
\end{abstract}

Com base nessas definições, entendo raça como uma construção social cujo significado é produzido no discurso, nas relações sociais e em contextos sócio-históricos bem definidos, variando, portanto, de um lugar para outro. Como mencionado acima, no Brasil esse termo tem cor e, a partir dela, toda uma hierarquização social é feita.

Logo, ao se falar em questões étnico-raciais para a educação, vale ressaltar que o termo 'étnico' tem o intuito de reforçar essas relações conflituosas devido a diferenças na cor da pele e outros traços fisionômicos ligados à raiz cultural africana que trouxe outras visões de mundo, valores e princípios diferentes dos de origem indígena, europeia e asiática (BRASIL, 2004).

\footnotetext{
${ }^{14}$ Segundo dados do Censo de 2010 do IBGE, a porcentagem de pessoas que se declaravam pretas e pardas era, respectivamente, de $6,2 \%$ e $38,5 \%$ em 2000 e de $7,6 \%$ e $43,1 \%$ em 2010. Disponível em: $<$ http://biblioteca.ibge.gov.br/visualizacao/periodicos/93/cd_2010 caracteristicas populacao_domicilios.pdf $>$. Acesso em: 03 dez. 2015, 10:20:20.
} 
Segundo Cruz, Rodrigues e Barbosa (2011), após a abolição da escravatura a quantidade de negras/os era superior à de brancas/os. Com o intuito de conter esse crescimento, o Estado brasileiro incentivou e financiou a vinda de imigrantes brancas/os de origem europeia visando ao embranquecimento ${ }^{15}$ da população em alguns séculos. Houve ainda uma preocupação com a miscigenação e o futuro racial do Brasil, além de uma busca pela identidade nacional. Com a publicação de Casa Grande e Senzala em 1933, tal preocupação é atendida, pois, nessa obra, Gilberto Freyre (2005) subverte a imagem negativa da miscigenação racial que se torna central para a formação da desejada identidade nacional brasileira, sustentando que o Brasil estava livre do racismo que afligia tantos países.

Foi, então, construído o mito da democracia racial que, baseado na mestiçagem cultural e biológica das três raças originárias - a/o negra/o, a/o branca/o e a/o índia/o - agiria como diluidora dos conflitos, possibilitando a construção de uma identidade nacional do Brasil. Nesse sentido,

ao exaltar a ideia de convivência harmoniosa entre os indivíduos de todas as camadas sociais e grupos étnicos e assim permitir às elites dominantes dissimular as desigualdades, impede-se que os membros das comunidades não brancas tivessem consciência dos sutis mecanismos de exclusão da qual são vítimas na sociedade. (MUNANGA, 1999 apud CRUZ; RODRIGUES; BARBOSA, 2011, p. 19).

As autoras explicam ainda que o mito da democracia racial encobria os conflitos raciais, de maneira que todas/os pudessem se identificar como brasileiras/os. Tal concepção negava qualquer diferença racial ou étnica sugerindo um ideal implícito de homogeneização cultural. Ao não tratar das relações assimétricas de poder entre escravas/os e senhoras/es, construiu-se o nacionalismo necessário à modernização e à formação do Estado Nacional. Com isso, de 1933 até fins da década de 1970, o discurso da democracia racial enraizou-se no Brasil, levando à incapacidade de muitas/os brasileiras/os de identificar problemas raciais, chegando ao seu ápice no governo militar (CRUZ; RODRIGUES; BARBOSA, 2011).

Ainda segundo as mesmas autoras, essa democracia racial começa a ser criticada por volta da década de 1950, período em que estudiosas/os se juntaram para investigar as desigualdades raciais constatando que a desigualdade social no Brasil apresenta um elemento

\footnotetext{
${ }^{15}$ Segundo Cruz, Rodrigues e Barbosa (2011, p. 18), “embranquecimento é o nome dado às políticas adotadas pelo Estado brasileiro para conter o avanço da população negra e aumentar o número de brancos. Entre essas medidas está o financiamento da vinda de imigrantes europeus ao Brasil, incluindo a cessão de terras e valorização e incentivo de suas culturas para permanecerem no Brasil".
} 
racial. Nesse contexto, o Movimento Negro denunciou o racismo no Brasil, enfatizando suas lutas dentro do contexto educacional, sobretudo na denúncia contra a ideologia do branqueamento velado reproduzido nos livros didáticos e nas próprias escolas, bem como à omissão de conteúdos que enfatizassem a história das/os negras/os, o seu modo de ser e as suas habilidades. Além disso, o movimento enfatizou a limitação da/o negra/o ao acesso à educação e sua permanência na escola, tendo em vista que elas/es apresentam a maior porcentagem nos índices de analfabetismo, exclusão e repetência escolar. Um dos objetivos centrais do Movimento Negro, portanto, foi valorizar a história das/os afrodescendentes e o respeito à diversidade, vendo na educação uma possibilidade para a construção de uma identidade negra positiva, pois, nas palavras de Cruz, Rodrigues e Barbosa (2011, p. 29), “a educação é compreendida como a base sobre a qual se estrutura a forma de pensar e agir de um povo".

Contudo, podemos nos perguntar: após tantas lutas e reivindicações no cenário brasileiro, como o racismo ainda pode ser tão enraizado na nossa sociedade? A esse respeito, Oliveira (2006, p. 11) aponta que "o Brasil desenvolveu e adota o racismo mais eficaz do mundo: aquele cujo funcionamento não pode ser aferido, aquele que não tem um padrão, não é palpável nem evidente". Para a autora, apesar de ser praticado cotidianamente, ele não tem peso nem medida. O Brasil ainda apresenta uma sociedade racialmente hierarquizada que privilegia a/o branca/o em detrimento das/os demais. Mesmo sem estabelecer claramente o lugar de cada um/a na sociedade, a falta de oportunidades acaba por influenciar os espaços que a/o negra/o vai ocupar futuramente, gerando enormes desigualdades sociais e aumentando a violência. Mesmo que velado, o racismo está muito presente nas piadas, na mídia, no mercado de trabalho, nas escolas, nas universidades como também na segregação das cidades em centros e periferias.

A erradicação do racismo no Brasil é ainda mais difícil devido ao cenário social em que nos encontramos, pois, como nos traz Oliveira (2006), os efeitos do mito da democracia racial ainda estão muito presentes no imaginário coletivo das pessoas. Dentro dessa perspectiva, Gomes (2005b) reforça a importância de reconhecermos a maneira como o racismo se manifesta na sociedade brasileira a fim de combatê-lo. Também Munanga (2005, p. 18) aborda essa questão, afirmando que isso requer "uma transformação radical de nossa estrutura mental herdada do mito da democracia racial", para, a partir de então, podermos encontrar estratégias educativas e pedagógicas na intenção de combatê-lo. Ou seja, é preciso tomada de consciência sobre as diferentes formas de preconceito e discriminação racial no 
Brasil, além das suas consequências na vida das pessoas, para, posteriormente, podermos refletir sobre possíveis caminhos de erradicá-lo.

Munanga (2005) ressalta ainda outro ponto delicado da questão. Ao contrário do que muitas/os acreditam, o racismo não é característico da ignorância e da falta de estudos. Nas palavras do autor, "o preconceito é produto das culturas humanas que, em algumas sociedades, transformou-se em arma ideológica para legitimar e justificar a dominação de uns sobre os outros" (MUNANGA, 2005, p. 18).

Hooks (2010) segue na mesma direção quando ressalta o poder da supremacia branca na maneira como negras/os são vistas/os na sociedade. Segundo a autora, a supremacia branca reforça a noção de que as/os negras/os são academicamente inferiores. Isso se deve ao fato de a imagem da/o negra/o ter sido construída, ao longo dos anos, de maneira negativa. Na visão da autora, os preconceitos são inconscientes e estão baseados nessa supremacia. Daí o porquê das mudanças não ocorrerem rapidamente. Isso torna o combate ao racismo ainda mais desafiador, uma vez que não bastam estudos e leituras na área para solucionar o problema do preconceito. É preciso ir além da teoria e agir por meio da práxis a fim de reconstruir novos valores. Freire (2011, p. 52) define práxis como "reflexão e ação dos homens sobre o mundo para transformá-lo". Isso requer mudanças nas nossas práticas sociais e possibilitar acessos às/aos negras/os para que possam ocupar espaços antes reservados às/aos brancas/os.

Trazendo para o contexto europeu, Santerini (2015) ressalta a ascendência do racismo, da xenofobia e da intolerância, sobretudo, contra as/os imigrantes, as/os muçulmanas/os e as/os judias/judeus. Segundo a autora, isso se deve à crise econômica e à instabilidade geopolítica de alguns países da África do Norte e do Oriente Médio. De acordo com Santerini (2015, p. 1), com algumas diferenças do racismo tradicional, que, baseado em características biológicas afirma a existência de hierarquia entre as raças, a Europa presencia atualmente um "novo racismo"16 fundado nas diferenças culturais. Segundo a autora, essa forma de racismo coloca as civilizações em concorrência, aumentando a intolerância e o isolamento cultural.

Neste trabalho, intersecciono as identidades de gênero e raça/etnia a fim de obter uma análise mais ampla de como as categorias sociais interagem entre si trazendo especificidades nas vidas das pessoas. Tendo em vista que somos seres de múltiplas identidades, nossa maneira de agir no mundo se relaciona com o modo pelo qual nos vemos inseridos nele. Dessa forma, ao se falar da opressão de gênero, por exemplo, é importante trazer o recorte racial, buscando analisar como tais identidades sociais se combinam, produzindo diferentes

\footnotetext{
${ }^{16}$ Tradução de: Néo-racisme.
} 
discriminações. A esse respeito, Carneiro (2004) destaca que as mulheres negras sofrem dupla opressão: sexista e racista. Daí a importância de analisá-las concomitantemente.

Com base nesse ângulo, se os conceitos de gênero e raça/etnia são culturais e socialmente construídos nos diferentes espaços sociais, parte-se do pressuposto de que tais construções, quando reforçadas cotidianamente, podem ser discutidas, problematizadas, questionadas e, portanto, reconstruídas em busca de uma equidade entre homens e mulheres, brancas/os e negras/os e entre diferentes grupos étnicos no que tange ao acesso a direitos sociais, políticos e civis.

Dessa forma, sem uma devida conscientização do nosso trabalho, corremos o risco de propagar e reforçar estereótipos e preconceitos caso não assumamos uma postura crítica em sala de aula que possibilite reflexão sobre nossas práticas sociais, como também sobre práticas culturais dos países falantes da língua-alvo. É o que prescrevem as perspectivas críticas e transgressivas de ensino de línguas que visam à formação cidadã das/os nossas/os alunas/os em prol de uma sociedade mais justa e menos preconceituosa.

A fim de melhor compreendermos a maneira de trabalhar em sala de aula com vistas à transformação social, passo a falar, na seção seguinte, das concepções de ensino dentro do letramento crítico.

\subsection{O Letramento crítico}

As teorias de letramento são relativamente recentes no Brasil. Segundo Soares (2004, p. 6), o termo "letramento" surgiu na década de 80 no Brasil concomitantemente com acepções semelhantes na França, em Portugal, nos Estados Unidos e na Inglaterra a fim de nomear fenômenos distintos dos conhecidos como alfabetização. Na visão da pesquisadora, o letramento se refere a práticas sociais de leitura e escrita ao passo que a alfabetização está ligada à aprendizagem do sistema de escrita. A esse respeito, Monte Mór (2015, p. 32) destaca que o alfabetizado é "aquele que sabe ler e escrever de acordo com um conceito restrito de alfabetização, ou seja, um conceito que desconsidera/não prioriza a prática social da linguagem".

O letramento, por sua vez, é uma prática social que demanda experiência de mundo para poder agir nas diferentes esferas da sociedade. Na concepção de Soares (1998, p. 72), "letramento não é pura e simplesmente um conjunto de habilidades individuais, é o conjunto de práticas sociais ligadas à leitura e à escrita em que os indivíduos se envolvem em seu 
contexto social". Em outras palavras, o letramento é o resultado do ensino e aprendizagem da leitura e escrita. Ele implica a ação nas diferentes práticas sociais do nosso quotidiano.

Tendo em vista que este trabalho se insere no domínio da LA, mais precisamente dentro da perspectiva crítica de ensino, que busca refletir questões sociais e políticas em sala de aula, julgo pertinente esclarecer como entendo a língua e a sua função na sociedade. Assim, nesta seção, abordo primeiramente o conceito de língua como prática social imbricada de ideologias e relações de poder (FAIRCLOUGH, 2008; THOMPSON, 1990). Na seção seguinte, apresento os aportes de Paulo Freire (2011) para uma educação problematizadora que questiona aspectos da realidade por meio da reflexão crítica, visando transformá-la. Em seguida, apresento algumas concepções do letramento crítico na sala de aula de línguas tendo em vista autores como Menezes de Souza (2011a, 2011b), Jordão (2015), Monte Mór (2015), Mattos (2015), Duboc (2015), dentre outros. Na última seção, abordo os documentos oficiais da educação que preveem um ensino voltado para a reflexão crítica da sociedade (BRASIL, 1998; BRASIL, 2006; BRASIL, 2016).

\subsubsection{Língua como prática social e ideológica}

Neste trabalho, recorro à definição de língua trazida por Fairclough (2008). O autor apresenta a concepção de língua como discurso, como prática social, ou seja, uma maneira de agir nas diversas situações da realidade. Para o autor, o discurso é "[...] o uso da linguagem como forma de prática social [...], um modo de ação, uma forma em que as pessoas podem agir sobre o mundo e especialmente sobre os outros, como também um modo de representação" (FAIRCLOUGH, 2008, p. 90-91). Dessa maneira, o discurso não é uma atividade individual, mas é construído socialmente. Ele é uma prática de representação da sociedade como também de significação do mundo. Em outras palavras, o discurso não apenas representa uma determinada sociedade, histórica e culturalmente, mas também interpreta e dá sentido a ela.

O autor afirma ainda que o discurso é socialmente constitutivo, sendo moldado pela estrutura social. Nesse sentido, o autor apresenta três aspectos dos efeitos construtivos do discurso: ele constrói as identidades sociais, as relações sociais e os sistemas de conhecimento e crença. A primeira, chamada de função identitária, se volta para a maneira como as identidades sociais são estabelecidas no discurso. A segunda, a função relacional, a como as relações sociais entre as/os participantes são representadas e negociadas. A terceira, a função ideacional, a como os textos dão sentido ao mundo (FAIRCLOUGH, 2008). 
O discurso se torna relevante aqui uma vez que ele constrói as identidades sociais, ou seja, as posições dos sujeitos no mundo, como também a compreensão que temos de nós mesmos, e isso interfere diretamente nas relações pessoais estabelecidas por esses sujeitos. Além disso, ele constrói nossos valores e nossas crenças, que interferem na nossa maneira de dar sentido ao mundo. Dessa forma, o discurso contribui não apenas para reproduzir a sociedade, mas também para transformá-la. Ademais, o autor afirma que a prática social apresenta diferentes orientações, sejam elas econômicas, políticas, culturais ou ideológicas, podendo, o discurso, estar imbricado de todas delas. Assim, "o discurso como prática ideológica constitui, naturaliza, mantém e transforma os significados do mundo de posições diversas nas relações de poder" (FAIRCLOUGH, 2008, p. 94).

Nesta pesquisa, entendo ideologia não de forma neutra, mas como uma maneira de usar o discurso para estabelecer ou manter formas de opressão. Para tanto, recorro à concepção de Thompson (1990) que, em seu texto, apresenta uma concepção crítica de ideologia. $\mathrm{O}$ autor busca compreender como as formas simbólicas interagem com as relações de poder, ou seja, como os valores e as crenças constroem relações de poder. Nas palavras do autor, "estudar a ideologia é estudar as maneiras como o sentido serve para estabelecer e sustentar relações de dominação" (THOMPSON, 1990, p. 76).

Assim como traz o autor, entendo a ideologia como as diversas estratégias utilizadas para construir ou reforçar relações de dominação e de desigualdades, sejam elas baseadas na classe, no sexo, na raça/etnia, na sexualidade etc. Assim, acredito que os discursos que visam ratificar e manter as hierarquias e estruturas sociais, sem buscar transgredi-las e transformálas, são ideológicos.

Na seção seguinte, apresento a influência de Paulo Freire e os aportes da sua educação libertadora para o letramento crítico.

\subsubsection{Os aportes de Paulo Freire para o letramento crítico}

Paulo Freire foi um grande educador, pedagogo e filósofo brasileiro que se tornou mundialmente conhecido por desenvolver uma pedagogia crítica de ensino. Tal pedagogia busca uma educação libertadora por meio da consciência crítica do lugar do ser humano no mundo. Em 1970, o autor apresenta a educação como prática da liberdade em sua obra Pedagogia do Oprimido. Nessa obra, o educador critica a educação bancária, que apenas transfere conhecimentos, tornando a educação um "ato de depositar, de transferir, de transmitir valores e conhecimentos" (FREIRE, 2011, p. 82). Para o autor, nessa visão 
distorcida da realidade não há criatividade, transformação nem mesmo saber, já que este exige invenção, reinvenção, uma busca constante e impaciente do homem no mundo, com o mundo e com as/os outras/os. Na educação bancária, a/o educador/a é tida/o como aquela/e que sabe e pensa, que tem autoridade sobre o saber. As/Os educandas/os são vistas/os como as/os que não pensam e nada sabem, são meros objetos que recebem passivamente o conhecimento transmitido. Nas palavras do autor, “o educador vai 'enchendo' os educandos de falso saber, que são os conteúdos impostos" (FREIRE, 2011, p. 100).

Paulo Freire propõe, então, uma educação libertadora onde o conhecimento é construído por meio do diálogo com vistas à transformação social. Para ele, a educação problematizadora é um ato cognoscível que supera a contradição educador/a-educandas/os; estas/es são, simultaneamente, educadoras/es e educandas/os, sujeitos do processo. Na prática libertadora, "vão os educandos desenvolvendo o seu poder de captação e compreensão do mundo que lhes aparece, em suas relações com ele, não mais como realidade estática, mas como uma realidade em transformação, em processo" (FREIRE, 2011, p. 100). Assim, as/os educandas/os deixam de ser objetos passivos para se tornarem sujeitos ativos e responsáveis pelo seu aprendizado. A própria realidade se apresenta como conteúdo e tema a ser discutido e refletido em sala de aula.

Em sua obra, o autor ressalta que a consciência crítica leva à liberdade. Tal consciência se dá quando o sujeito sai da ingenuidade. A conscientização implica inserção crítica na realidade a fim de melhor conhecê-la para transformá-la. Ela é feita pela práxis, ou seja, pela reflexão e ação, pois, como ressalta o autor, é necessária a reflexão para agir no mundo. Suas preocupações com a promoção de uma educação voltada para a cidadania crítica são reconhecidas internacionalmente e suas propostas de educação se voltam para a (re)construção de significados socialmente contextualizados e, inevitavelmente, imbricados de ideologias. Na visão de Paulo Freire, a educação ganha destaque na vida social da/o aluna/o. Nela, é possível refletir sobre os valores e crenças que permeiam a vida das/os educandas/os para que possam, a partir da conscientização, atuar nas diversas práticas sociais, transformando a realidade. Esses ideais coadunam-se com as perspectivas de educação encontradas no letramento crítico que prevê uma preparação da/o educanda/o para "usar a língua(gem) de maneira crítica e responsável, consciente do seu papel no mundo globalizado e preparado para agir nele" (TILIO, 2015a, p. 51).

A seguir, passo a falar, em maiores detalhes, da concepção do letramento crítico para o ensino de línguas. 


\subsubsection{O letramento crítico no ensino de línguas}

O letramento crítico (LC) se baseia nos aportes da pedagogia crítica freireana como também da LA transgressiva que, segundo Pennycook (2006), busca estabelecer relações entre o ensino de línguas e o mundo social. Esse ensino abarca a concepção da pedagogia como prática da liberdade e como transgressão, ou seja, "um movimento contra as fronteiras e para além delas" (HOOKS, 2013, p. 24). Pennycook (2001, 2006, 2010) defende um ensino de línguas problematizador voltado para questões mais amplas e políticas da sociedade com vistas ao engajamento das/os alunas/os na transformação social.

$\mathrm{Na}$ visão dessas/es autoras/es, esse ensino prevê discutir e refletir sobre questões que vão além do conteúdo encontrado nos materiais de apoio, como os livros didáticos, por exemplo. Nesse sentido, Uzêrda Freitas e Pessoa (2012, p 151) destacam que "a reflexão crítica se consolida na problematização dos construtos hegemônicos que perpassam o ambiente escolar". Em outras palavras, ele busca questionar as práticas sociais e os discursos cristalizados que constroem identidades sociais, problematizando temas críticos (URZÊDA FREITAS, 2013), que envolvem questões de poder, resistência e desigualdade.

Esse pensamento é também encontrado nas obras de bell hooks, pesquisadora americana de grande destaque na perspectiva transgressiva de ensino e reconhecida por seus trabalhos na área do feminismo e do racismo. Baseada em Paulo Freire, hooks (2013) defende a educação como prática da liberdade por meio de um ensino transgressor que ultrapassa as fronteiras da raça, do gênero e da classe social. Suas obras se voltam, sobretudo, para a reflexão desses construtos sociais nas aulas de línguas por meio de uma educação para a consciência crítica a fim de romper estereótipos e mudar o status quo.

Como já foi dito, o LC se insere nas perspectivas críticas e transgressivas de ensino, pois se baseia na reflexão e problematização das práticas sociais com vistas à uma formação cidadã. No Brasil, são crescentes os estudos de LC, sobre suas concepções e vantagens para a educação, sobretudo no contexto de ensino e aprendizagem de línguas. Para Menezes de Souza (2011a), o LC permite alcançar o objetivo pedagógico atual de preparar aprendizes para lidar com todo tipo de diferença.

$\mathrm{Na}$ visão do autor, são grandes as condições sociais e históricas que interferem no processo de significação, responsáveis pelas diferenças. Dentro da impossibilidade de eliminá-las, o autor chama a atenção para a importância de aprender a escutar não apenas a/o outra/o, mas nós mesmos ouvindo a/o outra/o. Nas suas palavras, 
letramento crítico consiste em não apenas ler, mas ler se lendo, ou seja, ficar consciente o tempo inteiro de como eu estou lendo, como eu estou construindo o significado... e não achar que leitura é um processo transparente, o que eu leio é aquilo que está escrito... Pensar sempre: por que entendi assim? Por que acho isso? De onde vieram as minhas ideias, as minhas interpretações? (MENEZES DE SOUZA, 2011b, p. 296).

A esse respeito, Jordão (2015) explica que o LC pressupõe que somos capazes de construir sentidos, de agir no mundo e de transformar a realidade. O sujeito é capaz de narrar a si mesmo e às/aos outras/os criticamente e se vê tanto como narrador, tanto quanto narrado, se posicionando como agente no processo de construção de si e das/os outras/os. Dessa forma, busca-se compreender por que eu leio da forma que leio, pois os sentidos que eu construo podem ser diferentes dos sentidos que outros sujeitos constroem, justamente por serem influenciados por seus contextos sociais (MENEZES DE SOUZA, 2011a). Isso implica questionar-se por que eu entendo da forma que entendo, e o que determinado evento tem a ver com a minha vida, o que ele significa para mim, ou ainda, o que ele significa para a/o outra/o.

Enfatizando a importância da educação na preparação das/os alunas/os diante das diferenças, Gomes (2006) ressalta que a escola é o espaço da diversidade, é onde diferentes costumes, comportamentos, raças/etnias se encontram, ou seja, as desigualdades sociais e raciais do nosso país estão presentes no ambiente escolar. Para a autora, como educadoras/es, que vivemos em um contexto de desigualdades, exclusão e discriminação, devemos possibilitar que o tempo na escola seja devidamente cumprido "como um direito social que garanta, dê espaço, discuta e explore, de forma democrática, a vivência da diversidade e possibilite aos alunos a sua formação enquanto cidadão e sujeitos emancipados" (GOMES, 2006, p. 26). Ainda segundo a autora, não é possível ser educador/a sem assumir uma postura política, ética e pedagógica.

Monte Mór também vem se destacando na divulgação e explanação das características fundamentais desse ensino no contexto da educação brasileira. Para a autora, os novos estudos de letramentos enfatizam a necessidade de ampliação do enfoque crítico para o desenvolvimento de habilidades que possibilitem vivência em uma sociedade globalizada e digital (MONTE MÓR, 2015). Nas palavras da autora,

a crítica constitui-se um elemento imprescindível para um projeto que prevê investigar o fenômeno da globalização e a presença da tecnologia na sociedade, assim como revisar, ampliar e ajustar currículos, epistemologias, habilidades, capacidades, conceitos de linguagem, de cidadania, a relação escola-sociedade, as 
relações entre professor-aluno (e as identidades destes), a linguagem em suas modalidades e práticas. (MONTE MÓR, 2015, p. 47-48).

Como visto no primeiro capítulo, a globalização traz inúmeras consequências na vida das pessoas, sobretudo na maneira de agir sobre o mundo. Nossos olhares sobre a realidade, nossos pontos de vista e, consequentemente, nossas práticas sociais mudaram. Dessa forma, os objetivos educacionais também sofrem alterações, pois os sujeitos estão em constante transformação e apresentam múltiplas identidades. Assim, é relevante repensar os currículos e o papel da escola no intuito de se adaptar às novas demandas da sociedade contemporânea.

Para Monte Mór (2015, p. 47), as constantes renovações na prática da crítica nas diferentes instâncias da educação fez emergir os recentes estudos de letramentos, sobretudo do LC, que "operam segundo revisões paradigmáticas de educação, sociedade, trabalho e participação social". Assim,

\begin{abstract}
a habilidade crítica se revela um elemento fundamental nas propostas educacionais que levam em conta as teorias e práticas de letramento. O desenvolvimento dessa habilidade se dá num processo expansivo e de mão-dupla, voltado para a sociedade de agora. Traduz-se no desenvolvimento de habilidades de percepção social, de construção de sentidos, do reconhecimento de outras formas e construção de conhecimento (diferentes das tradicionais e legitimadas), de promoção de agência e de cidadania ativa, dentre outras habilidades que despontam e se fazem conhecidas. (MONTE MÓR, 2015, p. 45).
\end{abstract}

Essa proposta de educação traz, portanto, para a sala de aula, questões da sociedade com o intuito de serem refletidas, repensadas e problematizadas a fim que, posteriormente, a ela retorne. A sociedade se torna, assim, a origem e o "desembocar" da educação que tem o papel de discutir questões sensíveis e que fazem parte da realidade da/o aluna/o. Seu objetivo é promover a agência das/os educandas/os para que, ao se encontrar novamente na sociedade, possam agir como cidadãs/os nas diferentes práticas sociais. Nesse sentido, Ferreira (2015) sublinha que o LC é tido como uma ferramenta para compreender o contexto social, político e ideológico em que a/o aluna/o se encontra.

Neste trabalho, entendo agência como "uma forma de intervir no processo discursivo de construção de sentidos e representações do mundo" (JORDÃO, 2010, p. 432). Os sentidos aqui não são entendidos como estáveis, logo, eles podem ser confrontados e desafiados. Tendo em vista que o sujeito pós-moderno é fragmentado e constituído por múltiplas 
identidades, ele constrói sentidos a partir da maneira como ele vê e compreende o mundo. Dessa maneira, o sujeito pode intervir e se posicionar diante dos discursos, resistindo a eles.

No que tange à habilidade de construção de sentido, Monte Mór (2015) advoga que ela se desenvolve juntamente com a habilidade crítica, desenvolvendo a autoria da/o aluna/o e a sua agência. Tais eventos corroboram o pensamento freireano, pois, ao abrir possibilidades de reconstruir sentidos cristalizados e construir novos, ampliam-se as leituras de mundo para que novas transformações sejam feitas. Monte Mór (2015) ressalta ainda que uma pessoa pode ser crítica independentemente do seu grau de escolaridade. Trata-se de uma proposta de ensino que promove o pensamento reflexivo das/os alunas/os e está relacionado à capacidade de percepção crítica que as/os cidadãs/os têm da sua realidade social.

Neste trabalho, entendo uma pessoa crítica como aquela que tem consciência das suas múltiplas identidades, da sua realidade social e dos contextos nos quais se vê inserida, sendo capaz de associar aquilo que vê, lê e ouve ao seu mundo, construindo significados contextualizados e percebendo de que maneira determinada informação interfere na sua vida pessoal e profissional. Ela é consciente da influência da história e da cultura na construção das identidades sociais e suas consequências na vida das pessoas. Além disso, ela é capaz de identificar discursos ideológicos que visam criar ou sustentar relações de dominação.

Nesse sentido, o LC visa, além da percepção crítica sobre a realidade, a uma educação para a cidadania, vista como "um valor social a ser desenvolvido em várias disciplinas escolares" (BRASIL, 2006, p. 91). Seguindo o mesmo raciocínio, Mattos (2015, p. 177) enfatiza que "o conceito de cidadania envolve a tomada de decisões, ou práticas sociais, por parte de sujeitos ativos e localizados sócio-historicamente e, ao mesmo tempo, imersos numa sociedade altamente globalizada". Citando Pashby (2008), a autora reflete que

\footnotetext{
a educação para a cidadania visa à formação de cidadãos ativos, que possam ser agentes de mudança, preparando crianças e jovens para um futuro cada vez mais globalizado, onde as fronteiras sociais e geográficas são muitas vezes turvas. Educar para a cidadania significa, então, compreender e reconhecer diversas culturas, aprender para a vida, o que garantiria que, quando adultos, os alunos estarão preparados para a mobilidade social e equipados com as habilidades sociais que são essenciais para seu crescimento, mas também equipados com uma consciência crítica e com senso global de responsabilidade. (PASHBY, 2008 apud MATTOS, 2015, p. 179).
}

Como podemos perceber, a educação para a cidadania pressupõe todo um emaranhado de conhecimentos que auxiliam a/o aprendiz a ser agente no processo de transformação da sua 
realidade, alguém com conhecimentos culturais e de vida que poderá interagir com pessoas que compartilham de diferentes culturas e opiniões. Dessa forma, entendo o LC como uma prática pedagógica que busca favorecer o questionamento das práticas sociais. Esse ensino busca problematizar, no ambiente escolar, questões sociais que permeiam a vida das/os educandas/os, como as de gênero e raça/etnia, desenvolvidas nesta pesquisa.

O LC questiona crenças e valores tidos como verdades absolutas, revelando o seu caráter subjetivo por meio da reflexão. A partir do questionamento da sua realidade, o sujeito pode desenvolver progressivamente o seu olhar crítico e atento para as situações e eventos que ocorrem ao seu redor. Uma vez conscientes do caráter subjetivo das crenças, as/os alunas/os podem repensar as práticas culturais de uma determinada sociedade para, então, engajar-se no que Freire (2011) chama de práxis libertadora, transformando as práticas sociais que, muitas vezes, aprisionam sujeitos e limitam suas ações no mundo.

O LC vê na educação uma forma de resistência e um espaço para problematização, desconstrução e desestabilização das sociabilidades (HOELZLE, 2016) com vistas a pensar criticamente o mundo e a construir conhecimentos para uma vida democrática em sociedade. A escola ganha papel de destaque na formação de cidadãs/os críticas/os, pois, nela, é possível repensar o poder da linguagem na construção de identidades, capacitando-as/os a agir no mundo em prol de uma sociedade mais justa e igualitária.

Vale ressaltar que o LC não é um método de ensino, mas uma disposição para a ação e uma maneira de agir em sala de aula, que considera a língua não como descrição de realidades, mas como constitutiva delas; portanto, os textos da vida social são espaço de ação. Nesse sentido, Duboc (2015) propõe o trabalho do LC nas brechas da sala de aula, nas brechas dos materiais e dos currículos tradicionais de ensino para agirmos em prol da aprendizagem, da reflexão e da problematização, expandindo a perspectiva do currículo tradicional, já que uma proposta pós-moderna de educação defende que o que se aprende na escola não deve ser apenas algo a ser constatado pelas/os alunas/os, mas problematizado.

Seguindo o mesmo raciocínio, Ferreira (2006, p. 35), assevera que essa prática "relaciona-se com a forma como se ensina em sala de aula, seus objetivos, seu papel na sociedade e a habilidade de agir reflexivamente". Ou seja, não se trata de uma metodologia a ser seguida, mas de uma forma de agir, uma postura a ser tomada, sempre tendo em mente o papel da escola e da/o professor/a de educar e problematizar questões sociais consideradas até mesmo tabus, como é o caso da violência contra a mulher e do racismo, crimes que, infelizmente, ainda estão muito presentes na sociedade brasileira. 
Na seção a seguir, apresento os documentos oficiais da educação que auxiliam as/os professoras/es na construção de práticas pedagógicas voltadas para uma formação cidadã.

\subsubsection{Documentos educacionais oficiais}

A escola é um espaço de suma relevância para a construção da vida social. É o primeiro lugar, longe dos contextos familiares, onde o sujeito entra em contato com outras possibilidades de construção social sobre quem é ou pode ser (MOITA LOPES, 2012, p. 9). Segundo o autor, as aulas de língua ainda estão distantes da vida social e do envolvimento das/os alunas/os no discurso. A fim de possibilitar o ensino dentro da perspectiva do LC, o autor reforça o trabalho com temas transversais, ou seja, questões que permeiam o universo das/os alunas/os, como previsto pelos documentos educacionais, já que usamos a língua para construir significados acerca dos diversos temas e assuntos da sociedade, construindo a nós mesmos e o mundo social que nos cerca. Nesse sentido, Tilio (2015a) considera que o ensino de línguas é um espaço privilegiado para discussão de temas sensíveis, pois o seu aprendizado possibilita usar a língua partindo do seu próprio uso, permitindo refletir sobre como ela funciona nas práticas sociais.

Os PCNs, já em 1998, abordam a importância de discutir em sala de aula questões sociais como meio de perceber de que maneira as pessoas agem na sociedade através dos discursos. Eles trouxeram a relevância de problematizar, por exemplo, o papel da mulher na sociedade e a organização política das minorias étnicas. De acordo com o documento, "os temas transversais podem ser focalizados pela análise comparativa de como questões particulares são tratadas no Brasil e nos países onde as línguas estrangeiras são faladas como língua materna e/ou língua oficial” (BRASIL, 1998, p. 44).

Anos mais tarde, em 2006, as OCEMs ratificam esse ensino e enfatizam a prática de leitura segundo as teorias de LC e dos multiletramentos a fim de contribuir para uma formação cidadã. Nesse sentido,

[...] o conceito de letramento se afasta da concepção de linguagem, cultura e conhecimento como totalidades abstratas e se baseia numa visão heterogênea, plural e complexa da linguagem, de cultura e de conhecimento, visão essa sempre inserida em contextos socioculturais. Entendemos que a linguagem, quando considerada de maneira abstrata, distante e desvinculada de seus contextos socioculturais e de suas comunidades de prática, pode resultar em prejuízos graves nos âmbitos humano e pedagógico. Essa é a razão que nos leva à concepção de letramento como prática sociocultural. (BRASIL, 2006, p. 109). 
As práticas de letramento estão igualmente previstas na BNCC em sua versão de 2016. O documento enfatiza a importância de problematizar identidades sociais na aula de línguas a fim de capacitar a/o educanda/o para lidar com as inúmeras informações presentes no seu cotidiano, refletindo sobre elas e usando-as para resolver problemas da sociedade. Assim,

\footnotetext{
o fortalecimento de identidades, de vínculos e de protagonismo responsável requer desnaturalizar o conhecido e desenvolver a capacidade de acessar, selecionar e usar, de modo criativo e confiante, fontes de informação e conhecimentos para lidar com os desafios humanos e sociais do mundo em que vivem. (BRASIL, 2016, p. 368).
}

Contudo não basta propor um trabalho com identidades sem favorecer uma reflexão crítica das/os alunas/os, instigando-as/os a compreender historicamente porque as coisas vieram a se dar da forma que estão (PENNYCOOK, 2001). Trabalhar dentro dessa perspectiva implica compreender que os significados não estão encerrados nos textos, mas são produzidos pelas/os leitoras/es dentro de contextos sociais e históricos específicos e imersos em relações de poder, "daí ser a leitura uma atividade de linguagem que envolve conhecer o mundo, ter uma visão desse e refletir sobre as possibilidades e as conveniências de transformação social" (BRASIL, 2006, p. 116). Dentro dessa perspectiva, "ganham ênfase as representações e as análises a respeito de diferenças, tais como: raciais, sexuais, de gênero e as indagações sobre quem ganha ou perde em determinadas relações sociais" (BRASIL, 2006, p. 116). Assim, não basta reconhecer a diversidade ou as diferenças, é preciso discutir as relações de poder entre elas.

No que tange à questão de gênero, Giesel (2012) enfatiza a necessidade de problematizar o tema devido aos ranços patriarcais e sexistas que ainda marcam os discursos das/os brasileiras/os. Para discutir o papel da mulher na sociedade, a autora defende, com base nas teorias feministas e na pedagogia freireana, o uso de uma abordagem sociointeracionista humanizadora que "permite que as interações em sala de aula não sejam somente visualizadas como precursoras de transformação, mas que elas tragam consigo a possibilidade de resgatar o teor da essência humana, fazendo, assim que os seres humanos busquem a plenitude de sua existência" (GIESEL, 2012, p. 112). Ou seja, não basta transformar, é preciso ainda humanizar para buscar a plenitude humana.

Outro grande aporte para o ambiente escolar e a sociedade, em particular, foi a aprovação da Lei Federal n. ${ }^{\circ} 10.639$ de 09 de janeiro de 2003 (BRASIL, 2003), que altera a 
Lei n. ${ }^{\circ}$ 9.394, de 20 de dezembro de 1996 (BRASIL, 2014) que estabelece as Diretrizes e Bases da Educação Nacional (LDB). A alteração incluiu no currículo oficial da Rede de Ensino a obrigatoriedade da temática História e Cultura Afro-Brasileira. Em 2004, o Conselho Nacional de Educação aprovou o Parecer CNE/CP n. ${ }^{\circ}$ 003/2004 (BRASIL, 2004), que regulamenta as alterações da LDB, instituindo as Diretrizes Curriculares para a Educação das Relações Étnico-Raciais e para o Ensino de História e Cultura Afro-Brasileira e Africana. Com isso, torna-se obrigatório o ensino dessa temática no âmbito de todo o currículo escolar, sobretudo nas disciplinas de Educação Artística, Literatura e História (BRASIL, 2003; BRASIL, 2004).

A aprovação de tais leis leva em consideração os estudos sobre raça e etnia, um dos temas focados nesta pesquisa. Os estudos raciais na educação são de extrema relevância, pois, assim como nos traz Gomes (2006, p. 36), "refletir sobre a cultura negra é considerar as lógicas simbólicas historicamente construídas, ao longo da história, por um grupo sociocultural específico: os descendentes de africanos escravizados no Brasil”. Isso implica conhecer o outro lado da história, o ponto de vista daquelas/es que foram, por muito tempo, silenciadas/os e que tanto contribuíram para formação da nossa cultura e identidade nacionais.

Em vista disso, é primordial refletir sobre a situação das/os negras/os que durante séculos foram escravizadas/os no Brasil sem nenhum questionamento moral. Mesmo após a abolição da escravatura, o país não propôs políticas de inserção desse grupo étnico que continuou à margem da sociedade, alvo de preconceitos e humilhações que perduram até os dias de hoje, mesmo que de forma velada, nas entrelinhas. Porém, nada disso elimina a dor de ser constantemente rejeitada/o e excluída/o não só dos espaços privilegiados da sociedade, mas dos padrões de beleza veiculados pela mídia e pelos livros didáticos.

Para melhor compreensão do que seja a educação das relações étnico-raciais, o Parecer do Conselho Nacional da Educação (BRASIL, 2004) traz uma definição desse ensino:

$\S 1^{\circ}$ A Educação das Relações Étnico-Raciais tem por objetivo a divulgação e produção de conhecimentos, bem como de atitudes, posturas e valores que eduquem cidadãos quanto à pluralidade étnico-racial, tornando-os capazes de interagir e de negociar objetivos comuns que garantam, a todos, respeito aos direitos legais e valorização de identidade, na busca da consolidação da democracia brasileira. (BRASIL, 2004, p. 31).

Segundo o documento, esse reconhecimento das questões étnico-raciais, no que tange à educação, implica justiça e igualdade de direitos civis, sociais, culturais e econômicos, 
assim como a valorização dos diferentes grupos que compõem a sociedade brasileira, com vistas a desconstruir o mito da democracia racial que propaga a crença de que, se as/os negras/os não ocupam devidamente os espaços privilegiados da sociedade, isso se deve à falta de competência ou interesse, sem levar em consideração a hierarquia social que, durante séculos, vem trazendo prejuízo às/aos negras/os. Para mudar esse quadro, políticas públicas educacionais de reparação e de reconhecimento são necessárias para fomentar programas de ações afirmativas a fim de corrigir desigualdades raciais e sociais, bem como, desvantagens e marginalização criadas e mantidas por estrutura social excludente e discriminatória (BRASIL, 2004, p. 12). Trata-se de medidas que preveem, assim como a Constituição Federal ${ }^{17}$ em seu Art. $3^{\circ}, \mathrm{IV}$, "promover o bem de todos, sem preconceitos de origem, raça, sexo, cor, idade e quaisquer outras formas de discriminação".

Nesse sentido, educar em prol das relações étnico-raciais envolve tratar de "ensinos e de aprendizagens, é tratar de identidades, de conhecimentos que se situam em contextos de culturas, de choques e trocas entre jeitos de ser e viver, de relações de poder" (SILVA, 2007). Assim,

\begin{abstract}
para reeducar as relações étnico-raciais, no Brasil, é necessário fazer emergir as dores e medos que têm sido gerados. É preciso entender que o sucesso de uns tem o preço da marginalização e da desigualdade impostas a outros. E então decidir que sociedade queremos construir daqui para frente. [...] Assim sendo, a educação das relações étnico-raciais impõe aprendizagens entre brancos e negros, trocas de conhecimentos, quebra de desconfianças, projeto conjunto para construção de uma sociedade justa, igual, equânime. (BRASIL, 2004, p. 14).
\end{abstract}

Dessa maneira, "a luta pela superação do racismo e da discriminação racial é, pois, tarefa de todo e qualquer educador, independentemente do seu pertencimento étnico-racial, crença religiosa ou posição política" (BRASIL, 2004, p. 16).

A educação das relações étnico-raciais traz consequências não apenas para as/os negras/os, na valorização da sua descendência, mas também para as/os brancas/os, no reconhecimento da importância das/os negras/os e sua contribuição nos diversos aspectos da cultura brasileira. Dessa forma,

pedagogias de combate ao racismo e a discriminações elaboradas com o objetivo de educação das relações étnico/raciais positivas têm como objetivo fortalecer entre os

\footnotetext{
${ }^{17}$ Disponível em: $<$ http://www.planalto.gov.br/ccivil_03/constituicao/constituicaocompilado.htm>. Acesso em: 16 nov. 2016, 22:24:35.
} 
negros e despertar entre os brancos a consciência negra. Entre os negros, poderão oferecer conhecimentos e segurança para orgulharem-se da sua origem africana; para os brancos, poderão permitir que identifiquem as influências, a contribuição, a participação e a importância da história e da cultura dos negros no seu jeito de ser, viver, de se relacionar com as outras pessoas, notadamente as negras. (BRASIL, 2004, p. 16).

A escola ganha, portanto, papel primordial e central na busca pela eliminação de preconceitos e desigualdades de qualquer natureza social, pois ela possibilita o acesso a conhecimentos específicos além do convívio de sujeitos dotados de múltiplas identidades sociais. A sala de aula possibilita discussão e reflexão de questões que estão enraizadas na sociedade e que precisam ser revistas urgentemente para que tenhamos uma nação mais igual e democrática. Cabe à escola se posicionar politicamente contra toda forma de discriminação.

Moita Lopes (2012) aponta que a modernidade e os processos de colonização legitimaram certos modos de vida social referente ao gênero, à sexualidade, à raça, à etnia etc., negligenciando outros. Segundo o autor, aprendemos e continuamos a propagar discursos preconceituosos que invalidam outras formas de vida que são naturalizadas devido à repetição desses discursos ao longo dos séculos. Para ele, a dificuldade de tratar de tais temas advém do fato de que as/os próprias/os professoras/es foram formadas/os dentro desses discursos como também pelo fato de que os assuntos das salas de aula, como sujeito, tempos verbais etc. não focalizam a vida social. Dessa forma, abordagens focando o uso da língua ou o envolvimento das/os alunas/os na construção de significados se voltam para "significados pasteurizados" que não se relacionam com a vida social, sendo, portanto, simplesmente exercícios de "brincar de usar a linguagem" (MOITA LOPES, 2012, p. 12).

Ou seja, não basta que os documentos oficiais reconheçam a importância de trabalhar com temas de esferas mais amplas da sociedade. Também não é suficiente que esses temas estejam presentes nos livros didáticos, é preciso refletir criticamente sobre eles. Não basta reconhecer as diferenças raciais, étnicas e de gênero das/os nossas/os alunas/os, é necessário discutir as relações de poder entre elas, suas implicações na sociedade. Para isso, é fundamental que professoras/es estejam devidamente preparadas/os para atuar criticamente e se posicionar diante de possíveis discursos preconceituosos que possam surgir em sala de aula.

No capítulo a seguir, apresento a metodologia usada para a elaboração desta pesquisa. 


\section{METODOLOGIA}

Este capítulo apresenta os elementos metodológicos norteadores do processo investigativo e nele justifico as escolhas feitas a fim de responder às perguntas de pesquisa que orientam o estudo (cf. capítulo 1).

Este capítulo consta, em um primeiro momento, dos fundamentos metodológicos da abordagem qualitativa e dos princípios norteadores da pesquisa-ação. Em um segundo momento, apresento o contexto da pesquisa e as/os participantes. Finalmente, passo a abordar os instrumentos de pesquisa e os procedimentos para a discussão dos dados.

\subsection{A pesquisa qualitativa}

Ao ingressar no mestrado, busquei desenvolver uma pesquisa que trouxesse uma perspectiva social para as minhas aulas. Ao desenvolver uma abordagem que se voltava para a reflexão de questões sociais e relações de poder, meu objetivo era repensar as práticas sociais e proporcionar, nas aulas de língua francesa, momentos de reflexão sobre situações que estão presentes no dia a dia das/os alunas/os, aliando língua e sociedade, como prevê o letramento crítico. Assim, poderíamos almejar novas perspectivas para o cenário da educação brasileira, ao estimular a reflexão para a formação de cidadãs/os críticas/os capazes de atuarem em prol da igualdade de gênero, raça/etnia, classe etc. Assim, decidi desenvolver um ensino dentro da perspectiva crítica no qual eu pudesse estar presente e participar de todo o processo da pesquisa.

Buscando compreender como as/os participantes desta pesquisa entendem a dinâmica das identidades sociais de gênero e raça/etnia e como o LC pode propiciar a interação e a problematização dessas identidades na aula de línguas, favorecendo a formação cidadã, optei por desenvolver uma pesquisa qualitativa, pois, segundo Denzin e Lincoln (2006), a pesquisa qualitativa abarca uma abordagem naturalista de interpretação do mundo, em que as/os pesquisadoras/es fazem pesquisa em cenários naturais, buscando entender ou interpretar os fenômenos além dos significados que as pessoas conferem a eles. A pesquisa qualitativa exige "uma partilha densa com pessoas, fatos e locais que constituem objetos de pesquisa, para extrair desse convívio os significados visíveis e latentes que somente são perceptíveis a uma atenção sensível” (CHIZZOTTI, 2011, p. 28). 
A abordagem qualitativa busca descrever e compreender a dinâmica dos contextos sociais pesquisados, neste caso, a sala de aula de língua francesa, por meio do convívio com as pessoas que se encontram nesse contexto. Como afirma Flick (2009), a subjetividade da/o pesquisador/a, bem como das/os pesquisadas/os, tornam-se parte do processo de pesquisa. As reflexões das/os pesquisadoras/es sobre sua observação em campo, suas percepções, sentimentos etc., são dados em si mesmos. Para o autor,

\footnotetext{
a pesquisa qualitativa não se refere apenas ao emprego de técnica e de habilidade aos métodos, mas inclui também uma atitude de pesquisa específica. Essa atitude está associada à primazia do tema sobre os métodos, à orientação do processo de pesquisa e à atitude com que os pesquisadores deverão alcançar seus "objetivos". (FLICK, 2009, p. 36).
}

Assim, o autor situa a pesquisa qualitativa na análise de casos concretos dentro de suas peculiaridades locais e temporais, a partir das atividades e expressões das pessoas dentro de um contexto. Dessa forma, a pesquisa qualitativa torna-se estratégica para traçar caminhos e concretizar tendências, preservando a flexibilidade necessária em relação a seus objetos e tarefas.

A abordagem qualitativa contempla, portanto, os objetivos desta pesquisa sobre identidades sociais, bem como a problematização e a (re)construção dessas identidades dentro do contexto natural da sala de aula de língua francesa, uma vez que envolve a minha subjetividade como professora-pesquisadora, bem como a das/os participantes, buscando, como menciona Bortoni-Ricardo (2008), compreender e interpretar os fenômenos sociais de um contexto, bem como a maneira como as/os autoras/es sociais percebem e interpretam esses fenômenos.

\subsection{A pesquisa-ação}

Conforme já foi exposto no capítulo 2 , me alinho à concepção de língua como prática social (FAIRCLOUGH, 2008) imbricada de ideologias e relações assimétricas de poder (THOMPSON, 1990; FERREIRA, 2012; MOITA LOPES, 2012). Dessa forma, as identidades sociais de gênero e raça/etnia, que são o foco desta pesquisa, são construídas na e pela língua dentro de práticas sociais discursivas específicas de um determinado grupo social. 
Realizar uma pesquisa que visa problematizar questões sociais em sala de aula me leva automaticamente a refletir sobre a minha prática pedagógica. Implica encarar meus medos, reconhecer minhas falhas e limitações. Ao repensar minhas ações em sala de aula, há o desejo de mudança e de transformação dessa prática a fim de contribuir para a educação do nosso país e vislumbrar um ensino de línguas mais problematizador e transgressivo.

Com base nisso, ancoro-me nos pressupostos metodológicos da pesquisa-ação (P-A), que busca desenvolver uma prática crítico-reflexiva com a participação direta da/o pesquisador/a e das/os participantes na pesquisa. Além disso, ela apresenta caráter intervencionista de transformação social, indo ao encontro da educação como prática da liberdade proposta por Paulo Freire (2011), bem como do LC que demanda participação crítica dos sujeitos na percepção da sua própria realidade social.

Nesse sentido, Franco (2005) ressalta que a P-A é um procedimento essencialmente pedagógico e político com característica social que pode ter como objetivos a compreensão das práticas. Para tanto, é necessário levar em consideração os novos elementos que podem surgir durante o processo, influenciados pela própria pesquisa. Dessa maneira, não é possível controlar o que acontece na P-A, devido à imprevisibilidade nas ações a serem tomadas.

Assim, pesquisa e ação caminham juntas na busca pela transformação das práticas pedagógicas. A/O professor/a-pesquisador/a mergulha na "práxis do grupo social em estudo" (FRANCO, 2005, p. 486) de forma crítica e colaborativa a fim de gerar um processo de reflexão dessas práticas. Trata-se de uma busca pelo conhecimento pautado na "pedagogia de mudança da práxis" (FRANCO, 2005, p. 490), ou seja, um conhecimento que visa aprimorar as ações em sala de aula. Para isso, a voz dos sujeitos, suas perspectivas e pontos de vista, são essenciais, não apenas para fins de registro e posterior interpretação, mas para a composição dos processos de investigação.

Buscando encontrar alternativas para discutir e refletir sobre as construções sociais das identidades de gênero e raça/etnia na sala de aula de francês língua adicional, encontrei, nas perspectivas críticas de línguas, bem como na P-A, um possível caminho para desenvolver esse ensino.

Moita Lopes (1996) lembra que as pesquisas em sala de aula de línguas tendem a enfatizar o papel da/o professor/a-pesquisador/a que se envolve na investigação crítica da sua própria prática. Para o autor, essa tendência, chamada de P-A, pode ser compreendida de duas maneiras: “a) como uma maneira privilegiada de gerar conhecimento sobre a sala de aula, devido à percepção interna do processo que o professor tem; e b) como uma forma de avanço educacional, já que envolve o professor na reflexão crítica do seu trabalho" (MOITA LOPES, 
1996, p. 89). O autor acredita que esse tipo de pesquisa será cada vez mais realizado por professoras/es a fim de contribuir para a teorização do processo de ensino e aprendizagem de línguas, além de se encontrarem mais presentes nos cursos de formação de professoras/es que investigam as práticas de ensinar e aprender línguas.

Barbier (2007) define a P-A como pesquisa-ação existencial que privilegia temas ligados à afetividade humana e se caracteriza como "uma arte de rigor clínico, desenvolvida coletivamente, com o objetivo de uma adaptação relativa de si ao mundo" (BARBIER, 2007, p. 67). Segundo o autor, a arte, na P-A, diz respeito à sua inserção no domínio da intuição, da criação e da improvisação, além do seu sentido ambivalente e ambíguo.

A P-A enfatiza o caráter subjetivo da/o pesquisador/a que está presente na pesquisa "com todo o seu ser emocional, sensitivo, axiológico", bem como com o seu ser "dubidativo, metódico, crítico, mediador, enquanto pesquisador profissional” (BARBIER, 2007, p. 69). Ela reconhece o rigor da dialética da/o pesquisador/a que "articula constantemente a implicação e o distanciamento, a afetividade e a racionalidade, o simbólico e o imaginário, a mediação e o desafio, a autoformação e a heteroformação, a ciência e a arte" (BARBIER, 2007, p. 18). Isso se torna relevante nesta pesquisa uma vez que a minha subjetividade enquanto professorapesquisadora, minhas emoções e meus valores interferem na maneira como vejo e entendo as práticas sociais, logo, na maneira como me posiciono em sala de aula. Assim, minhas múltiplas identidades fazem parte do processo de pesquisa, influenciando no modo como interpreto as situações e os eventos ocorridos nesse contexto de ensino.

Essa metodologia leva ainda a/o pesquisador/a a lançar novos olhares sobre a complexa realidade investigada. Nesse sentido, Barbier (2007, p. 14) ressalta que a P-A leva a/o pesquisador/a a implicar-se, ou seja, a engajar-se no ambiente social no qual está inserida/o, levando as/os outras/os a se engajarem igualmente no processo da pesquisa. Assim, a/o pesquisador/a entende "que não se trabalha sobre os outros, mas e sempre com os outros" (BARBIER, 2007, p. 14). Desse modo, me sinto totalmente inserida nesta pesquisa, com todo o meu emocional me levando a perceber a realidade complexa da sala de aula com outros olhares e perspectivas. Ao mesmo tempo, busco levar minhas/meus alunas/os a perceber as relações de poder que envolvem as identidades sociais, compreendendo como elas se encontram na sociedade e a maneira como as relações sociais foram construídas historicamente. Dessa forma, estou subjetivamente envolvida na pesquisa, visando trabalhar com minhas/meus alunas/os em busca de um ensino transgressivo e útil para suas vidas em sociedade. 
Portanto, a metodologia da P-A vem ao encontro dos objetivos desta pesquisa que busca possíveis caminhos para problematizar e questionar as construções das identidades sociais de gênero e raça/etnia, trazendo um olhar mais político para o ensino da língua francesa e aprimorando as práticas pedagógicas da sala de aula. Para esse fim, foi fundamental a participação ativa das/os alunas/os nesse processo de problematização, pois suas opiniões me auxiliaram no planejamento das aulas, bem como na preparação das atividades de intervenção que foram desenvolvidas durante o semestre, buscando a melhor maneira de abordar esses temas em sala de aula e de conduzir as discussões.

\subsection{O contexto da pesquisa}

A pesquisa foi desenvolvida na Aliança Francesa de Brasília, escola na qual atuei há mais de 3 anos. Trata-se de uma instituição formada por associações sem fins lucrativos que difunde o conhecimento do francês como língua de oportunidade e de cultura além de enfatizar sua importância para o desenvolvimento profissional e pessoal. A pedra fundamental da AF foi lançada no dia 25 de agosto de 1959 com a presença do então presidente Juscelino Kubitschek e do ministro da Cultura da França, André Malraux, meses antes da inauguração da nova capital do país.

A escola se encontra em um bairro prestigiado de Brasília com habitantes de classes média e alta, tendo em vista o padrão socioeconômico do Estado do DF. Ela funciona nos três turnos, com aulas das $7 \mathrm{~h}$ às $22 \mathrm{~h}$. As/Os professoras/es e estudantes contam com salas de aula equipadas com mapas e quadros que retratam traços das culturas francesa e francófona, além de diversos recursos de multimídias, como computador, tela de projeção, projetor e aparelhos de DVD e CD player. A escola conta ainda com uma sala equipada com um quadro interativo, uma midiateca com livros, jornais, revistas, histórias em quadrinhos, CDs, DVDs etc., tudo na língua francesa, oferecendo maior suporte pedagógico para professoras/es e alunas/os. Inclusive há uma exigência da escola de que as aulas sejam ministradas em francês e que as/os alunas/os se expressem, preferencialmente, em francês na sala de aula. Portanto, nesta pesquisa, busco favorecer o uso da língua-alvo durante as interações.

A instituição promove ainda programas culturais como palestras, exposições, cursos, filmes, shows, dentre outros, para divulgar, sobretudo, eventos ligados às culturas francesa e francófona, incentivando uma imersão na língua, não apenas para alunas/os e professoras/es, como também para a comunidade. 
Vale ressaltar que a instituição mantém um acordo de cooperação técnica com a SEEDF desde 1966 que prevê que professoras/es servidoras/es da rede pública de ensino sejam lotadas/os na instituição sem nenhuma troca financeira. Em contrapartida, a escola oferece vagas para alunas/os e servidoras/es da rede pública de ensino. Logo, há uma grande diversidade social e racial em sala de aula, tendo em vista que alunas/os da própria instituição e da rede pública compartilham o mesmo espaço e interagem na aprendizagem da língua francesa, algo significativo para favorecer a imersão social e discutir questões identitárias tão presentes na sociedade, mas que, muitas vezes, não são devidamente questionadas.

Com base na realidade encontrada nesse contexto de ensino e aprendizagem do francês, pedi à direção da escola permissão para assumir uma turma no primeiro semestre de 2016. Contudo a turma ainda pertencia à outra professora, minha colega da SEEDF, pois retirar uma turma do quadro significaria deixar uma turma a menos para as/os professores da $\mathrm{AF}$, afetando seus salários. Na intenção de evitar qualquer desentendimento, decidimos, a diretora, o coordenador pedagógico e eu, que ela continuaria mantendo essa turma, me auxiliando no que fosse necessário, enquanto eu seria a responsável pelas aulas.

A pesquisa foi desenvolvida do dia $1^{\circ}$ de março ao dia 28 de junho. Tivemos um total de trinta e duas aulas, das quais três correspondiam a testes escritos e orais organizados pela própria instituição. Duas dessas aulas foram ministradas pela professora regente da turma, uma vez que não pude comparecer devido a compromissos do mestrado. As aulas tinham duração de 1 h40 com uma pausa de 10 minutos geralmente após 1 h de aula. Os encontros ocorriam às terças e quintas-feiras das $16 \mathrm{~h} 00$ às $17 \mathrm{~h} 50$.

O livro didático usado em sala foi o Amis et compagnie 4 da Editora CLE International. Trata-se de um livro voltado para pré-adolescentes e adolescentes a partir de 11 anos e que foi adotado pelas Alianças Francesas do Brasil para trabalhar com esse públicoalvo. O conteúdo do semestre era composto por 6 unidades que retratavam a cultura de alguns países que têm a língua francesa como língua materna ou como língua estrangeira privilegiada. Dentre eles, encontram-se a Bélgica (Unidade 1), a Suíça (Unidade 2), a Romênia (Unidade 3), o Vietnã (Unidade 4) e Madagascar (Unidade 5). A Unidade 6 trazia algumas celebridades de origem francesa e francófona.

\subsubsection{As/Os participantes}


No primeiro semestre de 2016, assumi uma turma de adolescentes de nível intermediário de francês na AF de Brasília. A turma era composta por 6 meninas e 7 meninos em uma faixa etária variando entre 14 e 17 anos de idade.

$\mathrm{Na}$ tabela a seguir, elenco os dados das/os participantes em maiores detalhes. Vale ressaltar que os nomes são fictícios e foram escolhidos por elas/es mesmas/os:

Tabela 1 - Perfil das/os participantes da pesquisa ${ }^{18}$

\begin{tabular}{|c|c|c|c|c|c|c|c|}
\hline Nome & Nacionalidade & Idade & Sexo & Cor/Raça & Cidade & Escola & Ano \\
\hline $\begin{array}{c}\text { Alexandre } \\
\text { Agrigento }\end{array}$ & Portuguesa & 15 anos & $\mathrm{M}$ & Branca & Lago Sul & Privada & Nono \\
\hline Anna W & Brasileira & 15 anos & $\mathrm{F}$ & Branca & Asa Sul & Privada & Segundo \\
\hline Biel & Brasileira & 15 anos & $\mathrm{M}$ & Parda & Sobradinho & Pública & Primeiro \\
\hline Cléo & Brasileira & 15 anos & $\mathrm{F}$ & Branca & Guará & Privada & Primeiro \\
\hline Johnson & Brasileira & 16 anos & $\mathrm{M}$ & Parda & Samambaia & Privada & Terceiro \\
\hline José & Brasileira & 14 anos & $\mathrm{M}$ & Branca & Sudoeste & Privada & Nono \\
\hline Lara & Brasileira & 16 anos & $\mathrm{F}$ & Branca & Asa Norte & Pública & Segundo \\
\hline Lauren & Brasileira & 15 anos & $\mathrm{F}$ & Branca & Samambaia & Privada & Primeiro \\
\hline Lenor & Portuguesa & 16 anos & $\mathrm{F}$ & Branca & Lago Sul & Privada & Primeiro \\
Estevão & Brasileira & 17 anos & $\mathrm{M}$ & Amarela & Lago Oeste & Pública & Terceiro \\
\hline Manoca & Brasileira & 16 anos & $\mathrm{F}$ & Outro & Lago Sul & Privada & Segundo \\
\hline Roberta & Brasileira & 16 anos & $\mathrm{M}$ & Parda & Lago Oeste & Pública & Segundo \\
\hline Robervaldo & Brasileira & 16 anos & $\mathrm{M}$ & Branca & Asa Sul & Privada & Segundo \\
\hline Washington & & &
\end{tabular}

No início do semestre havia 16 alunas/os matriculadas/os. Com a organização de horários, típica no início dos semestres letivos, 5 alunas/os saíram. Os alunos Robervaldo e Manoca entraram na turma posteriormente, nos dias 05/04/16 e 12/05/16 respectivamente, e concordaram em participar da pesquisa, ficando, no total, 13 alunas/os participantes. Desses, 9 são oriundos de escolas privadas e 4 da rede pública de ensino por meio do convênio com a SEEDF. A turma foi escolhida devido ao nível da língua e à quantidade relativamente equilibrada de alunas/os pagantes e da SEEDF. O objetivo era possibilitar problematizar mais profundamente sobre as identidades de gênero e raça/etnia além de verificar se havia diferenças na maneira como as/os alunas/os da rede pública e privada visualizavam e compreendiam a dinâmica dessas identidades. Contudo, com a saída de algumas/uns, não foi possível manter o mesmo equilíbrio.

Dentre as/os alunas/os, 11 eram brasileiras/os. Lenor Estevão e seu irmão Alexandre Agrigento eram portugueses. Algumas/ns já se conheciam por ter estudado juntas/os no

\footnotetext{
${ }^{18} \mathrm{Na}$ tabela 1, utilizo as siglas $\mathbf{M}$ para masculino e $\mathbf{F}$ para feminino. $\mathrm{O}$ termo Cidade diz respeito à cidade onde as/os participantes moram. O Ano se refere ao ano escolar no qual elas/es se encontram matriculadas/os.

19 O aluno Manoca não era asiático, mas se identificou assim no questionário inicial (cf. apêndice 1).
} 
semestre anterior. Desde o início, elas/es se mostraram favoráveis à pesquisa e foram bastante participativas/os durante as atividades desenvolvidas ao longo do semestre.

\subsection{Atividades desenvolvidas nas aulas}

Durante as aulas, ao longo do trabalho com o livro didático, desenvolvi um total de dez atividades: cinco relativas às identidades de gênero e cinco sobre as identidades de raça/etnia, sobretudo, interseccionadas com as de gênero. Ao final de cada uma, foi entregue um questionário para que as/os participantes pudessem expressar suas opiniões e sentimentos sobre a atividade desenvolvida. Os questionários foram preenchidos em português. Inicialmente, a ideia era que tais questionários fossem feitos em casa. Contudo, ao entregar o primeiro deles, apenas três alunas/os me entregaram-no devidamente respondido na aula seguinte. Em vista disso, percebi que o questionário deveria fazer parte da aula e, se possível, ser feito logo após as discussões, pois, em casa, elas/es acabam por não fazer. Assim, quando não havia tempo hábil para preencherem-no, elas/es expressaram suas opiniões oralmente. Suas falas e opiniões e foram gravadas.

$\mathrm{Na}$ tabela a seguir, é possível encontrar as atividades desenvolvidas com seus respectivos temas e datas. Além disso, especifico em quais atividades apliquei os questionários, bem como a quantidade de participantes presentes em cada uma delas:

Tabela 2: Atividades desenvolvidas durante as aulas

\begin{tabular}{|l|c|c|c|}
\hline \multicolumn{1}{|c|}{ Atividades/Temas } & Data & Questionário & Participantes \\
\hline Atividade 1: Dia internacional da mulher & $08 / 03 / 16$ & Não & 15 \\
\hline Atividade II: Feminicidio & $17 / 03 / 16$ & Sim & 12 \\
\hline $\begin{array}{l}\text { Atividade III: Vantagens e desvantagens de ser } \\
\text { homem e mulher na sociedade }\end{array}$ & $22 / 03 / 16$ & Sim & 10 \\
\hline $\begin{array}{l}\text { Atividade IV: Desigualdades entre homens e } \\
\text { mulheres }\end{array}$ & $03 / 05 / 16$ & Sim & 6 \\
\hline Atividade V: O que é o gênero? & $12 / 05 / 16$ & Não & 10 \\
\hline $\begin{array}{l}\text { Atividade VI: } \text { Representações de mulheres } \\
\text { brancas e negras }\end{array}$ & $17 / 05 / 16$ & Sim & 10 \\
\hline $\begin{array}{l}\text { Atividade VII: Ser mulher negra no Brasil } \\
\text { Atividade VIII: O racismo à brasileira }\end{array}$ & $31 / 05 / 16$ & Sim & 12 \\
\hline Atividade IX: O racismo cotidiano & $07 / 06 / 16$ & Não & 10 \\
\hline $\begin{array}{l}\text { Atividade X: } \text { A representação da mulher negra } \\
\text { nas capas de revista }\end{array}$ & $14 / 06 / 16$ & Não & 12 \\
\hline
\end{tabular}


Ao preparar as atividades, sempre que possível, buscava desenvolvê-las partindo do livro didático. Assim, procurava ter um olhar atento para as práticas sociais ali presentes, questionando e problematizando as identidades. Contudo, caso o livro não abordasse, naquele momento, temas que envolviam questões de gênero e raça/etnia, que são o foco desta pesquisa, eu elaborava atividades à parte com base em situações da realidade contemporânea. Tais atividades são entendidas, neste trabalho, como atividades que favoreçam a interação entre as/os alunas/os e a professora-pesquisadora, possibilitando refletir sobre a nossa realidade por meio do questionamento das práticas sociais.

Sei que o letramento crítico não se trata de um método, mas de uma postura, de uma atitude a se ter em sala de aula. Isso requer uma mudança em toda a minha prática pedagógica, na forma como leciono, inclusive com o próprio livro didático, na forma como percebo as identidades construídas nesse material, como as/os alunas/os utilizam a linguagem para construir identidades, posicionando a si mesmas/os e as/os outras/os nesse contexto de aprendizagem. Essa perspectiva de ensino demanda conhecimento teórico e, sobretudo, sensibilidade para propiciar a reflexão sobre os discursos preconceituosos, estereotipados e cristalizados que impedem outras formas de vida. Portanto, a minha sala de aula deve ser aberta ao diálogo e à construção do conhecimento ativo por parte das/os estudantes. Da mesma forma, a minha postura como educadora deve ser crítica e atenta a essas questões em todo o processo de ensino e aprendizagem, não apenas nos momentos em que as atividades são desenvolvidas.

Na seção a seguir, apresento os instrumentos utilizados nesta pesquisa.

\subsection{Os instrumentos de pesquisa}

No que tange aos dados desta pesquisa, recorro a Resende (2008) ao dizer que eles não foram simplesmente coletados como se já estivessem disponíveis para a/o pesquisador/a, mas sim gerados com objetivos específicos para a pesquisa. Nesse sentido, a autora afirma que

ir a campo e realizar interações especificamente organizadas para a pesquisa não é coletar algo que já esteja disponível na vida social, pois o que fazemos é criar situações, gerar espaços de interlocução e, muitas vezes, criar métodos para isso. Investigamos problemas soc]iais sem dúvida pré-existentes à pesquisa, mas criamos situações sociais úteis para sua investigação. (RESENDE, 2008, p. 82-83). 
Dessa forma, os dados desta pesquisa foram gerados uma vez que, segundo a mesma autora, não existiriam fora do contexto da pesquisa. Para a geração dos dados, visando melhor alcançar os objetivos previstos no capítulo 1, foram utilizados os seguintes instrumentos: gravação em áudio, questionários semiabertos, produções escritas, diário da professorapesquisadora e caderneta. Os dados gerados pelos três primeiros instrumentos, também chamados de dados primários, foram os mais utilizados. Já os dados gerados pelo diário da professora-pesquisadora e pela caderneta são considerados dados secundários por terem sido menos utilizados nesta pesquisa.

A seguir, apresento, em maiores detalhes, os instrumentos utilizados para geração dos dados.

\subsubsection{Gravação em áudio}

Tendo em vista os objetivos desta pesquisa, foi primordial registrar as interações ocorridas em sala de aula. Dessa forma, todas as aulas foram gravadas em áudio para poder ter acesso às interações das/os participantes no momento de discutir os dados. Segundo Lüdke e André (2013), a gravação em áudio permite registrar todas as expressões orais, possibilitando à/ao pesquisador/a maior liberdade para prestar atenção na/o entrevistada/o. Por meio desse sistema, obtém-se um registro naturalista dos eventos além de tornar a documentação de dados independente das perspectivas da/o pesquisador/a e das/os participantes (FLICK, 2009).

\subsubsection{Questionários}

Nesta pesquisa foram entregues os questionários relativos às atividades de intervenção, um questionário inicial e um questionário final.

O questionário inicial (cf. apêndice 1) revelou-se importante para a investigação preliminar da pesquisa. Ele fez uso de perguntas abertas e fechadas acerca das/os participantes: idade, sexo, cor/raça, escola onde estudam etc. Além disso, as últimas perguntas se voltam para o ensino do francês com temas sociais.

Ao final de cada atividade, foi entregue um questionário para que as/os alunas/os pudessem expressar suas opiniões a respeito da atividade desenvolvida além de destacarem seus sentimentos sobre a experiência de aprender francês com os temas discutidos. Ao longo 
do semestre, fui alterando os questionários, visando ter diferentes informações das/os alunas/os (cf. apêndices 2, 3, 4 e 5).

Ademais, foi entregue o questionário final (cf. apêndice 6) a fim de ter as opiniões das/os aluna/os sobre o semestre como um todo. Ele apresentou duas questões: 1) Como você descreveria as aulas de francês desse semestre? 2) O que ficou dessas aulas? O que você vai levar para a sua vida?

\subsubsection{Produções Escritas}

Ao longo do semestre, foram propostas duas produções escritas (cf. apêndices 7 e 8), a primeira com o tema: "A construção do gênero feminino e masculino na sociedade: origem e consequências" e a segunda sobre: "As desigualdades entre mulheres brancas e negras no Brasil: quais origens, consequências e possíveis soluções?”.

O objetivo dessas produções era ter acesso às percepções das/os participantes sobre as identidades sociais de gênero e raça/etnia durante a pesquisa, analisando os possíveis desdobramentos das discussões em sala de aula para a (re)construção dessas identidades, bem como para a agência das/os alunas/os ao procurarem por outras fontes de informação que abordassem os temas debatidos em sala. Além disso, eu buscava analisar ainda de que maneira a prática pedagógica do letramento crítico poderia contribuir para a formação de cidadãs/os mais críticas/os e conscientes da sua realidade.

\subsubsection{Diário da professora-pesquisadora}

Para fins de registro das minhas percepções, sentimentos e emoções, escrevi, no final de cada aula, informações que pudessem auxiliar para uma melhor compreensão dos eventos ocorridos em sala. Segundo Flick (2009), o diário da/o pesquisador/a torna-se útil para a pesquisa, uma vez que ele permite documentar a aplicação do método, a abordagem de campo, as experiências, as dificuldades encontradas no campo ou no contato com as/os entrevistadas/os. O autor complementa afirmando que o diário de pesquisa permite que a/o pesquisador/a de fato possa captar o comportamento cotidiano nas situações naturais, servindo também à reflexão sobre o processo de pesquisa.

\subsubsection{Caderneta}


Segundo Barbier (2007), a/o pesquisador/a mantém consigo uma caderneta para anotações a fim de registrar dados imediatamente. Assim, para fins de registros gerais, mantinha comigo um caderno no qual pudesse anotar ideias que surgiam durante o processo de realização da pesquisa. Além disso, anotava minhas ansiedades e preocupações na preparação das aulas e das atividades, bem como minhas inquietações no desenrolar da pesquisa. Ademais, procurava registrar o que achava interessante das conversas e reflexões que tinha com a minha orientadora.

\subsection{A ética na pesquisa qualitativa}

O paradigma da pesquisa qualitativa demanda preocupações com a produção do conhecimento, com a compreensão dos significados e com a qualidade dos dados, tendo a confiança, a responsabilidade, a veracidade, a qualidade, a honestidade e a respeitabilidade, no lugar da busca da riqueza ou do poder, como valores essenciais (CELANI, 2005).

A autora complementa que a pesquisa deve evitar danos e prejuízos às/aos participantes, como também para as/os pesquisadoras/es e para a sociedade em geral. Ela alerta para o fato de que, na pesquisa educacional, é imprescindível levar em consideração as relações assimétricas de poder, o papel das/os participantes como também a responsabilidade social.

Ao relatar sobre a dificuldade de um planejamento prévio dentro do paradigma qualitativo, Celani (2005, p. 110) ressalta ainda que a proteção das/os participantes é essencial. Logo,

(...) é indispensável o consentimento informado, esclarecido, na forma de diálogo contínuo e a reafirmação de consentimento ao longo da pesquisa. Este diálogo possibilitará ao pesquisador certificar-se de que os participantes entenderam os objetivos da pesquisa, ao mesmo tempo que deixa clara a esses a liberdade que têm de desistir de sua participação a qualquer momento.

Para realização desta pesquisa, levei em consideração tais questões éticas. Tive o consentimento informado da direção da AF de Brasília, que me autorizou a utilizar o nome da escola (cf. apêndice 9). Pedi ainda o consentimento das/os participantes e das/os suas/seus responsáveis para a realização da pesquisa (cf. apêndice 10), consentimento esse que foi renovado durante o semestre. $\mathrm{O}$ Termo de consentimento foi entregue às/aos participantes no 
dia 08/03/16 tendo em vista que algumas/uns alunas/os sinalizaram, no primeiro dia de aula, a possibilidade de ter que mudar de turma por questão de horário. O nome das/os participantes também foi preservado por meio de pseudônimos escolhidos por elas/es próprias/os. Uma vez finalizada a dissertação, darei um retorno às/aos professoras/es da escola por meio de uma formação pedagógica sobre o estudo desenvolvido. Além disso, enviarei, por e-mail, a dissertação às/aos participantes da pesquisa.

Tendo em vista a sua responsabilidade social, esta pesquisa buscou, portanto, resguardar o seu caráter ético, uma vez que foi desenvolvida em um contexto social onde as/os participantes interagiram em relações assimétricas de poder.

\subsection{Os procedimentos para discussão dos dados}

Para discussão dos dados, utilizei o método interpretativista para buscar os sentidos construídos socialmente pelas/os alunas/os no uso da linguagem, uma vez que a pesquisa qualitativa interpretativista é um tipo de investigação que depende da definição e da redefinição das/os observadoras/es a respeito dos significados do que veem e ouvem. (STAKE, 2011).

Ao tratar da pesquisa interpretativista na Linguística Aplicada, Moita Lopes (1994) ressalta que o ponto de vista dos sujeitos é essencial, tendo em vista que a existência do mundo social depende da existência do ser humano. Dessa forma, o acesso à realidade se dá pela interpretação dos significados construídos pelas/os participantes nela inseridas/os. O autor entende a linguagem como construção social, um modo particular de organizar a experiência humana através do discurso. Com base nessa concepção de linguagem, a perspectiva de pesquisa utilizada aqui está aliada aos pressupostos teóricos que embasam este estudo.

Optei por trabalhar sob a perspectiva da pesquisa interpretativista, pois ela vai ao encontro do proposto pela P-A que busca melhor compreender a realidade que nos cerca. Vale ressaltar que, diferente dos demais autores, Barbier (2007) desenvolve a P-A alicerçado na teoria da complexidade de Edgar Morin (2011). Barbier enfatiza o caráter complexo da realidade social que está imbricada de relações lógicas impossíveis de serem desconstruídas em unidades isoladas. A realidade é complexa porque é multifaceta, não podendo ser separada. O mesmo ocorre com o ser humano que é complexo e apresenta inúmeras identidades. Nas palavras de Barbier (2007, p. 87), ele é "uma totalidade dinâmica, biológica, psicológica, social, cultural, cósmica, indissociável”. Assim, para ter conhecimento de uma 
realidade ou de um fenômeno, é preciso ver as múltiplas faces que o compõe. Minhas interpretações foram, portanto, uma maneira de ver e interpretar a realidade, de construir sentidos a partir da minha subjetividade.

Moita Lopes (1994) ressalta ainda que o acesso aos significados se dá pela utilização de diversos instrumentos de pesquisa, cabendo à/ao pesquisador/a selecionar os dados que melhor ilustrem sua interpretação. A partir dos instrumentos utilizados na pesquisa, é possível fazer a triangulação dos dados, Segundo Flick (2009, p. 361), a triagulação "é utilizada para designar a combinação de diversos métodos, grupos de estudo, ambientes locais e temporais e perspectivas teóricas distintas para tratar de um fenômeno".

Nesse sentido, a abordagem qualitativa interpretativista se adéqua perfeitamente a esta pesquisa, tendo em vista que, ao estudar os construtos das identidades sociais, é necessário lançar mão de diversas fontes de dados para ter acesso aos sentidos dos eventos, além de poder descrever e interpretar os significados que as/os participantes dão a eles. Dessa forma, os dados apresentados nesta pesquisa refletem a minha interpretação, uma maneira de entender os significados construídos pelas/os alunas/os de língua francesa participantes desta pesquisa.

Entendo que os mesmos fenômenos poderiam ser interpretados de maneira diferente, pois a minha subjetividade interfere na maneira como percebo e interpreto a dinâmica social das interações discursivas em sala de aula. Portanto, tendo em vista o paradigma da abordagem qualitativa interpretativista, não busco aqui um método a ser seguido. Meu objetivo se volta para o processo da pesquisa em si, na problematização e na possível (re)construção das identidades sociais de gênero e raça/etnia dentro do LC, buscando compreender como as/os participantes entendem e interpretam essas identidades, além de favorecer a formação de cidadãs/os mais críticas/os e reflexivas/os. Esta pesquisa se constitui, portanto, em um dos muitos meios possíveis de trabalhar identidades sociais na sala de aula de francês como língua adicional.

No capítulo a seguir, faço a discussão dos dados tendo em vista as perguntas de pesquisa explanadas no primeiro capítulo. 


\section{DISCUSSÃO DOS DADOS}

Neste capítulo, faço a discussão dos dados com o objetivo de responder às perguntas de pesquisa. A fim de obter maiores detalhes dos eventos ocorridos em sala, do desenvolvimento das aulas e das atividades de intervenção, bem como dos posicionamentos e reações das/os alunas/os ao longo das discussões, selecionei momentos das interações que se mostraram relevantes não apenas para responder às perguntas de pesquisa, mas também para melhor compreensão do contexto de ensino. Tendo em vista não ser possível analisar todas as aulas, selecionei apenas aquelas nas quais foram desenvolvidas as atividades de intervenção.

As transcrições foram feitas na língua utilizada pelas/os alunas/os no momento da discussão, sem nenhuma alteração gramatical. As interações feitas em francês foram traduzidas por mim e colocadas logo após o diálogo original.

Nas traduções, prezo pelo sentido do enunciado, fazendo, caso necessário, as devidas alterações gramaticais. Os enunciados ou palavras sublinhadas indicam que a/o participante fez uso do português naquele momento da interação. Já as palavras ou enunciados mantidos em francês se encontram em itálico para fins de melhor compreensão do diálogo.

Utilizo o termo Élèves (Alunas/os) quando as/os alunas/os falam ao mesmo tempo e me identifico como Professeure (Professora) tendo em vista ser esse o vocativo frequentemente utilizado ao se referirem a mim. Vale ressaltar que os nomes das/os participantes foram alterados por seus respectivos pseudônimos. As análises foram feitas por ordem cronológica dos encontros.

Este capítulo está dividido em três seções: na primeira seção, encontra-se a discussão dos dados gerados nas aulas em que foram desenvolvidas as atividades de intervenção, juntamente com os questionários das atividades. A segunda seção corresponde à discussão dos dados das produções escritas. Na terceira seção, faço a discussão dos dados do questionário final.

\subsection{Discussão das atividades de intervenção e dos questionários das atividades}

Nesta seção, discuto os dados gerados nas aulas das atividades de intervenção e nos questionários das atividades, buscando observar os discursos e os posicionamentos das/os participantes nos eventos mencionados. 


\subsubsection{Aula 1: $1^{\circ}$ de março de 2016 - primeiros contatos}

Na primeira aula havia 12 alunas/os presentes. Na primeira parte da aula, a professora regente da turma passou um vídeo sobre a escola AF de Brasília e outro que retratava os principais clichés e estereótipos franceses. Nesse momento, não participei efetivamente da aula, fiquei apenas observando a reação das/os alunas/os.

Após a pausa, me apresentei à turma e expliquei sobre a minha pesquisa de mestrado, os objetivos e a importância de um ensino que se volte para questões e problemas da sociedade.

A fim de melhor exemplificar a proposta da pesquisa e verificar o entendimento das/os alunas/os no que tange ao construto do gênero, mostrei uma questão da prova do ENEM de 2015 que trazia a célebre frase de Simone de Beauvoir "ninguém nasce mulher, torna-se mulher” (2009, p. 9). A maioria delas/es não conhecia a filósofa. Após trazer algumas reflexões sobre a autora, perguntei o que haviam entendido do enunciado. Poucas/os souberam explicar o sentido que ele trazia. Para minha surpresa, Alexandre Agrigento e Cléo disseram que o gênero é diferente do sexo de uma pessoa, revelando um possível entendimento de gênero como construção social. Não aprofundei no assunto devido ao tempo da aula, mas perguntei se gostariam de ter outras aulas nessa perspectiva, discutindo questões de gênero e raça/etnia, ao que responderam afirmativamente.

Fiquei muito animada com o interesse das/os alunas/os em participar da pesquisa. No dia anterior às aulas, eu estava muito apreensiva, pensava em suas reações, se iriam gostar da proposta da pesquisa e dos temas. Imaginei que teria maior aceitação daquelas/es provenientes da rede pública, por estarem, a meu ver, mais envolvidas/os com questões sociais. Nesse sentido, a aluna Cléo, em especial, me surpreendeu por sua empatia e seu entusiasmo em discutir questões sociais em sala de aula. Por ser uma aluna branca e oriunda de uma das escolas particulares mais renomadas de Brasília, não esperava tamanha aceitação. Isso nos mostra que, mesmo sem querer, fixamos identidades o tempo todo e "etiquetamos" nossas/os alunas/os por classe social, raça, gênero etc. Na minha concepção, eu teria maiores dificuldades de aceitação por parte das/os alunas/os de escola privada, pois presumi que gostariam de trabalhar com conteúdos gramaticais ou algo ligado a questões cognitivas de aprendizagem. Por serem escolas que, de maneira geral, privilegiam o conteúdo, não imaginava ter pessoas interessadas em questões sociais.

Nesta aula, desenvolvi uma atividade com elas/es (cf. apêndice 11) para conhecêlas/os melhor, mas senti certa insegurança das/os alunas/os para se expressarem. 
Possivelmente minha identidade de pesquisadora estaria impondo resistência naquele espaço. Diante disso, conversei com a professora regente explicando que, para que a pesquisa se desenvolvesse de maneira adequada, era preciso que eu assumisse as aulas naquele semestre. Felizmente, a professora sempre se mostrou muito solícita e disposta a ajudar e disse que eu podia fazer o que fosse melhor para a pesquisa. Daí em diante, assumi a turma como professora-pesquisadora.

Gostaria de compartilhar com a/o leitor uma inquietação que tive nesse dia. Ao final da aula, conversando com a professora regente sobre a turma, ela fez um comentário que me deixou um pouco apreensiva. Aqui destaco o que escrevi no meu diário desse dia:

\footnotetext{
Ao conversar com a professora regente, ela me passou algumas informações sobre as/os alunas/os. Ela comentou que o nível de língua delas/es era fraco, tanto nas habilidades orais quanto nas escritas e que falavam muito em português nas aulas. Isso me deixou um pouco preocupada, pois, nesta pesquisa, busco refletir e discutir com as/os alunas/os sobre questões de gênero e raça/etnia. Inclusive a turma foi escolhida também devido ao nível linguístico-discursivo delas/es para que pudéssemos problematizar essas questões de maneira mais detalhada. (DIÁRIO DA PROFESSORA-PESQUISADORA, $1^{\circ}$ de março de 2016).
}

Tendo em vista esse contexto, na seção a seguir, passo a discutir os dados gerados nesta pesquisa.

\subsubsection{Aula 3: 08 de março de 2016}

Nesta aula, por ser o dia internacional da mulher, decidi trazer algumas reflexões sobre as conquistas femininas e sua importância para a sociedade contemporânea, sobretudo para a vida das mulheres. O objetivo da aula era verificar as percepções das/os alunas/os sobre esse dia, como também sobre o feminismo. Para tanto, em um primeiro momento, busco uma reflexão sobre as manifestações e lutas feministas, bem como o sentido de comemorar o dia internacional da mulher. Posteriormente, busco refletir sobre o feminismo, seus objetivos e ideais. Finalmente, trago novamente a autora Simone de Beauvoir (2009) a fim de pensarmos sobre o conceito de gênero como construção social.

Nesta aula, desenvolvi a primeira atividade cuja análise encontra-se a seguir.

\subsubsection{Atividade I: Dia internacional da mulher}


A fim de ter a percepção das/os alunas/os sobre o dia internacional da mulher, pergunto sobre o porquê de haver esse dia e o que ele representa. Lauren cita o caso das mulheres que foram assassinadas em um incêndio, fazendo referência ao incêndio na fábrica de tecidos em Nova York em 1911. Discutimos brevemente sobre esse e outros episódios que fazem referência ao dia da mulher.

As/os alunas/os tiveram dificuldades em expressar o sentido e a relevância desse dia na vida das mulheres. Refletimos, então, sobre o papel da mulher na sociedade atual, sobre as discriminações e violências que ainda atingem inúmeras delas no mundo todo, bem como sobre as conquistas feministas por igualdade de direitos sociais e políticos.

Posteriormente, passamos a discutir sobre o feminismo que se destacou com as lutas das mulheres por melhores condições sociais e pelo direito ao voto. O objetivo era buscar ter acesso às suas percepções sobre o movimento. No excerto selecionado a seguir, é possível encontrar um momento da interação ${ }^{20}$ :

\section{Interação 1:}

Professeure : Quand on parle de la journée de la femme, on parle de féminisme. Oui ? Qu'est-ce que c'est le féminisme?

Élèves : C'est l'égalité... (...)

Professeure : Et quel type d'égalité ?

Élèves : Sociale, politique, économique...

Professeure : Exactement. Donc quand on parle de féminisme on parle justement de ça. (...) On lutte pour une égalité des droits sociaux. Parce qu'il y a des gens qui pensent que le féminisme c'est le contraire du machisme.

Cléo : Oui.

Professeure : Oui ? Parce que... Qu'est-ce que c'est le machisme ?

Alexandre Agrigento : L'affirmation de l'homme.

Professeure : L'affirmation de l'homme. L'homme a plus de pouvoir que la femme. Donc l'homme est ici [mostrando um patamar superior] et la femme est ici [mostrando um patamar inferior]. Ok? Le féminisme, ce n'est pas ça.

Cléo : O contrário é femismo.

\section{Interação 1 - Tradução:}

Professora: Quando falamos do dia internacional da mulher, falamos de feminismo. O que é o feminismo?

Alunas/os: É igualdade.

Professora: E que tipo de igualdade?

Alunas/os: Social, política, econômica...

Professora: Exatamente. Então, quando falamos de feminismo, falamos justamente disso. (...) Lutamos por uma igualdade de direitos sociais. Porque tem pessoas que acreditam que o feminismo é o contrário do machismo.

Cléo: Sim.

Professora: Sim? Porque... O que é o machismo?

Alexandre Agrigento: A afirmação do homem.

\footnotetext{
${ }^{20}$ Uso aqui o termo interação para subdividir e organizar numericamente os diálogos registrados durante as aulas.
} 
Professora: A afirmação do homem. O homem tem mais poder que a mulher. Então o homem está aqui [mostrando um patamar superior] e a mulher está aqui [mostrando um patamar inferior]. Ok? O feminismo não é isso.

Cléo: $\underline{O}$ contrário é femismo.

$\mathrm{Na}$ interação 1, as/os alunas/os trazem aspectos sociais, políticos e econômicos de igualdade, demonstrando ter uma percepção diferente da do senso comum, que tende a conceber o feminismo como uma superioridade do sexo feminino. Aqui, é possível observar que as/os alunas/os demonstram ter consciência da busca pela igualdade de direitos sociais. A partir do posicionamento de Alexandre Agrigento, procurei esclarecer a diferença entre o machismo e o feminismo que busca a igualdade entre os gêneros.

Com a discussão, foi possível perceber que elas/es não entendiam o feminismo como a superioridade da mulher, mas como igualdade social, política e econômica entre os gêneros. Nesse momento, Cléo se posiciona, enfatizando que, quando se busca uma superioridade feminina, deixa de ser feminismo e passa a ser femismo ${ }^{21}$. Tal colocação foi uma contribuição significativa não apenas para as/os alunas/os, mas também para mim, pois nenhum de nós havia ouvido falar do termo. De fato, Cléo demonstra ser uma aluna bastante atenta para questões sociais. Isso foi possível perceber desde o primeiro dia da pesquisa no qual ela se mostrou bastante receptiva ao tema.

Após termos refletido rapidamente sobre o feminismo, perguntei se elas/es se consideravam feministas. Poucas/os se manifestaram, sobretudo os meninos. Apenas dois deles levantaram a mão. Imagino que a pouca manifestação da turma se deu devido ao pouco conhecimento sobre o feminismo. Visando refletir com elas/es sobre os objetivos do movimento, mostrei o teste: Você é feminista? (cf. apêndice 12). O teste foi feito por Cynthia Miramis, doutoranda em direito na Universidade Federal de Mato Grosso, a fim de facilitar o acesso a informações sobre o feminismo. Ele apresenta 10 questões sobre os direitos sociais das mulheres no que diz respeito ao salário, ao voto, ao trabalho doméstico, aos estudos, dentre outros. Questionei se elas/es concordavam que as mulheres deviam ter os mesmos direitos que os homens. Todas/os disseram que sim. Solicitei que cada aluna/o lesse uma pergunta e refletimos juntos.

Feito isso, disse que, se elas/es haviam respondido afirmativamente à maioria das questões, elas/es podiam se considerar feministas. Ao perguntar novamente quem havia

\footnotetext{
${ }^{21} \mathrm{O}$ femismo "pode ser considerado o sinônimo do machismo (ao mesmo tempo que é seu oposto), pois se trata de uma ideologia de superioridade da mulher sobre o homem. O femismo, assim como o machismo, prega a construção de uma sociedade hierarquizada a partir do gênero sexual; baseada em um regime matriarcal". Disponível em: < https://www.significados.com.br/feminismo/>. Acesso em: 11 set. 2016, 23:09:54.
} 
respondido "sim" à maior parte das questões, todas/os se manifestaram e levantaram a mão, inclusive os meninos. Apesar de não ser possível comprovar, elas/es pareciam honestos em suas posições. Após a reflexão feita em sala, elas/es demonstraram compreender o sentido de ser feminista, percebendo que, não apenas as mulheres podem ser feministas, mas os homens também.

Prosseguimos debatendo o assunto e mostrei novamente a frase de Simone de Beauvoir que havia trazido na primeira aula. Como não tínhamos tido tempo de pensar sobre ela no dia, achei interessante trazê-la para esta aula:

\section{Interação 2:}

Professeure : On ne naît pas femme, on le devient. Qu'est-ce que ça veut dire ?

Cléo : Que o conceito de mulher é criado [inaudível]. Que a gente não nasce mulher, a gente vai pegando esses hábitos que a gente encontra e vive, em uma visão de sociedade.

\section{Interação 2 - Tradução:}

Professora: Não se nasce mulher, torna-se mulher. O que isso quer dizer?

Cléo: Que o conceito de mulher é criado [inaudível]. Que a gente não nasce mulher, a gente vai pegando esses hábitos que a gente encontra e vive, em uma visão de sociedade.

$\mathrm{Na}$ interação 2, Cléo demostra perceber o gênero como construção social. Cada sociedade constrói ao longo do tempo e do espaço, por meio da cultura, a noção de feminino e masculino. Nesse sentido, Joan Scott (1995) declara que o gênero é uma categoria social imposta sobre um corpo sexuado, ou seja, uma interpretação sobre o papel da mulher a partir do sexo. Nas palavras da autora, "o gênero é um elemento constitutivo de relações sociais baseado nas diferenças percebidas entre os sexos", bem como "uma forma primeira de significar as relações de poder" (SCOTT, 1995, p. 21). A autora traz aqui o conceito de gênero não apenas como categoria social importante para entender o lugar e o valor da mulher em uma determinada cultura, mas também uma ferramenta útil para estabelecer e compreender as relações de poder entre homens e mulheres.

Ao dizer que o processo de se tornar mulher provém de hábitos, Cléo expõe a relevância das "normas" sociais nessa construção. A esse respeito, Louro (2008) advoga que a construção do gênero se dá por meio de diversas aprendizagens e práticas culturais. Em seu texto, a autora questiona sobre as instâncias sociais que "têm o poder de decidir e inscrever em nossos corpos as marcas e as normas que devem ser seguidas" (LOURO, 2008, p. 18). 
Dentre elas, a autora cita a família, a igreja e a escola como instituições que ganham importante papel na construção do gênero.

Isso nos mostra que aprendemos a viver o gênero pela cultura, pelos discursos que se encontram na mídia e que são propagados por instituições sociais reconhecidas e legitimadas para ditar o que é "certo" e "errado", "bom" e "ruim". Esse entendimento também se afilia à perspectiva que aqui discuto sobre as práticas identitárias, segundo a qual as identidades são construídas nos discursos (FAIRCLOUGH, 2008).

Sendo assim, a norma não provém de uma única fonte, ela está em todo lugar, e se expressa "por meio de recomendações repetidas e observadas cotidianamente, que servem de referência a todos, ela "naturaliza"' (LOURO, 2008, p. 22). Ainda na visão da autora, ela é onipresente, presumida, tornando-se invisível e construindo a identidade valorizada. Assim, tudo o que dela se diferencia não tem reconhecimento.

Mais adiante, pergunto a diferença entre sexo e gênero e mais uma vez Cléo se posiciona:

\section{Interação 3:}

Professeure : Donc, quelle est la différence entre le sexe et le genre?

Cléo : O sexo é designado ao nascer, biologicamente. O gênero é com o qual você se identifica, pode ser binário ou não binário, ou seja, mulher, homem ou os dois ou nenhum [inaudível].

\section{Tradução:}

Professora: Então, qual é a diferença entre sexo e gênero?

Cléo: $\underline{O}$ sexo é designado ao nascer, biologicamente. O gênero é com o qual você se identifica, pode ser binário ou não binário, ou seja, mulher, homem ou os dois ou nenhum [inaudível].

Como pode ser visto na interação 3, Cléo entende o sexo como biológico, sendo, portanto, designado ao nascer. Já o gênero diz respeito à maneira como a pessoa se vê na sociedade, ou seja, o gênero com o qual ela se identifica. Interessante observar ainda que Cléo demonstra não perceber o gênero apenas como binário (masculino/feminino), mas nas suas múltiplas possibilidades. A esse respeito, Louro (2008) declara que, apesar de as normas sociais serem reiteradas ao longo do tempo pelas instâncias sociais, as formas de viver o gênero e a sexualidade se multiplicaram nos dias de hoje, não sendo mais possível pensar em sistemas binários: masculino/feminino, heterossexual/homossexual.

A autora destaca que as transformações são inerentes à história e à cultura de um povo, possibilitando novas formas de comportamento e maneiras de se relacionar capazes de subverter as fronteiras do sexo e do gênero e fazendo emergir novas identidades. Contudo, a 
autora afirma ainda que é importante considerar que essas novas identidades não são igualmente valorizadas, existem relações de poder entre elas, pois não estão livres dos valores culturais e sociais. Dessa forma, é possível perceber que, em um contexto de diversidade, as identidades que ali se encontram são reconhecidas de maneira diferente pela sociedade.

O objetivo dessa atividade era problematizar sobre o sentido do dia internacional da mulher. Esse dia busca o reconhecimento de todas/os a respeito das lutas e conquistas femininas, ou seja, uma reflexão sobre o que já foi conquistado e o que ainda precisa ser feito. O reconhecimento pode ganhar sentido de solidariedade diante da busca por igualdade social, econômica e política entre homens e mulheres. Nas interações 2 e 3, percebe-se que a participante Cléo demonstra entender o sexo como biológico e o gênero como construção social, ligado à maneira como a pessoa se identifica, indo além de composições binárias. Apenas Cléo se posicionou diante das minhas perguntas, trazendo suas percepções, o que possibilitou refletir sobre elas.

As discussões se deram, prioritariamente, em francês. Contudo Cléo se expressou especialmente em português. Mesmo assim eu mantive o francês, isto é, as línguas estavam em interação. As/os alunas/os se expressaram sobre uma temática importante em suas vidas no que diz respeito à construção de si mesmas/os. Com a minha fala, bem como a das/os colegas, elas/es tiveram acesso a discursos em francês sobre temas que, de maneira geral, não se encontram devidamente inseridos na sala de aula. Além disso, no momento de se expressarem, elas/es tiveram a oportunidade de expandir seus recursos linguístico-discursivos na língua, pois foi possível trabalhar o vocabulário relativo ao tema. Isso possibilita não apenas aperfeiçoar o conhecimento e a prática da língua francesa de maneira geral, mas, sobretudo, colocar em foco o porquê das práticas sociais, construindo, assim, novos conhecimentos de maneira reflexiva e dialógica. A tentativa foi trazer o ensino de línguas para uma perspectiva de letramento, não apenas ensinar a língua sem mostrar o quanto ela está atrelada às vivencias sociais das quais participamos.

No final da aula, falei um pouco mais sobre a pesquisa, os objetivos de propor reflexões críticas sobre temas sociais, não apenas devido ao fato de testes nacionais como o ENEM trazerem temáticas como essas, mas, principalmente, para a própria formação delas/es como seres humanos e cidadãs/os.

No final das reflexões, propus com as/os alunas/os desenvolver outras atividades abordando questões de gênero e, posteriormente, interseccionando-as com as de raça/etnia. Assim, acordamos que eu traria documentos que abordavam situações da contemporaneidade para serem discutidos em sala e que elas/es poderiam igualmente trazer casos para serem 
debatidos nas aulas. Como destaca Barbier (2007), essa negociação é primordial para o processo da pesquisa-ação na qual as ações são pensadas coletivamente. Como ainda não havia entregado o Termo de consentimento às/aos alunas/os uma vez que algumas/uns delas/es disseram que iriam ter que trocar de turma, o fiz nessa aula pedindo para entregaremno ao responsável por elas/es a fim de que pudessem se informar a respeito e, caso concordassem, autorizar a sua participação.

\subsubsection{Aula 6: 17 de março de 2016}

$\mathrm{Na}$ aula desse dia, havia 12 alunas/os em sala. O objetivo da lição presente no livro didático era apresentar uma música do cantor belga Jacques Brel. A música Madeleine, escrita nos anos 1960, conta a história de um homem que espera por uma mulher para um encontro, porém ela nunca aparece. Apesar disso, ele continua a esperar por ela todas as semanas no mesmo lugar, na esperança de que um dia ela possa vir encontrá-lo.

Com a música, o livro propunha descrever fisicamente e psicologicamente o personagem que espera por Madeleine a partir de alguns adjetivos listados. Diante disso, me veio à mente problematizar as atitudes do personagem, bem como os adjetivos usados para descrevê-lo, buscando trazer a situação elencada na música para a vida real das/os alunas/os, refletindo criticamente sobre as práticas sociais. Apesar de a música não fazer menção à violência contra a mulher, meu objetivo era partir dela para refletirmos sobre casos de feminicídio na sociedade brasileira. Assim, desenvolvi a Atividade II (cf. apêndice 13) que traz casos de feminicídio e busca refletir sobre os motivos que levam um homem a cometer homicídio contra uma mulher.

Na seção a seguir, faço a análise da referida atividade.

\subsubsection{Atividade II: Feminicídio}

A violência contra a mulher pode se dar de diferentes maneiras. Dentre elas, podemos destacar a violência psicológica, sexual e física, podendo chegar à sua expressão máxima: o feminicídio. Segundo o Mapa da Violência 2015 (BRASIL, 2015), nesse mesmo ano foi sancionada a Lei 13.104/2015, a Lei do Feminicídio, classificando-o como crime hediondo. De acordo com o documento, a Lei entende que há feminicídio "quando a agressão envolve violência doméstica e familiar, ou quando evidencia menosprezo ou discriminação à condição 
de mulher, caracterizando crime por razões de condição do sexo feminino" (BRASIL, 2015, p. 7).

Segundo o mesmo documento, o Sistema de Informações de Mortalidade da Secretaria de Vigilância em Saúde do Ministério da Saúde, entre 1980 e 2013 morreu, em um ritmo crescente, um total de 106.093 mulheres, vítimas de homicídio. Isso nos mostra que, no Brasil, o feminicídio ainda é uma das principais mortes de violência contra a mulher. Daí a importância de refletir sobre a temática em sala de aula, problematizando as práticas sociais.

Começamos a aula pela descrição das seguintes imagens presentes no livro didático:

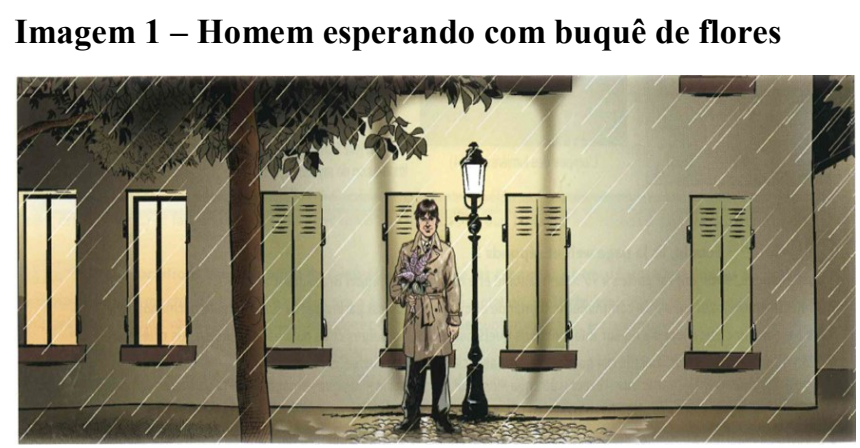

Fonte: Amis et compagnie 4, p. 6.

Imagem 2 - Homem correndo na chuva

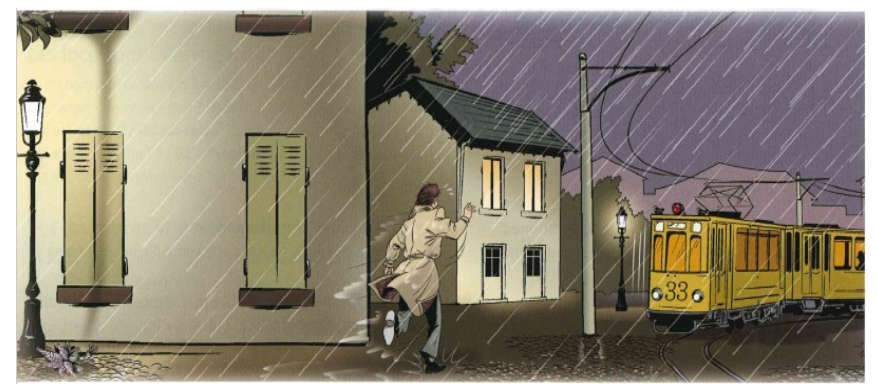

Fonte: Amis et compagnie 4, p. 7.

Solicitei que descrevessem o personagem das imagens, suas características físicas e que imaginassem o que estava acontecendo em cada uma delas. Ouvimos a música e perguntei o que tinham compreendido. Para a análise, dividi a turma em quatro grupos de três alunas/os tendo em vista que a música é composta por quatro estrofes (cf. apêndice 13). Cada grupo iria trabalhar uma estrofe. Solicitei que relessem a parte correspondente a cada grupo e que analisassem o que se passa na história, destacando os sentimentos e imaginando os pensamentos do personagem. Elas/es discutiram em francês. Após a análise da música com toda a turma, fizemos as atividades previstas no livro didático: 
Imagem 3 - Atividades propostas pelo livro didático: Jacques Brel e Madeleine

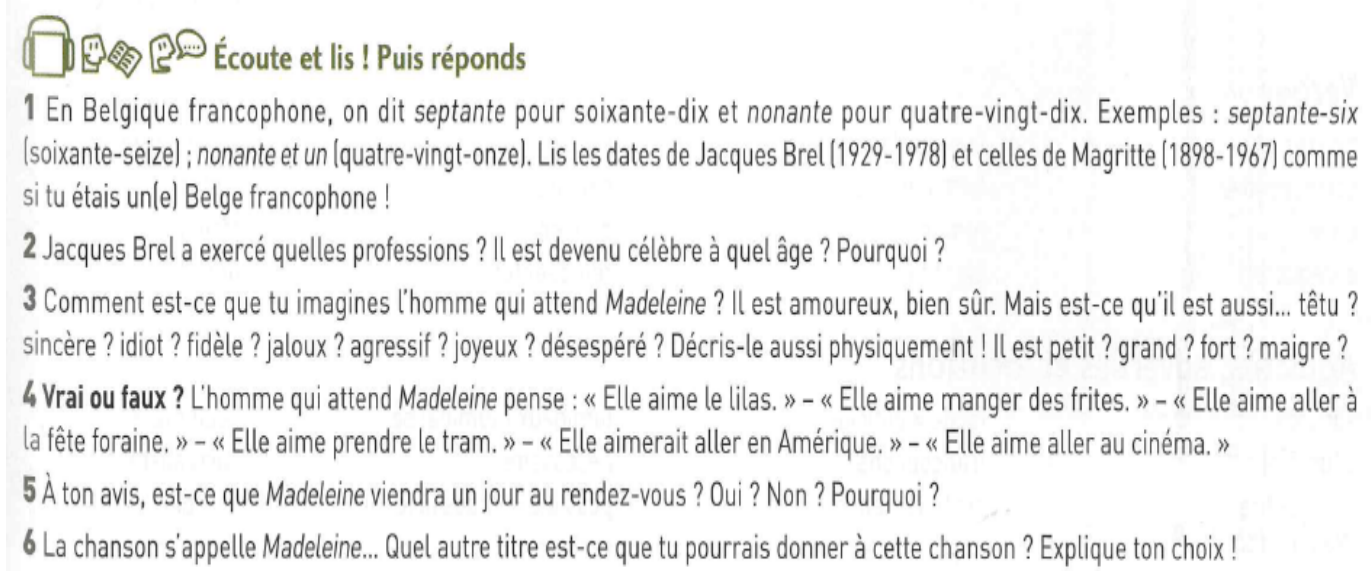

Fonte: Amis et compagnie 4, p. 7.

Como pode ser visto na imagem 3, o livro propunha, na atividade 3, que se imaginasse como seria o homem que espera por Madeleine. É possível encontrar adjetivos como: teimoso, sincero, idiota, fiel, ciumento, agressivo, feliz e desesperado. Além disso, é solicitado às/aos alunas/os uma descrição física do personagem, com adjetivos como pequeno, alto, forte e magro. A partir de então, propus uma reflexão sobre os adjetivos trazidos nesse material. O adjetivo "idiota" em especial chamou minha atenção: com base em que o livro teria proposto esse adjetivo para caracterizar o personagem? Por que sua atitude de esperar incansavelmente por Madeleine seria tão negativa? Caso o personagem fosse mulher, os adjetivos seriam os mesmos?

Diante disso, perguntei suas opiniões a respeito do personagem:

\section{Interação 4:}

Professeure : Qu'est-ce que vous pensez de cet homme? Il est normal ?

Élèves : Iludé... Drogas.

Washington : Il a des problèmes.

Lauren : Madeleine c'est un amie imaginaire.

Roberta : C'est un fatôme.

Professeure : C'est une amie imaginaire?

Élèves : Oui.

Lauren : C'est ça Madeleine.

Professeure : Donc il vit dans l'illusion...

Élèves : Oui.

Professeure : C'est un psychopathe?

Johnson : Sociopathe.

Professeure : Mais le sociopathe c'est différent, non? Qu'est-ce que c'est un sociopathe?

Johnson : Il est isolé de société. 
Professeure : Il est isolé de la société. Mais le sociopathe, il a une caractéristique bien fixe. Le sociopathe, il n'est pas sensible aux sentiments de l'autre, à l'émotion de l'autre. Si tu souffres, ça va. (...) Il est indifférent, il ne souffre pas.

Washington : C'est Madeleine.

Professeure : Il souffre ou non?

Élèves : Non.

Lauren : Oui, oui. Il a déprimé.

Professeure : Oui classe, il est triste, non?

Johnson : Donc il est psychopathe et Madeleine c'est sociopathe.

(...)

Professeure : Donc il souffre, vous remarquez qu'il souffre? Donc il n'est pas sociopathe.

Alexandre Agrigento : Il est romantique.

Anna W : Frouxo, frouxo, essa é a palavra.

José : il a de [inaudível].

Professeure : Il a de...

José : Espoir, esperança.

Interação 4 - Tradução:

Professora: O que vocês acharam desse homem? Ele é normal?

Alunas/os: Iludido... Drogas.

Washington: Ele tem problemas.

Lauren: Madeleine é uma amiga imaginária.

Roberta: É um fantasma.

Professora: É uma amiga imaginária?

Alunas/os: Sim.

Lauren: Essa é a Madeleine.

Professora: Então ele vive uma ilusão...

Alunas/os: Sim.

Professora: É um psicopata?

Johnson: Sociopata.

Professora: Mas o sociopata é diferente, não? O que é um sociopata?

Johnson: Ele é isolado da sociedade.

Professora: Ele é isolado da sociedade. Mas o sociopata, ele tem uma característica bem fixa. O sociopata, ele não é sensível aos sentimentos do outro, à emoção do outro. Se você sofre, tudo bem (...) Ele é indiferente, ele não sofre.

Washington: É Madeleine.

Professora: Ele sofre ou não?

Alunas/os: Não.

Lauren: Sim, sim. Ele está deprimido.

Professora: Sim, turma, ele está triste, não?

Johnson: Então ele é psicopata e Madeleine é sociopata.

(...)

Professora: Então, ele sofre, vocês percebem que ele sofre? Então ele não é sociopata.

Alexandre Agrigento: Ele é romântico.

Anna W: Frouxo, frouxo, essa é a palavra.

José: Ele tem [inaudível].

Professora: Ele tem...

José: Espoir, esperança.

$\mathrm{Na}$ interação 4, indago sobre as opiniões das/os alunas/os a respeito do personagem principal. Buscando problematizar, trago, inconscientemente, uma imagem pré-moldada de homem. Ao utilizar o termo "normal", fiz referência a um padrão de homem socialmente construído e aceito na sociedade. Uma referência a uma "norma" social, presumida, do que se esperar de um homem em uma situação como essa na qual a mulher não lhe corresponde. Fiz 
referência a um estereótipo que não prevê que um homem espere por uma mulher e que, caso o faça, não é bem visto pelas/os outras/os. Sem perceber, trouxe, na minha pergunta, um traço cristalizado do gênero masculino. Isso nos mostra que, por vivermos e sermos construídas/os em uma sociedade patriarcal que não ensina homens a esperarem por uma mulher, acabamos por trazer esses estereótipos, sem nem mesmo questioná-los. Tendo em vista a sua ratificação e cristalização na sociedade, eles se encontram, como nos afirma Louro (2008), invisíveis e onipresentes.

Como é possível perceber em suas respostas, as/os alunas/os corroboram a "norma" à qual fiz referência e, sem questionar o meu posicionamento, respondem que o personagem está iludido, tendo possíveis problemas com drogas. Seguindo o mesmo raciocínio, Lauren e Roberta parecem interpretar a ausência de Madeleine a uma possível não existência da personagem, como se não fosse concebível sua ausência no encontro. Da mesma forma, Washington parece entender a atitude de Madeleine como resultado de uma doença mental.

Em seu posicionamento, Johnson parece entender as atitudes de ambas/os as/os personagens como advindas de distúrbios mentais, provavelmente por não se encaixarem nos padrões de gênero da sociedade. Seu discurso corrobora a imagem do homem trazida pelo próprio livro didático por meio do adjetivo "idiota", uma vez que sua atitude foge da "norma" social prevista pelo gênero masculino do que um homem deveria ou não fazer nessa situação. Da mesma forma, ele parece entender, assim como Washington, a atitude de Madeleine como fora da "norma" do gênero feminino, pois, nesse caso, espera-se que uma mulher corresponda ao homem, indo ao encontro. Caso contrário, ela é vista como sociopata e ele como psicopata. Vale ressaltar que em nenhum momento foi colocado em questão o fato de Madeleine simplesmente não querer ir ao encontro. Seu poder de escolher com quem quer ou não sair não foi nem mesmo apontado pelas/o alunas/os, demonstrando que o empoderamento da mulher ainda não se encontra devidamente inscrito no imaginário coletivo correspondente ao gênero feminino.

Anna W também corrobora essa imagem e parece entender a atitude do personagem de forma negativa, ao dizer que ele é frouxo por esperar por uma mulher que não lhe corresponde. Por outro lado, Alexandre Agrigento e José trazem uma visão diferente da situação, não vendo problemas nas atitudes do personagem que, inclusive, é visto como romântico e esperançoso. Aqui, eles se reportam a outras imagens do gênero masculino, menos estereotipadas e cristalizadas.

Esses posicionamentos nos remetem, portanto, às imagens e percepções que as/os alunas/os têm das identidades de homem e de mulher na sociedade e o que se espera de cada 
um/a delas/es em um relacionamento. Do homem, espera-se uma atitude menos romantizada, por assim dizer. Esperar por uma mulher que não lhe corresponde não faz parte da "norma" social de ser homem, ou seja, daquilo que o gênero masculino construiu e atribuiu ao sexo. Nesse caso, o personagem é tido como iludido, drogado e até mesmo doente. Já da mulher, espera-se que ela corresponda ao homem e apareça ao encontro. Caso contrário, sua atitude é compreendida como uma doença mental. As/Os alunas/os trouxeram, portanto, imagens cristalizadas e naturalizadas dos gêneros. Apenas Alexandre Agrigento e José se voltaram para outras imagens menos estereotipadas.

Isso nos mostra que o comportamento de homens e mulheres na sociedade é fruto de um aprendizado sociocultural para que possamos agir segundo as prescrições de cada gênero, havendo, portanto, uma “expectativa social em relação à maneira como homens e mulheres devem andar, falar, sentar, mostrar seu corpo, brincar, dançar, namorar, cuidar do outro, amar etc.” (BRASIL, 2009, p. 40).

Após uma breve pausa, passamos para a segunda etapa da atividade que buscava refletir sobre dois casos de feminicídio ocorridos em Brasília recentemente. Para iniciar a interação, retomo a história da música e pergunto se "é comum a reação romantizada do homem de sempre esperar pela mulher de maneira otimista", ao que elas/es respondem que “não”. Pergunto “qual é, geralmente, a reação das pessoas diante de um ‘não' nessa situação”. Lauren diz que "a pessoa pode ficar contrariada". José diz que "ela pode ficar estressada" e, para Roberta, "agressiva”. Ao perguntar "que tipo de agressão pode ser feita", elas/es citam “agressão física e verbal". Nesse momento, elas/es comentam a respeito de um caso ocorrido na UnB na semana anterior à aula. Uma aluna foi morta no laboratório da universidade após ser dopada com clorofórmio.

Como havíamos mencionado rapidamente na aula anterior esse caso, decidimos discutir melhor sobre ele nessa aula. Assim, a fim de ter maiores detalhes, selecionei para a aula duas reportagens de jornal. Disse que as reportagens traziam casos de feminicídio. Perguntei o que era o feminicídio e Anna W disse ser "o assassinato de mulheres". Comentei rapidamente os casos selecionados e disse que iriam trabalhar em grupos. Dividi a turma em quatro grupos, ficando dois grupos com o mesmo caso. Ao ver a reportagem, João comentou que está em português. Justifico dizendo que, por se tratar de uma reportagem local, ela se encontra em português, mas que a discussão de ambos os casos seria feita em francês. Trouxe as reportagens para que tivessem mais detalhes dos casos e pudessem, posteriormente, contar aos colegas sobre o ocorrido. Após leitura e discussão em grupo, pedi que explicassem para toda a turma, em francês, o que haviam entendido das reportagens. 
Discutimos sobre os casos, os possíveis motivos que teriam levado os rapazes a cometerem feminicídio. O excerto abaixo nos traz, de forma mais clara, o diálogo em sala:

\section{Interação 5:}

Professeure : Classe, qu'est-ce qui mène un homme à rompre, à tuer une femme seulement parce qu'elle ne veut pas être avec lui ?

Lauren : É... Como é que fala fica?

Professeure : Fica em que sentido?

Lauren : Fica agressivo.

Professeure : Il devient agressif.

Lauren : Il devient agressif.

Professeure : Mais pourquoi il n'accepte pas?

Anna W : Il est descontrolé, il est crazy.

Élèves : [riem]

Professeure : Il est fou.

Anna W : Como se dit louco?

Professeure : Fou.

Anna W : Fou, fou.

Professeure : Mais donc vous pensez que tous les hommes qui tuent les femmes, c'est parce qu'ils sont fous?

Roberta : Covarde.

Professeure : Ils sont lâches [escrevendo no quadro]. (...) Donc, ce n'est pas simplement parce qu'ils sont fous, c'est parce qu'ils sont lâches. Et pourquoi ils n'acceptent pas un "non" ? Quel est le problème?

Luren : Parce que, ham, quer...

Professeure : Il veut...

Lauren : Il veut être... Como é que é?

Roberta : Ele se acha superior.

Professeure : Ah, ils se sentent supérieurs [escrevendo no quadro] à la femme, oui?

Lauren : Oui.

Professeure : Vous êtes d'accord? Alexandre Agrigento, tu voudrais dire quelque chose?

Alexandre Agrigento : Non, non, non.

Professeure : Et pourquoi ils se sentent supérieurs?

Johnson : Parce qu'il y a un sentiment de posse.

José : Machisme.

Interação 5 - Tradução:

Professora: Turma, o que leva um homem a romper, a matar uma mulher somente porque ela não quer ficar com ele?

Lauren: É.... Como é que fala fica?

Professora: Fica em que sentido?

Lauren: Fica agressivo.

Professora: Il devient agressif.

Lauren: Il devient agressif.

Professora: Mas por que ele não aceita?

Anna W: Ele é descontrolado. Ele é crazy.

Alunas/os: [riem]

Professora: Ele é louco.

Anna W: Como se diz louco?

Professora: Fou.

Anna W: Fou, fou.

Professora: Mas, então, vocês acham que todos os homens que matam uma mulher, é porque eles são loucos?

Roberta: Covarde. 
Professora: Eles são lâches [escrevendo no quadro]. (...) Então, não é simplesmente porque eles são loucos, mas porque eles são covardes. E por que eles não aceitam um "não"? Qual é o problema?

Lauren: Porque, ham, quer...

Professora: Ele quer...

Lauren: Ele quer ser... Como é que é?

Roberta: Ele se acha superior.

Professora: Ah, eles se acham supérieurs [escrevendo no quadro] à mulher, sim?

Lauren: Sim.

Professora: Vocês concordam? Alexandre Agrigento, você gostaria de dizer alguma coisa?

Alexandre Agrigento: Não, não, não.

Professora: E por que eles se sentem superiores?

Johnson: Porque tem um sentimento de posse.

José: Machismo.

$\mathrm{Na}$ interação 5, busco problematizar a reação violenta de um homem contra uma mulher. Lauren aponta a postura agressiva do homem, mas não explica o porquê da agressão. Buscando maiores detalhes, questiono novamente sobre o motivo da não aceitação. Anna W parece entender essa reação como um descontrole, uma espécie de doença sobre a qual o homem tem pouco ou nenhum poder, algo externo a ele. Isso nos remete, mais uma vez, à imagem de homem trazida na interação 4, na qual as/os alunas/os demonstram compreender o homem como psicopata. Anna W traz aqui uma percepção de identidade baseada no discurso do senso comum que tente a naturalizar a atitude violenta do homem, como se o fato de cometer tamanha violência contra uma mulher se devesse a uma loucura e não a um aspecto social.

Continuo questionando procurando desconstruir esse discurso e refletir sobre a construção do gênero na sociedade, que ainda ensina uma masculinidade fixada, com características estanques sobre os significados de se ser homem. Diante da minha posição, Roberta demonstra uma possível compreensão social do problema. Tal situação também pode ser encontrada nos posicionamentos de Lauren, Johnson e José que desconstroem e se opoem ao discurso que naturaliza a violência doméstica na sociedade.

Com base nisso, passamos a refletir sobre a importância da Lei Maria da Penha criada em 2006 para proteger mulheres da violência doméstica e familiar que ainda é a principal causa do feminicídio no Brasil. No final da aula, trouxe alguns dados de violência contra a mulher buscando um possível despertar para uma conscientização da nossa realidade.

\section{Interação 6:}

Professeure : Qu'est-ce que vous pensez de tout ça ? Quelle est votre opinion ? Où est le problème de notre société?

Anna W : C'est culturel. 
Alexandre Agrigento : C'est que pendant le temps, beaucoup de temps, nous avons une société patriarcale que por consequência aura le machisme. Ça c'est le problème, je pense.

Professeure : Vous pensez que notre société est machiste?

Élèves : Oui

Professeure : Pourquoi ?

Lauren : Parce que... Ham, je peux parler en portugais?

Professeure : Oui.

Lauren: É porque não tô inspirada mesmo. Tipo, porque nós meninas de 15, 14, 16 anos, não podemos usar o tipo de roupa que a gente quer porque os homens de 30 anos não conseguem parar de olhar. Então se você faz, pra qualquer pessoa, a culpa é da gente, porque a gente não deveria tá usando esse tipo de roupa, e não do cara. E vai continuar assim, se a culpa nunca for do cara.

Roberta: É tem pessoa que tipo, que fala que foi, tipo que foi estuprada, tipo ninguém acredita, tipo acha que você tá zoando.

Lauren: É [inaudível] roupa não é um convite. Tipo, posso mostrar o que eu quiser, eu não tô convidando você.

Lara: E também, tipo, acham que se a mulher é estuprada, a culpa ainda é dela que ela tava provocando, pergunta se ela não tentou fechar as pernas.

Johnson : Mas não adianta, quando o cara quer estuprar, e os estupradores mesmos eles gostam mais quanto mais a mulher não quer, quando ela tenta fugir e tudo mais.

(...)

Professeure : Vous pensez que quand une femme, elle est violée, c'est sa faute à elle?

Élèves : Non.

Alexandre Agrigento : Mais dépend de la situation, quer dizer, eu penso que não, mas pode haver uma situação... Por exemplo, quando uma mulher estupra um homem.

Professeure : Acontece.

Lauren: Mas ai a culpa já não é também do homem, ai já é da mulher, mudou o caso.

Professeure : C'est rare. C'est commun ce genre de chose?

Lauren : Acontece.

Johnson : Mas nos dois casos, a culpa nunca é da vítima, não tem como.

Lauren : A culpa nunca é da vítima.

Interação 6 - Tradução:

Professora: O que vocês acham disso? Qual é a opinião de vocês? Onde está o problema da nossa sociedade?

Anna W: É cultural.

Alexandre Agrigento: É que durante um tempo, muito tempo, nós temos uma sociedade patriarcal que, por consequência, terá o machismo. Esse é o problema, eu acho.

Professora: Vocês acham que nossa sociedade é machista?

Alunas/os: Sim.

Professora: Por quê?

Lauren: Porque... Ham, eu posso falar em português?

Professora: Sim.

Lauren: É porque não tô inspirada mesmo. Tipo, porque nós meninas de 15, 14, 16 anos, não podemos usar o tipo de roupa que a gente quer porque os homens de 30 anos não conseguem parar de olhar. Então se você faz, pra qualquer pessoa, a culpa é da gente, porque a gente não deveria tá usando esse tipo de roupa, e não do cara. E vai continuar assim, se a culpa nunca for do cara.

Roberta: É tem pessoa que tipo, que fala que foi, tipo que foi estuprada, tipo ninguém acredita, tipo acha que você tá zoando.

Lauren: É [inaudível] roupa não é um convite. Tipo, posso mostrar o que eu quiser, eu não tô convidando você.

Lara: E também, tipo, acham que se a mulher é estuprada, a culpa ainda é dela que ela tava provocando, pergunta se ela não tentou fechar as pernas.

Johnson: Mas não adianta, quando o cara quer estuprar, e os estupradores mesmos eles gostam mais quanto mais a mulher não quer, quando ela tenta fugir e tudo mais.

(...)

Professora: Vocês acham que quando uma mulher é violentada, é culpa dela?

Alunas/os: Não.

Alexandre Agrigento: Mas depende da situação, quer dizer, eu penso que não, mas pode haver uma situação... Por exemplo, quando uma mulher estupra um homem. 
Professora: Acontece.

Lauren: Mas ai a culpa já não é também do homem, ai já é da mulher, mudou o caso.

Professora: É raro. É comum esse tipo de coisa?

Lauren: Acontece.

Johnson: Mas nos dois casos, a culpa nunca é da vítima, não tem como.

Lauren: A culpa nunca é da vítima.

$\mathrm{Na}$ interação 6, Anna W parece desnaturalizar o comportamento do homem atribuindo-o a uma construção social e não a uma "loucura" como citado na interação 5. Da mesma forma, Alexandre Agrigento ressalta a influência da sociedade patriarcal na construção dessas práticas, sociedade esta que insiste em colocar e manter o homem em uma situação de superioridade à mulher, tanto física quanto socialmente.

Diante do meu questionamento sobre a sociedade machista, Lauren se posiciona. Na sua fala, percebo certo desabafo. Ao trazer um relato sobre a realidade de garotas da sua idade, que não têm poder de escolha sobre o próprio corpo, imagino que ela mesma se inclui na situação narrada. Roberta concorda com o comentário de Lauren e declara que, mesmo nos casos em que a menina diz ter sido estuprada, ninguém acredita nela e pior, ainda a julgam e a culpam. É o que pode ser visto no comentário de Lara que ressalta o julgamento da sociedade na busca por um culpado, um motivo para o ato ter acontecido.

De fato, a mulher ainda é vista como culpada pelo seu próprio estupro. É a chamada cultura do estupro, uma violência simbólica que se exerce por meio dos discursos e das práticas sociais. Tal violência consiste em encontrar justificativas para o estupro, estimulandoo e reforçando a tolerância dessa prática. Dessa forma, mulheres tendem a ser culpabilizadas por suas roupas, atitudes e comportamentos. Uma grande consequência disso é que elas tendem a acreditar que são, de fato, culpadas e, quando não, encontram inúmeros obstáculos ao denunciar o estuprador. Após vencerem o medo e as torturas psicológicas, ainda acontece de verem a violência sofrida ser minimizada por policiais das delegacias, sobretudo, as que não são preparadas para lidar com esses tipos de caso ${ }^{22}$.

Apesar dos raros casos em que uma mulher violenta um homem sexualmente, as/os alunas/os parecem perceber o estupro como algo que advém do próprio estuprador e não da vítima, demonstrando relativa consciência da realidade no que tange à violência sexual.

Quanto à língua, as discussões foram feitas, prioritariamente, em francês. Apenas nos cinco minutos finais da aula, eles usaram o português. No momento de se expressar sobre o machismo na sociedade, Lauren traz um possível relato da sua própria realidade. A meu ver, o

\footnotetext{
${ }^{22}$ Disponível em: $<$ http://www.bbc.com/portuguese/noticias/2015/12/151209_obstaculos_violencia_mulher_rm $>$. Acesso em: 21 dez. 2015, 18:23:34.
} 
uso da língua portuguesa aqui se deve não apenas a uma possível falta de recursos linguísticos capazes de organizar o discurso da forma como ela deseja, mas também por uma questão de identidade. Aprendemos a falar e expressar nossos sentimentos na língua materna, pois nela as palavras ganham sentidos, levando consigo emoções. Ao concebermos a outra língua como estrangeira, como algo que não nos pertence, passamos a vê-la como algo exterior a nós. Dessa forma, posso falar essa língua, mas ela não fala por mim, pois nem sempre revela índices da minha identidade.

Concordo com Almeida Filho (2013) quando diz que, ao longo do tempo, essa nova língua vai construindo a/o própria/o aprendiz. Nas palavras do autor, ela vai não apenas ser falada futuramente, em momentos autênticos, mas vai ainda "'falar esse mesmo aprendiz', revelando índices da sua identidade e das significações próprias do sistema dessa língua-alvo" (ALMEIDA FILHO, 2013, p. 20). Em outras palavras, ao longo do tempo, a língua passa a ser usada para expressar emoções e traços identitários da/o aluna/o. Porém, para que isso aconteça, é preciso prática, é preciso possibilitar momentos de discussão sobre temas de interesse das/os educandas/os para que possam, aos poucos, usar a língua para expressar suas opiniões e sentimentos.

Nessa atividade, todas/os estavam muito participativas/os, atentas/os e interessadas/os em se expressar. Ao final da aula, foi entregue o questionário da Atividade II (cf. apêndice 2) para ser feito em casa. Contudo, na aula seguinte, apenas três alunas/os me entregaram-no devidamente respondido. No questionário, destaco alguns comentários: Lenor Estevão relata ter gostado muito da atividade. Para ela "acho que é importante discutir acerca destas coisas e de dar e receber mais informação acerca delas". Ela afirma ainda que "é comum não poder falar acerca disto na sala de aula e então é bom ter uma oportunidade para fazer isso nas aulas de francês".

Para Biel, a aula "foi muito educativa e importante, pois falou sobre coisas que estão se tornando cada vez mais comuns em nossa sociedade, o feminicídio e o feminismo". Para ele, "essas aulas estão nos ajudando a pensar e discutir melhor sobre tais assuntos e por isso são muito importantes em nosso curso". Da mesma forma, José afirma ter se sentido "muito confortável e alegre por discutir sobre esse tema em sala, pois são assuntos importantes para a vida".

Diante dos comentários, é possível perceber que as/os alunas/os se sentiram confiantes e confortáveis para expressar suas opiniões. Elas/es demonstraram valorizar discutir temas sociais em sala de aula e se mostram interessadas/os por estar debatendo assuntos presentes no seu dia a dia, bem como na sociedade em geral. As interações propiciaram reflexões, 
favorecendo novos aprendizados que vão além da língua por si mesma, mas se servindo dela para pensar e tomar consciência das suas próprias realidades, como prevê Freire (2011).

Vale ressaltar ainda que essa atividade foi desenvolvida a partir de um documento presente no próprio livro didático, mostrando que, mesmo seguindo o livro, é possível ir além. Foi uma possibilidade encontrada aqui para trazer o LC para a aula de francês a fim de problematizar as identidades sociais de gênero, questionando a violência contra a mulher.

Um dos desafios que encontrei durante a preparação das aulas, foi justamente trazer essas questões para sala de aula e ao mesmo tempo seguir o livro didático. Tendo em vista que temos um conteúdo a ser cumprido e que, muitas vezes, o livro não prevê problematizar os textos nele encontrados, é preciso formação docente adequada que possibilite desenvolver um olhar crítico e sensível para observar os discursos presentes nesse material e proporcionar uma reflexão sobre as identidades e situações que ele traz para sala de aula. Dessa forma, podemos agir, como ressalta Duboc (2015), nas brechas da sala de aula, ou seja, nas possibilidades que temos, bem como nas oportunidades que surgem em sala, pois os materiais com os quais trabalhamos trazem diversas identidades sociais que estão, muitas vezes, repletas de visões do senso comum. Elas, porém, podem ser úteis à medida que trazem os estereótipos à tona e permitem que sejam problematizados.

\subsubsection{Aula 7: 22 de março de 2016}

Como já havia terminado a $1^{\mathrm{a}}$ lição do livro e na aula seguinte seria feriado, decidi não começar a $2^{\mathrm{a}}$ lição. Por disponibilizar de tempo dentro do calendário previsto pela instituição, foi possível realizar a Atividade III durante toda a aula (cf. apêndice 14). O objetivo dessa atividade era ter acesso às percepções das/os alunas/os quanto aos papéis sociais de homens e mulheres, à maneira como elas/es entendem a dinâmica dessas identidades na sociedade. Além disso, busco refletir sobre os possíveis motivos dessas práticas sociais.

$\mathrm{Na}$ seção seguinte, faço a descrição da atividade e a análise das interações entre as/os alunas/os.

\subsubsection{Atividade III: Vantagens e desvantagens de ser homem e mulher na sociedade}

Nesta aula, havia 10 alunas/os em sala, 5 meninas e 5 meninos. Fizemos dois grupos, um de cada gênero. Para iniciar a atividade, entreguei uma folha em branco para cada grupo. Para os meninos, pedi que pensassem nas vantagens e desvantagens de ser mulher na 
sociedade. As meninas deveriam fazer o mesmo com relação ao homem. Para tanto, solicitei que fizessem uma lista em francês das suas reflexões.

Durante a reflexão em grupos, elas/es iam tirando dúvidas de vocabulário. Após essa etapa da atividade, passamos para a reflexão com toda a turma. Começamos pelo grupo das meninas. À medida que citavam as vantagens e desvantagens encontradas, eu as anotava no quadro para que pudéssemos, posteriormente, refletir sobre cada uma delas. Fiz o mesmo com o grupo dos meninos. Nas tabelas a seguir, é possível encontrar a lista, traduzida, feita por ambos os grupos:

Tabela 3 - Vantagens e desvantagens de ser homem

\begin{tabular}{|l|l|}
\hline \multicolumn{1}{|c|}{ Vantagens } & \multicolumn{1}{c|}{ Desvantagens } \\
\hline Recebem salário maior & O estupro não é levado a sério \\
\hline Têm mais segurança & $\begin{array}{l}\text { Sofrem preconceito quando têm amigos } \\
\text { homossexuais }\end{array}$ \\
\hline $\begin{array}{l}\text { Têm maior liberdade para usarem a } \\
\text { roupa que querem }\end{array}$ & Maior pressão da família e da sociedade \\
\hline Têm mais influência e poder & Não podem ser vaidosos \\
\hline $\begin{array}{l}\text { Têm mais liberdade nas relações } \\
\text { amorosas }\end{array}$ & \\
\hline
\end{tabular}

Fonte: Atividade III

Tabela 4 - Vantagens e desvantagens de ser mulher

\begin{tabular}{|l|l|}
\hline \multicolumn{1}{|c|}{ Vantagens } & \multicolumn{1}{c|}{ Desvantagens } \\
\hline Lei Maria da Penha & Vivem em uma sociedade machista \\
\hline $\begin{array}{l}\text { Não têm obrigação de se apresentar para } \\
\text { o serviço militar }\end{array}$ & Menstruam \\
\hline Têm maior expectativa de vida & $\begin{array}{l}\text { São mais suscetiveis a serem assaltadas } e \\
\text { abusadas. }\end{array}$ \\
\hline Têm mais opções de roupa para uma festa & Devem ser bonitas \\
\hline Pagam menos para entrar em uma festa & \\
\hline
\end{tabular}

Fonte: Atividade III

Para a análise, selecionei alguns tópicos que se mostraram mais relevantes devido às interações e aos dados gerados a fim de responder às perguntas de pesquisa deste estudo.

Iniciamos o debate pelo grupo das meninas. Na reflexão sobre o primeiro tópico das vantagens de ser homem, as meninas afirmaram que eles recebiam mais que as mulheres. Cléo ressalta que é preciso ter em mente também a mulher da qual se fala:

\section{Interacão 7:}

Cléo : E também a gente precisa ver os diferentes tipos de mulheres porque tem uma pesquisa nos Estados Unidos que, por exemplo, a mulher branca recebe mais, ai depois vem a negra e depois vem a latina (...) mas também tem outra coisa, tipo homem negro recebe menos, homem latino...

Lauren : Tá, mas ai já é o racismo. 
Na interação 7, Cléo não comenta sobre a diferença de salário entre homem e mulher, mas avança trazendo a interseccionalidade entre as identidades de gênero e raça/etnia que será discutida mais adiante. Em seu posicionamento, ela demonstra ter consciência das intersecções das identidades sociais na vida de uma mulher, ou seja, na maneira como as identidades se interagem formando diferentes tipos de discriminações, como no próprio salário que uma mulher recebe. Quando se fala em gênero, a mulher tende a receber menos que o homem, porém ela é igualmente formada pelas identidades de raça e classe, por exemplo, que vão influenciar na maneira como ela é vista na sociedade.

Ao fazer a diferença não apenas entre homens e mulheres, mas também entre mulheres, Cléo parece perceber as relações de poder entre as identidades. Vale destacar que ela se baseia em uma pesquisa americana, indo além de visões do senso comum e trazendo uma reflexão sobre como os preconceitos e as discriminações estão presentes em outras sociedades. Isso demonstra seu engajamento e sua agência na busca por informações, bem como sua conscientização crítica da realidade. Nesse sentido, Freire (2011) aponta que tal consciência se dá quando o sujeito sai da ingenuidade e busca uma compreensão do lugar do ser humano no mundo.

A partir da colocação de Cléo, foi possível ressaltar como nossas múltiplas identidades de gênero, raça e classe social influenciam na maneira como somos vistas/os e, consequentemente, no lugar que ocupamos na sociedade. Isso envolve pensar nos acessos que temos aos espaços sociais de maior prestígio como educação, saúde, trabalho, lazer, dentre outros. A esse respeito, hooks (2010) enfatiza que as categorias sociais se interagem produzindo diferentes graus de discriminações e exclusões.

$\mathrm{Na}$ interação 7, discutimos, sobretudo, sobre a influência das categorias sociais nas discriminações contra as mulheres, mas acabamos não refletindo sobre o porquê de homens receberem mais. No momento da interação, outras perspectivas podem surgir, modificando o caminho anteriormente previsto. Contudo, teria sido interessante aqui questioná-las novamente a respeito do tópico trazido por elas.

Após essa interação, passamos para o tópico seguinte Têm mais segurança. O grupo das meninas afirmou que as mulheres são mais vulneráveis a serem abusadas devido a sua força física, ou seja, um aspecto biológico inerente aos sexos. Contudo, é interessante observar também de que maneira o lado social pode nos ajudar a entender essa realidade, ressaltando como mulheres são representadas na nossa sociedade. Se tomarmos como 
exemplo as novelas, os filmes e os programas de televisão, é possível perceber que mulheres tendem a ser representadas muitas vezes como objetos sexuais. Seus corpos são expostos cotidianamente, dando a impressão de que valem mais que suas próprias mentes. Essa representação, quando reforçada ao longo do tempo, influência na maneira como mulheres são vistas e nos papéis que lhes são atribuídos na sociedade, influenciando, inclusive, no salário que recebem. Tendo em vista que os gêneros são construídos socialmente, os papéis sociais de cada um correspondem a essa construção. Diante disso, grande parte da vulnerabilidade das mulheres advém, não apenas da sua força física, cuja influência não pode ser negada, mas, principalmente, da sua representação como objetos sexuais cuja função é satisfazer os desejos masculinos.

Mais adiante, passamos a discutir sobre as vantagens que os homens têm de poder usar a roupa que querem:

\section{Interacão 8:}

Lauren: Homens podem andar sem camisa.

Cléo: E... Também [falando baixinho] se as mulheres utilizam short, qualquer roupa que você usar, você vai ser julgada. Se está curta demais, é puta, se você usa longa demais...

Alunas/os: É crente.

Cléo: Você não tem uma roupa que não vão te julgar. E não importa a roupa que você usar, você vai ser assediada [inaudível].

Na interação 8, Lauren ressalta a liberdade do homem de poder andar sem camisa. Diferentemente do homem, Cléo aponta que mulheres são constantemente julgadas e assediadas, não importando a roupa que usam. A partir desse comentário, foi possível refletir que o assédio e o abuso não estão diretamente relacionados com a roupa que a mulher está usando, mas são reflexos da cultura. Em nossa sociedade, a mulher ainda tende a ser vista como objeto sexual, reforçando o que foi analisado no diálogo anterior.

Outro tópico abordado foi com relação à influência e ao poder do homem na sociedade:

\section{Interação 9:}

Professeure : Le pouvoir. Les homens, ils ont plus de pouvoir?

Élèves : Oui.

Professeure : Dans quel sens?

Lenor Estevão : Dans le gouvernement, dans la société...

Professeure : Oui, c'est ça ? Vous pensez que les hommes, ils ont plus de pouvoir que les femmes? 


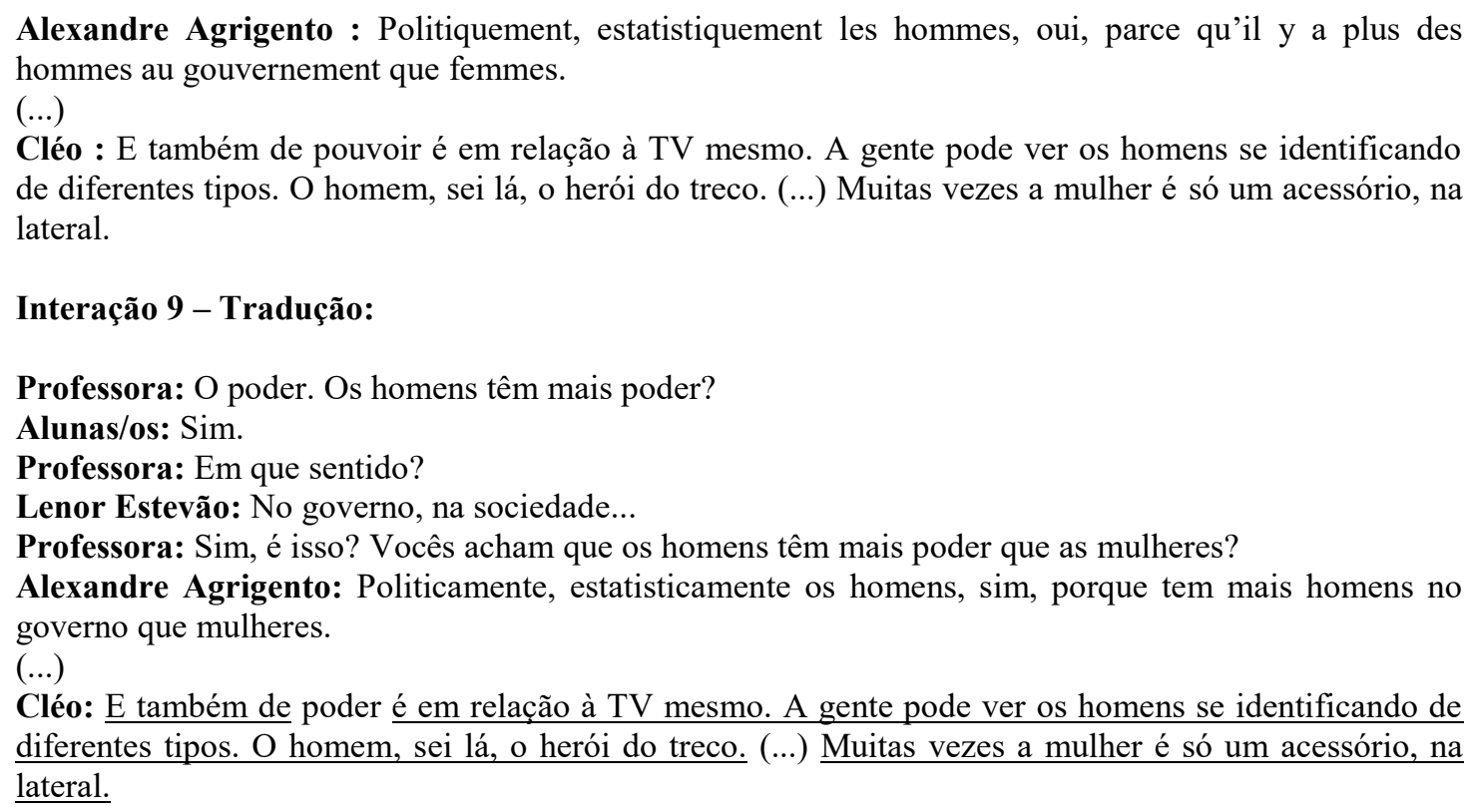

$\mathrm{Na}$ interação 9, busco saber em que sentido homens têm mais influência e poder que as mulheres. Cléo aponta o poder do homem na mídia. Ela ressalta que os papéis principais são representados por homens, já as mulheres aparecem em segundo plano. A partir dessa interação, foi possível refletir sobre os papéis das mulheres nos filmes em geral, como também nos contos de fada. Refletimos sobre a quantidade de mulheres como protagonistas e observei, juntamente com as/os alunas/os que, em geral, as mulheres têm o papel de romantizar a história ou ainda de trazer um cunho sexual. Já nos contos de fada, as meninas relataram que a princesa é idealizada, por ser branca, loira, magra e não ter problemas.

Com relação ao tópico Têm mais liberdade nas relações amorosas, as meninas relataram que homens são incentivados a se relacionarem com mulheres desde cedo, uma maneira de afirmar a sua masculinidade ao passo que meninas são incentivadas a serem reservadas. Na sociedade, essas práticas são naturalizadas, como se as diferenças decorressem dos sexos e não da construção social dos gêneros.

Após refletirmos sobre as desvantagens de ser homem, passamos a discutir sobre os tópicos trazidos pelos meninos. Ao considerarem a Lei Maria da Penha como vantagem, Cléo responde que "isso não é uma vantagem". Em seu posicionamento, a participante demonstra fazer uma reflexão crítica ao reconhecer que a lei advém do fato de as mulheres serem as maiores vítimas de violência doméstica, tornando-se, portanto, uma maneira de protegê-las por serem constantemente agredidas por seus companheiros no ambiente familiar.

Com relação ao segundo tópico Não têm obrigação de se apresentar para o serviço militar, Cléo ressalta que "mulheres não têm obrigação de se apresentar para o serviço militar 
por serem consideradas frágeis". Uma imagem que, aliás, é construída desde a infância a partir dos adjetivos a ela atribuídos, como será visto em maiores detalhes adiante. A fragilidade é, ainda hoje, uma caraterística associada ao gênero feminino, que acaba restringindo os espaços ocupados pela mulher na sociedade.

Não chegamos a discutir sobre a questão da maior expectativa de vida das mulheres, $o$ grupo dos meninos apenas apontou que isso se deveria ao fato de mulheres cuidarem mais da saúde que homens. Analisando socialmente, mulheres são ensinadas a serem mais cuidadosas, não apenas consigo, mas também com as/os outras/os. É possível que essa construção tenha levado mulheres a se preocuparem mais com o seu bem-estar.

No tópico seguinte Têm mais opções de roupa para uma festa, os meninos relataram a quantidade de roupas femininas para uma festa como vantagem, pois elas poderiam ser mais criativas. Em uma argumentação contra, as meninas destacaram a pressão da sociedade de a mulher estar sempre bonita, inclusive julgando aquelas que usam o mesmo vestido repetidamente. De fato, as mulheres são pressionadas a estarem sempre belas, estimulando-as a serem "criativas" para se adaptarem aos padrões de beleza excludentes e discriminatórios. Isso deixaria, portanto, de ser uma vantagem, pois se deve a uma pressão social contra a mulher. As/Os alunas/os trouxeram aqui uma perspectiva de classe social destacando a quantidade de roupas que mulheres teriam para se vestir em uma festa. Vale ressaltar que das/os 13 participantes, 10 estudam em escolas privadas sendo apenas 3 do convênio.

Discutimos mais detalhadamente o último tópico Pagam menos para entrar em uma festa. O grupo dos meninos destacou que mulheres têm a vantagem de pagar menos nas festas:

\section{Interação 10:}

Alexandre Agrigento : (...) les femmes payent moins à choses des fêtes.

Professeure : Ah, d'accord...

Alexandre Agrigento : Pour entrer.

Professeure : L'entré dans les fêtes.

Lenor Estevão : [risos]

Cléo : Ah mas, eu posso falar? Gente, quando, o motivo de estar pagando menos é pra encher o lugar...

Alexandre Agrigento : Eu sei, eu sei, mas é uma vantagem.

Cléo : Não é uma vantagem porque eles tão te tratando como produto, se você não paga pelo produto, você é o produto. Quando você enche o lugar...

Alexandre Agrigento : Mas os homens pagam mais...

Anna W : Por isso.

Cléo : Por isso, porque tem mulher lá dentro.

Lenor Estevão : Pra ter mais mulher lá dentro.

Cléo : A gente tá sendo tratado como objeto nesse caso, não é porque a gente paga menos, entendeu?

Alexandre Agrigento : Ah.

Johnson : Ah, mas vocês economizam [em tom jocoso]. 
Cléo : Mas a gente tipo, sendo cercada de homem [fazendo gestos de desgosto].

Professeure : Oui très bien, c'est bon de voir l'idée, 'pourquoi les femmes payent moins'?

Cléo : Não é em nosso benefício, é em benefício do homem.

Interação 10 - Tradução:

Alexandre Agrigento: (...) as mulheres pagam menos nas festas.

Professora: Ah, sei.

Alexandre Agrigento: Para entrar.

Professora: A entrada nas festas.

Lenor Estevão: [risos]

Cléo: Ah mas, eu posso falar? Gente, quando, o motivo de estar pagando menos é pra encher o lugar...

Alexandre Agrigento: Eu sei, eu sei, mas é uma vantagem.

Cléo: Não é uma vantagem porque eles tão te tratando como produto, se você não paga pelo produto, você é o produto. Quando você enche o lugar...

Alexandre Agrigento: Mas os homens pagam mais...

Anna W: Por isso.

Cléo: Por isso, porque tem mulher lá dentro.

Lenor Estevão: Pra ter mais mulher lá dentro.

Cléo: A gente tá sendo tratado como objeto nesse caso, não é porque a gente paga menos, entendeu?

Alexandre Agrigento: $\mathrm{Ah}$.

Johnson: Ah, mas vocês economizam [em tom jocoso].

Cléo: Mas a gente tipo, sendo cercada de homem [fazendo gestos de desgosto].

Professora: Sim, muito bem, é bom ver a ideia 'por que as mulheres pagam menos?'

Cléo: Não é em nosso benefício, é em benefício do homem.

$\mathrm{Na}$ interação 10, Alexandre Agrigento coloca o fato de mulheres pagarem menos para entrar em uma festa como vantagem. Cléo mais uma vez discorda e defende que o motivo de não pagar é para encher o lugar, trazendo a representação de mulheres como produtos. Interessante observar que ela usa a linguagem para desconstruir um discurso machista naturalmente aceito na sociedade e que tende a propagar a imagem dessa prática como uma vantagem quando na verdade não é. Como ressalta Silva (2014), da mesma forma que a linguagem é usada para construir discursos, ela também pode desconstruir, uma vez que as identidades não são fixas.

Alexandre Agrigento, porém, mantém o discurso machista que é reforçado por Johnson. Mesmo se posicionando em tom jocoso, seu discurso ratifica a naturalização dessa prática social. Segundo Butler (1999), esse status de verdade se deve a uma historicidade condensada que legitima discursos propagados e acumulados ao longo do tempo. Ao trazer a ideia de que essa prática na verdade existe em benefício do homem, Cléo favorece a problematização, mostrando que as/os alunas/os também contribuem para a construção e desconstrução das identidades.

Com base nas interações, percebe-se que as meninas trouxeram vantagens e desvantagens sociais de ser homem e a maneira como elas interferem na vida de homens e mulheres, revelando uma compreensão mais social das diferenças. Já os meninos parecem ter 
tido dificuldade em encontrar vantagens sociais de ser mulher. Das cinco apresentadas, é possível dizer que quatro delas não podem ser consideradas como vantagens, pois estão ligadas a situações de supremacia de poder masculina, não trazendo, de fato, impactos na vida de mulheres a ponto de colocá-las em um lugar privilegiado em relação aos homens.

A Lei $n^{\circ} 11.314$ de 7 de agosto de 2006 conhecida por Lei Maria da Penha é fruto de uma luta contra a violência doméstica da qual as mulheres são as maiores vítimas. Já o fato de mulheres terem mais opções de roupas que homens, de maneira geral, se deve a uma prática social que insiste em representar a mulher sempre bela, magra, alta e cheia de adereços que viriam a contribuir para esse padrão social. Na verdade, se observarmos melhor, isso se encaixa na desvantagem trazida pelo próprio grupo no tópico Devem ser bonitas. Ou seja, ao mesmo tempo em que veem como vantagem o fato de mulheres terem mais opções de roupa, eles destacam a pressão social de estarem sempre bonitas como desvantagem, não associando uma prática à outra.

O mesmo acontece no caso de mulheres não serem obrigadas a se apresentarem no serviço militar ou pagarem menos para entrar em uma festa. Ambas as práticas advêm da superioridade masculina que tende a ver a mulher como frágil ou como objeto sexual. Inclusive, é possível dizer que tais práticas ocorrem devido à sociedade machista em que vivemos - o primeiro tópico trazido pelos meninos no campo das desvantagens de ser mulher - onde o homem tem privilégios e maior valor social.

Baseando nas percepções do grupo das meninas, observa-se que, de maneira geral, elas demonstram ter uma visão mais crítica sobre o tema, trazendo pontos de vista que ressaltam as diferenças nas relações de poder entre homens e mulheres na sociedade. A aluna Cléo se destacou com seus posicionamentos ao trazer a interseccionalidade das categorias identitárias que demonstram reflexos da sua conscientização da realidade sobre as diferenças de gênero e intra-gênero. Ou seja, ela demonstra perceber a dinâmica das identidades sociais de gênero e raça/etnia, as relações de poder entre elas e como interagem produzindo diferentes graus de discriminação.

Suas reflexões contribuíram para que as/os alunas/os pudessem refletir sobre o porquê dos eventos e das práticas sociais. Elas/es puderam interagir e construir novos conhecimentos de maneira dialógica, abrindo espaço para possíveis (re)construções das identidades sociais de gênero dentro da perspectiva do LC na aula de francês como língua adicional. É interessante notar que as discussões deram espaço para as vozes das/os próprias/os alunas/os. Não era somente eu, a professora, problematizando as questões. As/Os próprias/os alunas/os fizeram isso e tiveram a oportunidade de ouvir as opiniões das/os colegas e suas conclusões. Essas 
reflexões nos mostram a importância de favorecer tais discussões nas aulas de línguas, para que as/os alunas/os possam perceber que nossas práticas sociais, bem como nossos pontos de vista sobre as pessoas e as situações são construídas historicamente dentro de um determinado tempo e espaço.

Ao final da aula, entreguei o questionário da Atividade III (cf. apêndice 3) para que pudessem expressar seus pontos de vista com relação ao tema discutido em sala. Nos questionários, as respostas foram muito positivas. Elas/es relataram ter se sentido "interessados", "confortáveis" e "felizes" ao expressar suas opiniões e ao ouvir as das/os colegas. Nesse sentido, José declara ter gostado de "conhecer o lado que as mulheres pensam". José é o aluno mais novo da turma - 14 anos - e se mostrou muito participativo e interessado nas discussões, prestando atenção nos pontos de vista das/os colegas e demonstrando refletir sobre eles. O participante Biel ressalta ter achado interessante discutir sobre o tema: "porque nos estimula a pensar em como há muito preconceito e como mudar seu pensamento sobre algumas coisas em nossa sociedade". Ou seja, refletir sobre temas sociais, pode nos ajudar a pensar sobre nossos próprios preconceitos, nos estereótipos, favorecendo um despertar para uma conscientização da realidade que pode propiciar mudanças e transformações na sociedade. A participante Lenor Estevão enfatiza que foi possível "ver que na realidade a maioria de diferenças entre os homens e as mulheres vem de 'normas' sociais e não naturais". Ela demonstra compreender que as práticas sociais associadas aos gêneros não se devem a fatores biológicos, mas sociais. Ela desnaturaliza e traz uma perspectiva social para as diferenças entre homens e mulheres na sociedade. Lenor Estevão demonstra ter uma percepção mais crítica da realidade, ela participa bastante das interações com opiniões e argumentos consistentes. Desde o início da pesquisa, ela demonstrou gostar do assunto e disse já ter lido livros sobre questões de gênero.

Esse dialogismo permite que as/os alunas/os tenham acesso a outros discursos, construindo o conhecimento de maneira interativa. A esse respeito, Alexandre Agrigento destaca que achou "muito bom discutir para chegar a uma opinião coletiva". Com efeito, a grande maioria relatou ter gostado da interação da turma e do interesse de todas/os em participar. As/Os alunas/os ressaltaram a importância de discutir um tema tão importante, incentivando a reflexão das diferentes formas de preconceito trazidas pela interseccionalidade e a mudança de pensamentos da sociedade.

Com relação à língua, Alexandre Agrigento e Biel disseram não encontrar dificuldades para se expressarem em francês. Em seus posicionamentos, Alexandre Agrigento busca, de fato, usar o francês. Já Biel, a meu ver o aluno mais responsáveis da sala, apesar de não 
demonstrar ter dificuldades para se expressar em francês, quase não se posiciona nas interações. Acredito que sua pouca participação possa advir da sua timidez, mas também por, possivelmente, não estar acostumado a expor seu ponto de vista ou mesmo a discutir a respeito desses temas em sala de aula. Em seu comentário, Lenor Estevão declara que "é bom ter este tipo de discussão em aula porque ajudar a melhorar a oralidade do francês". Já Lauren afirma ter tido um pouco de dificuldade em se expressar em francês por falta de prática. Apesar disso, ela é muito participativa. Em outra aula, ela afirmou gostar de discutir os temas de gênero em sala de aula, pois ainda há muita desigualdade entre homens e mulheres. Lara, José, Washington e Roberta destacaram ter tido dificuldades para encontrar as palavras adequadas. Para Cléo e Johnson a dificuldade encontrada foi para argumentar na língua. De fato, Roberta tende a se expressar bastante em português, acredito que por falta de prática para usar a língua francesa. Não importa a situação, ela tende a usar a língua materna não aproveitando, muitas vezes, as oportunidades da aula para desenvolver a língua-alvo. Já Lara e Washington buscam utilizar o francês nas interações. Lara é uma aluna da rede pública muito atenta às discussões, ela demonstra refletir bastante durante as interações. Washington, apesar de demonstrar gostar de discutir temas sociais em sala, muitas vezes, não se posiciona efetivamente, trazendo discursos jocosos para provocar o riso das/os colegas. Johnson também usa geralmente o francês para interagir. Ele demonstra ter maturidade para discutir sobre os temas, trazendo reflexões que constribuem para os debates. Já Cléo, apesar do imenso conhecimento do tema, tende a se expressar em português. No questionário, ela afirma que "alguns argumentos são difíceis de falar em francês". Imagino que, por ter tantas informações sobre o assunto, ela queira compartilhá-lhas ao máximo com as/os colegas e encontra, na língua portuguesa, maiores recursos para isso.

Nesse sentido, na primeira parte da aula, elas/es se expressavam prioritariamente em português, elas/es queriam falar, expor suas ideias de maneira mais detalhada e recorreram à língua materna. Contudo, ao longo da atividade, fui chamando atenção para o uso da língua francesa. Algumas/uns alunas/os conseguiram se expressar em francês em quase todas as interações. Como eu disponibilizava de tempo suficiente para realizar a atividade durante toda a aula e por se tratar de uma experiência nova tanto para mim quanto para eles, deixei-as/os falar e se expressar livremente. Busquei deixá-las/os à vontade para expor seus pontos de vista da maneira que achassem melhor. Procurei não interferir muito na interação, no fluxo de pensamento delas/es. Na verdade, percebi que aquele tipo de situação, em que elas/es podiam dialogar com as/os colegas de sala sobre um tema tão relevante na sociedade, bem como para suas próprias vidas, não era algo que acontecia geralmente. 
Ressalto aqui que, ver as/os alunas/os se expressando e se posicionando de maneira reflexiva e crítica nas aulas de francês, na tentativa de compreender a realidade na qual se encontram foi, para mim, fantástico e ao mesmo tempo emocionante. Não gostaria e nem poderia tirar isso delas/es e de mim, estávamos tentando transgredir as fronteiras sociais, estávamos vivenciando um momento único, pois o livro didático é, em geral, o próprio currículo dos cursos de línguas (TILIO, 2015b). Por essa razão, penso que não esperava encontrar tanta aceitação à proposta que iria fazer.

Acredito que uma das grandes vantagens de desenvolver um trabalho crítico em sala de aula esteja nos desdobramentos que ele pode ter na vida das/os alunas/os. Em menos de um mês após o início das aulas, a aluna Cléo comentou comigo que estava montando um grupo de debate com o grêmio estudantil da sua escola e que gostaria de abordar temas de gênero, raça e sexualidade. Ela disse que queria discutir com outras pessoas e compartilhar ideias sobre o assunto, pois, para ela, é muito importante que discussões como essas se propaguem e se espalhem. A reação da Cléo me deixou emocionada e orgulhosa, pois foi possível ver o alcance e os possíveis desdobramentos do trabalho com o LC na aula de línguas. Mesmo sabendo que ela já tinha esse engajamento antes das aulas, nossas discussões em sala foram mais um incentivo para que ela desenvolvesse ainda mais sua agência no mundo.

\subsubsection{Aula 17: 03 de maio de 2016}

Nesta aula desenvolvemos a Atividade IV que retrata as desigualdades entre homens e mulheres em diferentes contextos sociais. Havia 6 alunas/os presentes. Desenvolvi a atividade durante toda a aula. Esta atividade está disponível no site da TV5 Monde ${ }^{23}$. Trata-se de uma rede de televisão francófona que oferece programas, jogos, além de um espaço dedicado ao aprendizado da língua francesa. O objetivo era analisar a maneira como as/os participantes percebem os papéis sociais de homens e mulheres na sociedade refletindo sobre diversas práticas sociais.

No subtópico seguinte faço a descrição da referida atividade.

\subsubsection{Atividade IV: Desigualdades entre homens e mulheres}

\footnotetext{
${ }^{23}$ Disponível em: $<$ http://www.tv5monde.com/> . Acesso em: 22 mar. 2016, 15:18:16.
} 
O primeiro exercício da atividade corresponde à imagem a seguir:

\begin{tabular}{|c|c|c|c|c|c|}
\hline \multicolumn{6}{|l|}{$\begin{array}{l}\text { Masculin ou féminin ? } \\
\text { Activité } 1 \text { : }\end{array}$} \\
\hline & ${ }_{(h)}$ & $e_{(f)}$ & & $\sigma_{(\mathbf{h})}$ & $E_{(f)}$ \\
\hline gagnent beaucoup d'argent. & & & reçoivent un prix Nobel. & & \\
\hline dirigent une entreprise. & & & sont analphabètes. & & \\
\hline $\begin{array}{l}\text { s'occupent des tâches } \\
\text { ménagères. }\end{array}$ & & & sont violents. & & \\
\hline ont des accidents de voiture. & & & $\begin{array}{l}\text { ont de grandes } \\
\text { responsabilités politiques. }\end{array}$ & & \\
\hline
\end{tabular}

Fonte: TV5 Monde.

Aqui, as/os alunas/os deveriam ler os enunciados e dizer se, em geral, eles correspondiam aos homens ou às mulheres. A maioria das/os alunas/os concordou em suas repostas, ou seja, o lugar que cada gênero ocupa na sociedade estava, de certa forma, construído no imaginário coletivo. As respostas das/os alunas/os podem ser vistas na tabela a seguir:

Tabela 5 - Masculino ou feminino ${ }^{24}$

\begin{tabular}{|c|c|c|c|c|c|}
\hline & $\mathbf{H}$ & $\mathbf{M}$ & & $\mathbf{H}$ & $\mathbf{M}$ \\
\hline Ganham muito dinheiro & 6 & & Recebem um prêmio Nobel & 6 & \\
\hline Dirigem um empresa & 6 & & São analfabetos/as & 2 & 3 \\
\hline $\begin{array}{c}\text { Ocupam-se dos afazeres } \\
\text { domésticos }\end{array}$ & & 6 & São violentos/as & 6 & \\
\hline Têm acidentes de carro & 4 & 2 & $\begin{array}{c}\text { Têm grandes } \\
\text { responsabilidades políticas }\end{array}$ & 6 & \\
\hline
\end{tabular}

Fonte: Atividade IV.

Como pode ser visto na tabela 5, ao falar do prêmio Nobel, todas/os eram de acordo que há mais homens vencedores desse prêmio quando comparado à quantidade de mulheres. Lenor Estevão e Alexandre Agrigento destacam haver pouquíssimas mulheres nesse contexto. Devido ao posicionamento de ambas/os, pergunto por que isso acontece. Anna $\mathrm{W}$ disse que "no passado (...) os homens receberam mais educação". Apesar de as/os alunas/os terem voltado no tempo a fim de buscar possíveis respostas no passado, teria sido interessante questioná-las/os por que os homens foram mais à escola que as mulheres. O que levava os homens a estudarem mais? Isso implicaria rever a organização patriarcal da sociedade da

\footnotetext{
${ }^{24} \mathrm{Na}$ tabela 5, utilizo $\mathbf{H}$ para homem e $\mathbf{M}$ para mulher.
} 
época e que ainda persiste em muitos lugares nos dias de hoje. De fato, não estava nos meus planos buscar uma reflexão naquele momento da atividade, mas, tendo em vista o diálogo resultante desse tópico, teria sido interessante ter problematizado essas práticas naquele momento.

Isso nos mostra a complexidade de trabalhar na perspectiva crítica em sala de aula: não há como esgotar as discussões, nem sempre conseguimos prover todos os argumentos que gostaríamos ou que, em retrospectiva, julgamos ser necessários. Porém, é preciso lembrar que, no trabalho crítico em sala de aula, professoras/es e alunas/os estamos, todas/os, envolvidas/os em aprendizagem. Não há respostas prévias fechadas, maneiras préestabelecidas de responder e não há como cobrir todas as lacunas que as discussões e reflexões deixam. Essas lacunas fazem parte do movimento crítico e são essenciais para eles. Às/Aos professoras/es não cabe buscar preenchê-las como se fossem um problema.

Com relação ao tópico sobre o analfabetismo, pergunto por que há mais mulheres analfabetas que homens. Lenor Estevão se posiciona:

Interação 11:

Lenor Estevão : S’ils doivent choisir entre les femmes ou les hommes por aller à l'école, hã, les garçons ou les filles pour aller à l'école, ils ont choisi les...

Alexandre Agrigento : Les filles.

Lenor Estevão : Les garçons. Et maintenant ça s'est très dans les pays de l'Asie, dans l'Afrique, dans le... Meio Oriente?

Professeure : Le Moyen Orient.

Lenor Estevão : Le Moyen Orient, oui.

Interação 11 - Tradução:

Lenor Estevão: Se tivessem que escolher entre as mulheres ou os homens para ir à escola, hã, os meninos ou as meninas para ir à escola, eles escolhiam...

Alexandre Agrigento: As meninas.

Lenor Estevão: Os meninos. E agora isso acontece nos países da Ásia, na África, no... Oriente Médio?

Professora: Le Moyen Orient.

Lenor Estevão: Le Moyen Orient, sim.

Com base na interação 11, Lenor Estevão busca referências no passado para sustentar seu argumento. Tal prática vai ao encontro do que advoga Pennycook (2001) quando diz que é preciso compreender como as situações vieram a se encontrar da forma que estão e que, para isso, devemos buscar na história como a construção se deu. Ao dizer que as meninas vão preferencialmente à escola, Alexandre Agrigento parece buscar referências na sociedade atual, onde o ingresso de mulheres na escola cresceu significativamente nos últimos anos ultrapassando, atualmente, o contingente masculino (BRASIL, 2009). 
Após essa primeira parte da atividade, solicitei que formassem dois grupos de três pessoas para podermos trabalhar sobre as informações contidas nas tiras a seguir:

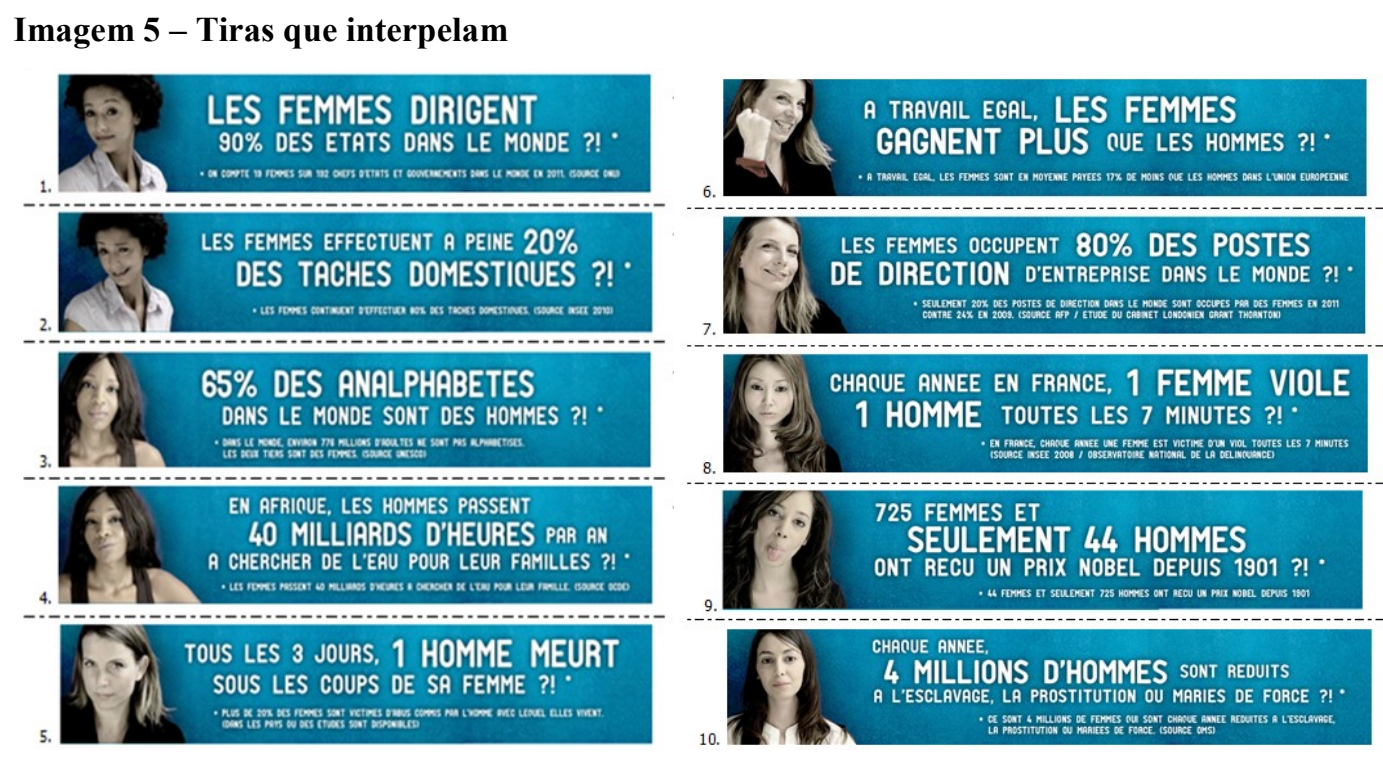

Fonte: TV5 Monde.

Distribuí para cada grupo cinco tiras e pedi que refletissem sobre os dados nelas contidos. As tiras contêm uma pergunta em destaque. Abaixo, em letras menores, há um enunciado. Ambos contêm dados estatísticos que foram invertidos para chamar a atenção da/o leitor/a e fazer refletir sobre eles. Ao ler as tiras, as/os alunas/os rapidamente contestaram os dados, dizendo que não eram verdadeiros. Chamei atenção para a sua estrutura, as letras maiores e menores. Ao observarem as informações, elas/es se deram conta de que os dados tinham sido invertidos e que a primeira frase aparecia em forma de pergunta a fim de buscar problematizar os dados. À medida que iam lendo as frases, eu ia trazendo outras informações para complementar. Com relação à primeira tira que questiona a pouca representatividade de mulheres na maioria dos postos de direção política, trouxe sites com informações de países chefiados por mulheres para que pudessem melhor visualizar essa prática.

Posteriormente, perguntei por que somente $10 \%$ de mulheres chefiavam os países. Anna W respondeu "porque é muito machista". No momento da aula, essa resposta me pareceu suficiente, mas, posteriormente, com outras leituras sobre o LC, pude perceber que teria sido interessante questionar o que ela entendia por machismo e por que ele tende a fixar os papéis exercidos pelos gêneros masculino e feminino. Minha preocupação era tamanha em trazer informações e dados que faltou questionar mais suas opiniões. 
De fato, durante a preparação das aulas, eu tinha uma grande ansiedade em procurar me informar o máximo possível, não apenas para me sentir mais preparada para perguntas que pudessem surgir em sala, mas também para que as/os alunas/os pudessem melhor visualizar as hierarquias, as estruturas sociais, bem como a organização da sociedade, refletindo sobre ela e, quem sabe, mudando suas concepções. Contudo, é importante lembrar que, muitas vezes, nós professores achamos que o nosso papel é mudar as opiniões das/os alunas/os e que isso é conscientizar. Mas hooks (2013) e Munanga (2005) afirmam que precisamos sensibilizar e isso significa deixar que o sujeito pense por si só. Assim, buscamos desestabilizar as sociabilidades (HOELZLE, 2016) cujos sentidos tendem a ser cristalizados e normalizados ao longo do tempo.

Percebi que poucas vezes durante a aula questionei sobre a origem dessas práticas sociais. Ao ouvir as aulas, pude perceber que meus questionamentos vieram, principalmente, quando houve divergência nas respostas das/os alunas/os. Isso me instigava a saber o porquê de seus posicionamentos. Contudo, nos tópicos nos quais todas/os estavam de acordo, não senti necessidade de questionar as práticas, como se fossem evidentes. Ou seja, inconscientemente, eu naturalizei algumas diferenças entre homens e mulheres, tendo em vista que elas passam, muitas vezes, despercebidas aos nossos olhos, pois estão enraizadas na cultura na qual fomos criados.

Isso nos mostra que o trabalho na perspectiva crítica não é previsível, não há certezas ou respostas prontas e acabadas. É um processo que envolve construir conhecimentos e problematizar práticas sociais juntamente com as/os alunas/os. Seguindo esse raciocínio, Lopes e Borges (2015) afirmam que um projeto de formação docente que prevê regras universais se torna impossível no sentido em que não é possível garantir ou prever comportamentos e resultados, pois a interação com a/o outra/o é imprevisível. Somos sujeitos formados por múltiplas identidade, cambiantes e transitórias (HALL, 2014; SILVA, 2014; MASTRELLA-DE-ANDRADE, 2013) e lidamos com outros sujeitos em diferentes contextos sociais.

No questionário da Atividade IV (cf. apêndice 4), as/os alunas/os destacaram se sentir confortáveis em discutir o tema por ser um assunto muito debatido atualmente. Lenor Estevão disse sentir-se "interessada por falar acerca destes assuntos, especialmente a ver estatísticas de mulheres e homens à volta do mundo". Para Roberta, conhecer novas situações faz "a gente refletir sobre a sociedade atual".

Com relação ao idioma, especificamente, Anna W afirma ter tido dificuldade em "argumentar sobre os temas em francês em decorrência da diferença de vocabulário". Em 
todo caso, a aluna busca, em seus posicionamentos, se expressar em francês. Ela demonstra interesse no tema e é muito participativa. Washington declara ser interessante discutir o tema para "aprender mais sobre a língua francesa e sobre assuntos que estão presentes em nosso dia a dia". Para Lenor Estevão, discutir sobre o tema na aula de língua foi "bom porque sinto o meu francês melhorar, especialmente em termos de vocabulário acerca destes assuntos". Além disso, ela afirma ter tido "mais facilidade para falar em francês do que nas outras aulas". Ou seja, dois meses após o início da pesquisa, ela já relata notar avanços nas suas capacidades linguístico-discursivas. Em seus comentários, elas/es afirmam sentir falta de vocabulário nas discussões, mas ao mesmo tempo, relatam aprender vocabulário com elas. Isso nos mostra como o LC favorece o uso da língua e, ao usá-la para suas necessidades pessoais, as/os alunas/os a aprendem cada vez mais.

Esses comentários demonstram que desenvolver um trabalho de LC na aula de línguas é, não apenas possível, mas desejável, pois as/os educandas/os desenvolvem suas capacidades de refletir sobre a realidade em que vivem (FREIRE, 2011) por meio da problematização de identidades sociais, possibilitando se apropriar da língua-alvo e usá-la para expressar suas ideias, opiniões e vivências. Consiste em uma formação cidadã que prepara as/os jovens para a vida social, capacitando-as/os a lidar com a diversidade e a agir na sociedade globalizada (MONTE MÓR, 2015; MENEZES DE SOUZA, 2011a).

\subsubsection{Aula 20: 12 de maio de 2016}

Nesta aula havia 10 alunas/os em sala. O aluno Manoca veio para a nossa turma transferido por questão de horário. Começamos a aula com o livro didático. Nele, havia um texto sobre o Filme L'odeur de la papaye verte do diretor de origem vietnamita Tran Anh Hùng. Havia também duas imagens retratando o filme:

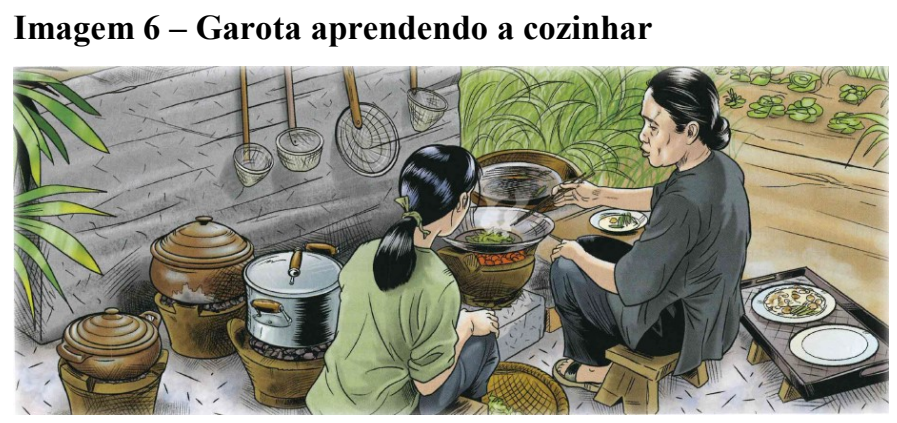

Fonte: Amis et compagnie 4, p. 32. 


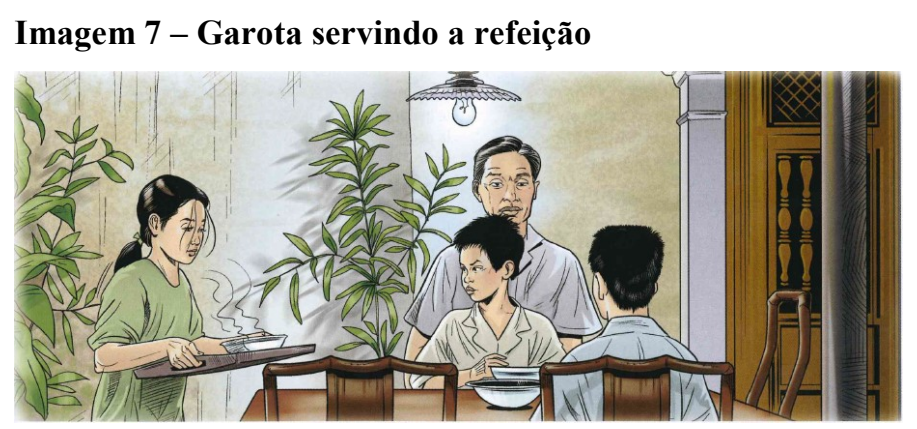

Fonte: Amis et compagnie 4, p. 33.

Buscando problematizar o livro didático, propus uma reflexão, com base nas imagens 6 e 7, sobre um dos possíveis papéis da mulher na sociedade vietnamita, a relação de hierarquia entre patroas/ões e empregadas, bem como o patriarcalismo que tende a colocar a mulher em uma posição social inferior ao homem. Discutimos sobre essa prática também em nossa sociedade, como isso acontece no nosso país.

A partir dessas imagens, comentamos sobre o preconceito de gênero e as maneiras pelas quais ele pode influenciar nossas vidas. A fim de melhor visualizar a construção social dos gêneros masculino e feminino, desenvolvi a Atividade $\mathrm{V}$.

\subsubsection{Atividade V: O que é o gênero?}

As concepções de gênero são construídas na e pela língua uma vez que as identidades são construídas nos discursos por meio da linguagem e das representações feitas a partir dos sistemas simbólicos (WOODWARD, 2014). Dessa forma, aprendemos a nos comportar e agir na sociedade de acordo com o gênero a nós designado a partir do sexo.

Nesta atividade, busco refletir como os gêneros são construídos na sociedade e suas implicações na vida pessoal e profissional de homens e mulheres. O objetivo era compreender como essa construção se deu historicamente, como isso acontece nos dias de hoje e quais as suas consequências em nossas vidas.

Para melhor compreensão da construção do gênero, passei um vídeo em francês intitulado $C^{\prime}$ est quoi le genre ? $^{25}$, no qual é feita a distinção entre o sexo e o gênero de uma pessoa e a maneira como este é construído na sociedade ao longo do tempo e do espaço. Aqui, refletimos novamente sobre a construção social do que é considerado masculino e feminino em um dado momento na sociedade. Além disso, discutimos sobre como meninos e meninas são educadas/os desde a infância com base em estereótipos que naturalizam nossa percepção

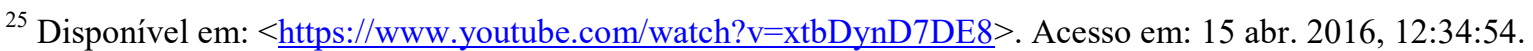


do que podem ou não fazer e como devem agir. O vídeo retrata as diferenças sutis, mas essencializadas, presentes na educação de ambas/os, desde os presentes de aniversário que cada um/a recebe até os adjetivos que não aparentemente apenas descrevem, mas, sobretudo, constroem cada um/a delas/es.

$\mathrm{O}$ vídeo traz a imagem das/os irmãs/os gêmeas/os Léa e Léo que comemoram o seu aniversário em família. Elas/es se divertem e brincam com os presentes que receberam. Uma imagem aparentemente normal. Porém, ao observar a cena sobre o prisma do gênero, é possível perceber os estereótipos presentes na educação de cada um/a. Ao discutirmos sobre os presentes de aniversário, vimos que há diferenças claras no que recebem: uma boneca, um livro e um aspirador de pó para Léa. Um monstro, uma nave espacial e uma bola de futebol para Léo, revelando as desigualdades na educação de meninas e meninos já na infância e que acabam por incentivar e restringir os papéis que vão exercer futuramente. Abaixo segue o diálogo dessa interação:

\section{Interação 12:}

Professeure : Qu'est-ce que ça veut dire ces cadeaux?

Washington : C'est la pression de la société.

Professeure : Quelle est l'importance de ces cadeaux dans la formation du genre ? Dans la manière dont cette personne va se voir?

Lauren : Parce que, hã...

Lara : Les cadeaux construit la personnalité de l'enfant. Il va crescer, il va...

Professeure : Quand il va grandir...

Lara : Sa personnalité c'est un reflèxe des cadeaux.

(...)

Professeure : Par exemple, on donne la poupée, vous comprenez une poupée?

Élèves : Oui.

Professeure : On donne une poupée à une fille, c'est très commun de donner une poupée à une fille.

Élèves : Oui.

Professeure : Pourquoi?

Manoca : Parce qu'elle va ser mère.

Professeure : Et on peut donner une poupée à un garçon?

Élèves : Oui.

Professeure : Est-ce que vous donneriez une poupée à un garçon ? (...)

José : Non.

Roberta : Un X Men.

Élèves : Un Max Steel.

Professeure : C'est commun de donner une poupée à un garçon ?

Élèves : Non.

Professeure : Pourquoi non?

Johnson : Poupée ? Qu'est-ce que c'est poupée?

Élèves : Uma boneca.

Washington : Parce que c'est l'influence...

Interação 12 - Tradução:

Professora: O que significa esses presentes?

Washington: É a pressão da sociedade. 
Professora: Qual a importância desses presentes na formação do gênero? Na maneira como essa pessoa vai se ver?

Lauren: Porque, hã...

Lara: Os presentes constroem a personalidade da criança. Ele vai crescer, ele vai...

Professora: Quando ele crescer...

Lara: Sua personalidade será um reflexo desses presentes.

(...)

Professora: Por exemplo, a gente dá uma poupée (boneca), vocês compreendem uma poupée?

Alunas/os: Sim.

Professora: A gente dá uma poupée para as meninas, é muito comum dar uma poupée para as meninas.

Alunas/os: Sim.

Professora: Por quê?

Manoca: Porque ela vai ser mãe.

Professora: E a gente pode dar uma poupée para um menino?

Alunas/os: Sim.

Professora: Vocês dariam uma poupée para um menino? (...)

José: Não.

Roberta: Um X Men.

Élèves: Um Max Steel.

Professora: É comum dar uma poupée para um menino?

Alunas/os: Não.

Professora: Por que não?

Johnson: Poupée? O que é poupée?

Alunas/os: Uma boneca.

Washington: Porque tem uma influência...

Passando para a análise dos presentes de aniversário, perguntei a importância deles para a formação do gênero, na maneira como a pessoa vai se ver. Washington ressalta a pressão da sociedade, provavelmente se referindo ao padrão de gênero criado e incentivado pela família. Lara frisa que a personalidade da criança é um reflexo dos presentes. Aqui, ela traz, na prática, a influência deles na formação da personalidade do sujeito, demonstrando entendê-lo como produto histórico, social e cultural. Assim sendo, os presentes, que podem ser considerados símbolos, bem como os adjetivos atribuídos a meninos e meninas, nos constroem como sujeitos. Isso nos mostra que nossas identidades são, de fato, formadas pelos discursos e pelas construções simbólicas (SILVA, 2014; WOODWARD, 2014).

Posteriormente, ressalto que é comum oferecer uma boneca de presente para as meninas e pergunto por que isso acontece. Manoca reage dizendo que é porque as meninas serão mães, reforçando o estereótipo da mulher que é educada para ser mãe, mesmo que, futuramente, ela não se veja como uma ou não tenha vontade de ter filhos. Contudo, como se pode observar, ninguém mencionou a possibilidade de oferecer uma boneca a um menino mesmo que ele possa vir a se tornar pai, retomando o argumento de Manoca no diálogo da interação 12. Da mesma forma, é comum meninos ganharem um carrinho de brinquedo, como retratado no vídeo, mas não as meninas. Contudo, em nossa sociedade, muito possivelmente, elas também vão dirigir quando atingirem a maioridade. Assim, 
à medida que crescemos, por meio dos brinquedos, jogos e brincadeiras, dos acessórios e das relações estabelecidas com os grupos de pares e com as pessoas adultas, vamos também aprendendo a distinguir atitudes e gestos tipicamente masculinos ou femininos e a fazer escolhas a partir de tal distinção, ou seja, o modo de pensar e de agir, considerados como correspondentes a cada gênero, nos é inculcado desde a infância (BRASIL, 2009, p. 48).

Dessa forma, as instituições sociais como a família, a escola, a igreja, dentre outros, vão nos ensinando os comportamentos adequados de acordo com o nosso gênero. Logo, elas "têm o poder de decidir e inscrever em nossos corpos as marcas e as normas que devem ser seguidas" (LOURO, 2008, p. 18). Isso nos mostra que os presentes oferecidos a meninos e meninas estão associados a práticas sociais tradicionais e que continuam a ser propagadas sem que se tenha uma reflexão a respeito. Mesmo com as inúmeras mudanças trazidas pela globalização e o capitalismo, transformando nossas vidas pessoais e profissionais e diversificando os espaços que ocupamos na sociedade, é possível encontrar práticas culturais que continuam a ser propagadas de geração em geração. Daí a importância de problematizálas para que as formações de meninos e meninas sejam construídas com base na equidade de gênero.

Continuamos a discussão sobre as diferenças na educação de meninos e meninas. Manoca destacou os adjetivos usados para qualificar e descrever os gêneros. No vídeo, os meninos tendem a ser qualificados desde a infância como fortes, briguentos, impulsivos, $\mathrm{X}$, esportivos e conquistadores. Já as meninas como doces, empáticas, reflexivas, calmas, organizadas e limpas. Tais adjetivos tendem a reforçar a imagem do homem como sendo naturalmente forte, sedutor e apto para o esporte, por exemplo. Por outro lado, as meninas são qualificadas e educadas de maneira a propagar a imagem da mulher como sendo naturalmente mais tranquila, carinhosa, organizada e limpa. Tais adjetivos constroem nossas identidades, ou seja, a forma como nos vemos e somos vistas/os, reforçando os estereótipos. Abaixo, é possível encontra o diálogo correspondente:

\section{Interação 13:}

Professeure : Quelle est l'importance de ces adjectifs dans la construction [de gênero] d'un garçon et d'une fille?

José : C'est que la société, elle insère ces adjectifs dans ces filles, dans les hommes et les filles... como é que diz crescem?

Professeure : Grandissent.

José : Ils grandissent avec ces adjectifs. 
Professeure : Exactement, donc les filles et les garçons, ils grandissent avec ces adjectifs. Ils créent une identité à partir de ces adjectifs. (...)

(...)

Professeure : (...) Donc on voit que les cadeaux, les adjectifs, ils forment l'identité de la personne, oui ? Vous êtes d'accord?

Élèves : Oui.

Alexandre Agrigento : On peut dire aussi, ils encouragent.

Interação 13 - Tradução:

Professora: Qual a importância desses adjetivos na construção [de gênero] de um menino e de uma menina?

José: É que a sociedade, ela insere esses adjetivos nas meninas, nos homens, e as meninas... como é que diz crescem?

Professora: Grandissent.

José: Grandissent com esses adjetivos.

Professora: Exatamente, então as meninas e os meninos crescem com esses adjetivos. Eles criam uma identidade a partir desses adjetivos. (...)

(...)

Professora (...) então, a gente percebe que os presentes, os adjetivos formam a identidade da pessoa, sim? Vocês concordam?

Alunas/os: $\mathrm{Sim}$.

Alexandre Agrigento: A gente pode dizer também, eles incentivam.

A fim de melhor compreender suas percepções sobre o gênero, pergunto qual a importância desses adjetivos na vida de meninos e meninas. José responde que a sociedade lança mão de tais adjetivos para nos descrever e que crescemos com eles. As palavras de José revelam sua percepção de que meninos e meninas constroem suas identidades a partir desses adjetivos. Em outras palavras, os adjetivos utilizados na educação das crianças vão construindo os gêneros, a maneira como vão agir nas diferentes práticas sociais. Sendo assim, somos educadas/os para agir de acordo com o que a sociedade espera de nós. Isso se deve ao caráter performativo das identidades cuja eficácia se encontra na sua constante repetição (BUTLER, 1999). Dessa maneira, ao proferir discursos sobre alguém, não estamos apenas descrevendo uma pessoa, mas agindo sobre ela, os adjetivos se tornam, assim, atos linguísticos que contribuem para reforçar suas identidades (SILVA, 2014).

Ao perguntar se concordam que tais presentes, bem como os adjetivos atribuídos a ambos os gêneros constroem suas identidades, elas/es respondem que sim. $\mathrm{Na}$ sua fala, Alexandre Agrigento traz uma percepção crítica da influência desses adjetivos. Ou seja, eles não definem as identidades de uma pessoa de maneira fixa, mas incentivam na sua construção. Diante disso, as/os alunas/os parecem perceber que a sociedade direciona as atitudes de meninas e meninos atribuindo a elas/es qualidades e comportamentos diferentes que vão influenciar nas escolhas que farão futuramente em suas vidas pessoais e profissionais, bem como nos lugares que ocuparão na sociedade. À primeira vista, essas escolhas parecem 
ser individuais, frutos de seus desejos e aspirações. Contudo, elas provêm de uma educação social mais ampla e de discursos propagados e reforçados ao longo de suas vidas, ditando o que é preferencialmente para homens e mulheres. Muitas de suas escolhas profissionais não resultam de razões biológicas ou inatas, mas sociais, do que podem ou não fazer, ou melhor, do que podem ou não ser.

Isso pode ser visto no vídeo ao retratar as desigualdades profissionais entre homens e mulheres. É possível observar que mulheres trabalham, sobretudo, em cargos ligados à escuta, à organização, ao cuidado e à educação. Já os homens se voltam para profissões técnicas e científicas que são mais valorizadas e melhor remuneradas, chegando a ganhar mais para realizarem o mesmo serviço. Com efeito, os homens ainda se encontram em cargos de maior responsabilidade e poder devido a um valor a ele atribuído desde os primórdios da sociedade patriarcal.

Após visualizarem novamente essa parte do vídeo, perguntei quais eram as desigualdades no trabalho:

\section{Interação 14:}

Professeure : Quelles sont les inégalités au travail ?

Roberta : Les homens gagnent plus qu'elles.

José : Não sei se está certo: les hommes occupent les [inaudível] avec plus de pouvoir.

Professeure : Ils occupent des postes qui ont plus de pouvoir.

Roberta : Elles s'occupent de l'organisation, de l'école et de...

Manoca : Je pense que aujourd'hui, c'est plus différent.

Roberta : Claro que não.

Lauren : Continua do mesmo jeito.

Professeure : Il y a encore beaucoup de choses comme ça ?

Élèves : Oui.

Professeure : Washington, vient là. [mostrando uma cadeira próxima de mim]. Est-ce que cette situation, elle existe encore?

Élèves : Oui.

Professeure : Et pourquoi les hommes occupent majoritairement les postes de direction et de responsabilité.

Élèves : [não respondem]

Professeure : Pourquoi, quelle est la logique? Ils sont plus intelligents?

Lauren : Non.

José : Je pense que c'est, pour les hommes, il y a beaucoup de opportnuités de que les femmes.

Manoca : C'est vrai.

\section{Interação 14 - Tradução:}

Professora: Quais são as desigualdades no trabalho?

Roberta: Os homens ganham mais que elas.

José: Não sei se está certo: os homens ocupam os [inaudível] com mais poder.

Professora: Eles ocupam os cargos de maior poder.

Roberta: Elas se ocupam da organização, da escola e de...

Manoca: Eu acho que hoje é diferente. 


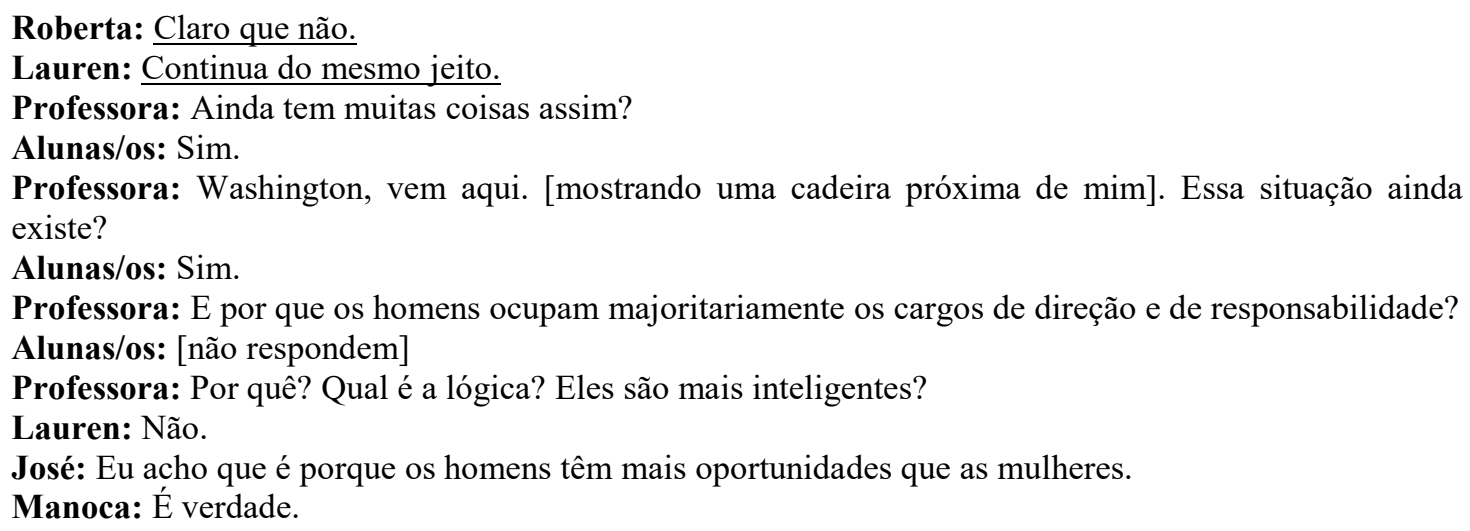

$\mathrm{Na}$ interação 14, destaco a afirmação de Manoca alegando que hoje em dia os homens não tendem mais a ocupar espaços de maior prestígio no trabalho. Ou seja, ele parece não perceber as relações assimétricas de gênero que persistem em colocar homens em cargos de chefia ou direção. Contudo, Roberta e Lauren se posicionam contra esse discurso, problematizando essa prática. Assim, diante da afirmação de José de que os homens têm mais oportunidades que as mulheres, trazendo uma percepção mais crítica da realidade, Manoca parece se dar conta de que, apesar de algumas mudanças terem acontecido no cenário profissional, devido ao acesso de mulheres aos estudos e ao trabalho, os homens ainda têm maiores oportunidades e são incentivados a ocuparem os cargos de maior importância.

$\mathrm{Na}$ interação 14, foi possível questionar a presença majoritária de homens nos cargos de poder. Por meio do posicionamento de Manoca ao dizer que "hoje é diferente", as/os alunas/os tiveram a oportunidade de interagir e (re)construir os sentidos e entendimentos dessa prática.

$\mathrm{O}$ vídeo aborda ainda as desigualdades encontradas no espaço familiar no que tange aos afazeres domésticos. Foi possível observar que as mulheres ainda tendem a passar mais tempo que os homens realizando os trabalhos domésticos, ocupando-se com a limpeza, as compras ou ainda cuidando dos filhos.

Nas interações, desenvolvidas a respeito do vídeo, algumas/uns alunas/os demonstraram ter consciência social das desigualdades e diferenças entre homens e mulheres, bem como da dinâmica dessas identidades na sociedade, indo além de estereótipos do senso comum que tendem a naturalizar as diferenças. Isso nos mostra que os movimentos sociais e os discursos de resistência também estão promovendo reflexões fora da sala de aula, auxiliando na construção dos discursos das/os alunas/os que colaboram para o desenvolvimento do trabalho com o letramento crítico em sala de aula. 
No final da interação, salientei que o objetivo era que elas/es pudessem ver a origem dessas diferenças, que elas não são biológicas, mas histórica, cultural e socialmente construídas e que as desigualdades sociais entre homens e mulheres são produtos da educação, da cultura e das tradições, sendo, portanto, frutos de práticas históricas de cada sociedade. Devido ao tempo, não foi possível entregar o questionário da atividade. Porém, as/os alunas/os disseram ter gostado de ter visto as diferenças nos presentes de aniversário, bem como nos adjetivos que influenciam na vida de meninas e meninos.

Nessa atividade, percebi a relevância de um ensino baseado no LC para favorecer a reflexão e a problematização das identidades sociais em sala de aula. O vídeo foi uma possibilidade encontrada para discutir essas questões. Contudo, desenvolver esse ensino demanda da/o professor/a não apenas conhecimento, mas também atenção e sensibilidade em relação aos diversos posicionamentos das/os alunas/os que acontecem, muitas vezes, ao mesmo tempo, a fim de não desconsiderá-los no momento em que surgem nas discussões.

Ao analisar as aulas, percebo que eu buscava um fechamento, uma conclusão, como se, ao final da atividade, as/os alunas/os tivessem que compreender o porquê das práticas sociais. Contudo, é importante ter em mente de que não há verdades absolutas. Nas aulas, as interações são múltiplas e, muitas vezes, não nos damos conta dos inúmeros eventos que elas trazem. Daí a impossibilidade de prever ou garantir resultados.

\subsubsection{Aula 21: 17 de maio de 2016}

Somos seres de múltiplas identidades que influenciam na maneira como nos vemos inseridas/os no mundo social (WOODWARD, 2014; HALL, 2014; LOURO, 2003; MASTRELLA-DE-ANDRADE, 2013), bem como nos acessos que temos às diferentes estruturas sociais como saúde, educação, moradia, lazer, dentre outros. Ou seja, nossas identidades de gênero, raça/etnia e classe social, por exemplo, interferem diretamente nas nossas condições e perspectivas de vida (HOOKS, 2013). Nesse sentido, Norton (2000), assevera que nossas identidades têm a ver com a maneira como nos vemos posicionadas/os no mundo ao longo do tempo e do espaço, bem como com as perspectivas que temos para o futuro. Em outras palavras, as identidades envolvem os acessos e os embargos que temos na vida social.

A esse respeito, Oliveira (2006, p. 36) ressalta que "as 'regras do gênero' são instrumentos de classificação social, hierarquização, dominação e poder" que se nutrem dos demais sistemas discriminatórios como classe, raça e etnia. Daí a importância de analisar as 
identidades de gênero juntamente com as de raça/etnia, uma vez que estas estão, geralmente, correlacionadas com as de classe social. A interseccionalidade coloca em evidência as diversas identidades sociais, correlacionando-as com outros eixos identitários: classe social, gênero, sexualidade, idade etc., ou seja, elas estão sempre inter-relacionadas, não são dissociadas (HOOKS, 2015, 2013).

Em seu texto Mulheres negras: moldando a teoria feminista, hooks (2015, p. 194) chama atenção para o fato de o feminismo ter começado por parte de um seleto grupo de mulheres brancas de classe-média e alta, casadas, universitárias com tempo ocioso e que queriam "mais" que seus maridos e família, queriam uma profissão. Porém, a autora questiona que esse grupo de mulheres não representava todas as mulheres, suas angústias e necessidades, pois não tinham consciência das demais opressões que mulheres negras e pobres sofriam. Ou seja, elas não se davam conta de como as categorias sociais se interseccionam produzindo diferentes tipos de opressões, exclusões e violências (HOOKS, 2015).

Dessa forma, não é possível falar em mulher como sujeito único e universal. É essencial discutir o gênero associado com questões de classe e raça a fim de se levar em conta características contextuais e contingentes das mulheres, pois, como destaca hooks (2013, p. 75), a raça e a classe social são fatores que "moldam a identidade feminina", trazendo consequências específicas em suas vidas.

Neste trabalho, decidi trazer o gênero com o recorte da raça/etnia para que fosse possível verificar como essas categorias sociais se combinam e se entrecruzam, atingindo as mulheres de modos diferentes. Por conta disso, desenvolvi a Atividade VI na intenção de analisar as representações das/os alunas/os a respeito de mulheres brancas e negras na sociedade, além de discutir a supremacia branca e sua influência na construção de estereótipos. Nesta aula, havia 10 alunas/os em sala.

\subsubsection{Atividade VI: Representações de mulheres brancas e negras}

Nessa atividade, projetei 15 imagens de mulheres brancas e negras de sucesso e escrevi suas respectivas profissões em uma lista separada no quadro (cf. apêndice 15). Pedi que, individualmente, observassem as imagens e as correlacionassem com as profissões listadas no quadro. O objetivo era ter suas percepções sobre as profissões das mulheres brancas e negras. Contudo, acredito que teria sido interessante deixá-las/os analisar as imagens das mulheres e imaginar livremente suas possíveis atividades, ou ainda trazer outras 
além das correspondentes às mulheres projetadas. Assim, teria sido possível verificar as profissões elencadas para cada uma delas. Como eu trouxe suas profissões previamente, não foi possível ter acesso às imagens que elas/es tinham em mente de possíveis profissões de mulheres brancas e negras e analisar como a raça poderia influenciar em suas escolhas.

No entanto, ao longo da discussão, instiguei-as/os a refletir sobre as imagens. Ao mostrar a foto da jornalista Maria Júlia Coutinho, elas/es reagiram:

\section{Interação 15:}

Professeure: Et là ?

Élèves : Journaliste.

Professeure : Vous la connaissez?

Élèves : Maria Júlia Coutinho.

Lauren : Elle a subi racisme de grand part de Brasil.

Professeure : Pourquoi?

Lauren : Por que ela é negra.

Professeure : Mais qu'est-ce qu'ils ont dit ?

Lauren : Não, eles falaram que tipo, eu nem vi os comentários porque eu achei ridículo. Eles falaram assim que atacaram ela pelo fato dela ser negra.

Johnson : É tipo nas páginas da internet, xingando ela, fazendo comentários racistas, assim.

Washington : Mas por quê?

Lauren : Porque ela é negra.

Washington : Mas ela fez alguma coisa?

Lauren : Não cara, porque ela chegou lá e apresentou, e pronto. (...)

Professeure : Pourquoi vous pensez que les gens ont eu cette réaction quand ils l'ont vue au Jornal Nacional?

Lauren : Porque eles nunca veem... No ambiente de trabalho...

Professeure : Qui sont les journalistes, en général ? Comment ils sont?

Lauren : Brancos.

Professeure : Et quand ils voient un noir, ou une femme noire, c'est quelque chose de différent, oui ? Pourquoi c'est différent?

Anna W : Parce que...

Lauren : Pra mim não é diferente.

(...)

Professeure : Mais je voudrais savoir, pourquoi nous avons ce regard par rapport à une femme noire? Parce que si Maju, elle était blanche, elle aurait subi des préjugés ? (...) Pourquoi vous pensez que la société a ce regard différent envers les noirs?

Élèves : [eles não respondem]

Professeure : Aucune idée ? Quel est le problème d'avoir une femme noire au Jornal Nacional ?

Manoca : Tem que falar em francês?

Professeure : Non, tu peux dire.

Manoca : Porque sempre as pessoas negras, elas sempre estiveram nos cargos inferiores, elas nunca foram, estiveram, por exemplo, na televisão. Elas nunca tiveram cargos na qual eram expostas para todo mundo ver, então eu acho que as pessoas não...

Lauren : É as pessoas hoje em dia, elas ainda relacionam o negro com...

Manoca : Com inferioridade.

Professeure : Si on va voir par exemple les films, les feuilletons, quelle est la place des noirs ? Où sont les noirs?

Washington : Le ménage.

José : As favelas, essas coisas.

(...)

Professeure : Quand on pense à un médecin. Il est comment ? Quelle est la première image qui vient à votre tête quand je dis 'médecin'?

Wasghington : Il est blanc. 
Lara : Blanc.

José : Il est homme.

Professeure : Classe sociale ?

Élèves : Riche.

(...)

Professeure : Chanteuse d'opéra?

Élèves : Blanche.

Anna W : Gordinha.

Professeure : Chateuse de reggae ?

Lauren : Bob Marley, dread.

Johnson : Noire.

Professeure : Femme de ménage?

Élèves : Noire.

\section{Interação 15 - Tradução:}

Professora: E lá?

Alunas/os: Jornalista.

Professora: Vocês a conhecem?

Alunas/os: Maria Júlia Coutinho.

Lauren: Ela sofreu racismo por grande parte do Brasil.

Professora: Por quê?

Lauren: Por que ela é negra.

Professora: Mas o que disseram?

Lauren: Não, eles falaram que tipo, eu nem vi os comentários porque eu achei ridículo. Eles falaram assim que atacaram ela pelo fato dela ser negra.

Johnson: É tipo nas páginas da internet, xingando ela, fazendo comentários racistas, assim.

Washington: Mas por quê? Ela fez alguma coisa?

Lauren: Não cara, porque ela chegou lá e apresentou, e pronto. (...)

Professora: Por que vocês acham que as pessoas tiveram essa reação ao vê-la no Jornal Nacional?

Lauren: Porque eles nunca veem... No ambiente de trabalho...

Professora: Quem são os jornalistas em geral? Como eles são?

Lauren: Brancos.

Professora: E quando eles veem um negro, ou uma mulher negra, é diferente, sim? Por que é diferente?

Anna W: Porque...

Lauren: Pra mim não é diferente.

(...)

Professora: Mas eu queria saber, por que nós temos esse olhar para a mulher negra? Porque, se a Maju fosse branca, ela teria sofrido preconceito? (...) Por que vocês acham que a sociedade tem esse olhar diante dos negros?

Alunas/os: [eles não respondem]

Professora: Nenhuma ideia? Qual é o problema de ter uma mulher negra no Jornal Nacional?

Manoca: Tem que falar em francês?

Professora: Não, você pode dizer.

Manoca: Porque sempre as pessoas negras, elas sempre estiveram nos cargos inferiores, elas nunca foram, estiveram, por exemplo, na televisão. Elas nunca tiveram cargos na qual eram expostas para todo mundo ver, então eu acho que as pessoas não...

Lauren: É as pessoas hoje em dia, elas ainda relacionam o negro com...

Manoca: Com inferioridade.

Professora: Se a gente for ver, por exemplo, os filmes, as novelas, qual é o lugar do negro? Onde ele está?

Washington: Nos trabalhos domésticos.

José: As favelas, essas coisas.

(...)

Professora: Quando a gente pensa em um médico? Como ele é? Qual a primeira imagem que vem à mente quando eu digo 'médico'?

Washington: Ele é branco.

Lara: Branco.

José: Ele é homem.

Professora: Classe social? 


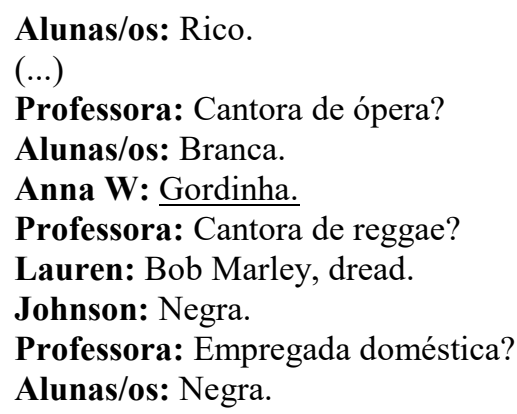

Diante dos posicionamentos de Lauren e Johnson ao lembrarem o racismo sofrido pela jornalista nas redes sociais, busco questioná-las/os do porquê dessa discriminação. Ao dizer que o motivo seria a cor da pele, Lauren traz o estereótipo da/o negra/o que sofre racismo, apenas por ser negra/o, mas não comenta a origem e o porquê desse preconceito.

Mais adiante, questiono sobre o olhar diferente em direção à/ao negra/o. Lauren diz não ver diferença, possivelmente por não ter consciência dela. Isso nos remete ao que hooks (2010) chama de supremacia branca. Segundo a autora, "a supremacia branca subjaz o pressuposto de que os negros são intelectualmente inferiores"26 às/aos brancas/os (HOOKS, 2010, p. 98). Contudo, a autora ressalta que isso não significa necessariamente que as/os brancas/os desejam colocar as/os negras/os em uma posição de discriminação racista, pois, para ela, os preconceitos são inconscientes e estão baseados na supremacia branca.

A mulher negra tende a ser representada pelas mídias de maneira estereotipada baseada em imagens que decorrem do período colonial, seja pela "empregada doméstica" ou pela "mulata" sexualizada (CARNEIRO, 2004, p. 318). A autora ressalta que as imagens de gênero advindas dessas representações contribuem no imaginário social para a desvalorização social, estética e cultural da mulher negra e na supervalorização da mulher branca.

Hooks (2010) argumenta que a desvalorização sexual da mulher negra, que começou na escravidão e persiste ainda hoje, alimenta as noções racistas e sexistas de que as mulheres negras não são capazes de pensar racionalmente. Assim, o estereótipo da mulher negra não pensante é reforçado cotidianamente, contribuindo para limitar e naturalizar os espaços ocupados por ela na sociedade brasileira, além de negligenciar o histórico deixado pela escravidão no Brasil, uma vez que a abolição não previa inserção das/os negras/os na vida social, política e econômica do país.

Continuo indagando a respeito do olhar da sociedade sobre a/o negra/o. As/Os alunas/os parecem procurar respostas, mas não se posicionam. Insisto na pergunta e Manoca

\footnotetext{
${ }^{26}$ Tradução de: White supremacy underlies the assumption that black folks are intellectually inferior or not the equals of their white counterparts.
} 
traz uma percepção crítica da realidade ao dizer que "as pessoas negras, elas sempre estiveram nos cargos inferiores". Diante disso, Lauren parece se dar conta desse fato e concorda com Manoca dizendo que, hoje em dia, as pessoas "ainda relacionam o negro com..." ao que Manoca complementa, afirmando "com inferioridade".

Durante a interação, continuo questionando e buscando exemplos das representações da/o negra/o que reforçam sua inferioridade. Washington e José trazem exemplos claros dessa representação, ratificando a construção da supremacia branca. Da mesma forma, ao questionar sobre as imagens que vêm à mente ao mencionar alguns profissionais, é possível perceber que as identidades sociais de gênero, classe e raça/etnia, no que tange à profissão, estão construídas no imaginário social das/os alunas/os e correspondem, sobretudo, às imagens propagadas pela mídia em geral. Contudo, a mídia também pode contribuir para a desnaturalização das identidades como é o próprio exemplo da jornalista Maria Júlia Coutinho. Ou seja, mesmo em menor grau, a mídia também tem contribuído com diferentes representações de gênero, raça/etnia e sexualidade em espaços mais privilegiados.

Em outro momento da aula, questionei se, caso tivesse trazido outra imagem da jornalista Maria Júlia Coutinho em uma época em que ela não era nacionalmente conhecida, elas/es diriam que ela era jornalista. Nesse instante, Lara interrompeu o silêncio da sala respondendo, de maneira assertiva, que não. $\mathrm{Na}$ verdade, ela rompeu o seu próprio silêncio ao deixar sua voz ser ouvida, pois, poucas vezes, ela participou das interações ativamente. $\mathrm{Na}$ maioria das vezes, ela ouvia as/os as opiniões das/os colegas e parecia refletir sobre elas, mas não costumava se posicionar naquele espaço.

Com base na interação 15, percebe-se que negras/os ainda tendem a ser representadas/os com base em estereótipos advindos do período colonial. O diálogo nos mostra ainda que, mesmo transgredindo as barreiras impostas pelo gênero e pela classe social, a mulher negra ainda encontra dificuldade para romper as fronteiras da raça, sendo frequentemente vítima de preconceitos e discriminações raciais.

Tendo em vista o poder dos meios de comunicação para a construção das identidades sociais, Carneiro (2004, p. 318) assevera que eles "não apenas repassam as representações sociais sedimentadas no imaginário social, mas também se instituem como agentes que operam, constroem e reconstroem no interior da sua lógica de produção os sistemas de representação", ocupando "posição central na cristalização de imagens e sentidos sobre a mulher negra".

Não há dúvidas de que a mulher negra precisa ser representada positivamente nos meios de comunicação a fim de possibilitar maior visibilidade nos espaços sociais. Mesmo 
com as conquistas das lutas das mulheres negras, bem como do Movimento Negro por uma maior e melhor representatividade, ainda falta muito a ser feito. A fim de mudar esse quadro, Carneiro (2004) advoga por uma representação da mulher negra em diferentes funções, exercendo suas habilidades mesmo em condições econômicas adversas.

Mais adiante, quando perguntei por que as/os negras/os tendem a se encontrar em espaços menos valorizados, as/os alunas/os ressaltam a escravidão. Johnson afirma que colonizadores trouxeram escravas/os africanas/os para o Brasil. Nesse momento, ressaltei que não se tratavam de escravas/os, mas de pessoas que foram escravizadas. A partir desse posicionamento, perguntei o que aconteceu com as/os ex-escravas/os após a abolição da escravatura no Brasil:

\section{Interação 16:}

Anna W: Eles ficaram abolidos da escravidão, mas ainda tinha...

Roberta: Tinha uma exclusão social.

Anna W: Eles ficaram sem suporte. Deixou de escravizar. Mas aí teve muitos que continuaram...

Manoca: Trabalhavam assalariados.

Anna W: Se eles saíssem do negócio...

Roberta: Eles não teriam condições de vida...

Anna W: Então eles preferiam ficar lá [na casa grande], porque eles não iam ter lugar pra dormir.

$\mathrm{Na}$ interação 16, é possível perceber que Anna W e Roberta demonstram perceber as consequências da escravidão na vida das pessoas negras no país, ressaltando a falta de oportunidades deixada às/ aos negras/os que se viram obrigadas/os a continuar na casa grande servindo as/os senhoras/es e sofrendo as mesmas discriminações e violências do período da escravidão. Apesar de não ser mais escrava, essa parte da população brasileira, que era majoritariamente superior à população branca após a abolição (CRUZ; RODRIGUES; BARBOSA, 2011), não pôde ver mudanças em suas condições de vida. A partir desse diálogo, ressaltei que as grandes desigualdades sociais e as diferenças de acessos à educação, à saúde e ao lazer entre brancas/os e negras/os no país são apenas algumas consequências da escravidão.

Após essa reflexão, busquei discutir com elas/es sobre o caso de uma professora negra que conta o que aconteceu no dia em que foi assinar o contrato para assumir o cargo de professora universitária. A professora narra que, ao se identificar com a documentação em mãos, não acreditaram que ela estaria ali por ser concursada e não para pedir emprego: 
Quando eu entrei na Universidade de Feira de Santana, eu fiz concurso, era uma coisa muito da minha vida. É interessante ilustrar isso, há quase vinte anos. Quando eu fui levar a minha documentação e preencher os documentos, fazer aquelas coisas de burocracia, a mulher que me atendeu era loira alta, de olhos azuis. Eu disse: "Olha, eu vim trazer a documentação". Ela me disse: "Não estamos contratando, não!" Eu disse: "Não, mas eu não vim para ser contratada; eu sou concursada". Ela não entendeu nada, depois entendi tudo. Ela nunca tinha visto uma professora tão negra, ou tão jovem. Eu disse: "Sou professora, fiz concurso, vim assinar o contrato". "Ah! Desculpe, professora, é que eu nunca tive uma experiência assim, uma professora tão jovem, né?” Não era tão jovem, era tão negra, isso sim. Isso foi assim uma coisa que marcou o início da minha carreira. Isso há vinte anos... Claro que hoje ninguém faz mais isso! (OLIVEIRA, 2006, p. 54).

Como é possível observar no relato da professora, a mulher negra não fazia parte do imaginário social correspondente a professoras universitárias. No final do seu relato, ela afirma que a situação vivida por ela, nesse dia, não acontece atualmente. Contudo, ao perguntar às/aos alunas/os sobre a quantidade de professoras/es negras/os atuando em suas escolas, percebe-se que, mesmo dez anos após a publicação do livro que traz o referido relato, esse imaginário não sofreu significativas transformações, pois as/os alunas/os, sobretudo as/os provenientes de escolas privadas, relataram ter poucas/os professoras/es negras/os. Da mesma forma, a presença de professoras/es negras/os nas universidades ainda é ínfima, como pode ser visto em uma reportagem de janeiro de 2016, na qual apenas $2 \%$ das/os professoras/es da UnB se consideram negras/os ${ }^{27}$. Tendo em vista que as/os negras/os representam $54 \%$ da população do país ${ }^{28}$, percebe-se que elas/es não se encontram devidamente representadas/os nesses espaços acadêmicos. É possível ainda que professoras/es universitárias/os negras/os não se veem ou se declarem com tais.

Esses dados nos mostram como as/os negras/os ainda encontram resistências para ultrapassar as barreiras impostas, não apenas pela classe social, mas também pela raça/etnia em nossa sociedade. Estamos acostumadas/os a ver negras/os em cargos inferiores não apenas na nossa realidade, mas também nos meios de comunicação em geral que ganham papel de destaque na construção do imaginário social do que é ser negra/o no Brasil. Com base nisso, problematizamos a supremacia branca trazida por hooks (2010) que afirma que, diferentemente do racismo, que busca excluir e fazer distinções, a supremacia branca é inconsciente e não significa necessariamente que as/os brancas/os desejam colocar as/os negras/os em uma posição de discriminação racista. Somos formadas/os em ambientes

\footnotetext{
27 Disponível em: <http://g1.globo.com/distrito-federal/noticia/2016/01/pioneira-em-cotas-raciais-unb-temmenos-de-2-de-professores-negros.html>. Acesso em: 4 abr. 2016, 19:34:56.

28 Disponível em: < http://economia.uol.com.br/noticias/redacao/2015/12/04/negros-representam-54-dapopulacao-do-pais-mas-sao-so-17-dos-mais-ricos.htm>. Acesso em: 3 out. 2016, 12:23:45.
} 
racistas, que exclui a/o negra/o dos acessos privilegiados da sociedade e que trazem impactos diretos na construção e ratificação da supremacia branca.

Considerando que as atitudes racistas nem sempre são conscientes, não nos damos conta delas. Um exemplo disso é o posicionamento das/os alunas/os diante da minha indagação. Ao questioná-las/os se eram racistas, poucas/os responderam afirmativamente. Mas ao perguntar se conheciam alguém racista, todas/os, sem exceção, responderam que sim. Nesse momento, trouxe a afirmação do sociólogo TELLES (2013) ao dizer que esse é o típico "racismo à brasileira": não somos racistas, mas conhecemos alguém que o é; não somos racistas, mas vemos a/o negra/o como inferior. Trouxe ainda a perspectiva de Munanga $(2013)^{29}$ ao ressaltar as dificuldades das/os brasileiras/os em reconhecer o racismo à brasileira uma vez que ele apresenta peculiaridades que o diferenciam de manifestações encontradas em outros países, como nos Estados Unidos e na África do Sul, por exemplo. Segundo o autor, a família, a escola, dentre outras instituições sociais propagam o mito de democracia racial brasileira, ratificando a crença de que não há racismo no Brasil. Isso nos mostra o quanto o racismo é difícil de ser erradicado da nossa sociedade. Por sermos formadas/os nesse contexto, não nos damos conta do quão ofensivas e discriminatórias nossas atitudes podem ser.

Após essa reflexão, foi entregue o questionário da Atividade VI (cf. apêndice 5). Nele, Roberta destacou ter se sentido, "curiosa sobre o mundo e o ponto de vista da sociedade". Anna W e Lauren afirmaram ter se sentido interessadas em discutir sobre o assunto.

Do item do questionário $O$ que você achou da atividade proposta?, destaco os seguintes comentários:

\footnotetext{
Interessante para conhecer como as pessoas são julgadas pela sua aparência e intrigada pelo fato de ainda haver muitos preconceitos (ANNA W).

Achei muito importante pois aprimora nossos conhecimentos sobre desigualdade e também melhora nosso vocabulário (BIEL).
}

Percebe-se que a atividade desenvolvida auxiliou as/os participantes a visualizar a maneira como as desigualdades, as práticas racistas e preconceituosas se encontram presentes na nossa realidade, além de aperfeiçoar o vocabulário da língua-alvo. Nesse sentido, Roberta

\footnotetext{
${ }^{29}$ Nessa afirmação, me baseio na videoaula referente à disciplina de Introdução à Teoria Social e Relações Raciais feita pelo autor e publicada em 14 de novembro de 2013. Disponível em: $<$ https://www.youtube.com/watch?v=7FxJOLf6HCA $>$. Acesso em: 23 abr. 2016, 20:34.12.
} 
ressalta que "discutir o tema em francês foi legal e diferente". É possível observar, na sua afirmação, que parece não ser comum discutir tais temas nas aulas de francês, chegando a ser diferente. No questionário inicial (cf. apêndice 1), 11 das/os 13 participantes relataram não ter discutido temas sociais nas aulas de francês em outros semestres. Dentre as/os outras/os 2 participantes, Lenor Estevão afirmou que "em outros semestres discutimos muito pouco temas sociais". Alexandre Agrigento destacou que "não 'discutimos'. Tópicos de desigualdade social foram mencionados". Diante disso, parece que as/os alunas/os não tiveram ou não se recordam de ter debatido, de fato, temas sociais na sala de aula de francês.

Ao analisar minhas aulas anteriores ao mestrado, percebo que não era comum problematizar temas críticos (URZÊDA FREITAS, 2013) em sala de aula, trabalhando questões de raça/etnia, gênero e sexualidade, por exemplo, enfatizando as relações assimétricas de poder entre as identidades. Geralmente, eu trabalhava com documentos que abordavam o tema já previsto no livro didático, que são, em geral, neutros e pasteurizados, ou eu propunha leitura de livros ou reportagens buscando alternativas de "sair" desse material. Contudo, eu não questionava as hierarquias ou relações de poder, não problematizava as práticas sociais.

Nesta pesquisa, por estar desenvolvendo um mestrado sobre gênero e raça/etnia e ter muitas leituras sobre o assunto, o ensino se revelou diferente. Eu trazia dados e informações para as aulas a fim de fomentar as discussões. A meu ver, não bastava pensar e refletir sobre o tema, era preciso "aprender" sobre ele, ter informações mais profundas e desenvolver a consciência crítica das/os alunas/os. A minha ansiedade e preocupação em ter o máximo de leituras possível trouxe, de certa forma, um peso para mim, pois eu tinha que ter algo a falar para elas/es, tinha que ter possíveis respostas.

Com a discussão dos dados, percebo que essa prática pedagógica não precisa ser um peso para a/o professor/a. Ela envolve proporcionar momentos de repensar as práticas sociais. Nesse sentido, as informações e os dados ajudam, mas é preciso ter em mente que não há repostas prontas ou verdades absolutas, mas sim possibilidades de repensar as práticas sociais da contemporaneidade. Para tanto, vale ressaltar a necessidade de estudos e formação docente adequada para que a/o professor/a possa se aprofundar nos temas e ter acesso a teorias acadêmicas que se voltam para essa perspectiva de ensino.

\subsubsection{Aula 24: 31 de maio de 2016}


Nesta aula, estavam presentes 12 alunas/os. Na lição do livro didático, estávamos estudando o presente do subjuntivo. Fizemos alguns exercícios de sistematização. Posteriormente, escrevi algumas frases no quadro que versavam sobre o que era preciso e importante fazer para termos uma sociedade mais justa e igualitária entre homens e mulheres. Escrevi quatro enunciados a esse respeito utilizando o subjuntivo. As frases se encontram a seguir:

Il faut que la société donne plus d'opportunité à la femme.

C'est important que la femme soit plus représentée dans la politique.

C'est utile que l'école discute la question de genre.

C'est possible qu'on ait une société plus juste.

Tradução:

É necessário que a sociedade dê mais oportunidade à mulher.

É importante que a mulher seja mais representada na política.

É útil que a escola discuta a questão do gênero.

É possível que tenhamos uma sociedade mais justa.

Fizemos a leitura dos enunciados e perguntei o que representavam. As/Os alunas/os afirmaram que eram conselhos a favor da mulher para diminuir as desigualdades e os preconceitos. Solicitei que formassem grupos de três pessoas e que complementassem esses conselhos. A ideia era que pudessem não somente trabalhar esse ponto gramatical como também refletir sobre as discussões anteriores, trazendo, para a prática, algumas possibilidades para construir uma sociedade mais justa e menos desigual. Ou seja, partindo da conscientização da realidade para, posteriormente, procurar transformá-la. Essa foi uma possibilidade encontrada para favorecer uma reflexão sobre as questões de gênero partindo do próprio conteúdo gramatical previsto no livro didático.

Fui guiando suas produções, passando de grupo em grupo e tirando as dúvidas que surgiam. Em seguida, pedi que lessem seus enunciados. Dentre eles, destaco alguns:

\footnotetext{
Alexandre Agrigento : Il faut que plus d'opportunités soient données aux femmes moins riches.

Lauren : Il est important que le respect soit pris en compte.

Lara : C'est important que la femme soit plus représentée à la culture, dans la littérature, dans les films et les jeux.

Roberta : C'est utile que tout le monde parle de ce sujet dans la maison.

Washington : C'est important que la femme gagne la même quatité d'argent que l'homme.

Johnson : C'est important que les enfants reçoivent plus d'éducation et de conscientisation dans la famille et dans l'école.

Cléo : C'est utile que les femmes soient motivées pour les sciences.

Biel : C'est important que la femme soit valorisée dans les moyens de communication.
} 


\section{Tradução:}

Alexandre Agrigento: É necessário que mais oportunidades sejam dadas às mulheres menos ricas.

Lauren: É importante que o respeito seja considerado.

Lara: É importante que a mulher seja mais representada na cultura, na literatura, nos filmes e nos jogos.

Roberta: É útil que todo mundo fale desse assunto em casa.

Washington: É importante que a mulher ganhe o mesmo que o homem.

Johnson: É importante que as crianças recebam mais educação e conscientização em casa e na escola.

Cléo: É útil que as mulheres sejam motivadas para a ciência.

Biel: É importante que a mulher seja valorizada nos meios de comunicação.

Tendo em vista os enunciados trazidos pelas/os alunas/os, é possível observar que elas/es trouxeram algumas possibilidades de mudanças para a nossa realidade. Lara sublinha a importância da representação das mulheres nos espaços protagonizados, sobretudo, por homens. Isso pode ser visto igualmente no enunciado de Cléo que acredita na educação diferenciada capaz de incentivar mulheres a visualizar e almejar profissões tidas como masculinas, demonstrando sua compreensão de que nossas escolhas profisssionais são socialmente construídas e influenciadas. Da mesma forma, Johnson e Roberta demonstram acreditar no papel da família, bem como da escola na formação de cidadãs/os críticas/os.

Por sua vez, Biel ressalta a valorização da mulher nos meios de comunicação destacando a importância de uma representação mais positiva, fugindo de estereótipos. Nesse momento, questiono sobre os meios de comunicação mais importantes. Elas/es mencionam a internet, a música, os jornais, os filmes, o cinema e as propagandas. Cléo comenta que somos muito influenciadas/os pela publicidade. Aproveito a oportunidade e questiono em quais propagandas a mulher está presente. $\mathrm{O}$ diálogo dessa interação encontra-se a seguir:

\section{Interação 17:}

Élèves : La mode, les manequins.

Johnson : Absorvente.

Élèves : [risos].

Professeure : Quoi d'autre?

Élèves : Les parfums.

Cléo : Coisas de casa.

Professeure : Oui, pour vendre des électro-ménagers (...) Qu'est-ce que ça représente pour la société ?

Lenor Estevão : Que les femmes doivent être à la maison.

Alexandre Agrigento : Mas é a realidade. Même si nous ne... gostamos?

Professeure : Nous n'aimons pas.

Alexandre Agrigento : Nous n'aimons pas, c'est une réalité.

Lenor Estevão : Oui, mais s'ils changent pour mettre un homme et une femme ou seulement un homme, changer , já não... [inaudível]

Alexandre Agrigento : Não vai mudar... [inaudível]

Professeure : Mais en fait qu'est-ce qui se passe ? Oui, Cléo. 
Cléo : Eu entendo o público-alvo de ser a mulher, só que podia ter variado né? De só as mulheres. Eu entendo isso de marketing, tipo você direcionar pro público-alvo, mas é importante a gente variar, porque realmente molda a mente.

Professeure : Parce que quand on voit une publicité comme ça, ok, ça représente la réalité, la grande réalite que ce sont les femmes qui sont à la maison, qui font la cuisine, qui lavent les choses. Mais si on continue à voir ce genre de publicité, quelles sont les conséquences?

Cléo : Nunca vai mudar.

(...)

Professeure : Donc si on ne change pas la publicité comment on va changer?

Alexandre Agrigento : Oui mais la publicité ne va pas changer...

Lenor Estevão : Oui, tu peux...

Alexandre Agrigento : Não, não vai...

Lenor Estevão : Mas eles são criticados...

Alexandre Agrigento : Parce que s'il y a plus femmes que hommes à travailler dans la maison, tu, dans la publicité, tu vas faire [inaudível] parce qu'elles sont dans la maison dans le moment...

\section{Interação 17 - Tradução:}

Alunas/os: A moda, as modelos.

Johnson: Absorvente.

Alunas/os: [risos].

Professora: O que mais?

Alunas/os: Os perfumes.

Cléo: Coisas de casa.

Professora: Sim, para vender aparelhos domésticos (...) O que isso representa para a sociedade?

Lenor Estevão: Que as mulheres devem ficar em casa.

Alexandre Agrigento: Mas é a realidade. Mesmo se nós não... gostamos?

Professora: Nous n'aimons pas.

Alexandre Agrigento: Nous n'aimons pas, é uma realidade.

Lenor Estevão: Sim, mas se eles mudam para colocar um homem e uma mulher ou somente um homem, mudar, já não... [inaudível]

Alexandre Agrigento: Não vai mudar... [inaudível]

Professora: Mas na verdade, o que acontece? Sim, Cléo.

Cléo: Eu entendo o público-alvo de ser a mulher, só que podia ter variado né? De só as mulheres. Eu entendo isso de marketing, tipo você direcionar pro público-alvo, mas é importante a gente variar, porque realmente molda a mente.

Professora: Porque quando a gente vê uma publicidade assim, ok, isso representa a realidade, a grande realidade que são as mulheres que ficam em casa, que cozinham, que lavam. Mas se a gente continuar a ver esse tipo de publicidade, quais são as consequências?

Cléo: Nunca vai mudar.

(...)

Professora: Então, se a publicidade não mudar, como vamos mudar?

Alexandre Agrigento : Sim, mas a publicidade não vai mudar...

Lenor Estevão : Sim, você pode...

Alexandre Agrigento : Não, não vai...

Lenor Estevão : Mas eles são criticados...

Alexandre Agrigento : Porque se tem mais mulheres que trabalham em casa do que homens, você, na publicidade, você vai [inaudível] porque elas estão em casa no momento...

No diálogo da interação 17, Cléo destaca a representação das mulheres nas propagandas relacionadas à venda de objetos para casa. Em sua fala, Lenor Estevão traz a importância de se mudar essa prática, pois, assim como pode ser visto no argumento de Cléo, tal representação influencia na construção dos papéis sociais atribuídos a homens e mulheres, 
reforçando o imaginário social do que ambos os gêneros devem ou não fazer na sociedade, ou ao menos, o que se espera deles.

A esse respeito, Carneiro (2004) ressalta que os meios de comunicação reforçam as representações sociais presentes no imaginário coletivo da sociedade destacando o seu poder para ratificar e cristalizar tais imagens. Em outras palavras, as imagens encontradas nas propagandas não apenas descrevem a realidade, como também a constroem. Daí a importância de procurar alterá-las, quebrando com estereótipos e trazendo outras possibilidades de percepção dos espaços sociais.

Interessante observar a reação de Alexandre Agrigento que, apesar do meu posicionamento e o de Lenor Estevão reforçando o discurso de Cléo, prossegue sua argumentação trazendo a percepção da realidade de que a publicidade não se modificará uma vez que as mulheres, ao trabalharem em casa, verão a publicidade e não os homens. Isso demonstra sua consciência crítica diante das situações do cotidiano.

Vale ressaltar que a interação 17 teve origem com o enunciado de Biel ao dizer que "é importante que a mulher seja valorizada nos meios de comunicação". Durante o semestre, Biel se destacou por ser um aluno muito responsável, sempre fazia os deveres de casa e prestava atenção às aulas. Contudo, ele não costumava se posicionar nas interações, exceto quando eu pedia sua opinião. Biel é estudante da rede pública de ensino e faz parte do convênio. Costumava se sentar ao lado de colegas da rede particular por terem estudado juntas/os no semestre anterior e conversar com elas/es, inclusive durante a pausa. Dessa forma, em nenhum momento senti uma hierarquia social ou racial em sala de aula, mesmo porque não havia alunas/os negras/os na sala e nenhum delas/es se considerou negra/o no questionário inicial. Porém, isso não significa necessariamente que as barreiras não estavam ali. Ao analisar as aulas, percebo que as/os alunas/os que mais participaram das interações e deixaram suas vozes serem ouvidas foram as/os de escola privada. Já as/os alunas/os da rede pública não participaram da mesma maneira, ficavam mais quietas/os, talvez por não acharem que tivessem o mesmo direito de participar, de se fazerem ouvir, de acreditar que tinham algo relevante a dizer. Lara e Robervaldo, também alunas/os do convênio, apesar de expressarem um pouco mais suas opiniões que Biel, não participavam tão ativamente das discussões. Lara demonstrou ser uma aluna muito atenciosa e reflexiva, ela parecia pensar sobre o que as/os colegas diziam, mas também não se posicionava constantemente. Por sua vez, Robervaldo entrou na turma um mês depois do início do semestre e faltou a algumas aulas, segundo ele, por motivo de saúde. No caso de Biel, acredito que a sua personalidade também tenha influenciado na sua participação em sala, pois ele sempre demonstrou ser muito tímido, 
inclusive nos momentos das pausas. Dentre as/os alunas/os do convênio, Manoca era o que mais participava, gostava de falar e conversar durante as aulas. Acredito que a personalidade aqui também tenha ajudado a ir além dessas fronteiras que se encontravam em sala de aula. Mesmo sem perceber, as barreiras de classe social pareciam estar presentes nesse ambiente de ensino, priorizando as participações. Daí a importância de transpor essas barreiras e mediar as interações, favorecendo e incentivando a participação de todas/os. Ademais, acredito que a menor participação por parte das/os alunas/os da rede pública advém também dos ambientes nos quais essas/es alunas/os se encontram inseridas/os, seja em casa ou até mesmo na escola, que ainda tende a não dar espaço para que as/os alunas/os possam expressar suas opiniões e discutir sobre temas críticos em sala de aula, favorecendo, assim, a reflexão, a agência e o engajamento no discurso. Nesse sentido, percebo que as/os alunas/os da rede privada demonstram ser mais críticas/os, apresentando um discurso mais engajado em seus posicionamentos e parecendo perceber as relações de poder entre as identidades.

Em seguida, desenvolvi a Atividade VII cujo objetivo era refletir sobre a desigualdade social entre mulheres brancas e negras, buscando compreender o processo histórico da escravidão e suas consequências na estrutura racial e social da sociedade.

No tópico seguinte, descrevo a referida atividade.

\subsubsection{Atividade VII: Ser mulher negra no Brasil}

A fim de problematizar a maneira como tais identidades se interseccionam trazendo diferentes perspectivas na vida das pessoas, discutimos sobre alguns dados estatísticos. Primeiramente, refletimos sobre os conceitos de misoginia, machismo e sexismo. Conceitos aparentemente prontos, apesar de não incomuns no cotidiano, precisam ser explorados em seus sentidos e significados, uma vez que concebo língua e linguagem aqui como prática social e simbólica (FAIRCLOUGH, 2008), isto é, cujos sentidos são criados e atribuídos socialmente. Por essa razão, explorar esses sentidos em sala de aula pode dar espaço para que os entendimentos sejam discutidos, por vezes ressignificados. Posteriormente, analisamos os dados de homicídios de mulheres brancas e negras a partir do gráfico encontrado no Mapa da Violência 2015 (BRASIL, 2015). 


\section{Imagem 8 - Homicídio de mulheres no Brasil}

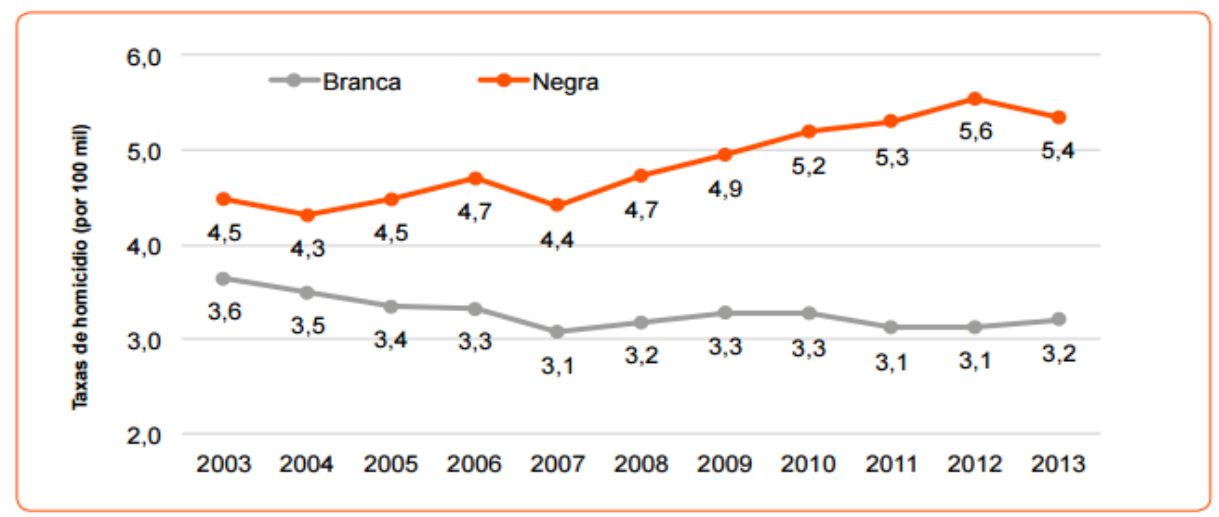

Fonte: Mapa da Violência 2015.

A partir desse gráfico, foi possível observar que o homicídio atinge muito mais as mulheres negras. Como é possível ver, de 2003 a 2013, a quantidade de homicídios de mulheres brancas caiu em 0,4 pontos ao passo que, no mesmo período, o homicídio de mulheres negras subiu 0,9 pontos. Por meio do gráfico, refletimos ainda que a Lei Maria da Penha possibilitou uma ligeira queda no número de homicídios de mulheres brancas e negras no ano seguinte a sua implementação em 2006, mantendo a taxa relativamente equilibrada para as mulheres brancas. Contudo, a partir de 2008, o número de homicídios de mulheres negras tende a subir consideravelmente nos anos seguintes, chegando ao seu ápice em 2012. Em vista disso, observamos, as/os alunas/os e eu, que a Lei trouxe muito pouco impacto na queda de homicídio de mulheres negras, que viu esse número crescer após a Lei. Dessa forma, verificou-se que a Lei beneficiou quase que exclusivamente mulheres brancas, mantendo relativamente a taxa após a sua queda em 2007. Além disso, observou-se que, quando se fala em homicídios contra mulheres no Brasil, as mulheres negras são as maiores vítimas.

Em seguida, passamos a refletir sobre a taxa de analfabetismo entre mulheres brancas e negras. Segundo o documento Retratos das Desigualdades de Gênero e Raça ${ }^{30}$ da Pesquisa Nacional por Amostra de Domicílios (PNAD)/IBGE com dados de 1995 a 2014, a taxa de analfabetismo da população analfabeta de 15 anos ou mais de idade era de 4.554 .707 para as negras e 1.988.459 para as brancas em 2014. Os dados mostram que o número de mulheres negras analfabetas acima de 15 anos era maior que o dobro de mulheres analfabetas brancas com a mesma idade.

Ao perguntar por que isso acontece, Cléo responde:

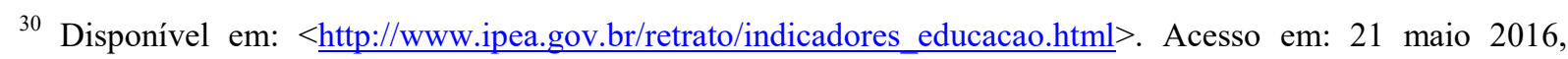
$11: 23: 45$.
} 
Cléo: Porque raça está muito ligada à classe social atualmente. Então, logo após o fím da escravidão, é, as oportunidades eram quase nulas para as pessoas negras, então, suprir as condições econômicas na nossa sociedade, ela é muito difícil e a escolarização também foi prejudicada por isso.

Em sua resposta Cléo destaca a relação estreita entre raça e classe social, categorias identitárias que influenciam no acesso de mulheres brancas e negras à educação. Nesse sentido, Telles (2003, p. 309) lembra que "a raça é um fator marcante para a exclusão social, criando uma estrutura de classes na qual os negros são mantidos nos níveis mais baixos". Da mesma forma, Cruz, Rodrigues e Barbosa (2011) apontam que a desigualdade social no Brasil apresenta um elemento racial.

As autoras ressaltam que, em um intenso estudo empírico patrocinado pela Unesco em 1950 a fim de analisar as relações raciais brasileiras, foi possível observar que os resquícios da escravidão ainda eram muito presentes no país e que a ausência de políticas públicas para integrar as/os ex-escravas/os na nova ordem social de trabalho relegou a/o negra/o à marginalização, impedindo-a/o de participar do plano político, econômico, social e cultural do país, além de dificultar sua transformação em cidadã/o. A esse respeito, Oliveira (2006) assevera que a escravidão e o autoritarismo contribuíram para o imaginário de inferioridade da/o negra/o. Segundo a autora, a "degenerescência do mestiço, o ideal de branqueamento e o mito da democracia racial foram mecanismos de dominação ideológica eficazes, que permanecem ainda hoje no imaginário social, o que tem dificultado a ascensão social da população negra e mestiça" (OLIVEIRA, 2006, p. 81).

Apesar das consequências do período colonial na estrutura social e racial da sociedade brasileira, Telles (2003) declara que as profundas desigualdades raciais não decorrem apenas da época da escravidão ou das desigualdades de classe, mas também de uma prática social corriqueira preconceituosa e de cunho racial que ainda persiste no país. O autor afirma que as desigualdades raciais no Brasil advêm principalmente de três aspectos: a grande desigualdade social, as barreiras discriminatórias que se fazem invisíveis e a cultura racista. Com efeito, o Brasil é um dos países com maior índice de desigualdade social do mundo e isso se manifesta, sobretudo, como barreiras de classe e de raça que dificultam o acesso de negras/os às camadas mais prestigiadas da sociedade. Da mesma forma, nossa cultura racista reforça estereótipos e preconceitos que excluem as/os negras/os cotidianamente.

Após as análises, questiono o porquê dessas diferenças na vida de mulheres brancas e negras: 


\section{Interação 18:}

Professeure : Pourquoi il y a ces différences? Comment expliquer ces informations?

Cléo : Parce qu'il y a deux sistèmes d'oppresion : c'est le genre et la race.

\section{Interação 18 - Tradução:}

Professora: Por que existem essas diferenças? Como explicar essas informações?

Cléo: Porque há dois sistemas de opressão: o gênero e a raça.

Ao trazer os dois sistemas de opressão sofridos pelas mulheres negras, Cléo demonstra, mais uma vez, perceber o impacto do gênero e da raça na vida dessas mulheres. Tal desigualdade advém, como foi possível observar nas análises anteriores, do período colonial. Nesse sentido, Carneiro (2004, p. 289) afirma que "o cruzamento entre patriarcalismo, escravidão e racismo irá determinar as trajetórias diferenciadas que mulheres negras e brancas trilharão no Brasil’". Daí a importância das lutas das mulheres negras dentro do movimento feminista. Com efeito, o movimento se iniciou por um seleto grupo de mulheres brancas de classe média alta e que tinha acesso à educação, saúde e lazer. Ou seja, por mulheres que se encontravam em um patamar social diferente de muitas outras, especialmente as negras. Como salienta hooks (2015), as mulheres privilegiadas buscavam igualdade de direitos sociais com os homens da sua classe, igualdade nos salários ou no estilo de vida. Dessa maneira, as feministas não tinham intenção de mudar, de fato, a estrutura da classe dominante. Na verdade, suas lutas se voltavam para a manutenção do status quo no que diz respeito à raça e à classe. Tratava-se de uma luta centrada nas opressões de gênero apenas. Não havia, portanto, uma preocupação com as mulheres negras que, além das opressões de gênero, sofriam também opressões impostas pela raça e pela classe social.

A partir dos dados analisados nessa atividade, percebe-se que, pouco mais de um século após a abolição da escravidão no Brasil, a população negra permanece à parte da sociedade. Como observam Cruz, Rodrigues e Barbosa (2011), as/os negras/os ainda não se encontram devidamente nos bancos das escolas, continuam ganhando menos em relação às/aos brancas/os e sofrendo de um racismo estrutural que as/os impede de ter acesso econômico e social.

Ao final da aula, foi entregue o questionário da Atividade VII (cf. apêndice 5). Nele, destaco alguns comentários. Do item $O$ que você achou da atividade?, selecionei os seguintes relatos: 
$\mathrm{Eu}$ achei muito interessante a atividade proposta, pois fiquei muito surpreso, impressionado e decepcionado com a diferença entre os negros e os brancos (JOSÉ).

Muito boa pois nos estimulou a pensar sobre como as mulheres negras são vistas como inferiores às mulheres brancas (BIEL).

A atividade proposta demonstrou [que] além de ter um preconceito contra mulheres, existe um preconceito entre raças (ROBERTA).

Gostei. É sempre bom ver estatísticas para entender que a situação é pior do que a gente pensa. Como sempre, a discussão foi interessante e estimulante (LENOR ESTEVÃO).

A proposta é interessante, dialogar e propor ideias para com a juventude atual. Saber a posição do adolescente em meio a realidade das mulheres e dos negros, para que haja uma posição (MANOCA).

Eu achei maravilhosa! Essa conscientização é muito importante!!! (CLÉO).

Nos relatos acima, Roberta demonstra perceber a dupla opressão de gênero e raça sofrida pelas mulheres negras. Em seus comentários, as/os alunas/os parecem perceber como essas opressões afetam a vida de mulheres negras que são vistas como inferiores.

O diálogo aqui se torna essencial para um pensar crítico, pois sem ele não há educação nem transformação (FREIRE, 2011). Concordo com o autor ao dizer que o diálogo é um ato de amor ao mundo e aos homens, ele é esperança. Em outras palavras, o diálogo é uma atitude de esperança para um mundo mais humano, onde a opressão não seja naturalizada.

Do item Como foi discutir o tema em francês?, selecionei os seguintes comentários:

Importante para o vocabulário (LAUREN).

Palavras novas (ROBERTA).

Ajuda a desenvolver minha linguagem (JOHNSON).

Discutir em francês foi bom para escutar (JOSÉ).

Foi um pouco difícil, mas mais fácil do que outras discussões que tivemos em francês (LENOR ESTEVÃO).

As/os alunas/os apontam em seus comentários pontos relativos à língua em si. Demonstrando a importância de discutir temas sociais em francês para o desenvolvimento discursivo da língua, bem como na aquisição de vocabulário. Como se pode perceber ainda no comentário de Lenor Estevão, as discussões parecem fluir mais facilmente para ela que utiliza o francês para expressar suas opiniões.

Do item $O$ que você aprendeu com a atividade?, destaco o comentário de Alexandre Agrigento: "Aprendi vários factos sobre a desigualdade entre mulheres brancas e mulheres negras especialmente. Também aprendi muito sobre o subjontif”. O comentário traz a relevância desse ensino não apenas para a conscientização crítica, mas também para o desenvolvimento linguístico das/os alunas/os que aprendem língua ao mesmo tempo em que refletem sobre questões sociais. Assim, é possível dizer que o LC favorece tanto a 
aprendizagem da língua como estrutura quanto como discurso. Aqui, foi possível trazer essa prática pedagógica para a sala de aula por meio do ensino da estrutura gramatical. Essa prática pedagógica favoreceu a problematização das desigualdades ainda existentes entre mulheres brancas e negras por meio de dados estatísticos.

\subsubsection{Aula 26: 07 de junho de 2016}

No início da aula, ao entrar em sala, as/os alunas/os estavam conversando sobre um caso de machismo que haviam visto na televisão e nas redes sociais. Estavam entusiasmadas/os e debatendo o assunto. Foi interessante vê-las/os dialogar e refletir entre si sem a minha presença naquele espaço. Elas/es pediram para conversarmos sobre o caso. Isso nos mostra, mais uma vez, como o letramento crítico na aula de línguas favorece um despertar para uma conscientização da realidade motivando as/os alunas/os a discutir sobre os eventos que nela se encontram.

Vale ressaltar que as/os alunas/os se mostravam cada vez mais interessadas/os e motivadas/os a discutir situações da realidade nas aulas de francês. Elas/es traziam, por conta própria, casos para serem debatidos em sala, como por exemplo: o estupro coletivo ocorrido contra uma jovem de 16 anos no Rio de Janeiro ${ }^{31}$, o assédio sexual do cantor Biel contra uma réporter $^{32}$ ou ainda o caso de Johnny Depp acusado de violência doméstica ${ }^{33}$. Além disso, elas/es propunham ver vídeos em sala, como o da Chimamanda Ngozi Adichie: "O perigo de uma história única"34 , bem como o da JoutJout Prazer: "Não é para sair" ${ }^{35}$ sobre o feminismo negro, dentre outros. Foi gratificante ver as/os alunas/os trazerem casos da vida cotidiana para serem discutidos em sala, ou seja, elas/es pareciam estar atentas/os ao que estava acontecendo no dia a dia, na vida real, e sentiam que a aula de francês era um espaço oportuno para discutir essas questões. Assim, propus criar um grupo no WhatsApp para que pudéssemos compartilhar documentos e informações sobre tais temas ao que as/os alunas/os concordaram.

Nesta aula, havia 10 alunas/os presentes. Em um primeiro momento, trabalhamos com o livro didático. Em seguida, desenvolvi a Atividade VIII (cf. apêndice 16). Na atividade que

\footnotetext{
31 Disponível em: <http:/g1.globo.com/rio-de-janeiro/noticia/2016/06/policia-conclui-inquerito-de-estuprocoletivo-no-rio-com-sete-indiciados.html>. Acesso em: 09 nov. 2016, 20:43:23.

32 Disponível em: <http://noticias.r7.com/domingo-espetacular/videos/-assedio-sexual-machismo-racismo-etransfobia-como-biel-destruiu-a-propria-carreira-07082016 $>$. Acesso em: 09 nov. 2016, 20:45:34.

${ }_{33}$ Disponível em: <http://ego.globo.com/famosos/noticia/2016/06/amber-heard-acusa-johnny-depp-de-violenciadomestica-em-depoimento.html > . Acesso em: 09 nov. 2016, 20:47:56.

${ }^{34}$ Disponível em: $<$ https://www.ted.com/talks/chimamanda_adichie the danger_of_a single_story?language $=$ ptbr>. Acesso em: 09 nov. 2016, 21:53:43.

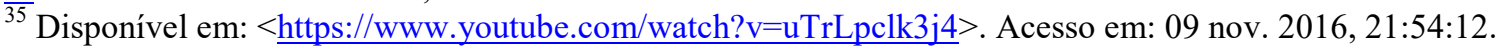


elaborei, o objetivo era analisar as percepções das/os alunas/os sobre o racismo no Brasil. Assim, busco refletir com elas/es sobre frases racistas e preconceituosas presentes em um ensaio fotográfico realizado na UnB.

A análise da atividade encontra-se na seção seguinte.

\subsubsection{Atividade VIII: $O$ racismo à brasileira}

$\mathrm{Na}$ sociedade brasileira ainda perdura o mito da democracia racial dando a falsa impressão de que somos todas/os iguais, com as mesmas oportunidades de acesso aos bens materiais e simbólicos. Tal concepção nega as diferenças raciais ou étnicas sugerindo um ideal implícito de homogeneização cultural e encobrindo os conflitos raciais (CRUZ; RODRIGUES; BARBOSA, 2011). Segundo Telles (2003), o Brasil ainda é um país racista, pois, ao mesmo tempo em que nega o preconceito racial, vê a/o negra/o como inferior. Para Gomes (2005a) esse racismo é ambíguo, pois se afirma na sua própria negação.

A fim de ter acesso às percepções das/os alunas/os sobre o racismo no Brasil e à maneira como ele se encontra presente na nossa sociedade questiono sobre sua existência:

\section{Interação 19:}

Professeure : Alors, vous pensez que le Brésil est un pays raciste?

Élèves : Oui.

Professeure : Pourquoi?

Anna W : Oui, mais non comme les autres.

Professeure : Oui, Robervaldo.

Robervaldo : Parce que les noires personnes... Recebem ?

Professeure : Reçoivent.

Robervaldo : Reçoivent moins d'argent que les blanches personnes.

Professeure : Aham. Pourquoi vous pensez que le Brésil est un pays raciste?

Anna W : Je ne pense que c'est raciste comme les autres pays en Europe.

Professeure : En Europe? Quels autres pays?

Anna W : France, Allemagne, l'Angleterre.

Professeure : Tu as déjà vu ou tu as déjà lu quelque chose ? Pourquoi tu penses que ces pays sont plus...?

Anna W : Parce que dans le Brésil il y a plus miscégénation.

(...)

Professeure : (...) quand on parle de cette miscégénation, on a l'impression que tout le monde est bien, qu'on est tous ensemble mais quand on va voir dans la réalité, où sont les blancs et les noirs ? (...) Par exemple, Anna W, dans ton école il y a des noirs?

Anna W : Oui.

Professeure : Si tu compares les noirs et les blancs, quelle est la différence?

Anna W : Il y a beaucoup de gens qui sont blanches que les noirs.

Professeure : Il y a plus de blancs que de noirs.

Anna W : Oui.

Interação 19 - Tradução: 
Professora: Então, vocês acham que o Brasil é um país racista?

Alunas/os: $\mathrm{Sim}$.

Professora: Por quê?

Anna W: Sim, mas não como os outros.

Professora: Sim, Robervaldo.

Robervaldo: Porque as pessoas negras... Recebem?

Professora: Reçoivent.

Robervaldo: Reçoivent menos que as pessoas brancas.

Professora: Aham. Por que vocês acham que o Brasil é um país racista?

Anna W: Eu não acho que seja racista como os outros países da Europa.

Professora: Da Europa? Que países?

Anna W: França, Alemanha, Inglaterra.

Professora: Você já viu ou leu algo? Por que você acha que esses países são mais...?

Anna W: Porque no Brasil tem mais miscigenação.

(...)

Professora: (...) quando a gente fala dessa miscigenação, a gente tem a impressão de que todo mundo está bem, de que estamos todos juntos, mas quando a gente vai ver na realidade, onde estão os brancos e os negros? (...) Por exemplo, Anna W, na sua escola tem negros?

Anna W: Sim.

Professora: Se você comparar os negros e os brancos, qual é a diferença?

Anna W: Tem muitas pessoas brancas que negras. [traduzindo de acordo com a frase dita em francês]

Professora: Tem mais pessoas brancas que negras.

Anna W: Sim.

Na interação 19, as/os alunas/os reconhecem a existência do racismo no Brasil. Anna W traz, na sua fala, o chamado mito da democracia racial que não dá conta da expressiva desigualdade social no país que separa brancas/os de negras/os e que, por sua vez, está diretamente relacionada com a raça (CRUZ; RODRIGUES; BARBOSA, 2011). Essa separação pode ser vista na escola particular onde ela estuda.

Observa-se que a mestiçagem entre as raças nos dá a falsa impressão de que aqui o racismo é menos agressivo e impactante. Contudo, apesar de não se dar da mesma forma como em outros países, o racismo brasileiro exclui as/os negras/os da sociedade impedindoas/os de ter acesso aos espaços mais valorizados.

Mais adiante, busco discutir um pouco mais sobre a miscigenação social, trazendo uma reflexão para o contexto social das/os alunas/os. Ao perguntar sobre a quantidade de alunas/os negras/os em suas respectivas escolas, elas/es se posicionam:

Dans mon collège, c'est plus pardo que preto (ROBERVALDO).

Il y a plus de gens blancs mais il y a des gens noirs. Comme c'est une école publique, la miscégénation c'est plus grande (LARA).

Il n'y a pas de brésilien noir (LENOR ESTEVÃO).

Il y a deux [brésiliens noirs] (ALEXANDRE AGRIGENTO).

Não tem muito (ROBERTA).

Il y a des noirs mais la majorité vient de Equador (LAUREN).

Majorité de blancs (WASHINGTON).

Il y a plus noirs que blancs (MANOCA). 
La grande majorité c'est blanche. Il y a des noir mais peu (JOSÉ).

\section{Tradução:}

No meu colégio, tem mais pardo que preto (ROBERVALDO).

Tem mais pessoas brancas que negras. Como é uma escola pública, a mestiçagem é maior (LARA).

Tem dois [negros] (ALEXANDRE AGRIGENTO).

Não tem muito (ROBERTA).

Têm negros, mas a maioria vem do Equador (LAUREN).

Maioria branca (WASHINGTON).

Têm mais negros que brancos (MANOCA).

A grande maioria é branca. Têm negros, mas pouco (JOSÉ).

A maioria das/os alunas/os que se expressou aqui se considerou branca/o no questionário inicial e é proveniente de escolas privadas, com exceção da Roberta que marcou a opção de cor “outro". Robervaldo e Manoca fazem parte do convênio com a SEEDF e se consideraram, respectivamente, pardo e amarelo. Lauren comenta que, das/os poucas/os alunas/os negras/os da sua escola, grande parte é de origem equatoriana. Já as/os alunas/os da rede pública afirmam ter uma maior miscigenação, geralmente com mais pardas/os ou negras/os. Isso nos mostra a segregação social e racial que ainda existe no Brasil. Mesmo que as barreiras discriminatórias sejam aparentemente invisíveis, elas funcionam para estabelecer os espaços sociais de brancas/os e negras/os na sociedade brasileira.

Continuo indagando para trazer a reflexão para o contexto da Aliança Francesa de Brasília, onde a pesquisa foi realizada:

\section{Interação 20:}

Professeure : À l'Alliance, vous avez déjà observé la couleur des gens à l'Alliance ? À part les étrangers, oui?

Roberta: Mas tem a escola pública.

(...)

Alexandre Agrigento : Je pense qu'à l'Alliance Française il y a diversité.

Professeure : Justement pourquoi?

Washington : Parce qu'il y a l'école publique.

Professeure : Parce qu'il y a le convênio et les élèves du public peuvent étudier ici, oui ? Mais sans le Convênio? Quand on observe juste les personnes du privé ?

Robervaldo : La majorité c'est blanche.

Professeure : La majorité des gens qui viennent du privé sont des blancs... Alors, où est la miscégénation?

\section{Interação 20 - Tradução:}

Professora: Na Aliança, vocês já observaram a cor das pessoas na Aliança? Com exceção dos estrangeiros, certo?

Roberta: Mas tem a escola pública.

(...)

Alexandre Agrigento: Eu acho que na Aliança Francesa tem diversidade.

Professora: Justamente por quê? 
Washington: Porque tem a escola pública.

Professora: Porque tem o convênio e os alunos da rede pública podem estudar aqui, certo? Mas, tirando o Convênio? Quando a gente observa apenas as pessoas das escolas particulares?

Robervaldo: A maioria é branca.

Professora: A maioria das pessoas que vêm de escolas particulares são brancas... Então, onde está a miscigenação?

$\mathrm{Na}$ AF de Brasília, a maioria das/os alunas/os são brancas/os. Em suas falas, Roberta, Alexandre Agrigento e Washington, alunas/os de escola particular, reconhecem que a diversidade na $\mathrm{AF}$ se dá devido ao convênio. É como se dissessem que, em suas escolas, não houvesse tal diversidade, mas um padrão branco, homogeneizado, ou pelo menos essa seria a expectativa. Tal percepção é reforçada por Robervaldo, aluno de escola pública, que percebe que a maioria das/os alunas/os provenientes de escolas privadas são brancas/os. O diálogo deixa claro qual é o lugar de cada um/a na sociedade. As/Os alunas/os já têm essa expectativa. Não significa que já tenham o desejo, mas sim a expectativa, isto é, estranhariam se uma situação diferente ocorresse.

Após a reflexão sobre o mito da democracia racial na nossa sociedade, passamos a refletir sobre alguns comentários racistas na UnB. Buscando desvendar o racismo velado na universidade, uma estudante de Antropologia fotografou pessoas que andavam pelo campus e pediu que escrevessem frases preconceituosas que já tinham ouvido. A proposta da atividade era refletir sobre tais frases (cf. apêndice 16), buscando saber o que pensavam a respeito delas:

\section{Interação 21:}

Professeure : Vous pensez que la réaction de ces personnes était, comment dire en français? Ils ont fait une montagne de tout ça ? Faire une montagne de quelque chose, ça veut dire, exagérer.

Roberta : Non.

Élèves : Non.

Professeure : Pourquoi non?

Manoca : Parce que c'est la réalité.

Lauren : Parce que c'est un droit d'être bien traité... [inaudível].

Professeure : Vous pensez que ça, c'est une raison d'offense ? C'est une raison pour manifester ? Ou ils exagèrent ? C'est normal ?

Manoca : C'est une raison.

Lauren : C'est normal mais não tinha que ser.

Professeure : Ça ne devrait pas être.

Manoca : Comment on dit comum?

Professeure : Commun. Ça arrive beaucoup mais ce n'est pas normal. Pourquoi tu dis que ce n'est pas normal Lenor Estevão?

Lenor Estevão : Parce que la couleur de ta pele ne dit pas comme tu es comme une personne, ta intelligence... 
Professora: Vocês acham que a reação dessas pessoas seria, como dizer em francês? Eles fizeram um escarcéu? Fazer um escarcéu significa exagerar.

Roberta: Não.

Alunas/os: Não.

Professora: Por que não?

Manoca: Porque é a realidade.

Lauren: Porque é um direito ser bem tratado... [inaudível].

Professora: Vocês acham que isso é motivo de ofensa? É uma razão para manifestar? Ou eles exageram? É normal?

Manoca: É uma razão.

Lauren: C'est normal mais não tinha que ser.

Professeure: Não tinha que ser.

Manoca: Coemo a gente diz comum?

Professora: Commun. Isso acontece muito, mas não é normal. Por que você diz que não é normal Lenor Estevão?

Lenor Estevão: Porque a cor da pele não diz como você é como pessoa, sua inteligência...

$\mathrm{Na}$ interação 21, percebo que a minha última pergunta “É normal?" trouxe ambiguidades nas respostas das/os alunas/os, mesmo porque a própria pergunta ficou generalizada, não sendo possível saber ao certo se eu questionava sobre o racismo presente nas frases ou sobre a atitude da reação das pessoas. Em todo caso, foi possível entender que as/os alunas/os percebem que a raça em si não define as capacidades de uma pessoa. A inferiorização advém de uma construção social que historicamente tem relegado a população negra a ocupar espaços desprivilegiados da sociedade.

Com essa atividade, busquei "superar os limites da pura razão e tocar no imaginário e nas representações" como aconselha Munanga (2005) a fim de encontrar alternativas para refletir sobre as discriminações raciais e a maneira como estão presentes em nossa sociedade.

Por meio dos enunciados analisados, conseguimos discutir sobre o racismo à brasileira. Tais enunciados continham ideologias racistas e preconceituosas, passando, muitas vezes, despercebidos nas diversas práticas sociais. Nesse sentido, Gomes (1996) observa que a discriminação racial não se dá necessariamente com hostilidade e agressão explícita à/ao negra/o, mas por meio de discursos. Daí a dificuldade de aferir o racismo na nossa sociedade.

A esse respeito, Gomes (2005b) reforça que, antes de encontrar estratégias para combater o racismo, é preciso reconhecê-lo na nossa sociedade. Munanga (2005) segue na mesma direção e afirma que isso requer desfazer a construção mental formada pelo mito da democracia racial.

Por falta de tempo, não entreguei o questionário da Atividade VIII, então perguntei em sala o que acharam da proposta e o que tinham aprendido com ela. Destaco aqui o comentário de Lauren que disse que "existe racismo nas pequenas situações da vida".

Mais uma vez, o LC favoreceu a interação em sala de aula abrindo espaço para a problematização do racismo no Brasil. O ensaio fotográfico se mostrou como uma 
possiblidade para trazer essa reflexão para a aula de francês e favorecer a ressignificação do mito da democracia racial em nosso país que ainda tende a esconder os conflitos raciais e sociais.

Apesar das inúmeras vantagens que essa prática pedagógica pode trazer, desenvolvê-la em sala de aula se mostrou um grande desafio para mim. Aqui compartilho com a/o leitor/a meus pensamentos e inquietações nesse sentido:

\begin{abstract}
Estou buscando me afastar das práticas educacionais tradicionais e neutras e provocar mudanças nos posicionamentos e nas práticas discursivas das/os alunas/os [...] Em minhas aulas, me vi buscando uma constante problematização e tentando encontrar um caminho para que minhas/meus alunas/os pudessem ter acesso às minhas leituras e informações, queria compartilhar com elas/es os conhecimentos que estou adquirindo no mestrado. Mas, ainda me sinto perdida de certa forma, sem saber se estou fazendo o que realmente deveria fazer, se falava mais que ouvia na tentativa de compartilhar esse conhecimento. Se errei, foi buscando acertar e acredito ter conseguido fazê-las/os refletir sobre os temas discutidos. (CADERNETA, 20 de maio de 2016).

O mais difícil para mim, ainda é encontrar as perguntas certas para ir tirando das/os alunas/os o que quero. Quando alguém me fala algo, estou acostumada a rebater trazendo explicações, mas com elas/es eu queria aprender a perguntar por que pensam como pensam e, a partir do que disserem, levantar outras questões, até se darem conta do porquê pensam da forma que pensam. Ou seja, ir desconstruindo o argumento com outras questões que as/os fazem pensar e refletir por si só, sem que eu dê muitas explicações e exemplos. (DIÁRIO DA PROFESSORAPESQUISADORA, 07 de junho de 2016).
\end{abstract}

Analisando os excertos extraídos do caderno que mantinha sempre comigo para anotações extras sobre a pesquisa, bem como do meu diário escrito após as aulas, percebo a minha preocupação em mudar minha práxis, bem como as concepções das/os alunas/os. Eu visava, de alguma forma, quebrar com preconceitos. De fato, no planejamento das aulas, buscava dados e informações no intuito de ajudar no desenvolvimento da consciência crítica das/os alunas/os. Procurava me informar para fomentar as discussões, organizar as ideias, problematizar e fazer refletir. Nesse sentido, as/os alunas/os podiam inclusive resistir e ir contra, fomentando ainda mais a discussão. Para tanto, desde o início da pesquisa, procurei criar um ambiente de confiança e respeito em sala de aula para que todas/os pudessem se expressar livremente. Além disso, trazia autoras/es que eu estava estudando no mestrado, suas ideias e pensamentos para que pudéssemos discutir sobre elas/es, pois gostaria de compartilhar o máximo possível das minhas leituras com as/os alunas/os.

Contudo, no letramento crítico não somos responsáveis por mudar as opiniões das/os alunas/os, muito menos de trazer verdades absolutas, uma vez que as informações e os 
conhecimentos são parciais, pois partem de um contexto sócio-histórico específico. Nosso papel envolve, portanto, favorecer a problematização das práticas sociais. A partir disso, surge outra inquietação: como problematizar? Como destaco no meu diário, minha preocupação era em como problematizar, que perguntas fazer. Procurava uma maneira "certa" de agir, de questionar as/os alunas/os. Mais uma vez, percebo que o letramento crítico não há regras a serem seguidas. Na verdade, são as interações em sala de aula que conduzem nossas ações, pois a maneira como agimos depende também da/o outra/o. Tendo em vista que não é possível prever a reação da/o outra/o, o que há são possibilidades de como desnaturalizar as identidades.

\subsubsection{Aula 27: 09 de junho de 2016}

Tendo em vista a atividade anterior na qual foi possível refletir sobre o racismo no Brasil por meio de algumas frases preconceituosas que demonstram como o racismo opera na nossa sociedade, busquei trazer uma reflexão para o contexto francês. Para tanto, desenvolvi a Atividade IX cujo objetivo era refletir sobre o racismo na França, por meio de perguntas e frases discriminatórias presentes no vídeo Les mots qui font mal.

O vídeo foi feito na França no intuito de mostrar como o racismo cotidiano está presente na sociedade. Ele traz imagens de pessoas de diversas origens, cores e religiões que são constantemente discriminadas, seja por sua raça/etnia ou por diferenças culturais que se diferenciam do padrão da/o nativa/o branca/o. À medida que as imagens vão passando, é possível ouvir pessoas fazendo perguntas como: "você é francês, mas você vem de onde?", "você fala Africano?", "você faz o Ramadan? Eu achei que você estivesse mais integrado". É possível ainda ouvir pessoas dizendo frases como: "você é até bonita para uma negra", "na sua família, fatalmente todas as mulheres portam o véu”, "os chineses são todos iguais", dentre outras. À primeira vista, tais perguntas e frases podem parecer ingênuas, mas agridem, ofendem e excluem. $\mathrm{O}$ vídeo se encontra no site que convida as pessoas a denunciar o chamado racisme ordinaire, ou seja, o racismo de todos os dias que atinge milhões de franceses e imigrantes. ${ }^{36}$

Nesta atividade, foi possível fazer um paralelo entre o racismo encontrado no Brasil e na França. Aqui, a discriminação está ligada, sobretudo, à cor e a características fenotípicas

\footnotetext{
${ }^{36}$ Disponível em: $<$ http://www.francetv.fr/temoignages/racisme-ordinaire/les-mots-qui-font-mal 100 > Acesso em: 11 nov. 2016, 00:56:23.
} 
(TELLES, 2003). Na Europa, o chamado "racismo cultural" se dá, não apenas pelas diferenças fenotípicas, estando, portanto, ligado a questões de raça/etnia, mas também a diferenças culturais como a língua e a religião, por exemplo (SANTERINI, 2015, p. 7).

Nesta aula, havia 12 alunas/os presentes. Na seção a seguir, faço a análise da referida atividade.

\subsubsection{Atividade IX: $O$ racismo cotidiano}

Antes de dar início à atividade propriamente dita, convidei as/os alunas/os a refletir sobre o conceito de racismo, bem como o sentido de racismo cotidiano. Tal termo nos remete ao racismo que passa, muitas vezes, despercebido aos olhos das/os outras/os, porém não para aquelas/es que sofrem esse tipo de discriminação. Tendo em vista que os significados não estão prontos e acabados e que os sentidos são construídos em contextos específicos (Menezes de Sousa, 2011a), é relevante refletir sobre as concepções que o termo pode adquirir em diferentes situações.

Em vista disso, refletimos sobre o conceito de discriminação racial trazido pela Convenção das Organizações das Nações Unidas em 1966 sobre a eliminação de todas as formas de discriminação racial. $\mathrm{O}$ documento afirma que discriminação racial significa

\footnotetext{
qualquer distinção, exclusão restrição ou preferência baseadas em raça, cor, descendência ou origem nacional ou étnica que tem por objetivo ou efeito anular ou restringir o reconhecimento, gozo ou exercício num mesmo plano (em igualdade de condição), de direitos humanos e liberdades fundamentais no domínio político econômico, social, cultural ou em qualquer outro domínio de vida pública. ${ }^{37}$
}

Assim, não apenas as exclusões e distinções, mas também as preferências baseadas na cor ou na origem de uma pessoa capazes de restringir o gozo de seus direitos humanos constitui-se caso de discriminação racial. Isso se torna relevante para se pensar no racimo em todas as suas formas, sejam elas sutis ou não.

Inicio a interação questionando as/os alunas/os sobre o racismo na França a fim de verificar suas percepções sobre esse aspecto:

\footnotetext{
${ }^{37}$ Disponível em: < http://legis.senado.gov.br/legislacao/ListaTextoIntegral.action?id=94836 $>$. Acesso em: 02 out. 2016, 17:06:24.
} 
Interação 22:

Professeure : Vous pensez qu'il y a du racisme en France?

Élèves : Oui.

Professeure : Comment est le racisme en France?

Johnson : C'est avec les immigrants.

Alexandre Agrigento : C'est quand [a pessoa] dit 'mais tu es d'où vraiment ?' 'Vraiment ?'

Lenor Estevão : 'Oui, mais vraiment?'

Interação 22 - Tradução:

Professora: Vocês acham que existe racismo na França?

Alunas/os: Sim.

Professora: Como é o racismo na França?

Johnson: É com os imigrantes.

Alexandre Agrigento: É quando [a pessoa] diz 'mas você é de onde de verdade?' 'De verdade?'

Lenor Estevão: 'Sim, mas de verdade?'

Diante da minha pergunta, Johnson traz a ideia do racismo cultural ressaltado por Santerini (2015), um racismo que se baseia nas diferenças culturais e que exclui da mesma forma que os demais. Alexandre Agrigento e Lenor Estevão demonstram ter uma percepção mais detalhada da situação ao mencionar a pergunta geralmente feita aos franceses de origem estrangeira, como também aos imigrantes.

A partir da resposta de Alexandre Agrigento e Lenor Estevão, mostrei o vídeo Les mots qui font mal. Após a visualização, perguntei o que ele retrata:

Interação 23:

Professeure : De quoi il s'agit cette vidéo ? Qu'est-ce que vous avez vu dans cette vidéo ?

Johnson : Des phrases, des préjugés...

Élèves : Des stéréotypes.

José : Beaucoup de choses mauvais pour une personne.

Professeure : Qui font mal, oui?

Cléo : Il y a aussi la marginalisation des personnes nées en France mais filles d'immigrants. Et la société française... faz você se sentir?

Professeure : La société française les fait sentir...

Cléo : Les fait sentir qu'ils ne sont pas français.

Professeure : Est-ce qu'il y a du racisme ici [no vídeo] ?

Élèves : Oui.

Professeure : Et comment le racisme, il est exprimé en France, d'après la vidéo ?

Manoca : Ils comparent é... Eles...

Lara : Les questions.

Manoca : Les pays.

Professeure : Parce que le racisme au Brésil, il est très lié à la... ?

Johnson : Le visage.

Professeure : La couleur et aux phénotypes (...) En France, le racisme, il est lié à quoi ?

Manoca : La nationalité.

Roberta : À descendência. 


\section{Interação 23 - Tradução:}

Professora: De que trata esse vídeo? O quê vocês viram nesse vídeo?

Johnson: Algumas frases, preconceitos...

Alunas/os: Estereótipos.

José: Muitas coisas ruins para uma pessoa.

Professora: Que fazem mal, certo?

Cléo: Têm também a marginalização das pessoas nascidas na França, mas filhos de imigrantes. E a sociedade francesa... faz você se sentir?

Professora: A sociedade francesa os faz sentir...

Cléo: Os faz sentir que não são franceses.

Professora: Será que tem racismo aqui [no vídeo]?

Alunas/os: Sim.

Professora: E como o racismo acontece na França, de acordo com o vídeo?

Manoca: Eles comparam e.... Eles...

Lara: As perguntas.

Manoca: Os países.

Professora: Porque o racismo no Brasil é muito ligado à... ?

Johnson: À aparência.

Professeure: À cor e aos fenótipos (...) Na França, o racismo está ligado a quê?

Manoca: À nacionalidade.

Roberta: À descendência.

$\mathrm{Na}$ interação 23, as/os participantes afirmam existir racismo na França. Diante do meu questionamento a respeito da maneira como esse racismo é praticado no país, Manoca menciona a comparação geralmente feita entre os países. A partir das perguntas e frases do vídeo, entende-se que tais comparações têm como referência a/o francesa/francês branca/o e a sua cultura. Em outras palavras, há a valorização da cultura francesa em detrimento das demais.

Tais atitudes demonstram o tipo de racismo encontrado atualmente na Europa conhecido por racismo cultural ou "néo-racismo" (SANTERINI, 2015, p. 1). Diferentemente do racismo tradicional, baseado na hierarquia de raças, esse novo racismo, também chamado pela autora de "racismo sem raça" 38 , uma vez que o próprio conceito de raça foi negado pela ciência, é baseado nas diferenças culturais (SANTERINI, 2015, p. 6). Citando o sociólogo e politólogo Pierre-André Taguieff, a autora observa que a desvalorização pode decorrer da aparência física, sobretudo a cor da pele, tendendo a enfatizar as características culturais, dentre elas a religião. Ou seja, o racismo cultural, assim como o nosso, também está ligado a questões de raça/etnia, baseado no fenótipo que se difere do padrão branco europeu e, a partir daí, as diferenças culturais são enfatizadas.

Segundo Santerini (2015, p. 6), esse racismo é baseado em uma "hierarquia de culturas ${ }^{39}$, podendo parecer mais sutil que o racismo tradicional, porém apresenta os mesmos

\footnotetext{
${ }^{38}$ Tradução de: Racisme sans race.

${ }^{39}$ Tradução de: Hiérarchie des cultures.
} 
objetivos e efeitos: "ele visa "explicar e legitimar comportamentos ou discursos discriminatórios e contribui para alimentá-los" ${ }^{\wedge 0}$. Dessa forma, a autora reforça que

\begin{abstract}
essa ideia ganha forma de um etnocentrismo radical que visa avaliar ou julgar os outros grupos em função do seu próprio, que é considerado perfeito. Ele pode consistir na desvalorização de qualquer cultura diferente da sua ou a forçar sua assimilação. Esse fenômeno alimenta os preconceitos diante dos outros, sobretudo os imigrantes, e está se desenvolvendo em vários Estados membros do Conselho da Europa. (SANTERINI, 2015, p. 6). ${ }^{41}$
\end{abstract}

O racismo cultural pode se dar, portanto, pela cor da pele, pela religião, pela língua, ou seja, tudo aquilo que se diferencia da cultura da/o nativa/o branca/o. A autora reforça que o discurso do racismo cultural tende a ser banalizado, normalizando os preconceitos racistas e contribuindo para a propagação da discriminação contra grupos minoritários.

O vídeo nos ofereceu a oportunidade de refletir sobre o chamado néo-racismo ou racismo cultural, presente em vários países da Europa, bem como suas particularidades. No final da aula, entreguei o questionário da Atividade IX (cf. apêndice 5). As/Os participantes destacaram, em seus relatos, a importância da atividade para possibilitar um entendimento das diferentes formas de racismo em contextos sociais variados. Assim, foi possível fazer um diálogo com a atividade anterior que destacou as particularidades do racismo no Brasil.

Com relação ao fato de discutir o tema em francês, Lenor Estevão destacou que "foi mais fácil do que das outras vezes", demonstrando estar desenvolvendo suas capacidades discursivas. Possivelmente, ela estaria se sentindo como usuária da língua, pois as/os alunas/os estão interagindo e discutindo sobre questões reais que fazem parte de suas vidas. Acredito que essa prática pedagógica coloca as/os alunas/os em posição de cidadãs/os, ou seja, pessoas que pensam a vida na cidade, que dividem o espaço social chamado cidade, portanto, são responsáveis por ele também, sendo, assim, um diferencial.

Alexandre Agrigento ressaltou: "acho que correu bem e toda a gente tentou falar". De fato, as/os alunas/os buscaram falar mais em francês nessa aula, inclusive a Cléo que, muitas vezes, tende a se expressar em português. Talvez isso tenha acontecido por estarem se sentindo mais à vontade e confiantes para usar o francês no intuito de expressar seus

\footnotetext{
${ }^{40}$ Tradução de: Il vise à expliquer et légitimer des comportements ou discours discriminatoirs, et contribue à les alimenter.

${ }^{41}$ Tradução de: Cette idée peut prendre la forme d'un ethnocentrisme radical, qui revient à évaluer ou juger les autres groupes en fonction du sien, que l'on considère comme parfait. Il peut consister à rejeter toute culture diferente de la sienne ou à forcer son assimilation. Ce phénomène alimente les préjugés envers les autres, notamment les migrants, et apparaît en développement dans plusieurs Etats membres du Conseil de l'Europe.
} 
sentimentos e pontos de vista sobre as situações. Seria possível dizer que, com o tempo, o letramento crítico poderia formar alunas/os/cidadãs/os mais preparadas/os para participar dos debates e embates dentro e fora da sala de aula, tanto em língua materna quanto na língua estrangeira?

A respeito da atividade, Roberta afirmou ter achado "bem interessante como há diferentes tipos de racismo em diferentes lugares”. Lenor Estevão destacou ter aprendido "muito acerca da sociedade francesa e dos imigrantes lá". Seguindo na mesma direção, Washington relatou que aprendeu "o racismo no dia-a-dia e a diferença do racismo no Brasil e na França". Lenor Estevão e Washington parecem simplificar suas respostas com enunciados pacificados e pasteurizados. Apesar de a atividade ter contribuído para refletir sobre o racismo em outros contextos sociais, uma aula não seria suficiente para aprender "muito" sobre um aspecto cultural. Na verdade, nem mesmo anos em um lugar podem necessariamente nos ensinar sobre a sociedade e seus imigrantes. Da mesma maneira, Washington ressalta a diferença do racismo na França e no Brasil, porém, não faz menção às suas semelhanças ou ainda ao fato de que ambos os racismos produzem igualmente opressões, discriminações e desigualdades. Contudo, considero que esta atividade favoreceu a reflexão sobre as maneiras pelas quais o racismo se encontra presente na França. $O$ vídeo foi uma possibilidade de abordar esse tema em sala, uma maneira de trazer o LC para esse contexto de ensino, desenvolvendo a identidade das/os alunas/os como usuárias/os da língua, bem como o seu senso crítico na formação de futuras/os cidadãs/os.

\subsubsection{Aula 28: 14 de junho de 2016}

Nessa aula, as/os alunas/os comentaram sobre o fim do semestre que se aproximava. Perguntaram se eu daria aula para elas/es novamente. Disse que não seria possível, pois estaria analisando os dados para a pesquisa, mas que viria para visitá-las/os, o que de fato o fiz no semestre seguinte. Manoca perguntou sobre o tema da pesquisa. Ressaltei que o objetivo era desenvolver um trabalho de LC na aula de línguas. Enfatizei que o letramento é o uso da escrita e da leitura para participar das diferentes práticas sociais. Assim, ele implica uma reflexão daquilo que ouvimos e lemos, buscando analisar quem escreve, para quem, com qual objetivo, além de contrapor diferentes pontos de vista. Ademais, o LC visa ainda analisar os impactos daquilo que lemos e ouvimos em nossas vidas.

Dessa forma, destaquei que essa prática pedagógica busca um estímulo para a conscientização crítica da realidade. Ao refletir sobre gênero e raça/etnia na aula de línguas, o 
objetivo é perceber como essas categorias sociais estão presentes na sociedade, como elas se interseccionam, produzindo diferentes tipos de discriminação e opressão (HOOKS, 2015).

Desenvolvi a última atividade do semestre buscando refletir com as/os alunas/os, em um primeiro momento, sobre as pessoas presentes nas capas de revista em uma imagem presente no livro didático. Em um segundo momento, analisamos algumas capas das revistas Elle France $^{42}$, Vogue France ${ }^{43}$, Elle Brasil ${ }^{44}$ e Vogue Brasil ${ }^{45}$. O objetivo era discutir e refletir sobre o padrão de beleza presente nessas capas.

A escolha das revistas se deu, primeiramente, por se tratar de revistas de moda renomadas. Além disso, elas existem na versão francesa e brasileira, sendo possível fazer uma comparação entre elas.

A análise dessa atividade encontra-se a seguir.

\subsubsection{Atividade X: A representação da mulher negra nas capas de revistas}

$\mathrm{Na}$ atividade proposta pelo livro didático, havia uma imagem com diferentes capas de revistas para que as/os alunas/os pudessem identificar o nome e as informações veiculadas por cada uma delas. Após ter feito as atividades previstas por esse material, chamei atenção para as pessoas presentes nas capas:

\footnotetext{
${ }^{42}$ Disponível em:

$<$ https://www.google.com.br/search?q $=$ elle + france\&espv $=2 \& b i w=1517 \& b i h=708 \&$ source $=1 n m s \& t b m=i s c h \& s a$ $=\mathrm{X} \& v e d=0$ ahUKEwjJhsnilq7PAhXHTJAKHe3aCeEQ AUIBigB\&dpr $=0.9 \#$ imgrc $=\mathrm{W} \_2 \mathrm{~W} 44 \mathrm{~s} 0 \mathrm{RYgCoM} \% 3 \mathrm{~A}>$ . Acesso em: 13 jun. 2016, 09:54:02.

${ }^{43}$ Disponível em:

$<$ https://www.google.com.br/search?q=elle+france\&espv=2\&biw=1517\&bih=708\&source=lnms\&tbm=isch\&sa $=X \& v e d=0$ ahUKEwjJhsnilq7PAhXHTJAKHe3aCeEQ AUIBigB\&dpr $=0.9 \#$ tbm $=$ isch\&q $=$ Vogue + france\&imgrc $=\mathrm{gWrVmKyJuFVBLM} \% 3 \mathrm{~A}>$. Acesso em: 13 jun. 2016, 10:13:34.

${ }^{44}$ Disponível em:

$<$ https://www.google.com.br/search?q=elle+france\&espv=2\&biw=1517\&bih=708\&source=lnms\&tbm=isch\&sa $=\mathrm{X} \& v e d=0$ ahUKEwjJhsnilq7PAhXHTJAKHe3aCeEQ AUIBigB\&dpr $=0.9 \#$ tbm=isch \&q $=$ elle + brasil\&imgrc $=\mathrm{Z}$ 9rO8KOL-x9YvM\%3A>. Acesso em: 13 jun. 2016, 10:35:23.

${ }^{45}$ Disponível em:

$<$ https://www.google.com.br/search?q=elle+france\&espv=2\&biw=1517\&bih=708\&source=lnms\&tbm=isch\&sa $=\mathrm{X} \& v e d=0$ ahUKEwjJhsnilq7PAhXHTJAKHe3aCeEQ AUIBigB\&dpr $=0.9 \#$ tbm=isch\&q=vogue + brasil\&imgrc $=$ F3sNGCDIyB3ztM\%3A>. Acesso em: 13 jun. 2016, 11:02:45.
} 
Imagem 9 - Capas de revistas do livro didático

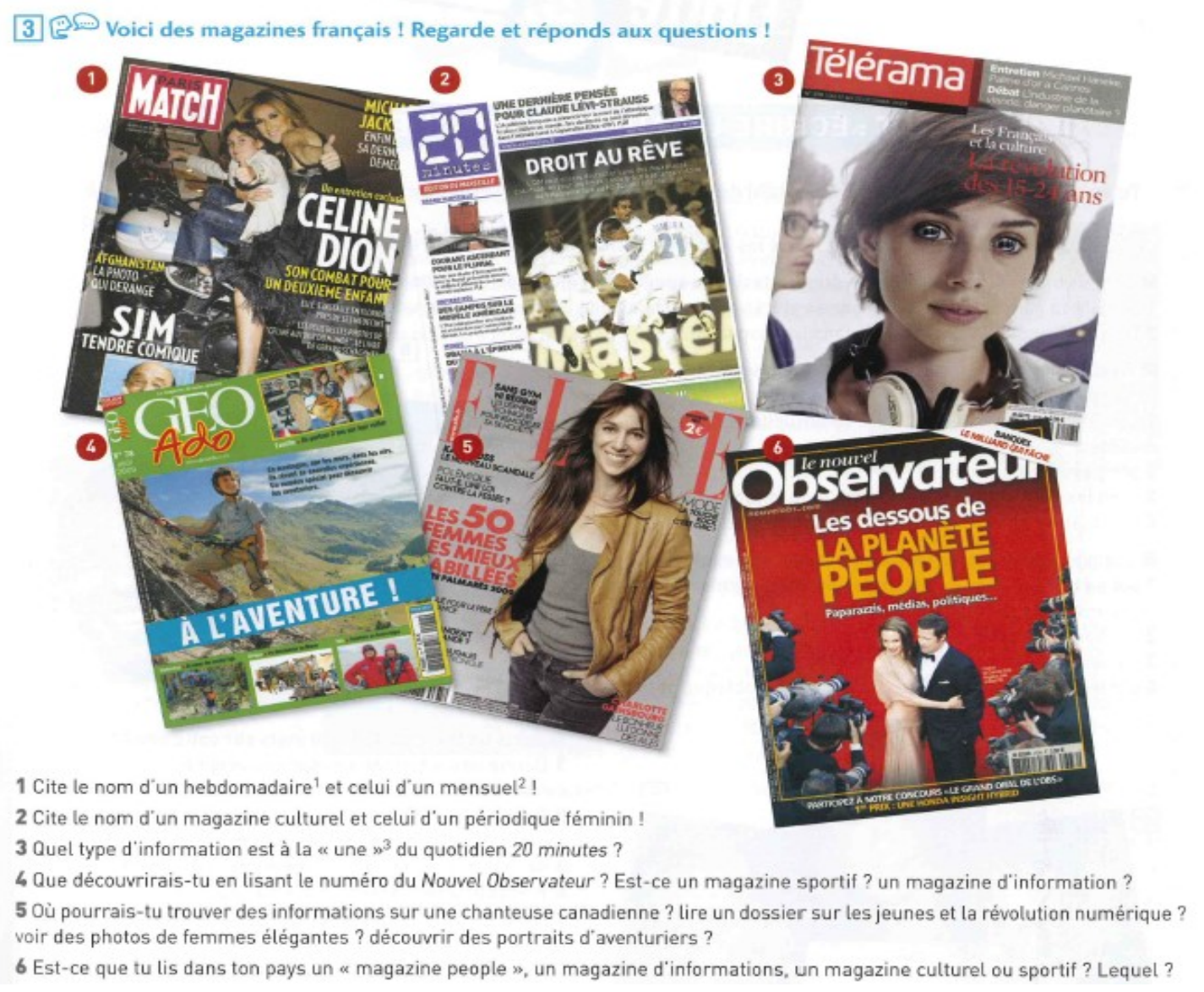

Fonte: Amis e compagnie 4, p. 45.

O diálogo dessa interação encontra-se a seguir:

\section{Interação 24:}

Professeure : Classe, qu'est-ce que vous voyez sur ces couvertures? Qui sont les gens qui sont sur ces couvertures?

Cléo : Bred Pitt et Angelina Jolie.

Anna W : C'est les femmes maigres, é tall...

Professeure : Grandes...

Anna W : Grandes [risos] et bruns...

José : Blanches.

Washington : Ela tá com preconceito já.

Anna W : Ah mais é.

Professeure : Anna W, tu peux répéter? Qui sont les gens sur ces couvertures?

Anna W : En général, à cette revista, à cette couverture de mode, sont les femmes maigres, grandes et blanches.

\section{Interação 24 - Tradução:}

Professora: Turma, o que vocês veem nessas capas? Quem são as pessoas presentes nessas capas?

Cléo: Bred Pitt e Angelina Jolie.

Anna W: Mulheres magras e tall... 
Professeure: Altas...

Anna W: Altas [risos] e morenas... [pessoas com cabelos pretos]

José: Brancas.

Washington: Ela tá com preconceito já.

Anna W: Ah mais é.

Professora: Anna W, você pode repetir? Quem são as pessoas nas capas?

Anna W: Em geral, nessa revista, nessas capas de moda, são mulheres magras, altas e brancas.

Diante do meu questionamento, Anna $\mathrm{W}$ percebe rapidamente o padrão da mulher branca, alta e magra. Washington, por sua vez, parece questionar o posicionamento da colega como se ela estivesse vendo coisas além do que supostamente deveria ser visto. Anna W demonstra desenvolver seu olhar crítico para as situações e, ao fazê-lo, consegue perceber modelos de mulheres que representam um padrão de beleza tido como privilegiado, excluindo quem nele não se encaixa.

Buscando melhor visualizar esse padrão, passamos a ver algumas capas de revistas conhecidas. Ao ver as imagens da Vogue France, José se posiciona:

\section{Interação 25:}

José : C'est toutes femmes blanches. Il n'y a pas de noire.

Anna W : C'est un padronnage.

Manoca : Personnes riches.

Cléo : Beaucoup de femmes blanches.

\section{Interação 25 - Tradução}

José: São todas mulheres brancas. Não têm negras.

Anna W: É um padrão.

Manoca: Pessoas ricas.

Cléo: Muitas mulheres brancas.

Como foi de se esperar, as mulheres presentes nas capas eram brancas. Ao analisar Elle France, a situação não muda muito, mas as/os alunas/os encontram algumas fotos de mulheres negras:

\section{Interação 26:}

Cléo : Ah tem a Lupita, acho que é a Lupita ali, né não?

Roberta : É a Lupita ali.

Cléo : Nossa, uma.

Professeure : Une femme noire. Qui est cette femme?

Élèves : Lupita Nyong'o.

Anna W : C'est actrice.

Professeure : C'est une actrice, très célèbre. 
Cléo : É, doze anos de escravidão.

Professeure : Et pourquoi vous pensez... Washington, on y va ? Pourquoi vous pensez que Lupita est sur cette couverture?

Anna W : Parce qu'elle est célèbre. Elle est belle.

\section{Interação 26 - Tradução:}

Cléo: Ah tem a Lupita, acho que é a Lupita ali, né não?

Roberta: É a Lupita ali.

Cléo: Nossa, uma.

Professora: Uma mulher negra. Quem é essa mulher?

Alunas/os: Lupita Nyong'o.

Anna W: Ela é atriz.

Professora: É uma atriz muito famosa.

Cléo: É, doze anos de escravidão.

Professora: E por que vocês acham... Washington, vamos? Por que vocês acham que Lupita está nessa capa?

Anna W: Porque ela é famosa. Ela é bonita.

Aqui, foi possível verificar que, quando havia uma mulher negra na capa, geralmente era uma mulher famosa. Apesar de Anna W ressaltar a beleza da atriz, ela parecia estar ali, muito mais devido à sua notoriedade do que por sua beleza, tendo em vista que ela não se encaixa no padrão de beleza geralmente encontrado nas revistas de moda. Ainda na mesma revista, elas/es encontraram outra mulher negra:

\section{Interação 27:}

Professeure : Par exemple ici, il y a une autre femme noire.

Élèves : É uma mulher?

Cléo : Acho que é uma mulher.

Professeure : C'est une femme politique française.

Cléo : Ah, je ne connais pas.

Professeure : C'est très rare d'avoir des femmes politiques françaises noires. Et là elle dit 'Je ne crains ni le racisme, ni le sexisme, ni la bétise'.

(...)

Professeure : Donc vous voyez que quand il y a une femme noire...

José : Il y a des choses de racisme.

Professeure : Vous voyez ? Quand il y a une femme noire, soit elle est très célèbre, soit c'est pour parler...

Anna W : De le racisme.

Manoca : Caraca, é verdade.

\section{Interação 27 - Tradução:}

Professora: Por exemplo, aqui tem outra mulher negra.

Alunas/os: É uma mulher?

Cléo: Acho que é uma mulher.

Professora: É uma mulher política francesa.

Cléo: Ah, eu não conheço.

Professora: É raro ter políticas francesas negras. E aqui ela diz: 'Não temo nem o racismo, nem o sexismo, nem a estupidez'.

(...)

Professora: Então, vocês percebem que quando tem uma mulher negra... 
José: Têm coisas de racismo.

Professora: Vocês percebem? Quando tem uma mulher negra, ou ela é famosa, ou é para falar...

Anna W: De racismo.

Manoca: Caraca, é verdade.

Nesse caso, especificamente, a mulher negra presente na capa de revista não era tão conhecida internacionalmente. Porém, ao ler o enunciado estampado na capa, chamei a atenção para o seu significado. Nesse momento, José percebe o tema do racismo.

$\mathrm{Na}$ interação 27, observei que, quando uma mulher negra apareceu na capa de revista, foi devido a dois fatores principais: sua celebridade e sua autoridade para falar por um grupo de mulheres que sofre com a discriminação racial.

Ao analisar a versão brasileira de ambas as revistas, não encontramos diferenças significativas. Ou seja, os fenótipos da/o negra/o ainda não são devidamente valorizados no Brasil, que, apesar de ser o segundo país do mundo com a maior população negra (HERINGER, 2001), ainda valoriza um padrão branco. Nesse sentido, encontrou-se a negra de pele clara que tende a ser sexualizada no país.

Após identificarem uma celebridade negra em uma capa da Vogue Brasil, refletimos sobre sua aparência:

\section{Interação 28:}

Professeure : Là c'est une noire, mas ce n'est pas n'importe quelle noire. C'est qui ?

Élèves : Naomi Campbell.

Professeure : Une manequin très célèbre.

Élèves : Oui.

Professeure : Et regardez... comment sont les cheveux ?

Élèves : Lisses.

Professeure : Pourquoi?

Washington : Préjugé ça.

Anna W : Pour être plus féminin.

Manoca : Não gente, talvez seja opção dela.

Cléo : Não, é para se conformar aos padrões eurocêntricos.

Interação 28 - Tradução:

Professora: Aqui, temos uma negra, mas não é qualquer negra. Quem é?

Alunas/os: Naomi Campbell.

Professora: Uma modelo muito famosa.

Alunas/os: Sim.

Professora: E olhem... como estão os cabelos?

Alunas/os: Lisos.

Professora: Por quê?

Washington: Preconceito isso.

Anna W: Para ficar mais feminino.

Manoca: Não gente, talvez seja opção dela.

Cléo: Não, é para se conformar aos padrões eurocêntricos. 
$\mathrm{Na}$ interação 28, foi possível observar que as mulheres negras presentes nas capas apresentavam, geralmente, características da mulher branca. Ao analisar outras capas, percebeu-se que as mulheres negras estavam, em sua grande maioria, com cabelos lisos, tinham o nariz fino ou ainda os olhos verdes. Isso mostra que o padrão de beleza da mulher, no Brasil, ainda tem sua base no eurocentrismo, como ressalta Cléo. A valorização desse padrão foi construída desde o período colonial. Segundo Carneiro (2004, p. 291), a consagração do padrão de mulher branca como o referencial privilegiado em detrimento da mulher negra decorre da visão desta como "pau pra toda a obra", distanciando-a da visão “idílica da mulher consagrada na tradição cultural patriarcal" ancorado no mito da fragilidade feminina. Dessa forma, a autora frisa que a raça ou a cor determina a negação da condição feminina que, no caso da mulher negra, se encontra em uma zona indefinida entre o masculino e o feminino. Tal situação pode ser encontrada no comentário de Anna W que identifica o cabelo liso como mais feminino. A partir disso, é possível também refletir sobre o comentário de Manoca e questionar: até que ponto nossas preferências estão baseadas naquilo que queremos ou naquilo que a sociedade já pré-estabeleceu como belo?

Refletimos ainda sobre as consequências desse padrão na vida das mulheres em geral, e, particularmente, das mulheres negras, que se veem pressionadas a serem magras, altas e, de preferência, a apresentarem características do fenótipo branco. As barreiras encontradas pelas mulheres negras são tantas chegando a haver revistas específicas para elas. A revista Amina, por exemplo, é uma revista feminina francófona conhecida por ser uma revista de mulheres africanas e antilhanas. Por sua vez, no Brasil, a revista Raça Brasil é especificamente voltada para negras/os.

Essa atividade favoreceu a reflexão sobre o padrão branco privilegiado nas revistas de moda da França e do Brasil nas quais a mulher branca representa a norma. Dessa forma, percebeu-se que a mulher negra não representa nem a beleza francesa, nem a brasileira ficando fora da imagem do que é considerado belo nessas sociedades. Isso traz impactos diretos na autoestima das mulheres negras que tentam se aproximar de uma norma ocidental, apagando seus traços físicos naturais.

Vale ressaltar que essa atividade foi baseada em algumas atividades presentes no livro didático. A esse respeito, Ferreira e Brigolla (2013) ressaltam que as/os professoras/es podem se servir do livro didático para ir além das regras gramaticais, favorecendo a inserção de temas ligados à realidade das/os alunas/os. Elas apontam a possibilidade de fazê-lo a partir de 
uma imagem, como no caso desta atividade, que, geralmente, é utilizada somente como condutor dos exercícios.

Tendo em vista ser o livro didático o principal material usado em sala de aula, tais imagens "influenciam a construção identitária do aluno, reproduzem ideologias, participando de modo importante da formação de atitudes e valores." (OLIVEIRA, 2008, p. 99 apud FERREIRA; BRIGOLLA, 2013, p. 5). Dessa forma, torna-se relevante problematizar as identidades presentes nesse material, favorecendo a reflexão crítica das/os alunas/os para que possam melhor compreender sua própria realidade.

O livro didático se mostrou, mais uma vez, como uma possibilidade de problematizar identidades sociais de gênero e raça/etnia na sala de aula de francês como língua adicional. Ele propiciou a problematização sobre o padrão de beleza valorizado nas revistas de moda e sua influência na manutenção do status quo que tende a excluir mulheres negras que não se encaixam nesse padrão eurocêntrico.

Tendo até aqui apresentado à/ao leitor/a descrições e discussões das aulas e da prática pedagógica empreendida na pesquisa, retomo a minha inquietação apresentada no início deste capítulo diante da observação da professora regente sobre o nível fraco nas habilidades orais e escritas das/alunas/os e o uso do português em sala. Analisando as interações, percebo que a grande maioria delas se deu na língua francesa. As/os participantes se expressaram e refletiram sobre questões sociais por meio da língua-alvo, agindo diferentemente do que foi relatado pela professora. Ao longo do semestre, percebi o desenvolvimento linguísticodiscursivo das/os alunas/os que buscavam usar a língua francesa cada vez mais nos seus posicionamentos. De maneira geral, elas/es utilizaram o português para complementar ideias ou para expressar mais a fundo suas opiniões.

Acredito que o uso da língua-alvo se deve ao clima de confiança encontrado nesse ambiente de ensino e, sobretudo, às oportunidades que elas/es tiveram de falar sobre assuntos de seus interesses. Isso pôde ser visto nas ações das/alunas/os ao trazerem casos para serem debatidos em sala, vendo a aula de francês como uma oportunidade de discutir sobre eles. Assim, é possível dizer que o LC favoreceu não apenas o desenvolvimento das capacidades linguístico-discursivas das/os alunas/os, como também a formação de cidadãs/os mais críticas/os e atentas/os aos eventos presentes em suas vidas.

Na seção seguinte, faço a discussão das produções escritas realizadas ao longo do semestre.

\subsection{Discussão das produções escritas}


Durante o semestre, foram feitas duas produções escritas (cf. apêndices 7 e 8). Em ambas as produções, a tarefa dada foi: as/os alunas/os tinham que escrever um texto em francês para o editorial do jornal de suas escolas sobre o tema solicitado. Para cada produção, os seguintes temas foram pedidos:

Produção Escrita I - A construção do gênero masculino e feminino na sociedade: origens e consequências dessa construção.

Produção Escrita II - As desigualdades entre mulheres brancas e negras: origens, consequências e possíveis soluções para reverter a situação.

O objetivo das produções era ter acesso aos possíveis desdobramentos do trabalho com LC nas percepções das/os alunas/os quanto às identidades sociais de gênero e raça/etnia, analisando a maneira como elas/es percebem a dinâmica dessas identidades na sociedade, bem como na formação crítica e no desenvolvimento da agência das/os participantes.

Para a discussão dos dados, selecionei alguns excertos dos textos das/os alunas/os que se mostraram mais pertinentes para ter acesso à maneira como elas/es entendiam e percebiam as identidades sociais. Desses excertos, selecionei ainda um enunciado que me chamou atenção e o coloquei no tópico da imagem que nomeia cada um deles. Nas traduções, prezo o sentido dos enunciados, fazendo alguns ajustes para melhor compreensão do texto uma vez que não é o objetivo da pesquisa analisar o conhecimento linguístico-discursivo na línguaalvo das/os participantes.

A seguir, faço a discussão dos textos da primeira produção escrita.

\subsubsection{Produção Escrita I}

A primeira produção foi solicitada após as atividades abordando gênero, mais especificamente no dia 17/05/16. Assim, eu buscava verificar o que ficou das reflexões e discussões feitas em sala de aula, seus possíveis desdobramentos na (re)construção das identidades sociais de gênero, bem como na formação de cidadãs/os críticas/os. As/os alunas/os Lara, Washington e Lenor Estevão não fizeram a Produção Escrita I. As discussões são feitas com base na maneira como as/os alunas/os abordaram o tema: os primeiros humanos, biologia versus sociedade; os brinquedos; as crianças e, finalmente, a importância da igualdade feminina.

Abordando os primeiros humanos, Anna W ressaltou a concepção de gênero como construção social, diferentemente do sexo, que é definido biologicamente: 


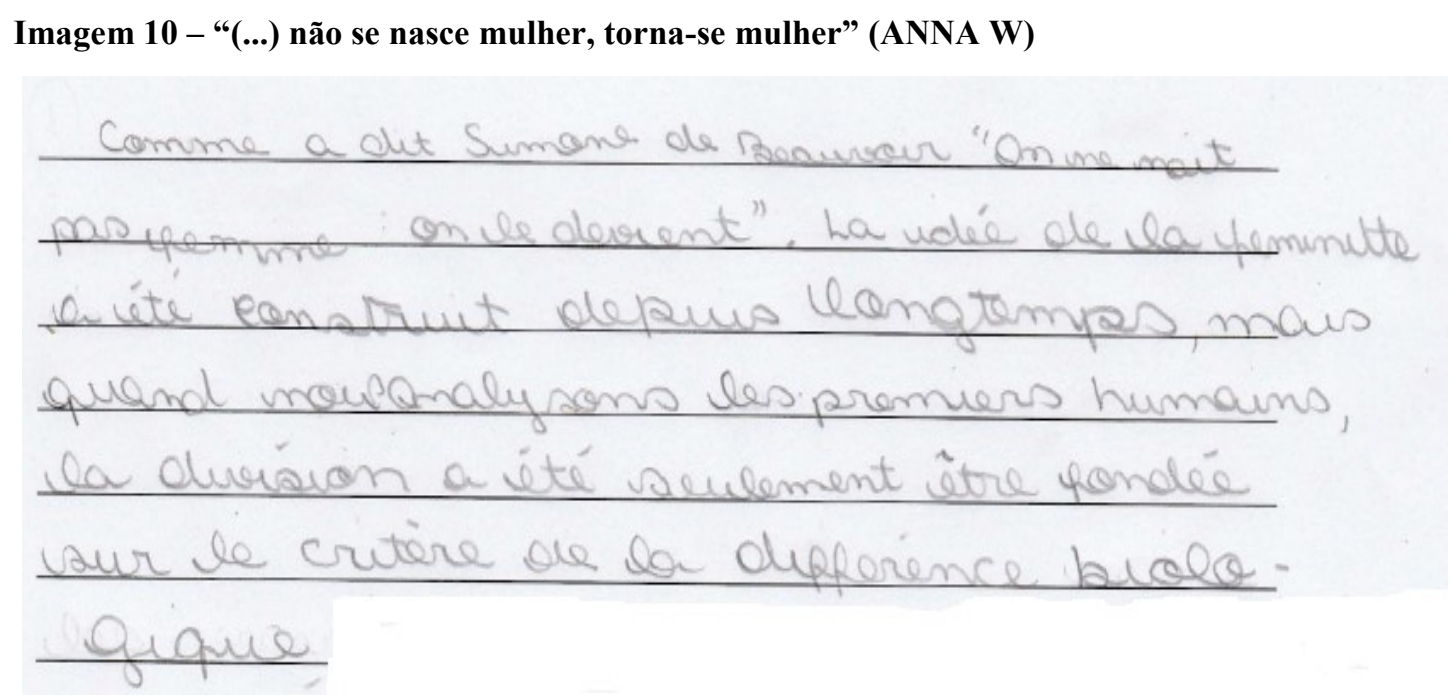

Fonte: Produção Escrita I

Tradução: Como disse Simone de Beauvoir "Não se nasce mulher, torna-se mulher". A ideia da feminista foi construída há muito tempo, mas quando analisamos os primeiros humanos, a divisão [do trabalho] foi fundada apenas pelo critério da diferença biológica (...) (ANNA W).

Ao trazer Simone de Beauvoir, Anna W, conforme se pode ver na imagem 10, frisa a importância do contexto social para a construção do gênero feminino, descartando concepções naturalizadas da conduta feminina. Contudo, ela aponta que a divisão feita entre homens e mulheres se deu a partir do sexo biológico. Ou seja, apesar de a participante demonstrar reconhecer a construção social do gênero, ela parece entender as diferenças nas atribuições profissionais de homens e mulheres como decorrentes do sexo e não da sociedade. A essa respeito, Louro (2003, p. 21) afirma que, "seja no âmbito do senso comum, seja revestido por uma 'linguagem científica', a distinção biológica, ou melhor, a distinção sexual, serve para compreender - e justificar - a desigualdade social”. Para a autora, não são exatamente as características sexuais que resultam em desigualdades, mas o que se pensa a respeito dessas características e o valor que lhes é dado é que vai constituir o que é feminino e masculino em uma dada sociedade em um determinado momento histórico.

Assim, é possível dizer que, mesmo na pré-história, os papéis sociais atribuídos a homens e mulheres eram muito mais incentivados pelos valores conferidos a essas funções do que propriamente pelas diferenças entre os sexos. Isso vai influenciar nos espaços sociais ocupados por cada um/a na sociedade, gerando inúmeras desigualdades sociais. A participante parece, então, se basear em discursos propagados pelo senso comum que tendem a naturalizar as diferenças nas atividades profissionais de homens e mulheres como advindas de suas especificidades biológicas e não dos valores sociais atribuídos a tais atividades. 
O aluno Johnson ressalta a relação biologia versus sociedade em seu texto:

Imagem 11 - “(...) as bases da sociedade humana são construídas por dois gêneros (...)” (JOHNSON).

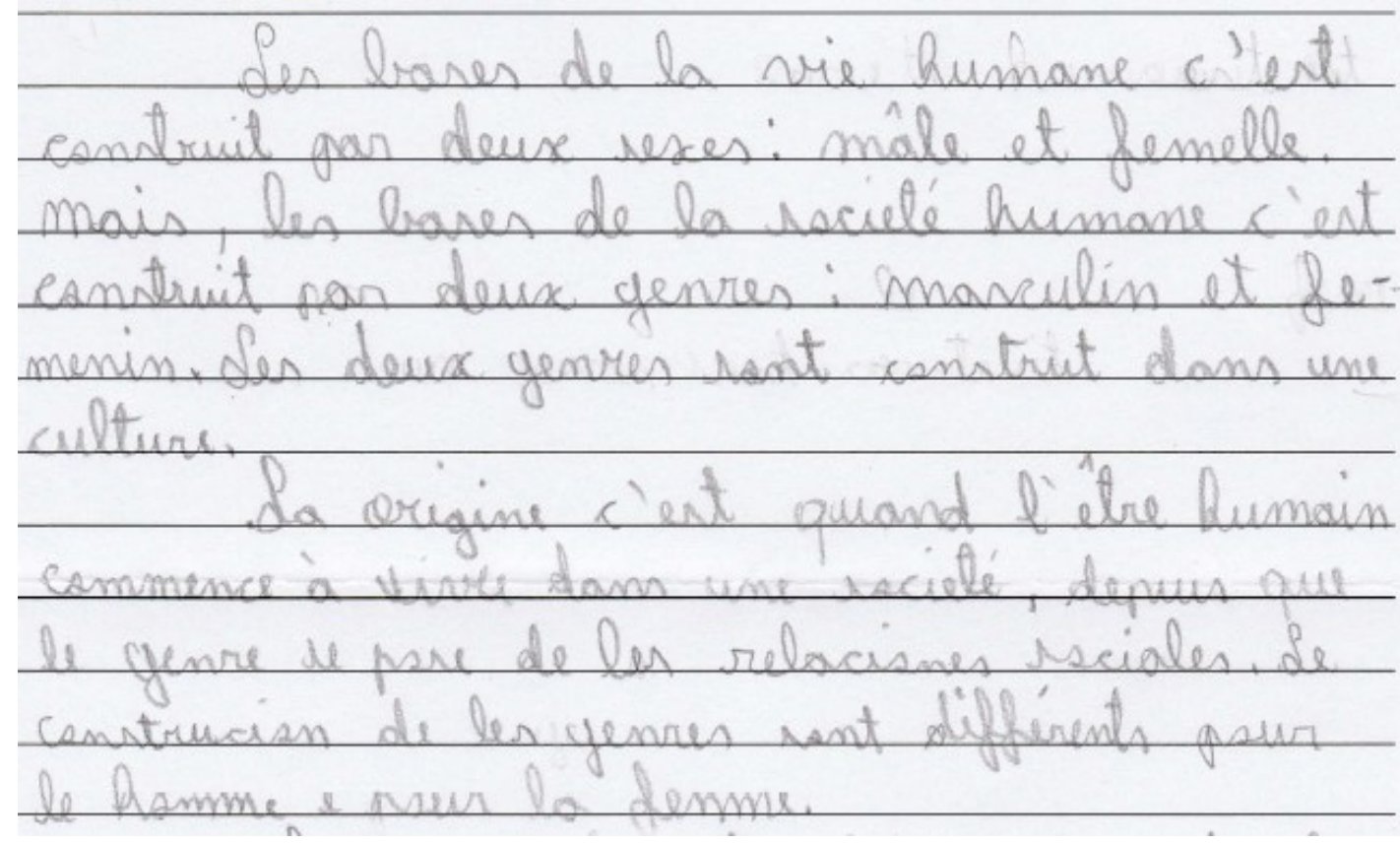

Fonte: Produção Escrita I

Tradução: As bases da vida humana são construídas por dois sexos: macho e fêmea. Mas as bases da sociedade humana são construídas por dois gêneros: masculino e feminino. Os dois gêneros são construídos em uma cultura. A origem é quando o ser humano começa a viver em sociedade, uma vez que o gênero se passa nas relações sociais. A construção dos gêneros são diferentes para o homem e para a mulher (JOHNSON).

Conforme pode ser visto na imagem 11, Johnson enfatiza o caráter biológico do macho e da fêmea como as bases da vida humana. Já as noções de masculino e feminino, que correspondem ao gênero, são sociais e culturais. Ele demonstra entender tais concepções como as bases da sociedade humana, enfatizando o lado social na construção do gênero, sendo, portanto, diferente para homens e mulheres.

Biel também ressalta a diferença entre sexo e gênero. Pare ele, o sexo está ligado a características biológicas e o gênero à maneira pela qual uma pessoa se identifica, ressaltando o caráter social na construção da identidade de gênero. Para ele, uma pessoa deveria ser reconhecida na sociedade pelo gênero com o qual se identifica e não pelo sexo definido no nascimento. Além disso, ele evidencia a discriminação sofrida pelas pessoas que não se enquadram nessas construções: 
Imagem 12 - "A identidade de gênero é saber como um indivíduo se identifica na sociedade (...)" (BIEL).

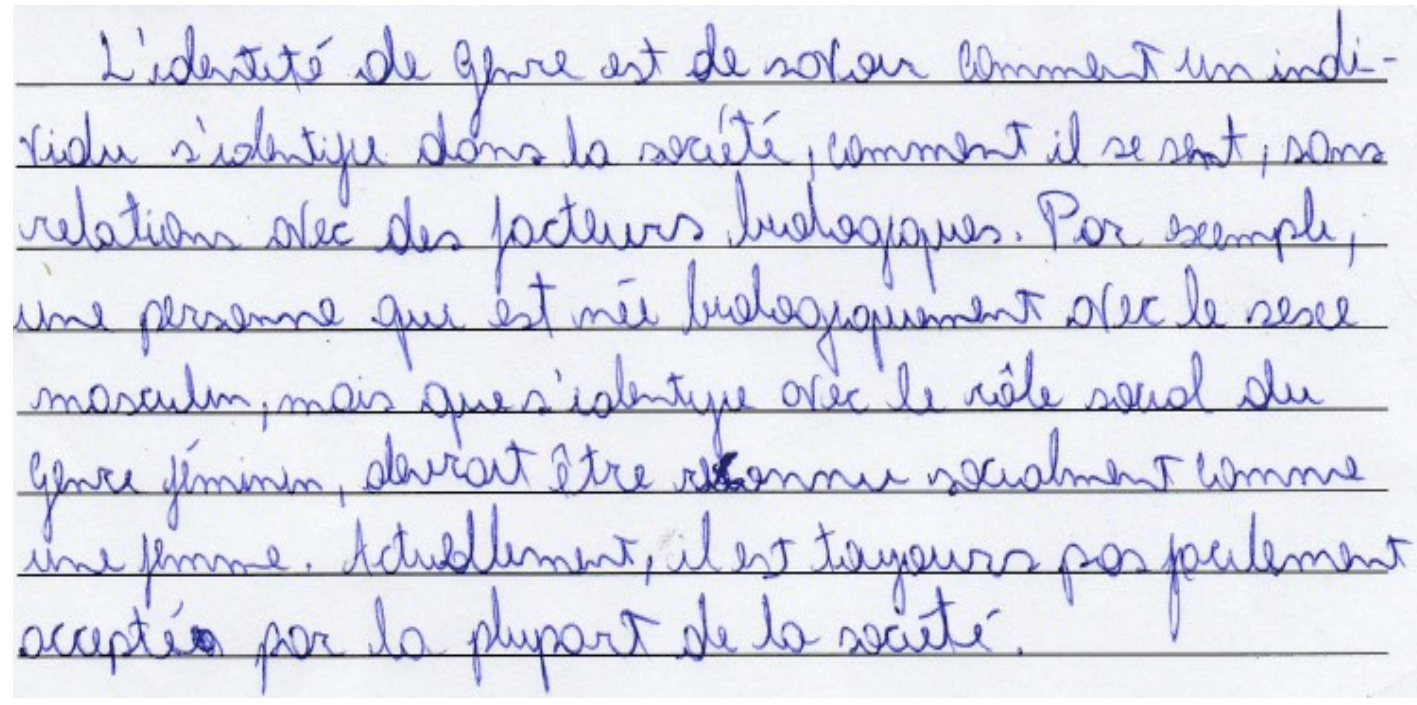

Fonte: Produção Escrita I

Tradução: A identidade de gênero é saber como um indivíduo se identifica na sociedade, como ele se sente, sem relação com fatores biológicos. Por exemplo, uma pessoa que nasceu biologicamente do sexo masculino, mas que se identifica com o papel social do gênero feminino, deveria ser reconhecido socialmente como uma mulher. Atualmente, ainda não é fácil [ser] aceito pela maior parte da sociedade (BIEL).

Biel traz em seu texto uma perspectiva mais social que envolve as múltiplas formas de viver os gêneros, se contrapondo à noção singular de masculino e feminino que negam os sujeitos sociais que não se "enquadram” em uma dessas concepções (LOURO, 2003, p. 34). Nesse sentido, ele transgride as fronteiras opressoras de dominação impostas pelo gênero, como sugere hooks (2013), demonstrando entender as identidades de gênero como socialmente construídas e ligadas à maneira como a pessoa se vê situada no mundo. José segue na mesma direção, ressaltando a importância da liberdade para que o sujeito possa ser o que quiser:

Imagem 13 - “(...) Eu sou o que eu quiser ser (...)” (JOSÉ).

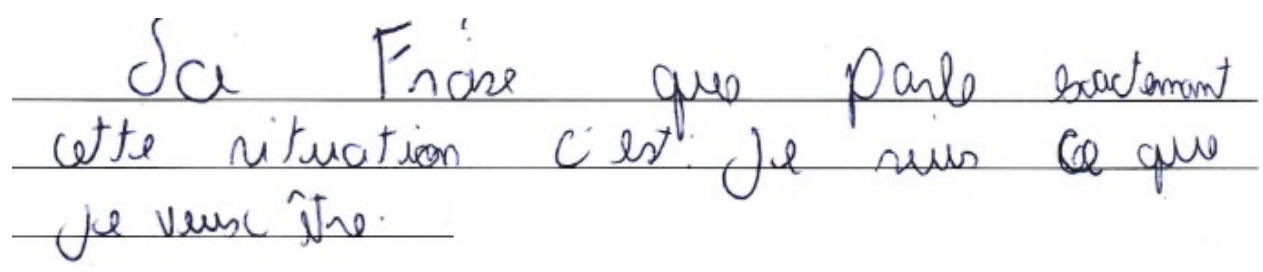

Fonte: Produção Escrita I

Tradução: A frase que fala exatamente essa situação é que eu sou o que eu quiser ser (JOSÉ). 
Mesmo sendo o aluno mais novo da turma, com 14 anos, José demonstra ter uma compreensão menos preconceituosa e estereotipada das identidades de gênero.

Lauren menciona as diferenças de brinquedos dados a meninos e meninas e suas implicações em suas vidas profissionais:

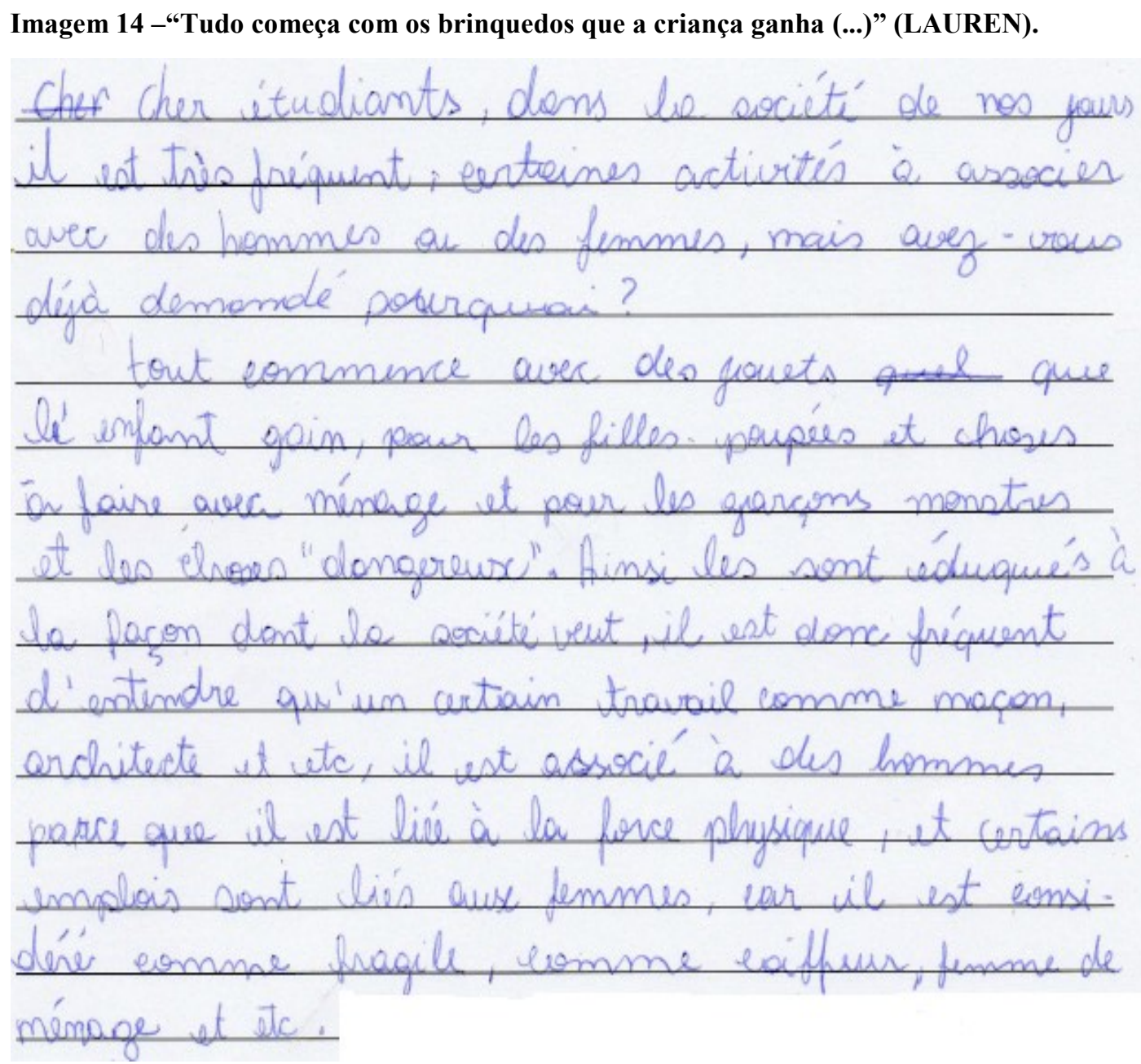

Fonte: Produção Escrita I

Tradução: Caros estudantes, na sociedade atual é muito comum algumas atividades a associar com os homens ou as mulheres, mas vocês já se perguntaram por quê?

Tudo começa com os brinquedos que a criança ganha, para as meninas bonecas e coisas a fazer com a casa e para os meninos monstros e as "coisas perigosas". Assim eles são educados da forma que a sociedade quer, é então comum ouvir que um determinado trabalho como pedreiro, arquiteto et etc., é associado aos homens porque ele está ligado à força física, e alguns empregos estão ligados às mulheres, pois ele é considerado como frágil, como cabeleireiro, empregada et etc. (LAUREN).

Já no início do seu texto, Lauren incita à reflexão. Ela traz exemplos da Atividade V (cf. seção 4.1.6.1) sobre a construção do gênero. Ao abordar a diferença dos brinquedos recebidos por meninos e meninas, e as possíveis consequências em suas vidas profissionais, ela demonstra perceber a influência da sociedade na formação dos gêneros desde a infância. 
Em outras palavras, ela parece entender que muitas das nossas escolhas profissionais são incentivadas já na infância por meio dos brinquedos que recebemos, tendo em vista o que eles representam na fomação identitária de meninos e meninas.

Alexandre Agrigento destaca as limitações impostas pelos padrões de gênero:

Imagem 15 - "O problema do gênero começa na sociedade, onde os arquétipos do gênero masculino e feminino nasceram” (ALEXANDRE AGRIGENTO).

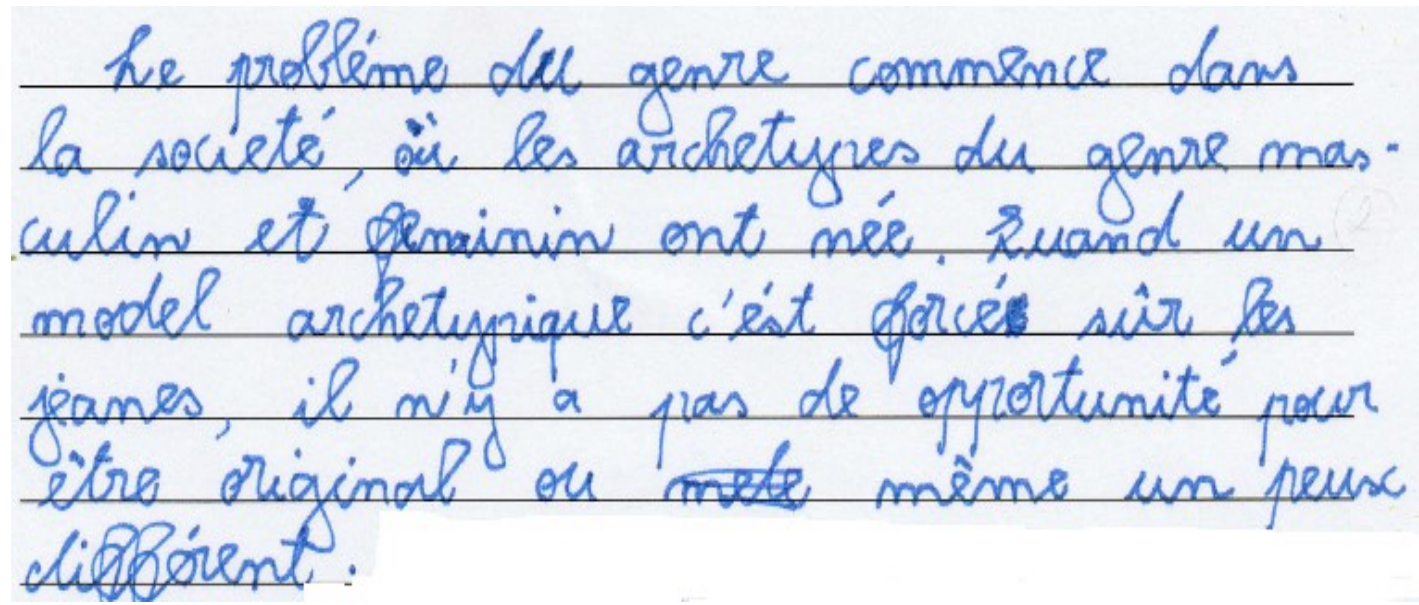

Fonte: Produção Escrita I

Tradução: O problema do gênero começa na sociedade, onde os arquétipos do gênero masculino e feminino nasceram. Quando um modelo arquétipo é forçado sobre os jovens, não há a oportunidade de ser original ou mesmo um pouco diferente (ALEXANDRE AGRIGENTO).

No seu texto, Alexandre Agrigento demonstra entender os modelos de gênero como socialmente construídos e o poder que eles ganham na sociedade para impor comportamentos a homens e mulheres, impedindo-as/os, muitas vezes, de serem originais ou diferentes. Tais modelos levam mulheres e homens a exercer determinadas atividades na sociedade, como destaca o participante Manoca:

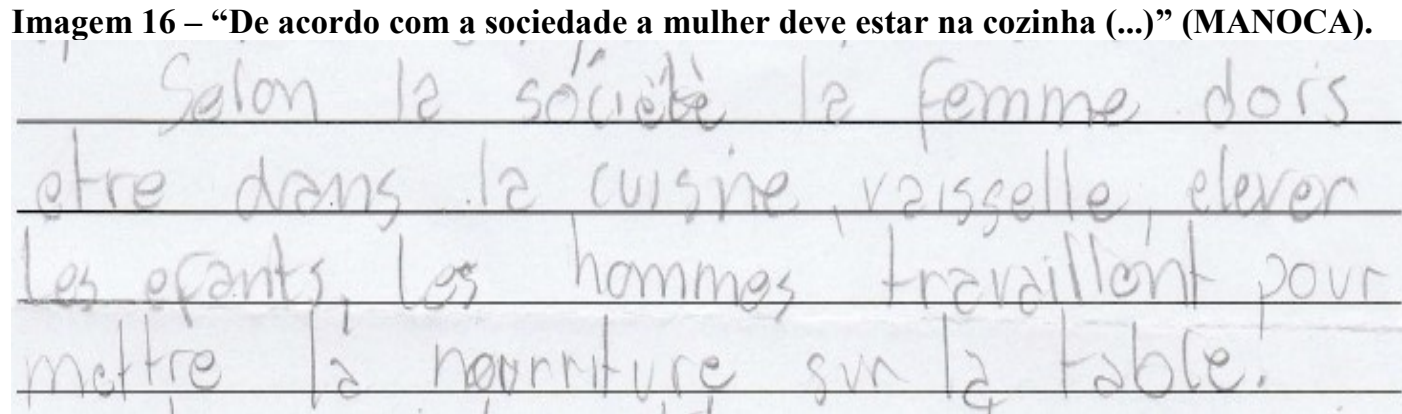

Fonte: Produção Escrita I 
Tradução: De acordo com a sociedade a mulher deve estar na cozinha, [lavar] louça, cuidar dos filhos, os homens trabalham para colocar a comida na mesa. (MANOCA).

Manoca traz, na imagem 16, algumas funções atribuídas a homens e mulheres na sociedade. Contudo, no texto integral da sua produção, ele não chega a abordar as possíveis origens dessas práticas, o porquê de elas existirem a fim de sustentar suas afirmações. Ele parece ter se servido aqui de discursos cristalizados da sociedade sem ter refletido sobre eles.

Buscando uma possível solução para as limitações impostas pelo padrão de gênero, a participante Lauren sugere dar voz às crianças para que possam opinar sobre seus brinquedos ou a maneira como gostariam de se vestir:

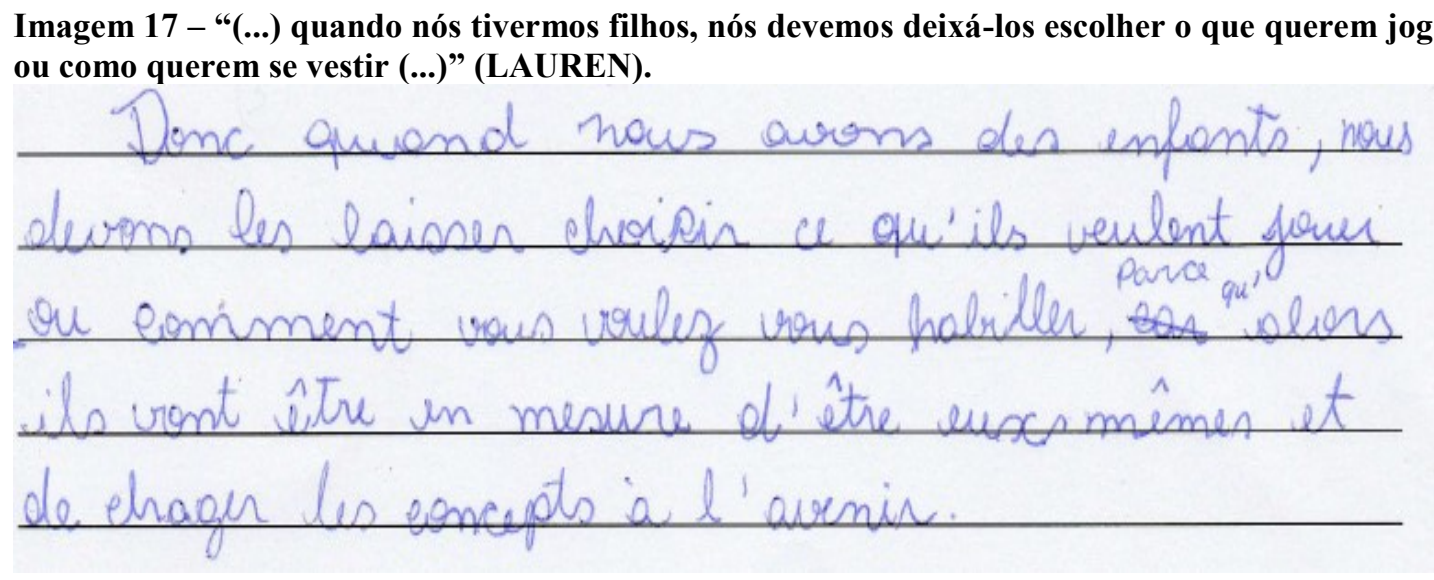

Fonte: Produção Escrita I

Tradução: Então quando nós temos filhos, nós devemos deixá-los escolher o que eles querem jogar ou como vocês querem se vestir porque assim eles vão ser eles mesmos e vão poder mudar os conceitos no futuro (LAUREN).

Lauren parece entender a escolha das crianças como uma maneira de ir contra os modelos de gênero impostos pela sociedade, como uma possibilidade para que a criança manifeste seus desejos e exponha suas percepções de como se vê inserida no mundo. Para Lauren, isso pode levar a sociedade a mudar tais padrões.

Seguindo nessa mesma direção, Roberta recorre à necessidade de se adaptar ao mundo moderno, levando em conta as novas formas de viver as identidades sociais e a importância de conscientizar a nova geração para um mundo melhor. 


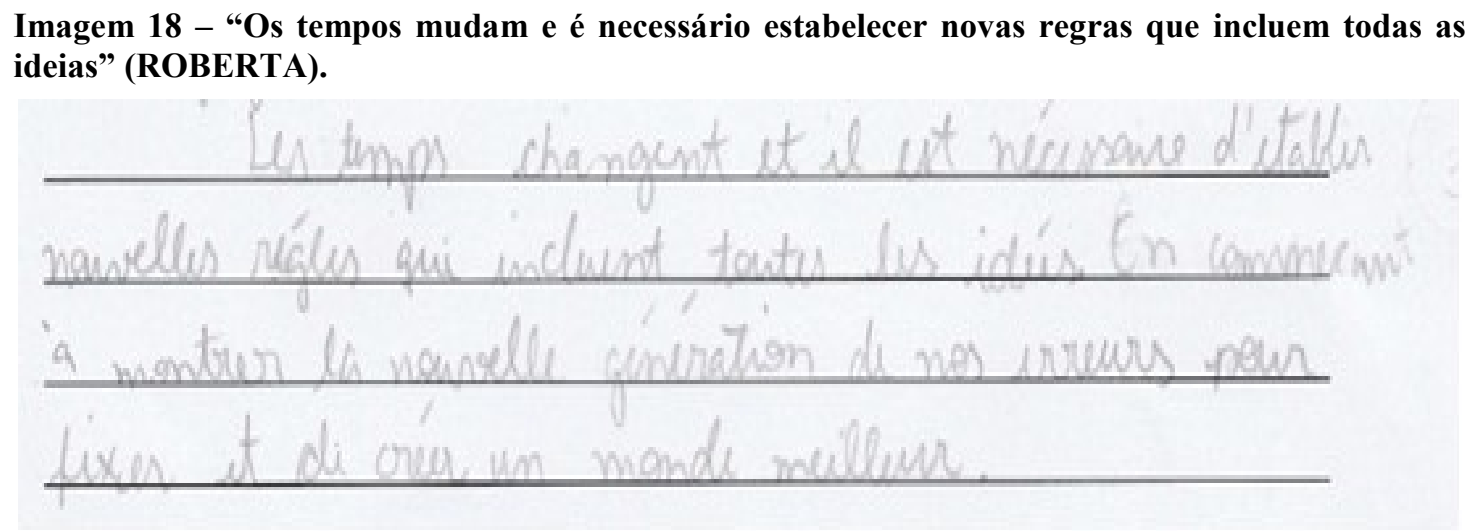

Fonte: Produção Escrita I

Tradução: Os tempos mudam e é necessário estabelecer novas regras que incluem todas as ideias. Começando a mostrar à nova geração nossos erros para fixar e criar um mundo melhor (ROBERTA).

Nesse sentido, é preciso desconstruir as oposições binárias: masculino e feminino na sociedade (SCOTT, 1995). A autora observa que é frequente, nas relações sociais, a dicotomia polarizada dos gêneros. Em outras palavras, é relevante perceber que os gêneros não são opostos, eles se interseccionam, havendo, portanto, diferentes formas de vivê-los.

Outra maneira encontrada pelas/os alunas/os de abordar o tema foi ressaltando a importância da igualdade feminina. Cléo acredita que devemos lutar para reverter esse quadro, ressaltando a relevância da luta feminista, bem como daqueles que se encontram excluídos da sociedade, na construção de uma sociedade mais justa para todas/os:

Imagem 19 - “(...) a luta por igualdade para todas as mulheres é importante (...)” (CLÉO).

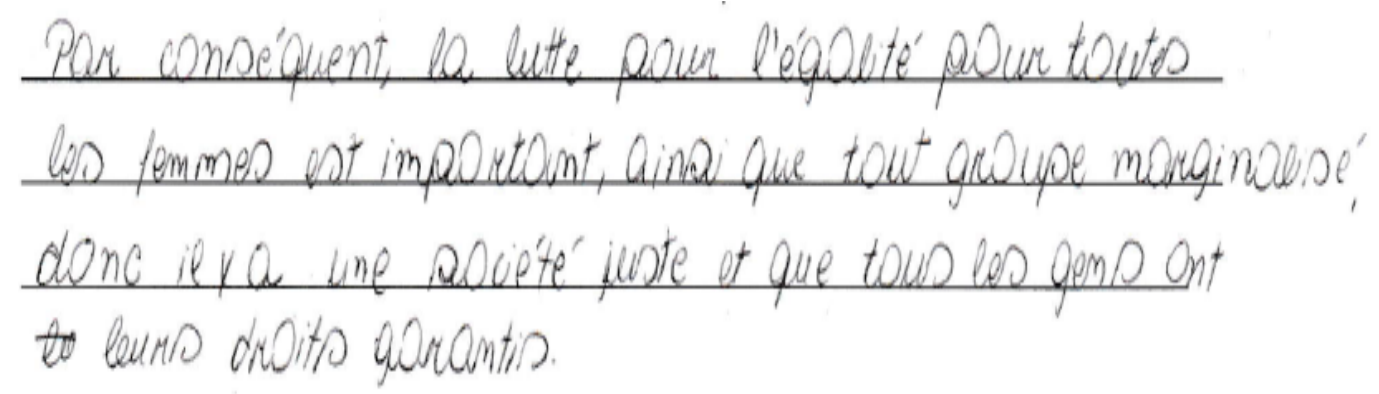

Fonte: Produção Escrita I

Tradução: Consequentemente, a luta pela igualdade para todas as mulheres é importante, assim como todo grupo marginalizado, então tem uma sociedade justa em que todas as pessoas têm seus direitos garantidos (CLÉO).

Tendo em vista os excertos discutidos nesta seção, de maneira geral, as/os alunas/os demonstraram ter refletido sobre as origens e as consequências do padrão de gênero na sociedade, trazendo ainda possíveis ideias para ir além desses arquétipos. Elas/es buscaram 
exemplos para seus argumentos não apenas nas discussões em sala de aula, como também fora dela, demonstrando suas agências na construção dos discursos.

Na seção a seguir, faço a discussão dos dados gerados na segunda produção escrita.

\subsubsection{Produção Escrita II}

A segunda produção escrita foi solicitada durante as atividades sobre gênero e raça/etnia no dia 07/06/16. Assim, busquei ter acesso à maneira como as/os participantes percebiam a dinâmica dessas identidades em sala de aula, verificando, mais uma vez, os desdobramentos do trabalho com o LC na maneira como elas/es compreendem a realidade. Apenas as/os alunas Lara e Washington não me entregaram a Produção Escrita II.

Em seu texto, Alexandre Agrigento questiona o mito da democracia racial na sociedade brasileira, que pressupõe que brancas/os e negras/os convivam em paz sem conflitos raciais e econômicos (CRUZ; RODRIGUES; BARBOSA, 2011; FERREIRA, 2006). $\mathrm{Na}$ verdade essa teoria encobre os conflitos sociais, negando o acesso das/os negras/os aos bens materiais e simbólicos (BOURDIEU, 1994). Como base nisso, Alexandre Agrigento questiona onde estaria a integração entre as raças no Brasil, uma vez que brancas/os e negras/os não ocupam os mesmos espaços na sociedade:

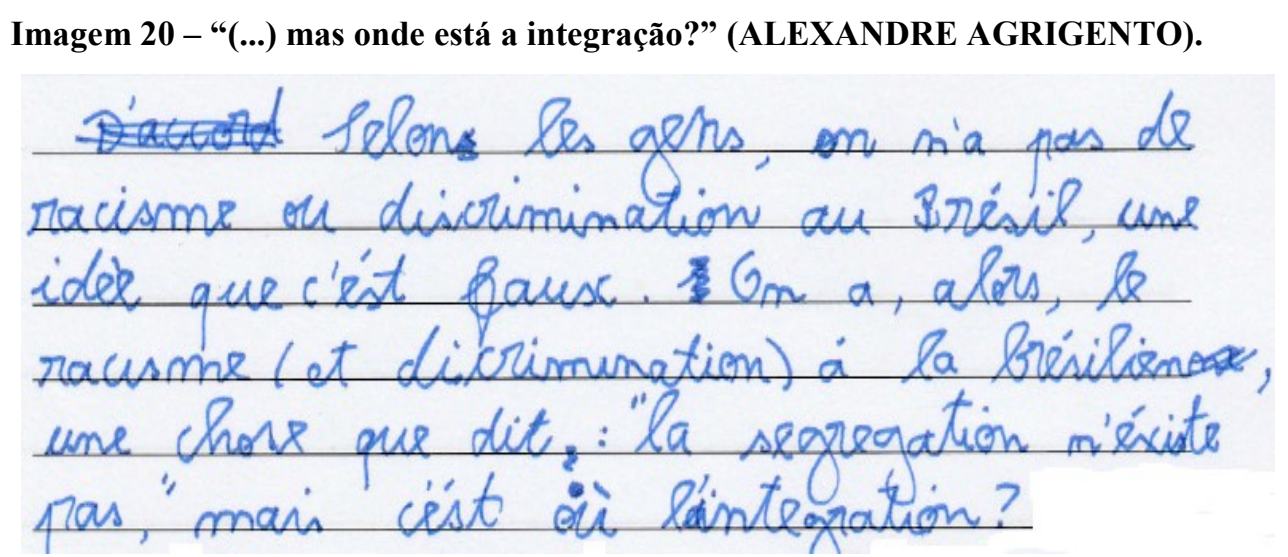

Fonte: Produção Escrita II

Tradução: Para as pessoas, não existe racismo ou discriminação no Brasil, uma ideia que é falsa. Nós temos, então, o racismo (e discriminação) à brasileira, uma coisa que diz: "a segregação não existe", mas onde está a integração? (ALEXANDRE AGRIGENTO).

Para Manoca, as desigualdades entre mulheres brancas e negras decorrem do período da escravidão, no qual as mulheres negras ocupavam postos inferiores às mulheres brancas: 
Imagem 21 - “(...) a origem da desigualdade no Brasil vem do passado (...)” (MANOCA).

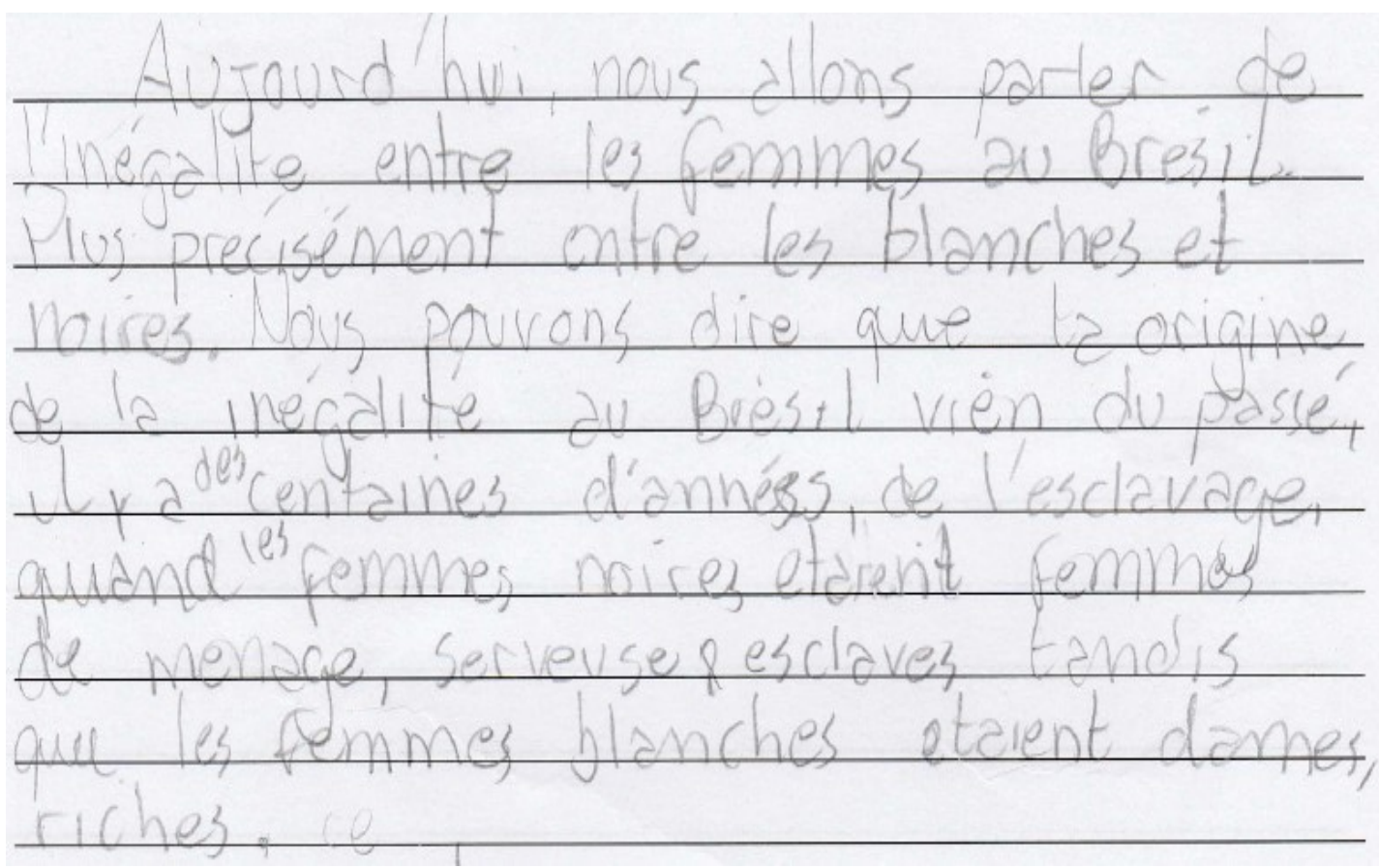

Fonte: Produção Escrita II

Tradução: Hoje, nós vamos falar da desigualdade entre as mulheres no Brasil. Mais precisamente entre as brancas e negras. Nós podemos dizer que a origem da desigualdade no Brasil vem do passado, há centenas de anos, da escravidão quando as mulheres negras eram empregadas domésticas, serventes e escravas enquanto as mulheres brancas eram damas ricas. (MANOCA).

Apesar de Manoca se voltar para o passado buscando explicar as desigualdades entre mulheres brancas e negras na sociedade atual, ele não aborda, na versão completa do seu texto, o porquê de a escravidão ter deixado tamanhas desigualdades na sociedade brasileira. Em nenhum momento, ele questiona as relações de poder existentes entre mulheres brancas e negras e a maneira como isso interfere nas oportunidades e nos acessos dessas mulheres aos espaços privilegiados da sociedade. Em outras palavras, ele menciona a escravidão como consequência das desigualdades, mas não chega a desenvolver criticamente os seus desdobramentos nas construções identitárias de mulheres brancas e negras no Brasil.

As/os alunas/os participantes da pesquisa José, Biel e Anna W trazem fatos e dados estatísticos que comprovam a desigualdade e a torna algo visualizável:

Imagem 22 - “(...) as mulheres brancas recebem mais que a mulher negra (...)” (JOSÉ).

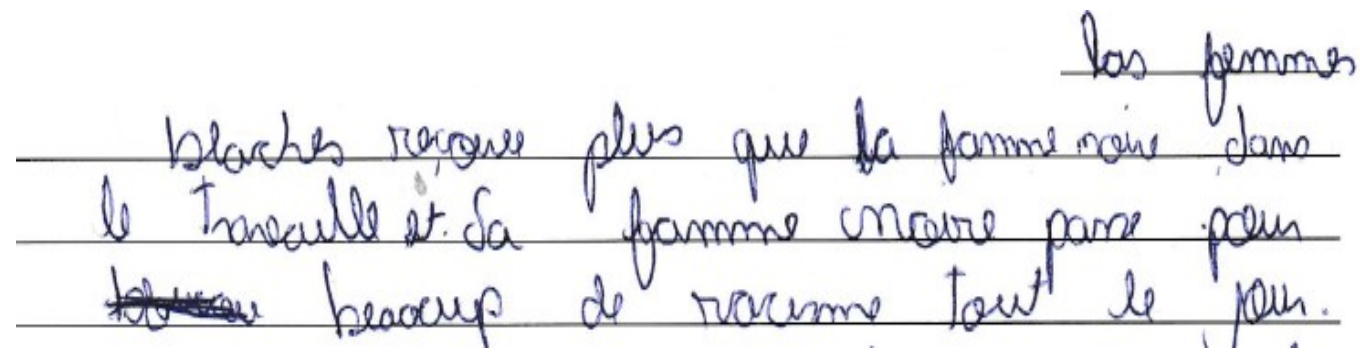


Fonte: Produção Escrita II

Tradução: (...) as mulheres brancas recebem mais que a mulher negra no trabalho e a mulher negra sofre muito racismo todos os dias (JOSÉ).

Imagem 23 - "A população brasileira vive ainda diante de uma grande desigualdade entre negros e brancos" (BIEL).

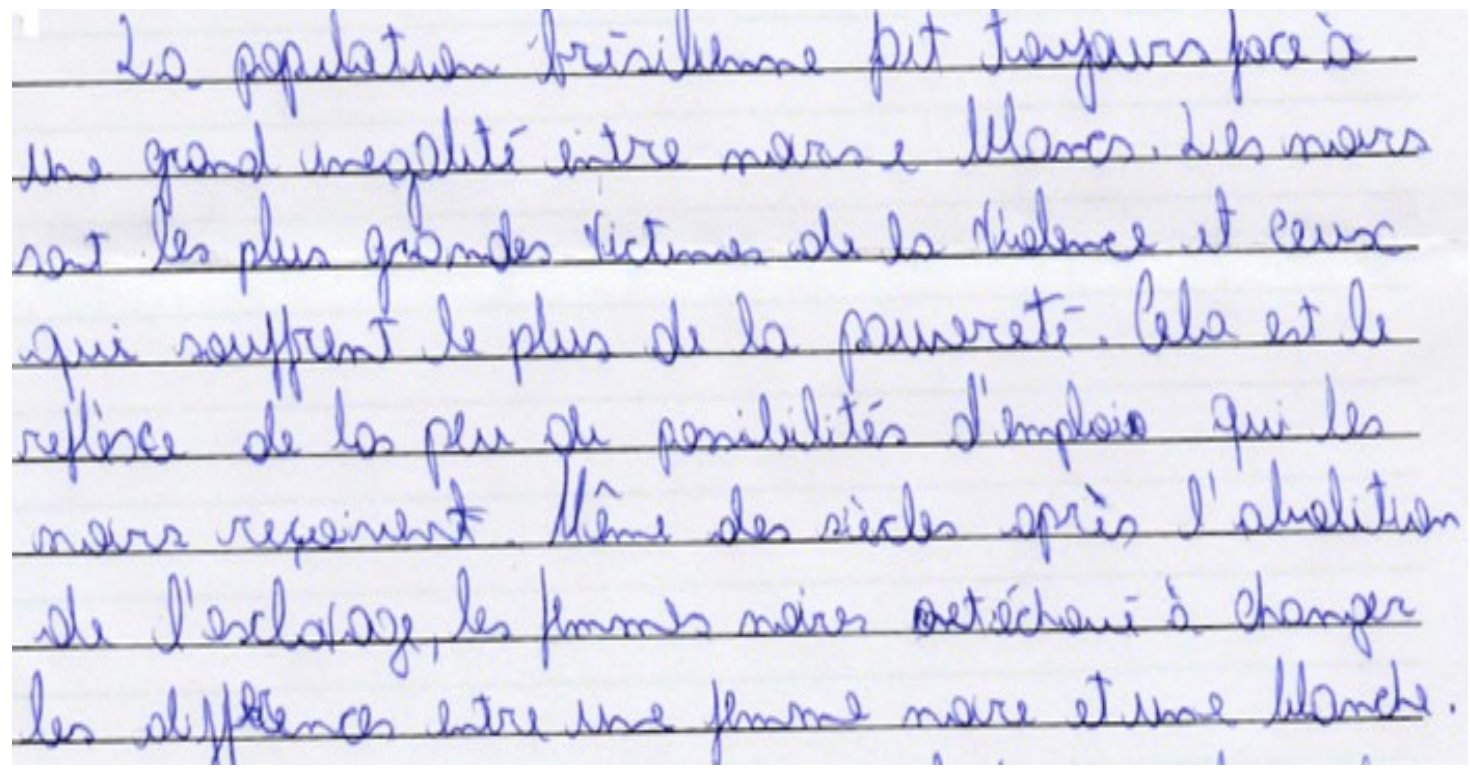

Fonte: Produção Escrita II

Tradução: A população brasileira vive ainda diante de uma grande desigualdade entre negros e brancos. Os negros são as maiores vítimas da violência e os que mais sofrem com a pobreza. Isso é o reflexo das poucas possibilidades de emprego que os negros recebem. Mesmo séculos depois da abolição da escravatura, as mulheres negras fracassaram para mudar as diferenças entre uma mulher negra e branca. (BIEL).

Imagem 24 - "Esta desigualdade tem origem nos tempos da escravidão quando a mulher negra era um objeto sexual" (ROBERVALDO).

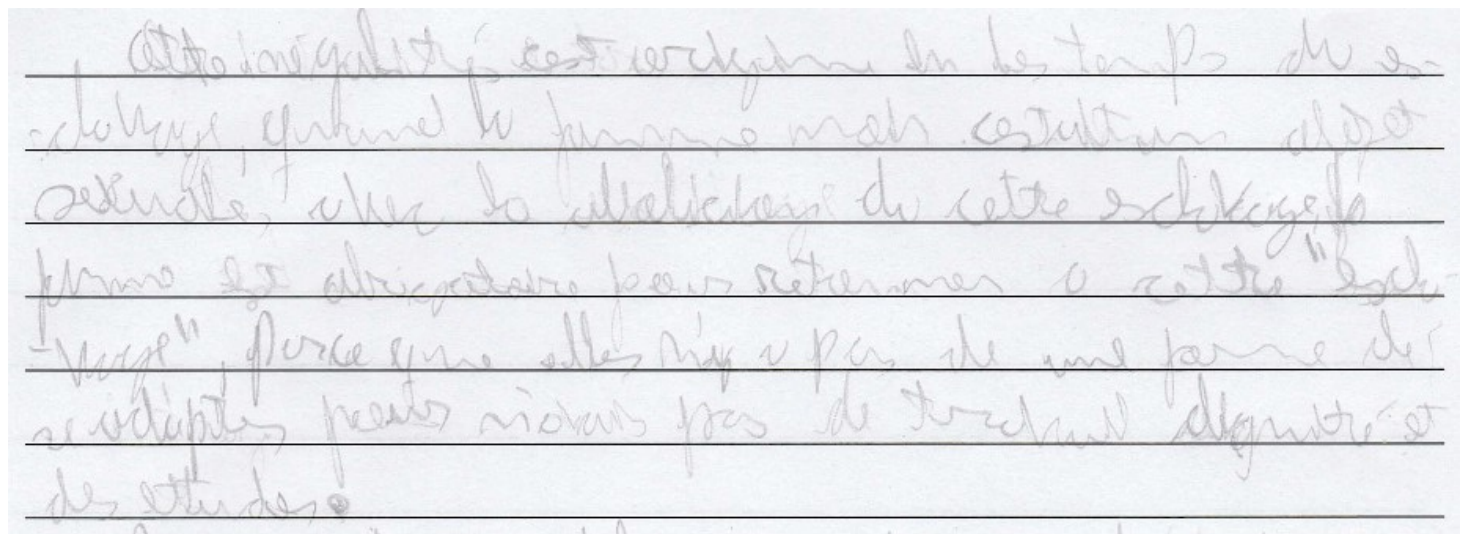

Fonte: Produção Escrita II

Tradução: Esta desigualdade tem origem nos tempos da escravidão quando a mulher negra era um objeto sexual, com a abolição da escravatura a mulher é obrigada a retornar a essa "escravidão" porque ela não tem meios de se adaptar, pois não tem trabalho digno e estudos. (ROBERVALDO). 
$\mathrm{Na}$ imagem 22, José menciona a diferença de salário entre mulheres brancas e negras, mas, assim como Manoca na imagem 21, ele não discute o porquê dessas diferenças. Da mesma forma, no seu texto, ele apenas cita a escravidão como consequência das desigualdades, mas não problematiza os seus efeitos e as relações de poder existentes entre essas mulheres. Percebo que tanto José quanto Manoca destacaram em seus textos pontos das discussões em sala, mas não trouxeram uma reflexão crítica a esse respeito. Nesse sentido, acredito que a própria idade do participante José - 14 anos - tenha tido influência no desenvolvimento de um tema tão delicado, pois a sua maturidade interfere na maneira como ele vê e entende as situações.

O participante Biel, por sua vez, demonstra reconhecer as desigualdades entre brancas/os e negras/os na sociedade, destacando, inclusive, a violência e a pobreza vivenciadas pelas/os negras/os. Porém, ao mesmo tempo em que ele ressalta as diferentes oportunidades de trabalho dadas às/aos negras/os, ele parece entender a diferenças entre mulheres brancas e negras como fracasso e não como consequência da falta de oportunidades para que as mulheres negras tivessem espaço para deixar suas vozes serem ouvidas.

O participante Robervaldo demonstra perceber as diferentes oportunidades dadas a mulheres brancas e negras. Para ele, elas são consequências da escravidão, que não possibilitou que essas mulheres pudessem exercer um trabalho de maior prestígio social devido à falta de estudos e acesso aos espaços valorizados na sociedade. Em seu texto, ele menciona alguns momentos das interações em sala, mas não chega a desenvolver seus argumentos. Ou seja, parece que as discussões em sala possibilitaram novas ressignificações na maneira como ele percebe as identidades de gênero e raça/etnia, algo que pode ser mais aprofundado com outras reflexões e problematizações.

Ainda com relação às desigualdades, Anna W destaca a pouca representação de mulheres negras nas revistas de moda, que tendem a privilegiar a mulher branca:

Imagem 25 - “(...) as capas estão frequentemente cheias de mulheres brancas (...)" (ANNA W).

Actuelemente les uneacaliós entre leommes beanche

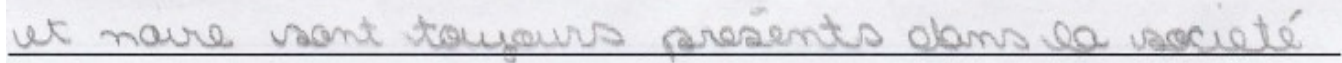

bresiliemme. On paut gleserven ca dans le moganines

de mode. Dams sers mogousunes, les equrvertaure

wont survamt rompor ause dos fommon blanche et

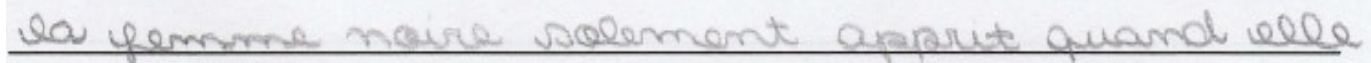




\section{Fonte: Produção Escrita II}

Tradução: Atualmente, as desigualdades entre as mulheres brancas e negras ainda estão presentes na sociedade brasileira. Podemos ver isso nas revistas de moda. Nessas revistas, as capas estão frequentemente cheias de mulheres brancas e a mulher negra somente aparece quando ela é muito famosa ou quando ela fala de preconceito. (ANNA W).

Em seu relato, a participante Anna W retoma o tema da Atividade X (cf. seção 4.1.11.1) e observa que a primazia da branquitude ainda permanece nas capas de revista de moda, que têm como referência os padrões eurocêntricos, distanciando-se da realidade encontrada no Brasil. Na aula na qual desenvolvi a referida atividade, Anna $\mathrm{W}$ foi a que mais se posicionou e foi a primeira a identificar o padrão da mulher branca estampado nas revistas. Isso nos mostra que, de alguma forma, as discussões em sala podem proporcionar momentos de reflexão sobre os eventos sociais e contribuir para que as/os alunas/os reorganizem seus discursos e expressem seus pontos de vistas quando necessário.

Analisando ainda a discriminação entre brancas/os e negras/os na sociedade, a estudante Lenor Estevão destaca o peso da supremacia branca e masculina:

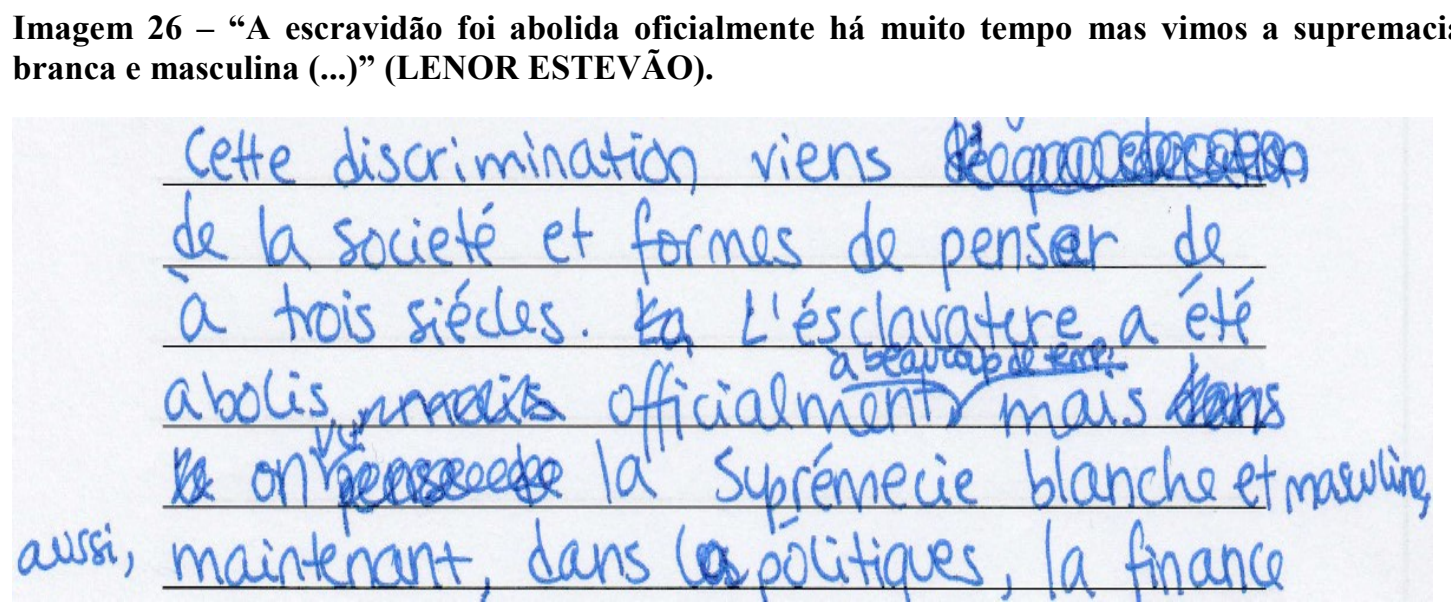

Fonte: Produção Escrita II

Tradução: Essa discriminação vem da sociedade e formas de pensar de três séculos atrás. A escravidão foi abolida oficialmente há muito tempo mas vimos a supremacia branca e masculina, também, agora na política, nas finanças (...) (LENOR ESTEVÃO).

Lenor Estevão ressalta a prevalência de homens brancos na política e nas finanças. Para ela, tal situação advém do passado, mas aqui é possível questionar por que a origem dessa prática se encontraria exatamente há três séculos? Não há dúvidas de que a supremacia branca, que prevê a noção de inferioridade da/o negra/o, ainda se encontra introjetada no nosso imaginário social (HOOKS, 2010; TELLES, 2003; GOMES, 1996), bem como a 
supremacia masculina, que naturaliza a superioridade do homem em relação à mulher (FERREIRA; FERREIRA, 2011). Em seu texto, Lenor Estevão demonstra perceber as desigualdades nas relações de poder entre homens e mulheres, brancas/os e negras/os. Como uma possível solução para tal desigualdade, a participante Cléo aponta a importância da representação da mulher negra nos meios de comunicação:

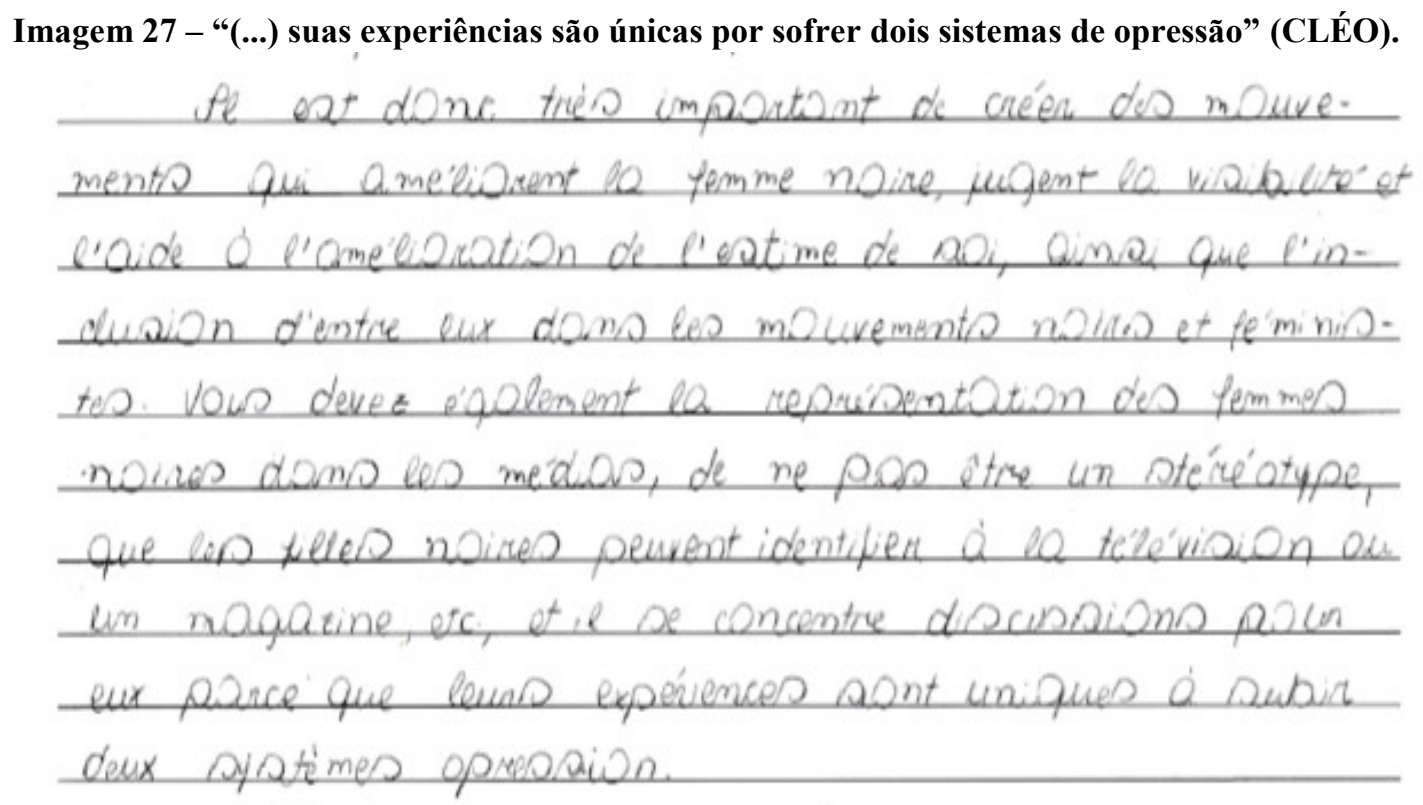

Fonte: Produção Escrita II

Tradução: É muito importante criar movimentos que melhorem [a condição] da mulher negra, pensando na visibilidade e a ajude na melhora da estima de si, assim como sua inclusão nos movimentos negros e feministas. Você deve igualmente [favorecer] a representação das mulheres negras na mídia, para não ter um estereótipo, que as mulheres negras possam se identificar na televisão ou nas revistas, etc. e que fortaleçam discussões para elas porque suas experiências são únicas por sofrer dois sistemas [de] opressão (CLÉO).

Cléo destaca, em seu texto, a importância dos movimentos sociais que se voltam para as opressões sofridas pelas mulheres negras. Ela demonstra reconhecer as relações assimétricas de poder entre mulheres brancas e negras ao enfatizar a maneira como as intersecções de gênero e raça/etnia influenciam nas trajetórias seguidas por essas mulheres no Brasil. Para Cléo, as particularidades vividas pelas mulheres negras devem ser levadas em consideração por esses movimentos para favorecer seu empoderamento na luta por uma representatividade social capaz de romper com estereótipos.

Para tanto, as/os participantes Johnson e Lenor Estevão destacam a importância da conscientização, não apenas na escola, como também em casa e nos meios de comunicação em prol de uma sociedade mais igualitária: 
Imagem 28 - "A vida tem soluções possíveis para o racismo, preconceito e as desigualdades: é a educação (....)" (JOHNSON).

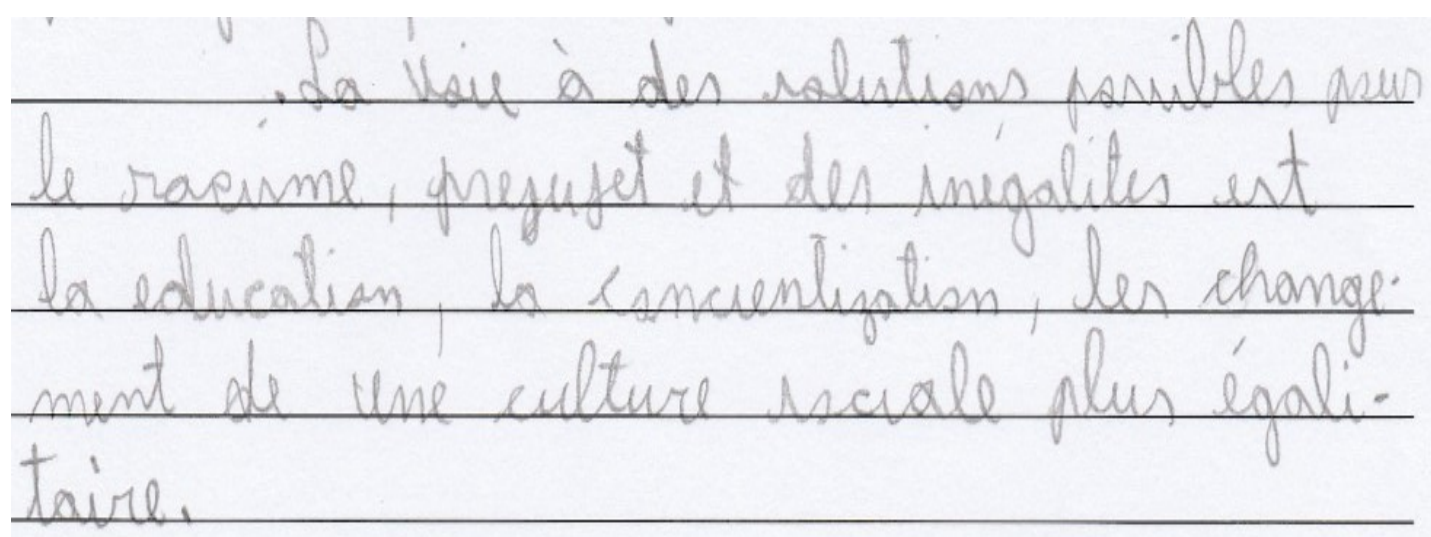

Fonte: Produção Escrita II

Tradução: A vida tem soluções possíveis para o racismo, preconceito e desigualdades é a educação, a conscientização, as mudanças de uma cultura social mais igualitária (JOHNSON).

Imagem 29 - “(...) a única forma de mudar as desigualdades entre mulheres e homens e brancos e negros é a educação (...)" (LENOR ESTEVÃO).

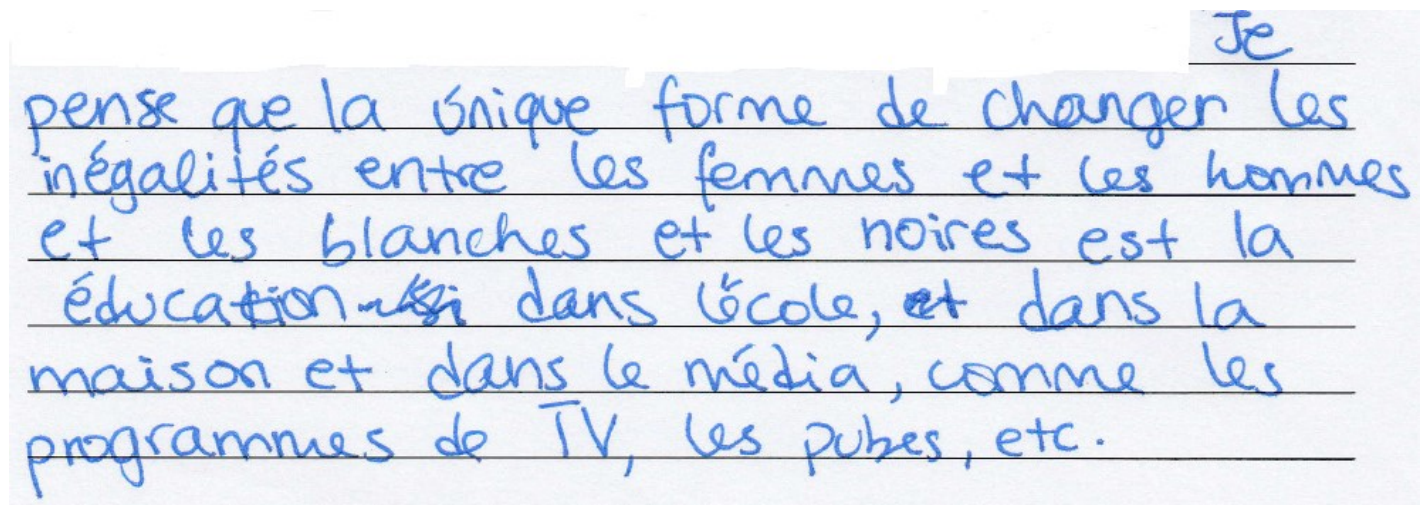

Fonte: Produção Escrita II

Tradução: Eu acho que a única forma de mudar as desigualdades entre mulheres e homens e brancos e negros é a educação na escola, em casa e na mídia, como os programas de TV, as propagandas, etc. (LENOR ESTEVÃO).

Johnson e Lenor Estevão parecem ver a escola, a família e a mídia como importantes espaços para repensar as situações da realidade, ou seja, como instituições reconhecidas por idealizar e propagar discursos construtores de identidades. Suas ideias vão ao encontro do previsto pelos documentos educacionais oficiais (BRASIL, 1998, 2006, 2003, 2004), que reforçam o trabalho com LC, bem como das relações étnico-raciais em sala de aula com vistas a uma formação crítica e cidadã, capacitando a/o aluna/o a agir na sociedade em prol da diversidade e da empatia com as múltiplas formas de viver as identidades sociais no mundo pós-moderno. Nesse sentido, Johnson e Lenor Estevão demonstram ver os momentos de discussão em sala como produção de mudança, uma possível busca por soluções. 
Como foi possível observar, as/os alunas/os destacaram as consequências da escravidão no país, buscando, no passado, possíveis explicações para compreender a situação da sociedade atual, como ressalta Pennycook (2001). Algumas/uns delas/es apenas mencionaram a escravidão, outras/os abordaram seus desdobramentos, destacando as desigualdades e as relações de poder entre as identidades. Observei que as problematizações em sala trouxeram influências para seus textos, levando-as/os a reorganizarem seus discursos para expessarem suas opiniões. Dessa forma, algumas/uns delas/es demonstram perceber que a desigualdade não é natural, mas que foi construída e reforçada ao longo dos anos devido às diferenças nas oportunidades dadas a brancas/os e negras/os no Brasil.

Destaco aqui as produções escritas dos participantes Biel e Robervaldo que, apesar de não terem se posicicionado de maneira ativa nas interações como as/os demais colegas da rede privada, pareceram refletir sobre os discursos presentes nesse ambiente de ensino. Em seus textos, eles puderam se expressar na língua francesa e se fazerem "ouvir", trazendo momentos das interações em sala, o que pode levá-los a outras reflexões e ações futuras.

Na seção a seguir, faço a discussão dos dados gerados pelo questionário final.

\subsection{Discussão do questionário final}

No final do semestre, entreguei o questionário final (cf. apêndice 6). O questionário continha duas perguntas: "Como você descreveria as aulas de francês desse semestre?" e "O que ficou dessas aulas? O que você vai levar para sua vida?". O objetivo era ter a opinião das/os alunas/os a respeito das aulas do semestre como um todo. Apenas um aluno não respondeu ao questionário por não estar presente nas duas últimas aulas. A aluna Cléo me enviou suas opiniões via e-mail.

De maneira geral, as/os participantes relataram que as aulas foram diferentes das que tinham tido, por trazer questões sociais para serem abordadas na aula de língua francesa. É o que pode ser visto nos comentários a seguir:

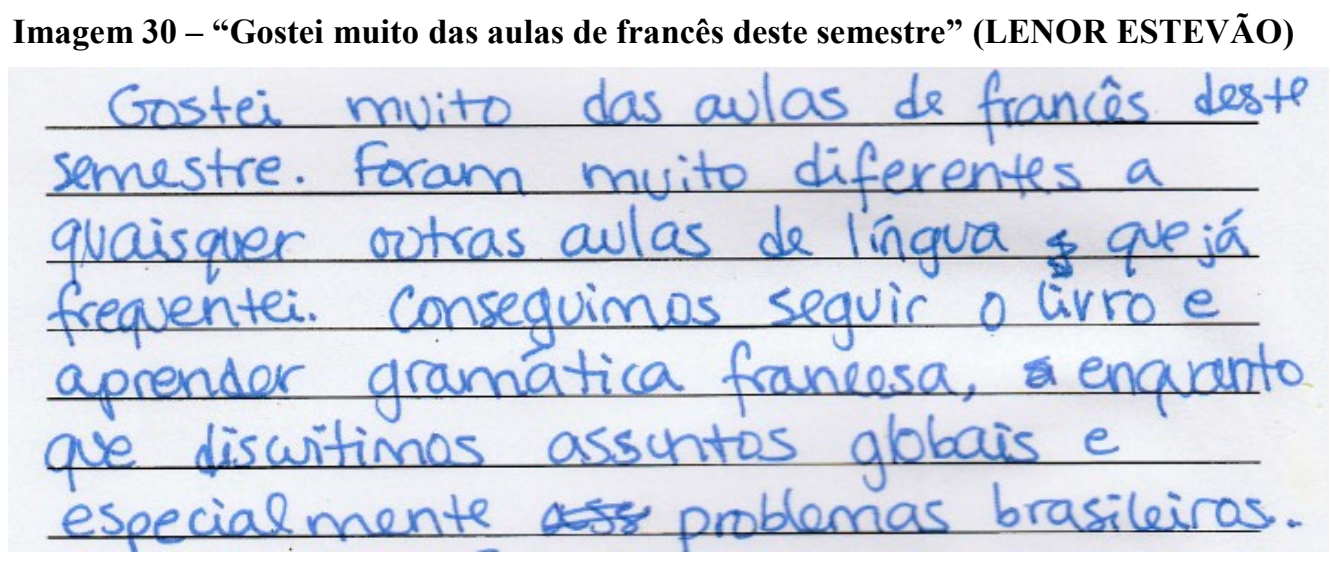


Fonte: Questionário Final

Imagem 31 - “(...) achei interessante como a professora embutiu as discussões com o francês" (ROBERVALDO)

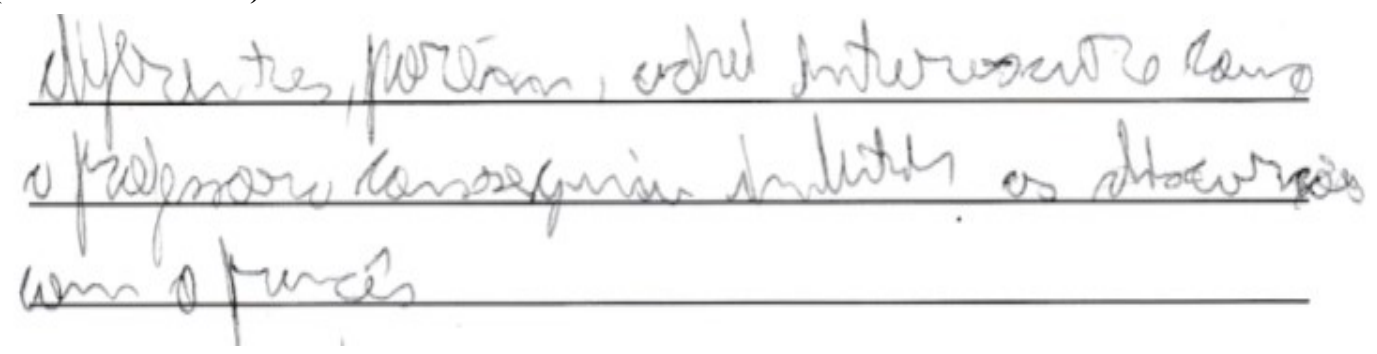

Fonte: Questionário Final

Imagem 32 - “(...) além de estudarmos francês, aprendemos muito sobre como é grande a desigualdade social (...)" (BIEL)

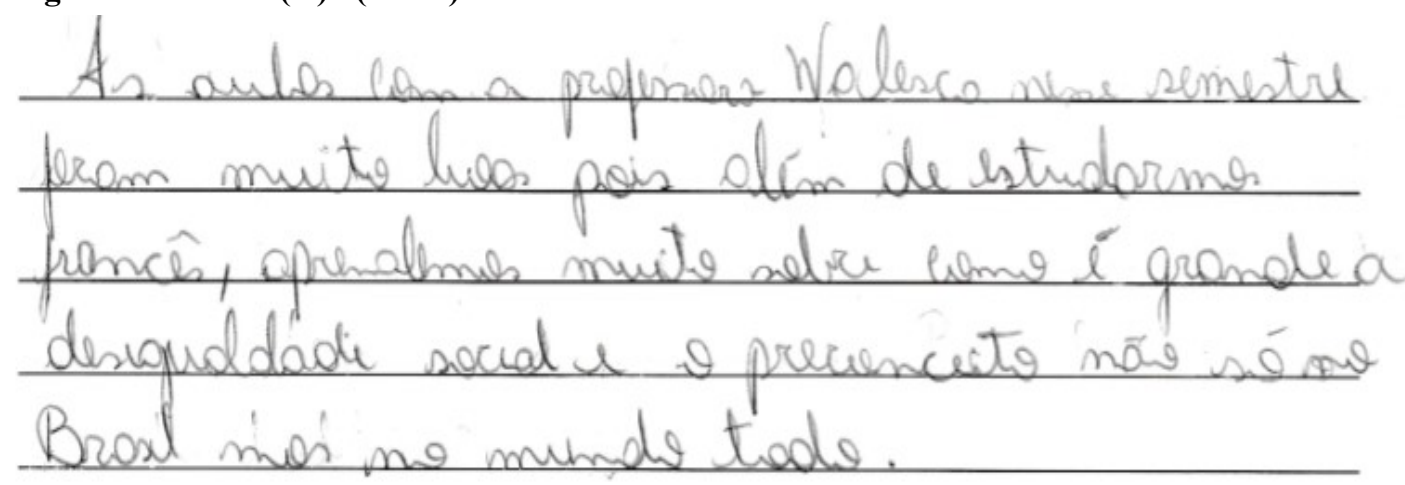

Fonte: Questionário Final

Imagem 33 - "Interessantes para aprender novos conceitos em francês (...)" (ANNA W)

Intereasanter pana apaender solere maves

eanceiton um frances le olvocutur temans

upreaentes una vaciodado

Fonte: Questionário Final

Imagem $34-“(. .$.$) diversas oportunidades de realizar discussões sobre vários temas (...)"$ (JOHNSON) 
Fonte: Questionário Final

Em seus comentários, as/os participantes Lenor Estevão e Robervaldo destacam a diferença das aulas, sobretudo pelas discussões feitas em sala. Contudo, elas/es parecem entender o aprendizado da língua de maneira mecânica, associado ao livro didático e à gramática, sem prever o uso real dessa língua para falar de si mesmas/os e da realidade em que vivem. Ao dizer que "a professora conseguiu embutir as discussões com o francês" e não "em francês", Robervaldo frisa essa diferença contrapondo o francês com as discussões.

O mesmo pode ser visto no comentário de Biel que, apesar de enfatizar o aprendizado sobre situações da realidade, demonstra entender o estudo do francês como algo à parte das discussões. Em outras palavras, as/os alunas/os separam o que é francês - língua - e o que é desigualdade, injustiça, temas críticos. Ao final do semestre, elas/es ainda parecem não ter visto uma integração entre língua e sociedade, como prevê o letramento. É um desafio dessa prática pedagógica. Acredito que essa separação advém do próprio ambiente da sala de aula. Ao longo do semestre, as/os alunas/os ressaltaram que as aulas eram diferentes justamente pelo fato de estarem discutindo questões sociais. Ou seja, elas/es não estão acostumadas/os a aprender língua discutindo essas questões. Isso mostra como as aulas de línguas ainda tendem a ser tradicionais, se voltando para o livro didático, que, em geral, trazem temas neutros e pacificados que não tocam nas estruturas e hierarquias sociais. Temas como sexismo, feminismo, violência doméstica, racismo, homofobia, desigualdade social, dentre outros, ainda não se encontram devidamente inseridos na escola.

Por sua vez, as/os participantes Anna W e Johnson ressaltam a relevância das discussões para a aprendizagem de novos termos, como também para praticar e aperfeiçoar a língua. Em seus comentários, elas/es mesclam as práticas pedagógicas, interligando-as no processo de ensino e aprendizagem do francês. Seguindo o mesmo raciocínio, a estudante Lara menciona a diferença das aulas e destaca que as discussões feitas em francês foram importantes, não apenas para a prática da língua, como também para desenvolver a reflexão crítica das/os alunas/os: 
Imagem 35 - “(...) além de promover a capacidade crítica dos alunos fez com que treinássemos mais a nossa pronúncia” (LARA).

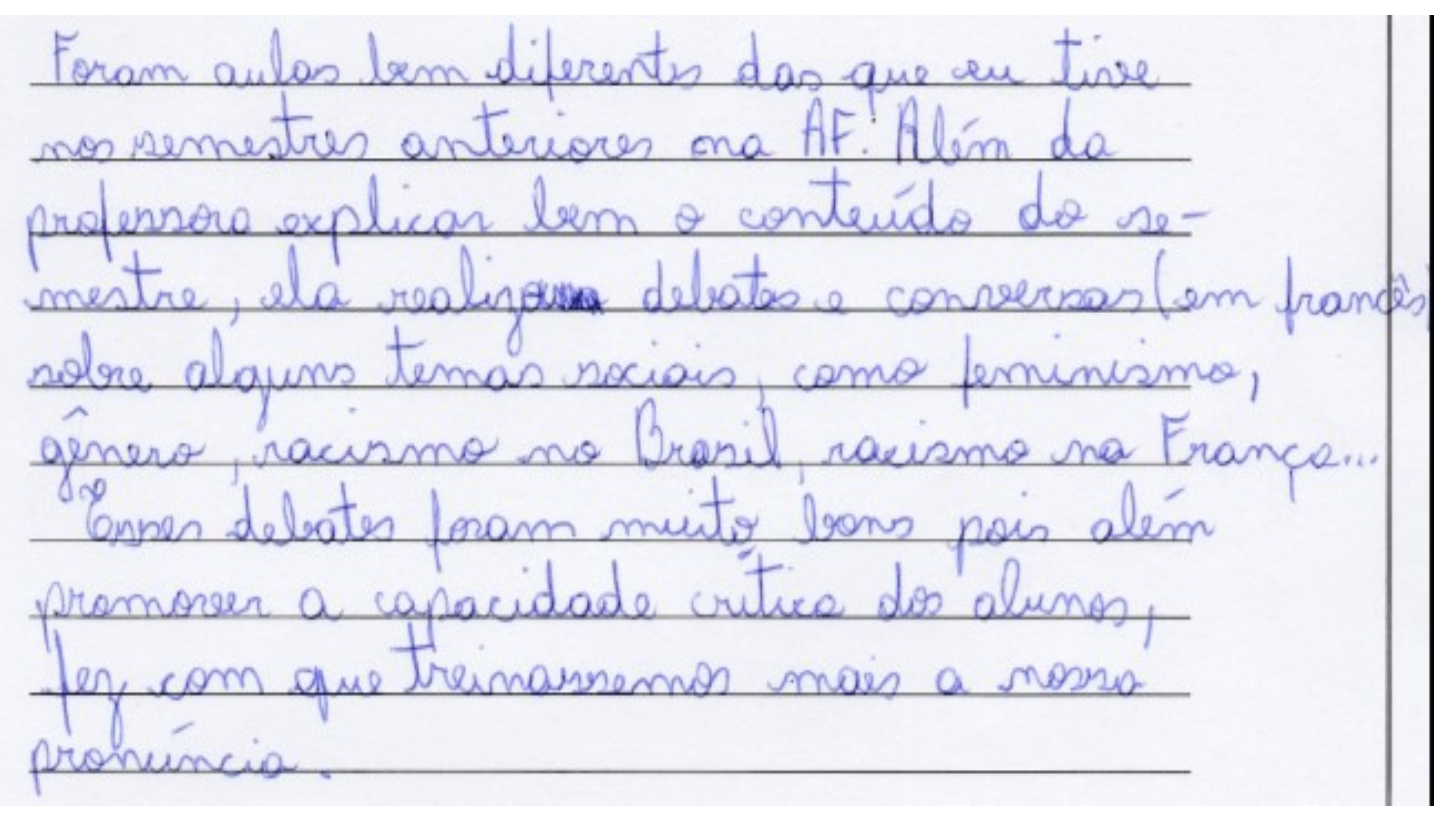

Fonte: Questionário Final

Roberta também aponta a relevância desse ensino na formação crítica para que seja possível analisar os diferentes pontos de vista sobre uma situação e não apenas o que é encontrado nos meios de comunicação em geral. Gomes (2006) lembra que a escola é o espaço da diversidade onde a/o aluna/o tem acesso a diferentes opiniões, costumes e comportamentos e, como educadoras/es, devemos possibilitar que esse momento seja aproveitado para se discutir, democraticamente, a vivência da diversidade na sociedade, possibilitando uma formação cidadã:

Imagem 36 - “(...) Permitiu olhar o tema em outro ponto de vista que é normalmente retratado pela mídia em geral" (ROBERTA)

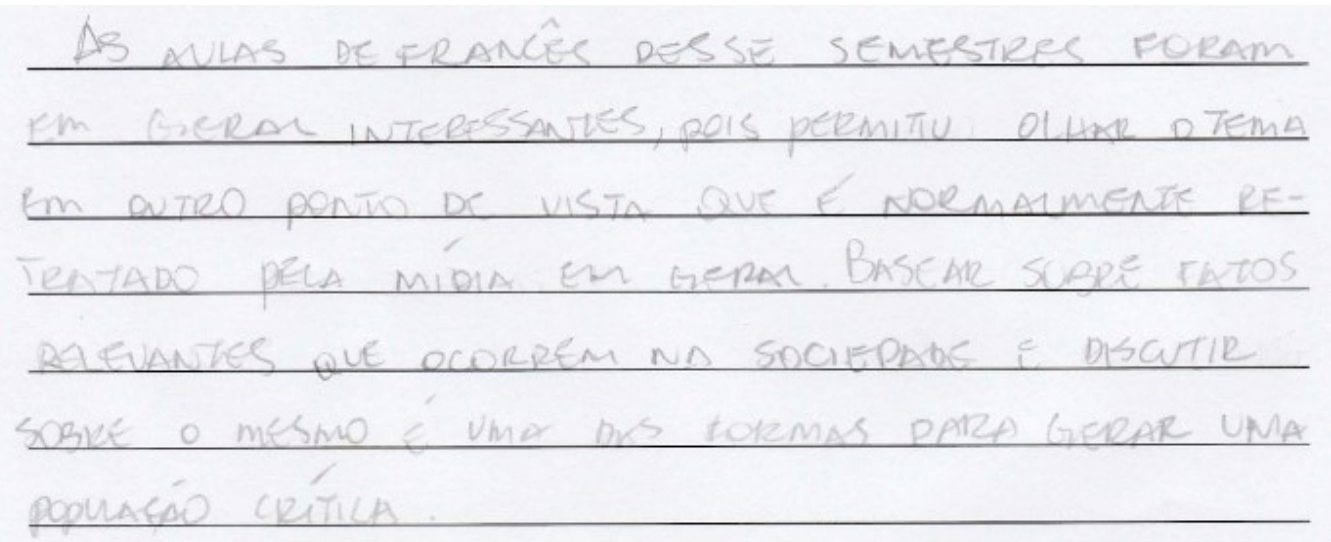

Fonte: Questionário Final 
Washington evidencia que tais temas, que falam de suas vidas, não se encontram devidamente inseridos nas aulas de maneira geral:

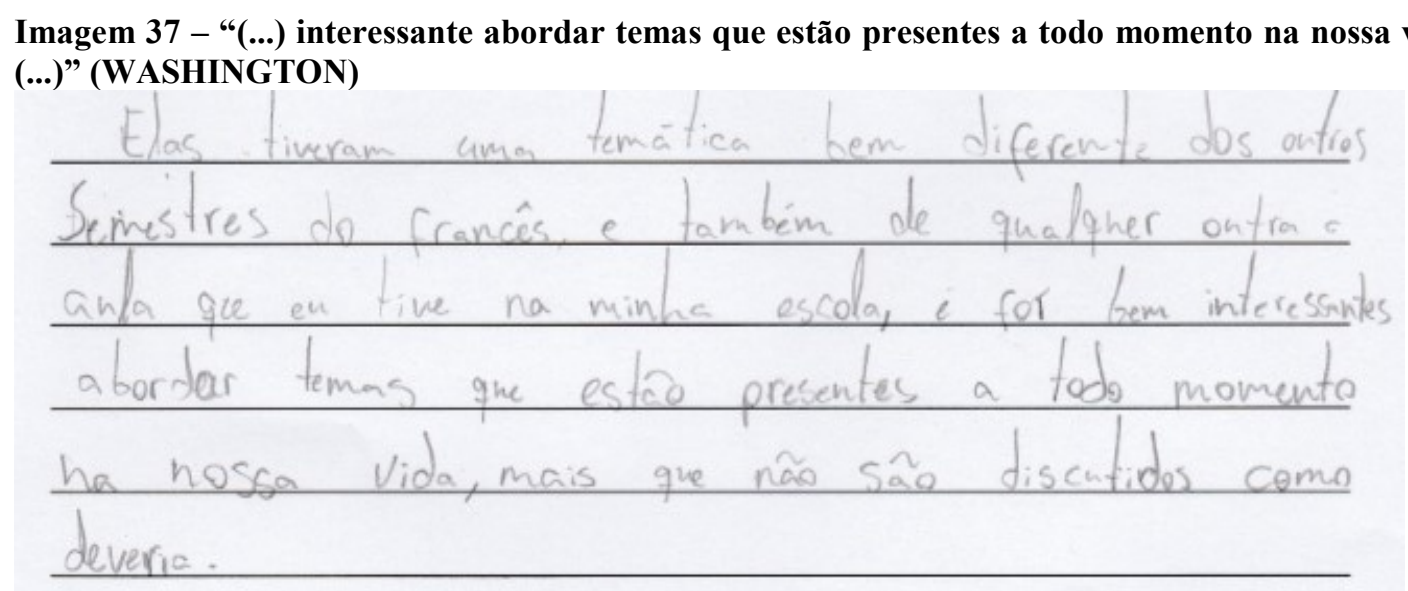

Fonte: Questionário Final

Alexandre Agrigento, por sua vez, relata ter tido dificuldade em se expressar em francês devido ao seu conhecimento da língua:

Imagem 38 - “(...) senti limitado pelas minhas capacidades expressivas em francês (...)" (ALEXANDRE AGRIGENTO)

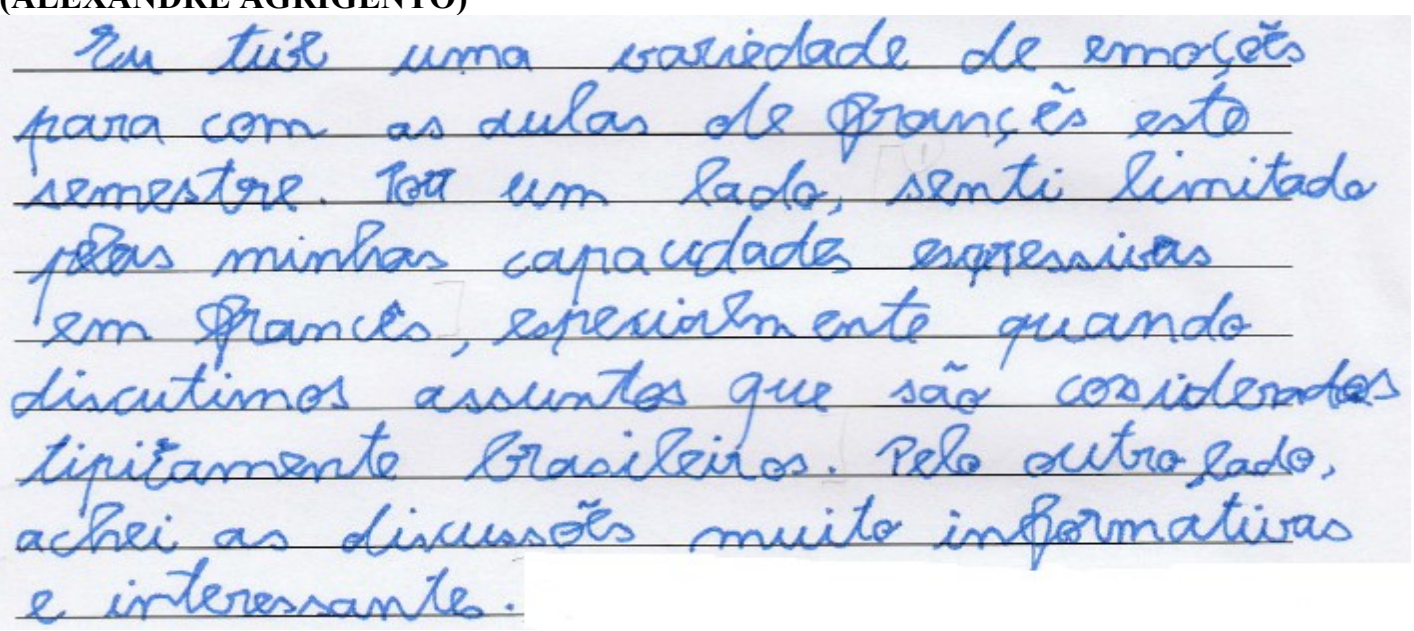

Fonte: Questionário Final

Apesar do seu comentário, é curioso observar que, ao longo do semestre, Alexandre Agrigento foi um dos que mais usou o francês nas aulas. De maneira geral, ele conseguiu expressar suas opiniões, formulando argumentos coerentes na língua adicional. Em seu texto, é possível inferir que sua dificuldade se encontrava, sobretudo, ao discutir temas "tipicamente 
brasileiros". Aqui importa refletir se ele entende as situações analisadas como retratos apenas da sociedade brasileira, não sendo possível encontrar casos semelhantes em outros contextos. Outra questão que surge é: a situação relatada não seria uma questão de identidade? Por ser de nacionalidade portuguesa, caso fossem selecionados exemplos de situações da realidade de Portugal, por exemplo, ele se sentiria mais à vontade para se expressar em francês, ou a limitação permaneceria? Acredito que a língua não seria um limitador em nenhum dos casos, apenas o contexto seria diferente. Contudo, as discussões abrem espaço justamente para que as/os alunas/os possam analisar como as situações estão presentes nas suas próprias realidades ou no seu país, trazendo as especificidades para a reflexão e enriquecendo o debate. Em todo caso, acredito que teria sido interessante trazer situações da realidade portuguesa para que todas/os pudessem se identificar com os temas da mesma maneira.

Em seu relato, o participante Manoca diz ter apreciado a oportunidade de se posicionar e de expor suas opiniões em francês a respeito das desigualdades encontradas na sociedade atual no que tange ao gênero e à raça/etnia, ajudando-o no desenvolvimento pessoal, bem como nas suas capacidades linguístico-discursivas:

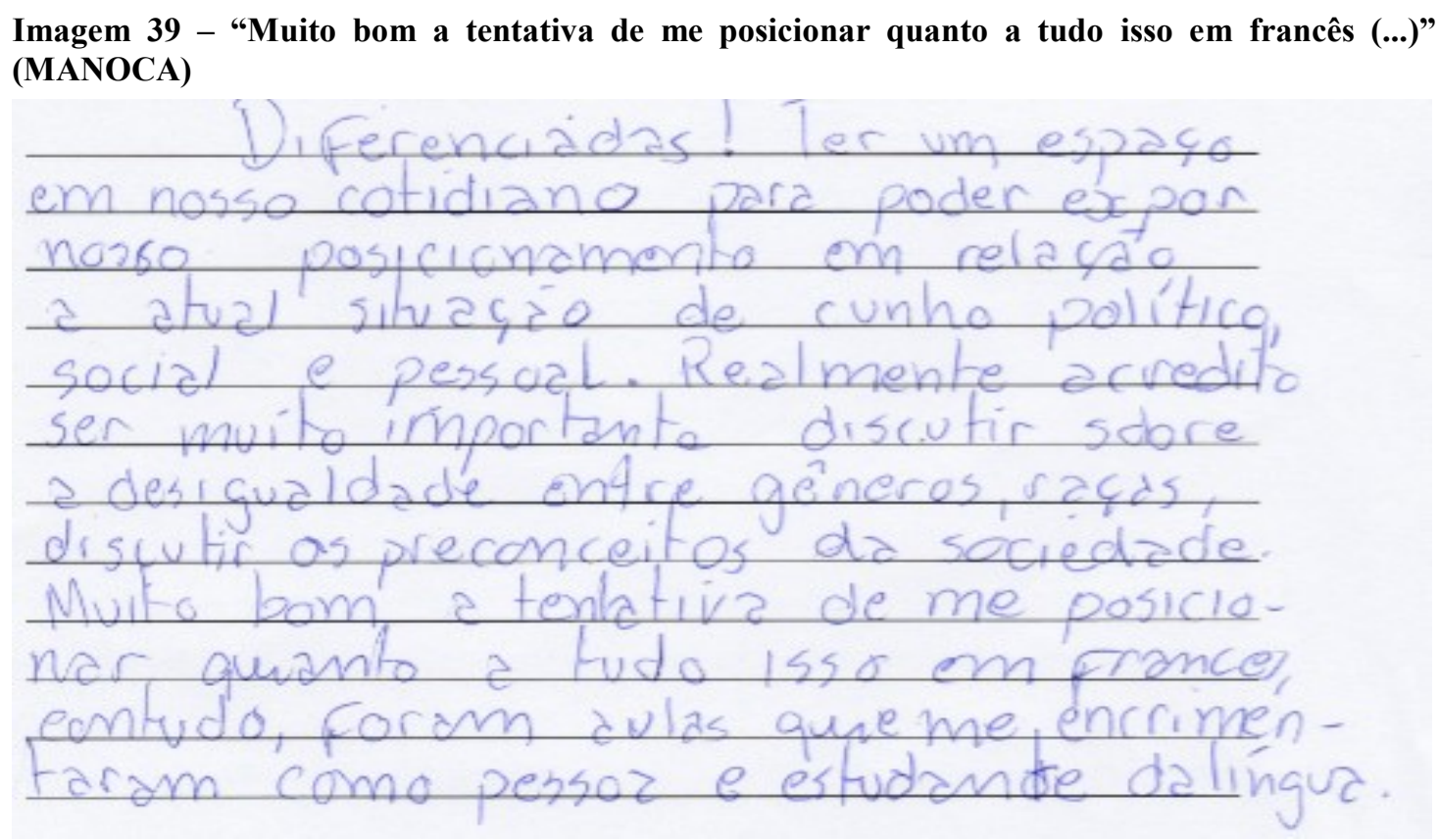

Fonte: Questionário Final

A participante Cléo, por sua vez, destaca a relevância das discussões na percepção das desigualdades presentes em outras culturas, como a cultura francesa, por exemplo, além da 
sua relevância para favorecer a reflexão sobre como os preconceitos podem mudar a depender do país:

\section{Imagem 40 - "Foi de imenso ganho pessoal (...)" (CLÉO)}

Eu descreveria as aulas desse semestre como extremamente educativas e interessantes. A discussão enriqueceu muito o meu intelecto e trouxe novas perspectivas sobre como os preconceitos se manifestam em outra cultura: a francesa. Eu tenho muito interesse nessas questões, mas sempre tive um conhecimento muito focado no Brasil e nos Estados Unidos e as aulas abriram meus olhos para os outros países. Foi de imenso ganho pessoal, por isso foi o melhor semestre de francês, pelo conhecimento adquirido na língua francesa como também pela interculturalidade em temas que afetam a todos, mas que tem suas pequenas diferenças de país para país.

Fonte: Questionário Final

Com relação à segunda questão do questionário: O que ficou dessas aulas? O que você vai levar para sua vida?, Lauren ressaltou a importância de aprender a respeitar o outro, algo que, de maneira geral, não é devidamente salientado nas escolas:

Imagem 41 - “(...) aprender sobre como respeitar o próximo é sempre bom” (LAUREN)

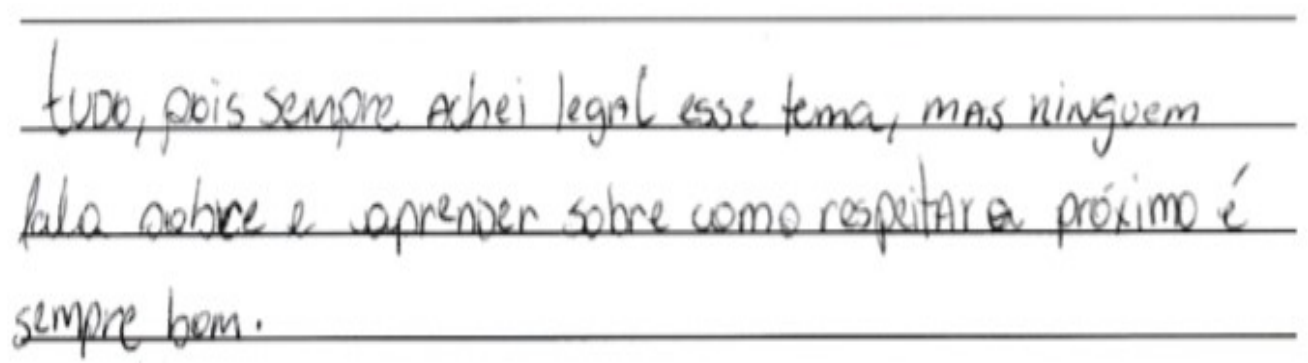

Fonte: Questionário Final

Lara, por sua vez, demonstra ter percebido como a supremacia branca se encontra presente na sociedade: 


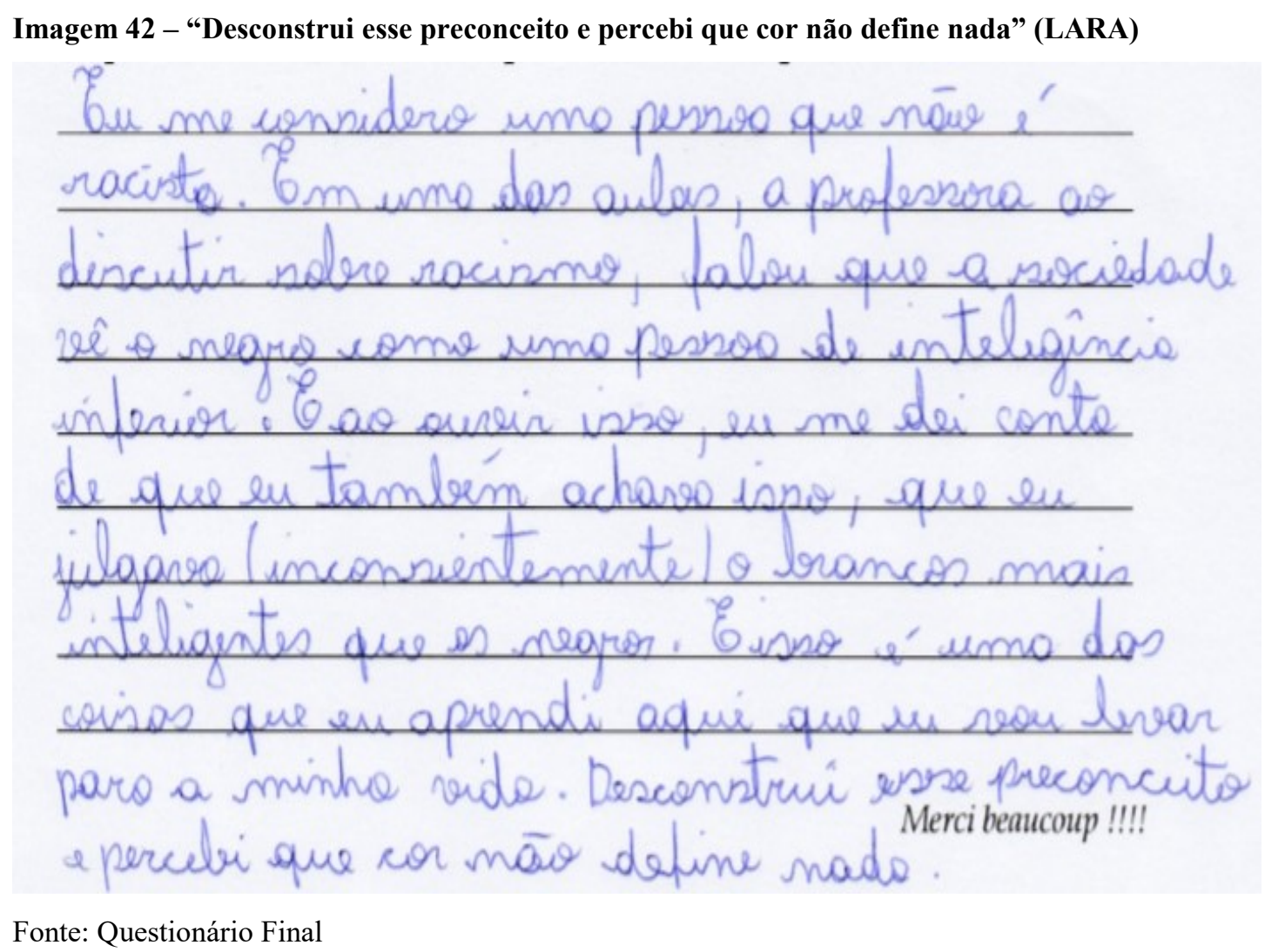

Em seu relato, Lara evidencia o poder da supremacia branca na maneira de ver a/o negra/o na sociedade. Apesar de não prever a discriminação racial, ele interfere nas nossas percepções e valores e, consequentemente, nas nossas atitudes. Observa-se, então, uma mudança na sua percepção da identidade negra pois, ao discutir esses construtos, é possível colocar as pessoas diante dos seus próprios valores racistas e questioná-los (GOMES, 2005b). Como lembra Urzêda Freitas e Pessoa (2012, p. 155), “(...) trabalhar em uma perspectiva crítica significa enfrentar o desafio de problematizar muitas de nossas concepções". Mesmo não tendo se posicionado de maneira tão ativa nas interações ou ainda não tendo entregue nenhuma das Produções Escritas, Lara demonstra ter refletido em sala de aula sobre os discursos das/os colegas, bem como o meu enquanto professora-pesquisadora, ressignificando a maneira como ela vê e entende as identidades de raça/etnia.

Uma vez que nossos valores são acompanhados de práticas, eles merecem ser revistos, mudando, assim, nossos pensamentos para poder transformar a sociedade (GOMES, 2005b). É o que pode ser visto nos relatos de Washington e Roberta: 
Imagem 43 - “(...) importante para qualquer argumento ou opinião que eu tiver que formar ao longo da minha vida (...)" (WASHINGTON)

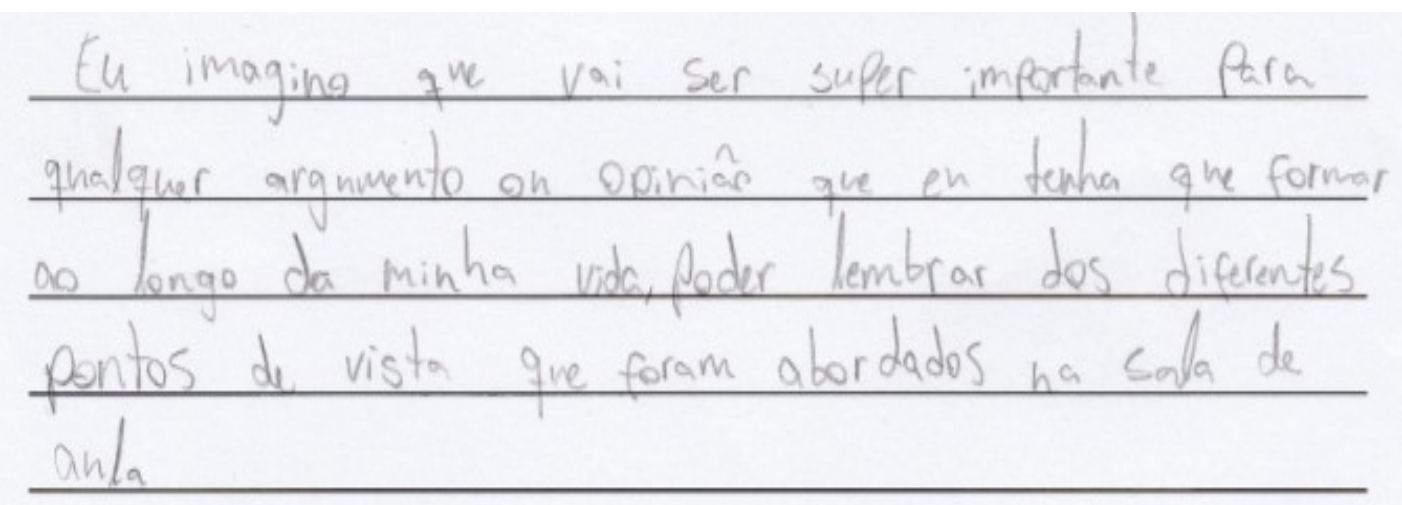

Fonte: Questionário Final

Imagem 44 - “(...) é necessário uma transformação de pensamento” (ROBERTA)

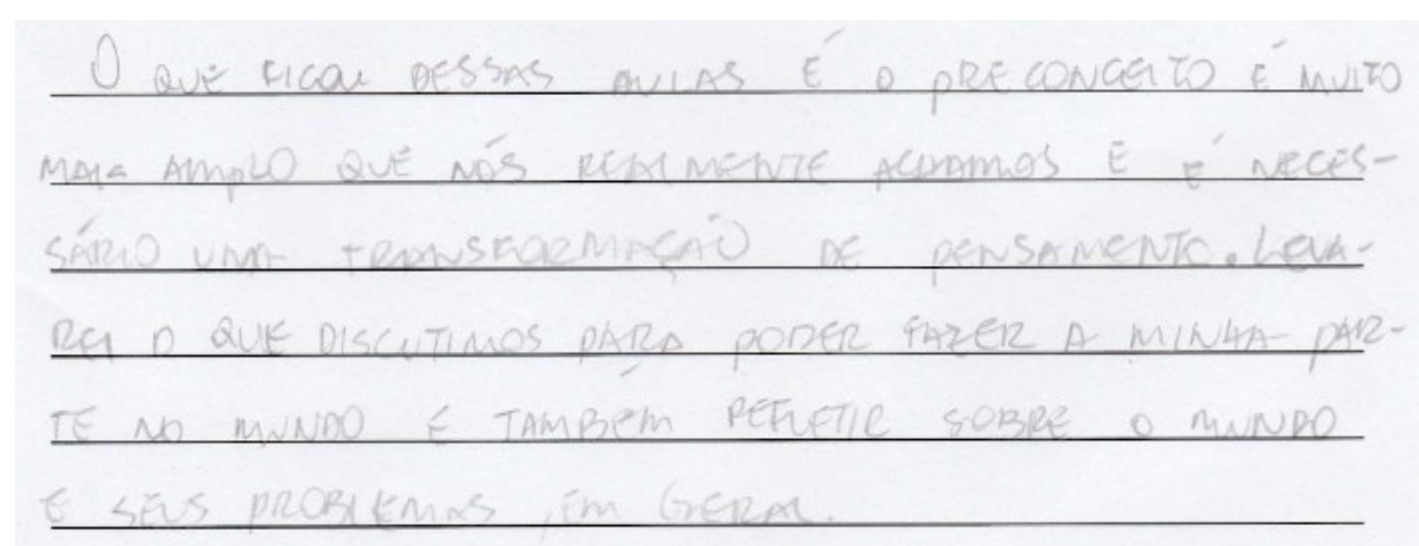

Fonte: Questionário Final

O participante Washington ressalta a importância desse conhecimento para a construção de discursos menos preconceituosos. Nesse sentido, Moita Lopes (2012, p. 10) lembra que "o que se deseja como professor(a) de línguas é o engajamento do aluno no discurso com a esperança que possa usá-lo para fazer escolhas éticas sobre o mundo social que espelhem a possibilidade de refutar qualquer tipo de sofrimento humano".

No letramento crítico, a/o aluna/o se vê como formador/a de opinião, alguém capaz de usar o discurso para agir sobre o mundo e sobre as/os outras/os (FAIRCLOUGH, 2008), transformando a sua realidade, por meio da sua autoria e agência (MONTE MÓR, 2015). Tal situação pode ser vista no texto de Manoca: 


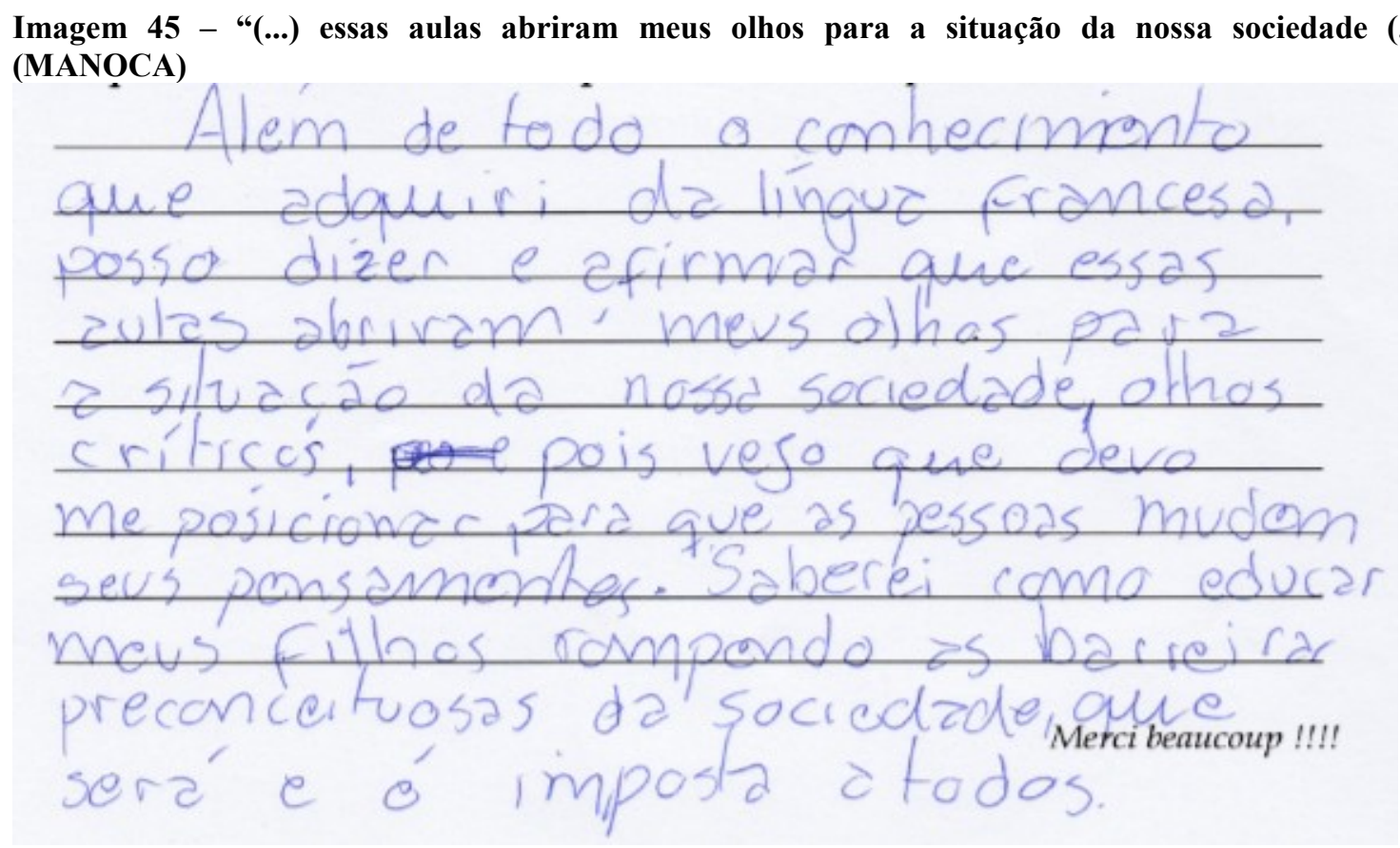

Fonte: Questionário Final

Manoca destaca não apenas o aprendizado da língua francesa, como também o reconhecimento do seu papel de agente na mudança das práticas sociais, evidenciando os desdobramentos de um ensino trangressivo que vai além das barreiras de gênero, raça/etnia, classe social, sexualidade etc. impostas pela sociedade (PENNYCOOK, 2006; HOOKS, 2013). Tal ensino favorece ainda a conscientização crítica da realidade (FREIRE, 2011) em prol de uma sociedade mais justa e igualitária.

A fim de ter uma melhor percepção dos desdobramentos do LC na problematização e (re)construção das identidades sociais de gênero e raça/etnia na sala de aula de lígua francesa, bem como as compreensões das/os participantes do semestre como um todo, reuni alguns excertos das produções escritas das/os alunas/os, bem como do questionário final. Na tabela a seguir, é possível encontrar esses dados:

Tabela 6 - Excertos das/os participantes nas produções escritas e no questionário final

\begin{tabular}{|c|c|c|}
\hline Participantes & $\begin{array}{c}\text { Percepções sobre as identidades } \\
\text { sociais de gênero e raça/etnia }\end{array}$ & $\begin{array}{c}\text { Compreensões sobre o semestre/ } \\
\text { O que ficou dessas aulas }\end{array}$ \\
\hline $\begin{array}{c}\text { Alexandre } \\
\text { Agrigento }\end{array}$ & $\begin{array}{c}\text { "O problema do gênero começa na } \\
\text { sociedade, onde os arquétipos do } \\
\text { gênero masculino e feminino } \\
\text { nasceram." }\end{array}$ & $\begin{array}{c}\text { (...) senti limitado pelas minhas } \\
\text { capacidades expressivas em francês } \\
(. . .) "\end{array}$ \\
\hline Anna W & $\begin{array}{c}\text { "(..) as capas estão frequentemente } \\
\text { cheias de mulheres brancas (...)" }\end{array}$ & $\begin{array}{c}\text { "Interessantes para aprender novos } \\
\text { conceitos em francês (...)” }\end{array}$ \\
\hline
\end{tabular}




\begin{tabular}{|c|c|c|}
\hline Biel & $\begin{array}{c}\text { "A identidade de gênero é saber como } \\
\text { um individuo se identifica na sociedade } \\
\text { (...)" }\end{array}$ & $\begin{array}{l}\text { “(..) além de estudarmos francês, } \\
\text { aprendemos muito sobre como é } \\
\text { grande a desigualdade social (...)” }\end{array}$ \\
\hline Cléo & $\begin{array}{l}\text { “(..) a luta por igualdade para todas } \\
\text { as mulheres é importante (...)” }\end{array}$ & "Foi de imenso ganho pessoal (...)" \\
\hline Johnson & $\begin{array}{c}\text { “A vida tem soluções possíveis para o } \\
\text { racismo, preconceito e as } \\
\text { desigualdades: é a educação (...)" }\end{array}$ & $\begin{array}{l}\text { "Muito bom a tentativa de me } \\
\text { posicionar quanto a tudo isso em } \\
\text { francês (...)" }\end{array}$ \\
\hline José & “(...) Eu sou o que eu quiser ser (...)” & \\
\hline Lara & - & $\begin{array}{l}\text { "Desconstrui esse preconceito e } \\
\text { percebi que cor não define nada" }\end{array}$ \\
\hline Lauren & $\begin{array}{c}\text { "Tudo começa com os brinquedos que } \\
\text { a criança ganha (...)" }\end{array}$ & $\begin{array}{l}\text { “(..) aprender sobre como respeitar } \\
\text { o próximo é sempre bom” }\end{array}$ \\
\hline $\begin{array}{l}\text { Lenor } \\
\text { Estevão }\end{array}$ & $\begin{array}{c}\text { "(...) a única forma de mudar as } \\
\text { desigualdades entre mulheres e } \\
\text { homens e brancos e negros é a } \\
\text { educação (...)”" }\end{array}$ & $\begin{array}{c}\text { "Gostei muito das aulas de francês } \\
\text { deste semestre" }\end{array}$ \\
\hline Manoca & $\begin{array}{l}\text { “(...) a origem da desigualdade no } \\
\text { Brasil vem do passado (...)" }\end{array}$ & $\begin{array}{c}\text { "(...) essas aulas abriram meus olhos } \\
\text { para a situação da nossa sociedade } \\
\text { (...)” }\end{array}$ \\
\hline Roberta & $\begin{array}{c}\text { "Os tempos mudam e é necessário } \\
\text { estabelecer novas regras que incluem } \\
\text { todas as ideias" }\end{array}$ & $\begin{array}{l}\text { “(..) Permitiu olhar o tema em outro } \\
\text { ponto de vista que é normalmente } \\
\text { retratado pela mídia em geral" }\end{array}$ \\
\hline Robervaldo & $\begin{array}{c}\text { "Esta desigualdade tem origem nos } \\
\text { tempos da escravidão quando a mulher } \\
\text { negra era um objeto sexual" }\end{array}$ & $\begin{array}{c}\text { "(..) achei interessante como a } \\
\text { professora embutiu as discussões } \\
\text { com o francês" }\end{array}$ \\
\hline Washington & - & $\begin{array}{c}\text { "(..) interessante abordar temas que } \\
\text { estão presentes a todo momento na } \\
\text { nossa vida (...)" }\end{array}$ \\
\hline
\end{tabular}

Com base nos textos discutidos nessa seção, as/os alunas/os descreveram as aulas como diferentes, por envolver temas que dizem respeito às suas vidas pessoais. Para elas/es, as discussões foram informativas, educativas e interessantes, pois foi possível ter acesso a outras perspectivas de como o preconceito está presente em outras sociedades, além de possibilitar desconstruir seus próprios preconceitos.

Percebe-se que o LC propiciou espaço para a interação e reflexão na aula de língua francesa levando as/os alunas/os a se posicionarem diantes das situações e a se verem como formadoras/es de opinião. Contudo, elas/es ainda tendem a ver essa prática pedagógica de maneira dissociada da língua. Daí a importância de trazer essa abordagem para o ambiente da sala de aula para que professoras/es e alunas/os possam associar o aprendizado da língua a questões sociais presentes no seu cotidiano. Além disso, foi possível repensar a minha prática pedagógica e o meu papel como professora dentro dessa perspectiva de ensino.

Durante o período da pesquisa, observei que as/os alunas/os se sentiram mais confortáveis para usar a língua francesa nas discussões. Acredito que isso se deve não apenas 
ao ganho linguístico, mas à própria abordagem desenvolvida em sala, favorecendo o uso da língua adicional para pensar nas práticas sociais presentes em suas vidas.

Infelizmente não foi possível abordar nas provas os temas críticos discutidos aqui, uma vez que os testes da AF de Brasília são padronizados pela própria instituição, sendo igualmente aplicados a todas as turmas de mesmos nível e público. As/Os professoras/es têm liberdade para escolher o método de avaliação apenas no teste oral do primeiro bimestre no qual levei em consideração as discussões feitas em sala durante as reflexões.

Neste capítulo, discuti os dados gerados durante as aulas de francês por meio da metodologia da pesquisa-ação e dos instrumentos utilizados nesta pesquisa.

No capítulo a seguir, faço algumas considerações finais sobre este estudo. 


\section{CONSIDERAÇÕES FINAIS}

Neste capítulo, apresento as últimas considerações acerca deste trabalho, buscando responder às perguntas de pesquisa encontradas no primeiro capítulo.

\subsection{Retomando as perguntas de pesquisa}

Quando tive acesso às leituras sobre identidades no ensino de línguas e as perspectivas críticas de ensino, busquei desenvolver uma pesquisa que trouxesse esse aporte social, não apenas às/aos minhas/meus alunas/os, como também para minha prática pedagógica. Isso me levou a desenvolver um trabalho de letramento crítico nas aulas de francês procurando problematizar identidades sociais de gênero e raça/etnia tendo, como ponto de partida, algumas inquietações e perguntas que me guiaram durante todo o processo de realização da pesquisa.

Nas seções a seguir, busco responder a cada uma delas tendo como base as discussões feitas no capítulo anterior.

\subsubsection{Quais as percepções das/os participantes sobre as identidades sociais de gênero e raça/etnia? Como elas/es entendem a dinâmica dessas identidades na sociedade?}

Neste trabalho, observei que, de maneira geral, as/os participantes demonstraram, por meio de seus discursos ter uma visão mais crítica da sociedade, indo, muitas vezes, além de opiniões formadas pelo senso comum. Acredito que a maioria delas/es já tinham essa visão antes da pesquisa, sobretudo, as/os participantes Cléo, Alexandre Agrigento e Lenor Estevão, trazendo suas percepções e pontos de vista para fomentar as problematizações. Contudo, houve momentos em que os discursos das/os alunas/os naturalizaram práticas sociais, o que possibilitou refletir sobre elas e buscar compreender o processo histórico e social que levou à sua construção.

Algumas/ns alunas/os, sobretudo as/os da rede privada, se destacaram por ressaltar as diferenças de poder existentes entre as identidades, bem como as intersecções identitárias que trazem diferentes implicações na vida das pessoas (HOOKS, 2010). Elas/es participaram mais ativamente das interações, demonstrando ter uma percepção mais crítica e desnaturalizada das práticas sociais. Acredito que isso advém dos próprios ambientes nos quais elas/es se encontram inseridas/os, seja em casa ou na escola, levando-as/os a desenvolver suas agências 
na busca por textos diversos que constroem discursos sobre as situações do dia a dia, possibilitando melhor compreender as possíveis implicações dessas práticas na sociedade.

\subsubsection{Como o letramento crítico propicia interações e abre espaço para problematização e} (re)construção de identidades em um contexto de francês como língua adicional? Quais as possibilidades e desafios ao desenvolver esse ensino em sala de aula?

Nesta pesquisa, foi possível perceber que o LC nas aulas de francês favorece a problematização de identidades por meio do questionamento das práticas sociais, propiciando a desconstrução de discursos cristalizados e a reflexão sobre as estruturas e hierarquias sociais. Não se pode esquecer, porém, que existem diferentes maneiras de trabalhar com o LC. Afinal, não se trata de uma metodologia, mas de uma maneira de agir em sala de aula (FERREIRA, 2006; DUBOC, 2015). Logo, os resultados apresentados nesta pesquisa trazem algumas possibilidades de desenvolver esse ensino. Outro contexto social traria, portanto, diferentes arranjos na organização e no desenvolvimento da pesquisa. Tendo em vista o contexto de ensino no qual este estudo se encontra - alunas/os provenientes de escolas privadas e públicas interagindo na aprendizagem do francês na AF de Brasília - o trabalho com LC trouxe algumas possibilidades e desafios para problematização e (re)construção de identidades sociais na aula de línguas.

No que tange às possibilidades, observei que esse ensino pode se dar a partir do questionamento de imagens e discursos presentes no próprio livro didático. Nesse sentido, destaco as Atividades II e X que tiveram como base o material previsto em sala de aula, buscando trazer as situações encontradas para a realidade das/os alunas/os. Além disso, foi possível desenvolver esse trabalho por meio de atividades baseadas na estrutura da língua (cf. seção 4.1.8) na qual propus às/os alunas/os que construíssem enunciados levando em conta a estrutura gramatical prevista no livro didático, trazendo exemplos de ações a serem realizadas para diminuir as desigualdades de gêneros. Ademais, refletimos sobre diferentes práticas sociais a partir de atividades de intervenção desenvolvidas ao longo do semestre, abordando situações do dia a dia a fim de incitar a reflexão sobre os eventos presentes em nossas vidas e que passam, muitas vezes, despercebidos. Nesse sentido, as/os próprias/os alunas/os também trouxeram casos a serem debatidos em sala.

Dessa forma, considero que o trabalho dentro da perspectiva do LC pode ser feito nas brechas da sala de aula (DUBOC, 2015), partindo de situações que surgem nesse ambiente de ensino, como também das interações entre as/os alunas/os e a professora-pesquisadora uma 
vez que a configuração da sociedade encontra-se presente na escola com todas as suas crenças, preconceitos e discriminações.

Um dos desafios encontrados foi o uso da língua-alvo, sobretudo no início da pesquisa. As aulas de línguas, em geral, não envolvem discutir e problematizar questões sociais que focam nas desigualdades e relações assimétricas de poder. Muitas vezes, os temas são apenas mencionados sem que se faça uma devida reflexão sobre eles. Logo, as/os alunas/os não estão acostumadas/os a expor seus pontos de vista sobre as práticas sociais em sala de aula, menos ainda a usar a língua francesa para esse fim.

Com o desenrolar da pesquisa, as/os participantes foram ganhando não apenas vocabulário e conhecimentos gramaticais, mas, principalmente, confiança e prática para usar a língua-alvo para falarem de si mesmas/os. Ou seja, as/os estudantes foram se apropriando da língua, usando-a para expressarem suas emoções e sentimentos. Nesse sentido, acredito ser pertinente ressaltar que o uso do português nas interações não se mostrou mais evidente que nas minhas aulas anteriores à pesquisa. Professora de francês há 10 anos, não me recordo de aulas nas quais as/os alunas/os não recorriam ao português, em algum momento, para se esclarecerem melhor seus pontos de vista. Seja em trabalhos em grupo ou diante de toda a turma, era comum as/os alunas/os fazerem uso da língua materna para esclarecessem melhor seus pontos de vista. Diante disso, é possível levantar algumas questões: o português não está sempre presente nas aulas de línguas? Como ele pode contribuir nesse sentido? Ao estudar uma língua, é comum fazermos associações com a nossa língua materna ou até mesmo com outras línguas. Isso nos mostra que as línguas estão em interação e fazem parte do processo de ensino e aprendizagem, seja nas associações mentais ou mesmo nas interações entre as/os alunas/os. Dessa forma, acredito que o uso da língua materna não seja um problema em si. Na verdade, ela contribui para a organização do pensamento e articulação do discurso também na língua-alvo preparando a/o aluna/o para participar dos debates e embates não apenas da sala de aula, mas também fora dela. Contudo, podemos incentivar cada vez mais o uso da línguaalvo, criando oportunidades para usá-la em momentos autênticos nos quais as/os alunas/os possam se posicionar em situações que dizem respeito às suas realidades e vivências, expressando suas opiniões e pensamentos, como foi feito nesta pesquisa.

Outro desafio encontrado foi no planejamento das aulas para conciliar a reflexão dos temas da pesquisa com o livro didático. O material usado em sala abordava diferentes temas, muitas vezes de maneira superficial e neutra, o que possibilitou refletir mais criticamente sobre eles. Quando o livro didático trazia temas voltados para questões de gênero e raça/etnia, eu buscava desenvolver as atividades de intervenção com base nesse material. Quando não, eu 
desenvolvia, à parte, atividades voltadas para tais temas, buscando refletir sobre as construções sociais, bem como as consequências das relações de poder e hierarquias no acesso a espaços privilegiados da sociedade, como: saúde, educação, lazer, trabalho, dentre outros. Essas atividades possibilitaram quebrar com a rotina da sala de aula que, geralmente, é voltada para o livro didático, possibilitando ir além do currículo imposto.

Contudo, o grande desafio que encontrei foi na problematização em si, em quais perguntas fazer e o que esperar das interações. Tendo em vista que essa prática pedagógica exige preparo e formação docente adequada, antes e durante a pesquisa eu ficava muito ansiosa e apreensiva, me questionava como iria conduzir as aulas, o que as/os alunas/os iriam aprender com as discussões, bem como o que iriam perguntar. Procurava informações e possíveis respostas com receio de deixar lacunas, como se fosse possível preencher todos os vazios que as discussões fatalmente vão deixar. Vazios esses que se tornam importantes no momento em que nos leva a outros questionamentos. Buscava, de alguma forma, que as aulas pudessem ajudar as/os alunas/os a refletir sobre diferentes situações da realidade e, se possível, a perceber as relações assimétricas de poder que trazem inúmeras desigualdades e diferentes perspectivas de vida para os sujeitos problematizados nesta pesquisa.

\subsubsection{Quais os desdobramentos do letramento crítico para a (re)construção de identidades} sociais de gênero e raçaletnia, bem como para a formação de cidadãs/os críticas/os e reflexivas/os?

Neste estudo, observou-se que o trabalho com LC na aula de línguas, por meio das discussões feitas em sala, favoreceu a reflexão crítica das/os participantes por possibilitar se expressar sobre temas que, muitas vezes, não encontram o devido espaço nas diferentes instituições da sociedade reconhecidas por construir discursos legitimados, como a família, a igreja, a mídia e até mesmo a escola.

Nas produções escritas, as/os alunas/os construíram textos coesos e coerentes a respeito dos temas debatidos em sala. Elas/es dissertaram e argumentaram, na língua francesa, por meio de exemplos baseados não somente nas discussões, mas também em textos à parte, apontando o desdobramento desse ensino na agência das/os educandos. Em seus textos, elas/es estavam reconstruindo as identidades sociais, ressignificando os sentidos e as imagens correspondentes a elas.

Da mesma forma, no questionário final, as/os alunas/os relataram ter refletido e desconstruído preconceitos, mostrando como as problematizações em sala podem contribuir 
para reconstruir identidades sociais, uma vez que não são fixas nem estáveis (SILVA, 2014; HALL, 2014). Além disso, elas/es demonstraram se ver como pessoas críticas, alguém que reflete sobre as situações da vida social para poder agir na sociedade.

Nesse sentido, percebo que o LC favoreceu a problematização e a reflexão das práticas sociais tanto para as/os alunas/os da rede privada quanto para as/os da rede pública, que, mesmo sem terem deixado suas vozes serem ouvidas como as/os demais, puderam se expressar nas Produções Escritas ou ainda no questionário final, talvez um meio mais seguro que elas/es encontraram para expor suas opiniões. Ademais, com as problematizações em sala de aula, essas/es alunas/os tiveram acesso a diferentes vozes das quais poderão se apropriar para construir seus próprios discursos.

Finalmente, elas/es afirmaram ter aprendido diferentes aspectos da língua francesa, usando-a para se expressarem sobre situações cotidianas de seu interesse. Percebe-se que esse trabalho permitiu desenvolver as capacidades linguístico-discursivas das/os participantes, a competência política e a conscientização crítica tão preconizada por Freire (2011). Assim, pode-se dizer que o LC trouxe desdobramentos positivos para a (re)construção de identidades sociais de gênero e raça/etnia cujos sentidos foram ressignificados, favorecendo a formação de cidadãs/os críticas/os e reflexivas/os para que possam agir na democracia em busca de uma sociedade menos opressora e desigual. Contudo, acredito que a pedagogia crítica não pode ser vista como uma resposta aos problemas da sociedade, caso contrário voltamos para a concepção de escola como redentora da verdade absoluta. A meu ver, a escola deve ser vista como mais um espaço onde é possível e desejável discutir questões sociais que dizem respeito à vida das/os alunas/os, tendo em vista que ela lida com a diversidade que se encontra na própria sociedade, possibilitando ter acesso a diferentes realidades e pontos de vista.

\subsection{Algumas reflexões finais}

Tendo respondido às perguntas que nortearam este trabalho, volto agora para a pergunta que surgiu com o estudo: de que maneira práticas de letramento crítico em aulas de francês língua adicional podem (re)construir identidades docentes?

Com base na discussão dos dados, percebo que, mesmo que inconscientemente, eu buscava ter respostas para as perguntas que pudessem surgir em sala. Durante o semestre no qual a pesquisa foi desenvolvida, procurava ler muitos textos acadêmicos ou sobre casos de sexismo e racismo em sites que se voltavam para discutir essas questões. Procura ver filmes, documentários e programas que ressaltassem os temas de gênero e raça/etnia. Em outras 
palavras, buscava estar preparada para as aulas, assim como exige a própria perspectiva crítica de ensino. Procurava não deixar lacunas, ter argumentos sólidos, de fato convencer. Acredito que essa reação adveio das minhas vivências enquanto aluna. Na sociedade, ainda é forte a crença de que a/o professor/a deve saber tudo e ter respostas prontas, como se fosse a/o detentor/a do saber. Fui acostumada, ao longo da vida, a ter professoras/es que falavam durante toda a aula, enquanto eu ouvia e escrevia. Não fui devidamente levada a me posicionar, a ter voz em sala de aula, a ir contra a opinião da/o professor/a, aliás, isso sempre era visto como ruim e mal educado. Ao me ver como professora, eu assumi, inconscientemente, esse papel.

Com a discussão dos dados, percebo que, mesmo procurando dar espaço para as/os alunas/os se posicionarem e expressarem suas opiniões sem sofrerem retaliações, muitas vezes, me vi como detentora da verdade, como se existisse uma verdade absoluta. Percebo que, mesmo sem querer, eu tomei para mim um papel redentorista, alguém que devesse revelar a verdade sobre os fatos, abrindo a consciência das/os alunas/os para, quem sabe, transformá-las/os. Acreditava ser esse o meu papel, por ter construindo essa imagem de professor/a desde a minha experiência como aluna. Da mesma forma, buscava um fechamento ao final das atividades, uma espécie de moral a ser aprendida no final da aula. Em nossas vidas, somos levadas/os a tirar conclusões das situações, seja em uma conferência, em uma leitura ou nos textos que produzimos. Somos constantemente levadas/os a concluir e a fechar as ideias e os pensamentos.

Minha prática pedagógica ia além da problematização. Era relevante chegar a algum lugar, ter e ver resultados. Isso me levou a conduzir as aulas para alguns pontos, como se, no final, as/os alunas/os tivessem que ter aprendido o que estava previsto para aquele dia. Isso nos remete, mais uma vez, ao ensino conteudista ao qual estamos acostumadas/os e que prevê, em seus planejamentos, um início, um meio e um fim. Com base nisso, percebo que o meu papel como professora não envolve esse peso de ter respostas para tudo, de ter conclusões e resultados nas minhas aulas. Não visa mudar as opiniões das/os alunas/os nem a chegar necessariamente em algum lugar. Meu trabalho, dentro dessa perspectiva de ensino, envolve desnaturalizar as identidades. Daí surge outro questionamento: como fazê-lo? Sendo neutra, apenas mediando a discussão? Desnaturalizar envolve desconstruir o que já está dado de antemão e refletir sobre o processo de construção das práticas sociais passando por questões históricas, sociais, culturais, políticas etc. envolvidas no processo. Logo, o papel da/o professor/a não é de simples mediador/a, mas sim de favorecer condições para a desnaturalização. 
Nesta pesquisa, encontrei dificuldade em como agir em sala de aula, pois assumi concomitantemente diversos papéis: o de professora, pesquisadora, participante, mulher, parda, brasileira, dentre outros. Esses papéis se mesclaram, formando a minha identidade. A depender da situação, vamos assumindo tais identidades, fazendo prevalecer uma ou outra. No início da pesquisa, acreditava que a minha identidade como professora deveria prevalecer sobre as demais, sendo a protagonista no momento em que estivesse em sala de aula. Contudo, uma vez em sala, não é possível desconectá-las ou deixá-las de lado, pois estão em interação. Elas são instáveis, contraditórias e transitórias (HALL, 2014; WOODWARD, 2014; SILVA, 2014; MASTRELLA DE ANDRADE, 2013). Eu estava ali repleta de emoções e desejos assim como prevê a própria metodologia da pesquisa-ação, que reconhece o caráter subjetivo da/o pesquisador/a que está presente na pesquisa "com todo o seu ser emocional, sensitivo, axiológico", bem como com o seu ser "dubidativo, metódico, crítico, mediador, enquanto pesquisador profissional" (BARBIER, 2007, p. 69).

Assim, a discussão dos dados me levou a refletir sobre o meu papel como professora e hoje percebo que cabe a mim proporcionar ambiente favorável para que as/os alunas/os possam opinar e expor seus pontos de vista sobre as diferentes práticas sociais. Dessa forma, o que conta é a problematização em si, o processo e não o resultado. Hoje me sinto mais segura de alguma forma e mais consciente do meu trabalho. Sei que esse caminho é trilhado dia a dia e que sempre será construído, não acredito que ele tenha fim, pois estamos constantemente aprendendo e ressignificando nossos conhecimentos. Espero desenvolver o meu trabalho de maneira ainda mais consciente para que eu possa, juntamente com minhas/meus alunas/os, refletir e ter consciência das nossas realidades e dos nossos preconceitos.

Ademais, acredito que essa prática de pensar sobre as situações da vida deveria ser encorajada nos cursos de formação profissional, para que as/os professoras/es possam, cada vez mais, encontrar brechas na sala de aula para refletir sobre questões identitárias, favorecendo, assim, a formação cidadã e capacitando as/os alunas/os a construir seus próprios discursos para agir em prol de uma sociedade mais justa e igualitária. É a educação como prática da liberdade (FREIRE, 2011), um ensino que permite transgressões, "um movimento contra as fronteiras e para além delas" (HOOKS, 2011, p. 24). Não podemos esquecer que a sala de aula é a configuração da sociedade, é espaço de construção de identidades. Logo, as/os alunas/os ali presentes estão interagindo e se reconstruindo como sujeitos. A escola torna-se, então, um espaço propício para trabalhar as diferenças e as configurações da sociedade. Isso nos leva à concepção de escola ressaltada por John Dewey, que a concebe não como espaço de aprendizado para a vida, mas a própria vida. 


\section{REFERÊNCIAS}

ALMEIDA FILHO, J. C. P. Dimensões comunicativas no ensino de línguas. 7. ed. São Paulo: Pontes, 2013.

AUAD, D. Educação para a democracia e co-educação: apontamentos a partir da categoria gênero. Revista USP, São Paulo, n. 56, p. 136-143, dez./fev. 2002-2003.

AZEVEDO. A. S. Reconstruindo identidades discursivas de raça na sala de aula de língua estrangeira. 2010. 185 f. Dissertação (Mestrado em Linguística Aplicada) Faculdade de Letras da Universidade Federal do Rio de Janeiro, Rio de Janeiro, 2010.

BARBIER, R. A Pesquisa-Ação. Tradução Lucie Didio. Brasília: Liber Livro Editora, 2007.

BAUMAN, Z. Modernidade líquida. Tradução Plínio Dentzien. Rio de Janeiro: Zahar, 2001.

Identidade. Tradução Carlos Alberto Medeiros. Rio de Janeiro: Zahar, 2005.

BEAUVOIR, S. O Segundo Sexo. 2. ed. Rio de Janeiro: Nova Fronteira, 2009.

BORTONI-RICARDO, S. M. O professor pesquisador: introdução à pesquisa qualitativa. São Paulo: Parábola, 2008.

BOURDIEU, P. A Economia das Trocas Lingüísticas. In: ORTIZ, R. (Org.). Pierre Bourdieu: sociologia. São Paulo: Ática, 1994.

BRASIL. Parâmetros Curriculares Nacionais: terceiro e quarto ciclos do ensino fundamental: língua estrangeira. Brasília: MEC/SEF, 1998.

Lei Federal n. ${ }^{\circ}$ 10.639, de 9 de janeiro de 2003. Altera a Lei no 9.394 , de 20 de dezembro de 1996, que estabelece as diretrizes e bases da educação nacional, para incluir no currículo oficial da Rede de Ensino a obrigatoriedade da temática "História e Cultura AfroBrasileira", e dá outras providências. Disponível em: $<$ http://www.planalto.gov.br/ccivil 03/leis/2003/L10.639.htm $>$. Acesso em: 12 dez. 2015, 10:45:50.

Diretrizes Curriculares Nacionais para a Educação das Relações Étnico-Raciais e para o Ensino de História e Cultura Afro-Brasileira e Africana. Brasília: MEC, 2004. Disponível em: $<$ http://www.acaoeducativa.org.br/fdh/wp-content/uploads/2012/10/DCN-sEducacao-das-Relacoes-Etnico-Raciais.pdf $>$. Acesso em: 13 dez. 2015, 13:23:54.

Tecnologias. Brasília: $\quad$ MEC, $2006 . \quad$ Disponível em:

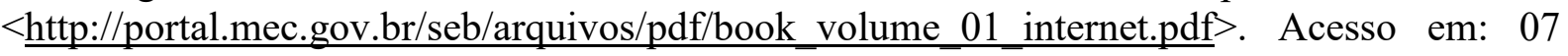
dez. 2015, 14:45:32.

- Gênero e diversidade na escola: formação de professoras/es em gênero, sexualidade, orientação sexual e relações étnico-raciais. Rio de Janeiro: CEPESC; Brasília: SPM, 2009. 
Lei n. 9.394, de 20 de dezembro de 1996. Estabelece as diretrizes e bases da educação nacional. 9. ed. Brasília: Edições Câmara, 2014.

. Mapa da Violência 2015: homicídio de mulheres no Brasil. Brasília: Nações Unidas para a Igualdade de Gênero e Empoderamento das Mulheres, 2015. Disponível em: $<$ http://www.mapadaviolencia.org.br/pdf2015/MapaViolencia_2015_mulheres.pdf $>$. Acesso em: 16. fev. 2016, 12:34:12.

- Base Nacional Comum Curricular. Brasília: MEC, 2016. Disponível em:

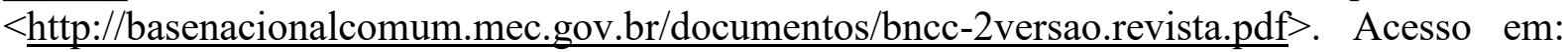
05 set. 2016, 19:58:54.

BUTLER, J. Corpos que pesam: sobre os limites discursivos do "sexo". In: LOPES LOURO, G. (Org.). O corpo educado: Pedagogias da sexualidade. Belo Horizonte, Autêntica, 1999. p. 151-172.

CARNEIRO, S. A mulher negra na sociedade brasileira: o papel do movimento feminista na luta anti-racista. In: MUNANGA, K. (Org.). O negro na sociedade brasileira: resistência, participação, contribuição. v. 1. Brasília: Fundação Cultural Palmares, 2004. p. 286-336.

CELANI, M. A. A. Questões de ética na pesquisa em Linguística Aplicada. Linguagem \& Ensino. Pelotas, v. 8, n. 1, p. 101-122, jan./jun. 2005.

CHIZZOTTI, A. Pesquisa qualitativa em ciências humanas e sociais. 4. ed. Petrópolis: Vozes, 2011.

CRUZ, A. C. J.; RODRIGUES, T. C.; BARBOSA, L. M. A. Apontamentos teóricos para a educação das relações étnico-raciais no Brasil: contextos e conceitos. In: BARBOSA, L. M. A. (Org.). Relações étnico-raciais em contexto escolar: fundamentos, representações e ações. São Carlos: EdUFSCar, 2011. p. 11-37.

DAMASCO, D. G. B. Contando uma história: o ensino público de línguas estrangeiras a partir das interpretações de jovens e de docentes do Distrito Federal. 2014. 463 f. Tese (Doutorado em Educação) - Universidade de Brasília, Brasília, 2014.

DENZIN, N. K; LINCOLN, Y, S. O planejamento da pesquisa qualitativa: teorias e abordagens. 2. ed. Porto Alegre: Artmed, 2006.

DUBOC. A. P. Letramento crítico nas brechas da sala de línguas estrangeiras. In: TAKAKI, N. H.; MACIEL, R. F. (Orgs.). Letramentos em terra de Paulo Freire. 2. ed. São Paulo: Pontes Editores, 2015. p. 209-229.

FAIRCLOUGH, N. Discurso e mudança social. Tradução de Izabel Magalhães. Brasília: Editora Universidade de Brasília, 2008.

FERNANDES, L. R. Uma experiência de ensino crítico com alunas/os iniciantes de inglês: foco em gênero e sexualidade. 2012. 128 f. Dissertação (Mestrado em Letras e Linguística) - Universidade Federal de Goiás, Goiânia, 2012.

FERREIRA, A. J. Formação de professores: raça/etnia. Cascavel: Coluna do Saber, 2006. 
Identidades sociais de raça/etnia na sala de aula de língua inglesa. In: FERREIRA, A.

J. (Org.). Identidades sociais de raça, etnia, gênero e sexualidade: práticas pedagógicas em sala de aula de línguas e formação de professores/as. São Paulo: Pontes Editores, 2012. p. 1950 .

.; BRIGOLLA, F. C. A representação de gêneros em livros didáticos de língua inglesa. Revista Uniabeu, Rio de Janeiro, v. 6, n. 14, p. 01-19, set./dez. 2013.

Narrativas autobiográficas de professoras/es de línguas na universidade: letramento racial crítico e teoria racial crítica. In: FERREIRA, A. J. (Org.). Narrativas autobiográficas de identidades sociais de raça, gênero, sexualidade e classe em estudos da linguagem. São Paulo: Pontes Editores, 2015. p. 127-159.

., FERREIRA, S. A. Raça/etnia, gênero e suas implicações na construção das identidades sociais em sala de aula. Revista Virtual de Letras, Jataí, v. 03, n. 02, p. 114-129, ago./dez. 2011.

FERREIRA, S. A. Percepções das identidades sociais de raça/etnia e gênero na escola: vozes de professoras e alunos/as. 2011. 109 f. Dissertação (Mestrado em Letras) Universidade Estadual do Oeste do Paraná, Cascavel, 2011.

FLICK, U. Introdução à pesquisa qualitativa. 3. ed. Porto Alegre: Artmed, 2009.

FOUCAULT, M. A ordem do discurso: aula inaugural no Collège de France, pronunciada em 2 de dezembro de 1970. Tradução Laura Fraga de Almeida Sampaio. 21. ed. São Paulo: Edições Loyola, 2011. 79 p.

FRANCO, M. A. S. Pedagogia da Pesquisa-ação. Educação e Pesquisa, São Paulo, v. 31, n. 3, set./dez. 2005, p. 483-502.

FREIRE, P. Pedagogia do oprimido. 50. ed. Rio de Janeiro: Paz e Terra, 2011.

FREYRE, G. Casa-grande e senzala. 50. ed. Rio de Janeiro: José Olympio, 2005.

GIDDENS, A. As conseqüências da modernidade. 2. ed. São Paulo: Editora da Universidade Estadual Paulista, 1991.

GIESEL, C. C. M. Uma abordagem sociointeracionista humanizadora para o ensino de línguas estrangeiras: gênero na sala de aula. In: FERREIRA, A. J. (Org.). Identidades sociais de raça, etnia, gênero e sexualidade: práticas pedagógicas em sala de aula de línguas e formação de professores/as. São Paulo: Pontes Editores, 2012. p. 101-120.

GIROUX, H. A. Cruzando as Fronteiras do Discurso Educacional: novas políticas em educação. Porto Alegre: Artes Médicas, 1999. 
GOMES, N. L. Educação, raça e gênero: relações imersas na alteridade. Cadernos Pagu, São Paulo, v. 6-7, p. 67-82, 1996.

Alguns termos e conceitos presentes no debate sobre relações raciais no Brasil: uma breve discussão. In: BRASIL, MINISTÉRIO DA EDUCAÇÃO. Educação anti-racista: caminhos abertos pela Lei Federal n. ${ }^{\circ}$ 10. 639/03. Secretaria de Educação Continuada, Alfabetização e Diversidade. Brasília: MEC, 2005a.

Educação e relações raciais: refletindo sobre algumas estratégias de atuação. In: MUNANGA, K. (Org.). Superando o racismo na escola. 2. ed. Brasília: MEC, 2005b. p. 143-154.

. Diversidade cultural, currículo e questão racial: desafios para a prática pedagógica. In: ABRAMOWICZ, A.; BARBOSA, L. M. A.; SILVÉRIO, V. (Orgs.). Educação como prática da diferença. São Paulo: Armazém do Ipê, 2006.

HALL, S. A identidade cultural na pós-modernidade. Tradução Tomaz Tadeu da Silva. Rio de Janeiro: Lamparina, 2014.

HERINGER, R. Mapeamentos das ações e discursos de combate às desigualdades raciais no Brasil. Estudos Afro-Asiáticos, Rio de Janeiro, v. 23, n. 2, p. 1-43, 2001.

HOELZLE, M. J. L. R. Desestabilisando sociabilidades em uma sala de aula de língua inglesa de uma escola pública. 2016. 173 f. Dissertação (Mestrado em Letras e Linguística) - Universidade Federeal de Goiás, Goiânia, 2016.

HOOKS, B. Teaching critical thinking: practical wisdom. New York, London: Routledge, 2010.

Ensinando a transgredir: a educação como prática da liberdade. São Paulo: WMF Martins Fontes, 2013.

Mulheres negras: moldando a teoria feminista. Tradução de Roberto Cataldo Costa. Revista Brasileira de Ciência Política, Brasília, n. 16, p. 193-210, jan./ abr. 2015.

JORDÃO, C. M. A posição de professor de inglês no Brasil: hibridismo, identidade e agência. R. Let. \& Let., Uberlândia - MG, v. 26, n. 2, p. 427-442, jul./dez. 2010.

Birds of different feathers: algumas diferenças entre letramento crítico, pedagogia crítica e abordagem comunicativa. In: TAKAKI, N. H.; MACIEL, R. F. (Orgs.). Letramentos em terra de Paulo Freire. 2. ed. São Paulo: Pontes Editores, 2015. p. 195-207.

LOURO, G. L. Gênero, sexualidade e educação: uma perspectiva pós-estruturalista. 6 . ed. Rio de Janeiro: Editora Vozes, 2003. 
. Gênero e sexualidade: pedagogias contemporâneas. Pró-Posições, São Paulo, v. 19, n. 2 (56), p. 17-23, maio/ago. 2008.

LÜDKE, M; ANDRÉ, M, E. D. A. Pesquisa em educação: Abordagens Qualitativas. 2. ed. Rio de Janeiro: E.P.U., 2013.

MASTRELLA, M. R. Inglês com língua estrangeira: entre o desejo do domínio e a luta contra a exclusão. 2007. 321 f. Tese (Doutorado em Estudos Linguísticos) - Universidade Federal de Goiânia, Goiânia, 2007.

MASTRELLA-DE-ANDRADE. Pós-modernidade e ensino de línguas estrangeiras: tendências e desafios. Horizontes de Linguística Aplicada, Brasília, v. 9, n. 1, p. 102-117, 2010.

- Pensando identidades em contextos de ensino-aprendizagem de línguas: uma discussão teórica introdutória. In: FIGUEREDO, C. J.; MASTRELA-DE-ANDRADE, M. R. (Orgs.). Ensino de Línguas na Contemporaneidade: Práticas de Construção de Identidades. São Paulo: Pontes, 2013, p. 17-60.

MATTOS, A. M. A. Construindo cidadania nas aulas de inglês: uma proposta para o letramento crítico. In: TAKAKI, N. H.; MACIEL, R. F. (Orgs.). Letramentos em terra de Paulo Freire. 2. ed. São Paulo: Pontes Editores, 2015. p. 171-191.

MENEZES DE SOUSA, L. M. T. Para uma redefinição de letramento crítico: conflito e produção de significação. In: MACIEL, R. F.; ARAÚJO, V. A. (Org.) Formação de professores de línguas: ampliando perspectivas. Jundiaí: Paco Editorial, $2011 \mathrm{a}$.

. O professor de inglês e os letramentos no século XXI: métodos ou ética?. In: JORDÃ̃ et al (Org.). Formação "desformatada" práticas com professores de língua inglesa. Campinas, SP: Pontes, 2011b, p. 279-303.

MOITA LOPES, L. P. Pesquisa interpretativista em Lingüística Aplicada: a linguagem como condição e solução. Delta, São Paulo, v. 10, n. 2, p. 329-338, 1994.

Oficina de lingüística aplicada: a natureza social e educacional dos processos de

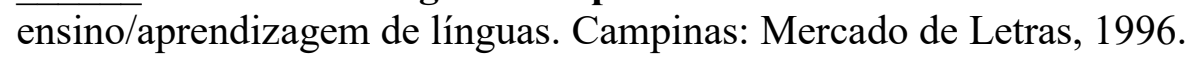

. Linguagem e escola na construção de quem somos. In: FERREIRA, A. J. (Org.). Identidades sociais de raça, etnia, gênero e sexualidade: práticas pedagógicas em sala de aula de línguas e formação de professores/as. São Paulo: Pontes Editores, 2012. p. 9-12.

MONTE MÓR, W. Crítica e letramentos críticos: reflexões preliminares. In: ROCHA, C. H.; MACIEL, R. F. (Orgs.). Língua estrangeira e formação cidadã: por entre discursos e práticas. São Paulo: Pontes Editores, 2015. p. 31-50.

MORIN, E. Introdução ao pensamento complexo. Tradução de Eliane Lisboa. 4. ed. Porto Alegre: Sulina, 2011.

MUNANGA, K. Apresentação. In: MUNANGA, K. (Org.). Superando o racismo na escola. 2. ed. Brasília: MEC, 2005. p. 15-20. 
NICOLAIDES, C. S.; TILIO, R. C. Políticas de ensino e aprendizagem de línguas adicionais no contexto brasileiro: o caminho trilhado pela ALAB. In: NICOLAIDES, C.; SILVA, K. A.; TILIO, R.; ROCHA, C. H. (Orgs.). Políticas e políticas linguísticas. São Paulo: Pontes Editores, 2013.

NORTON, B. Identity and Language Learning: Gender, Ethnicity and Educational Change. Harlow, England: Pearson Education, 2000.

.; TOOHEY, K. Changing Perspectives on Good Language Learners. Tesol Quarterly, Ontário, v. 35, n. 2, p. 307-322. 2001.

OLIVEIRA, E. Mulher negra professora universitária: trajetória, conflitos e identidades. Brasília: Líber Livro Editora, 2006.

PENNYCOOK, A. Critical Applied Linguistics: a critical introduction. Mahwah, NJ: Lawrence Erlbaum Associates, 2001.

. Uma lingüística aplicada transgressiva. In: MOITA LOPES, L. P. (Org.). Por uma lingüística aplicada indisciplinar. São Paulo: Parábola, 2006. p. 67- 84.

- Critical and alternative directions in applied linguistics. Australian Review of Applied Linguistics, Australia, Monash University, v. 33, n. 2, p. 16.1-16.6, 2010.

RESENDE, V. M. Análise de discurso crítica e etnografia: o movimento nacional de meninos e meninas de rua, sua crise e protagonismo juvenil. 2008. 332 f. Tese (Doutorado em Linguística) - Universidade de Brasília, Brasília, 2008.

SANTERINI, M. Reconnaître et prévenir le néo-racisme. Strasbourg: Conseil de l'Europe, 2015. Disponível em: $\quad \underline{\mathrm{http}}$ ://assembly.coe.int/nw/xml/XRef/Xref-DocDetailsfr.asp?FileId=21803 $>$. Acesso em: 13 dez. 2015, 12:16:13.

SANTOS, B. S. Pela Mão de Alice: o social e o político na pós-modernidade. 6. ed. São Paulo: Ed. Cortez, 1999.

SCOTT, J. Gênero: uma categoria últil para análise histórica. Educação e Realidade, Porto Alegre, v. 20, n. 2, p. 71-79, jul./dez. 1995.

SILVA, P. B. G. Ensinar, aprender e relações étnico-raciais no Brasil. Educação, Porto Alegre, ano XXX, n. 3 (63), set./dez. 2007. p. 489-506.

SILVA, T. T. (Org.). A produção social da identidade e da diferença. In: SILVA, Tomaz Tadeu da (Org.). Identidade e diferença: a perspectiva dos estudos culturais. 15. ed. Petrópolis: Vozes, 2014. p. 73-102.

STAKE, R. E. Pesquisa qualitativa: estudando como as coisas funcionam. Porto Alegre: Penso, 2011.

SOARES, M. Letramento: um tema em três gêneros. Belo Horizonte: Autêntica, 1998. 
. Letramento e alfabetização: as muitas facetas. Revista Brasileira de Educação, Minas Gerais, jan./fev./mar./abr. 2004, p. 5-17. Disponível em: $<$ http://www.scielo.br/pdf/rbedu/n25/n25a01.pdf $>$. Acesso em: 29 dez. 2015, 14:29:35.

TELLES, E. Racismo à brasileira: uma nova perspectiva sociológica. Rio de Janeiro: Relume Dumará, 2003.

THOMPSON, J. B. Ideologia e cultura moderna: teoria social crítica na era dos meios de comunicação de massa. 2. ed. Petrópolis: Vozes, 1990.

TILIO, R. A construção social de gênero e sexualidade em livros didáticos de inglês: que vozes circulam? In: FERREIRA, A. J. (Org.). Identidades sociais de raça, etnia, gênero e sexualidade: práticas pedagógicas em sala de aula de línguas e formação de professores/as. São Paulo: Pontes Editores, 2012. p. 121-143.

Repensando a abordagem comunicativa: multiletramentos em uma abordagem consciente e conscientizadora. In: ROCHA, C. H.; MACIEL, R. F. (Orgs.). Língua Estrangeira e Formação Cidadã: Por entre Discursos e Práticas. São Paulo: Pontes, 2015a. p. 51-67.

. Enfoque em leitura no ensino de inglês: PCN e letramento crítico. In: SILVA, K. A.; ARAÚJO, J. (Orgs.). Letramentos, discursos midiáticos e identidades: novas perspectivas. São Paulo: Pontes Editores, 2015b. p. 257-287.

URZÊDA FREITAS, M. T. ; PESSOA, R. P. Gênero, Sexualidade e ensino crítico de língua estrangeiras: intersecções com a formação de professores/as. In: FERREIRA, A. J. (Org.). Identidades sociais de raça, etnia, gênero e sexualidade: práticas pedagógicas em sala de aula de línguas e formação de professores/as. São Paulo: Pontes Editores, 2012. p. 145-165.

Ensino de línguas como transgressão: corpo, discursos de identidades e mudança social. Jundiaí: Paco Editorial, 2013.

WOODWARD, K. Identidade e diferença: uma introdução teórica e conceitual. In: SILVA, Tomaz Tadeu da (Org.). Identidade e diferença: a perspectiva dos estudos culturais. 15. ed. Petrópolis: Vozes, 2014. p. 07-72. 


\section{APÊNDICE 1 - QUESTIONÁRIO INICIAL}

\section{Questionário Inicial}

Nome:

Idade:

Data:

Sexo: ( ) masculino ( ) feminino ( ) outro

Você se considera: ( ) branca/o ( ) negra/o ( ) parda/o ( ) amarela/o ( ) outro

1) Em que cidade você mora?

2) Com quem você mora?

3) Onde você estuda (o ensino regular)? Está cursando qual ano/série?

4) Você acha importante estudar francês? Por quê?

5) Por que você estuda francês na Aliança Francesa? O que mais te atrai?

6) Você já discutiu temas sociais nas aulas de francês? Se sim, quais?

7) Você acha importante discutir temas sociais em sala de aula? Por quê? 
APÊNDICE 2 - QUESTIONÁRIO DA ATIVIDADE II

Nome:

Data:

1) Como você se sentiu na aula de hoje? Você gostou de discutir sobre esse tema em sala de aula? Por quê? 
APÊNDICE 3 - QUESTIONÁRIO DA ATIVIDADE III

Nome:

Data:

1) Como você se sentiu na aula de hoje?

2) O que você achou de discutir sobre o tema?

3) O que mais te chamou atenção?

4) Você teve alguma dificuldade de falar em francês?

5) O que você aprendeu na aula de hoje? 
APÊNDICE 4 - QUESTIONÁRIO DA ATIVIDADE IV

Nome:

Data:

1) Complete as frases:

Nessa aula eu me senti

Discutir sobre o tema na aula de língua francesa foi

O que mais me chamou atenção foi

Eu tive facilidades/dificuldades em

Eu aprendi que 
APÊNDICE 5 - QUESTIONÁRIO DAS ATIVIDADES VI, VII E IX

Nome:

Pseudônimo :

Tema:

Data:

1. Como você se sentiu na aula de hoje?

2. O que você achou da atividade proposta?

2) Como foi discutir o tema em francês?

3) O que você aprendeu com a atividade?

Merci beaucoup !!!! 
APÊNDICE 6 - QUESTIONÁRIO FINAL

\section{Questionário Final}

Nome:

Pseudônimo :

Data:

1. Como você descreveria as aulas de francês desse semestre?

2. O que ficou dessas aulas? O que você vai levar para sua vida? 


\section{APÊNDICE 7 - PRODUÇÃO ESCRITA I}

\section{Production Écrite I}

Nom:

Date:

Tu dois écrire un éditorial pour le journal de ton école sur le thème : La construction du genre féminin et masculin dans la société : origine et conséquences. Pour cela, tu peux aborder les thèmes travaillés en classe. Minimum 20 lignes. 
APÊNDICE 8 - PRODUÇÃO ESCRITA II

\section{Production Écrite II}

Nom:

Date:

Tu dois écrire un éditorial pour le journal de ton école sur le thème : Les inégalités entre les femmes blanches et noires au Brésil : quelles origines, conséquences et possibles solutions? Pour cela, tu peux aborder les thèmes travaillés en classe. Minimum 25 lignes. 


\section{APÊNDICE 9 - TERMO DE CONSENTIMENTO LIVRE E ESCLARECIDO - ESCOLA}

\section{TERMO DE CONSENTIMENTO LIVRE E ESCLARECIDO}

Venho, por meio deste, solicitar a sua colaboração para a minha pesquisa de Mestrado em Linguística Aplicada na Universidade de Brasília (UnB) sobre a problematização de identidades sociais na sala de aula de francês. Esta pesquisa busca refletir sobre questões sociais ligadas às culturas francófona e brasileira e está sob a orientação da Profa. Dra. Mariana R. Mastrella-de-Andrade (UnB).

Nesta pesquisa, o trabalho será feito com o método e os materiais de estudo previstos pela Aliança Francesa de Brasília, problematizando o próprio material, juntamente com materiais extras que abordam temas sociais e culturais. Quanto aos possíveis benefícios aos participantes deste estudo, destacamos a oportunidade de reflexão crítica acerca da realidade social em geral, competência cada vez mais demandada pelos exames nacionais e vestibulares.

Em vista disso, gostaria de solicitar a sua colaboração na coleta de dados para realização desta pesquisa. Os dados serão utilizados na elaboração da dissertação e em eventuais artigos e apresentações. Sob nenhuma forma serão divulgados os dados pessoais ou revelada a identidade dos participantes quando da divulgação da pesquisa. Comprometo-me a dar uma devolutiva à escola, bem como aos participantes, quanto aos resultados da pesquisa.

Uma via original deste Termo de Consentimento Livre e Esclarecido ficará com você.

Qualquer dúvida a respeito da pesquisa, você poderá entrar em contato comigo pelo telefone (61) 8318-5800 ou pelo e-mail: walescaporto@gmail.com.

Desde já, agradeço a sua atenção e colaboração para a realização desta pesquisa.

Brasília, de de 2016.

Walesca Afonso Alves Pôrto

Eu, diretora da Aliança Francesa de Brasília, autorizo a realização da pesquisa citada acima após ter sido devidamente esclarecida. Autorizo ainda, por minha livre e espontânea vontade, a divulgação do nome desta escola onde a pesquisa será realizada. 


\section{APÊNDICE 10 - TERMO DE CONSENTIMENTO LIVRE E ESCLARECIDO - ALUNAS/OS}

\section{TERMO DE CONSENTIMENTO LIVRE E ESCLARECIDO}

Você está sendo convidado a participar da minha pesquisa de Mestrado em Linguística Aplicada na Universidade de Brasília (UnB) sobre a problematização de identidades sociais na sala de aula de francês. Esta pesquisa busca refletir sobre questões sociais ligadas às culturas francófona e brasileira e está sob a orientação da Profa. Dra. Mariana R. Mastrellade-Andrade (UnB).

Nesta pesquisa, o trabalho será feito com o método e os materiais de estudo previstos pela Aliança Francesa de Brasília, juntamente com materiais extras que abordam temas sociais e culturais. Quanto aos possíveis benefícios aos participantes deste estudo, destacamos a oportunidade de reflexão crítica acerca da realidade social em geral, competência cada vez mais demandada pelos exames nacionais e vestibulares.

Em vista disso, gostaria de solicitar a sua participação na coleta de dados para realização desta pesquisa. Os dados serão utilizados na elaboração da dissertação e em eventuais artigos e apresentações. A sua participação é de natureza voluntária, podendo, a qualquer momento, ser retirada sem nenhum tipo de perda ou prejuízo. Sob nenhuma forma serão divulgados os seus dados pessoais ou revelada a sua identidade quando da divulgação da pesquisa. Por essa razão, para participação, você pode escolher um pseudônimo (nome fictício):

Uma via original deste Termo de Consentimento Livre e Esclarecido ficará com você. Qualquer dúvida a respeito da pesquisa, você poderá entrar em contato comigo pelo telefone (61) 8318-5800 ou pelo e-mail: walescaporto@gmail.com.

Desde já, agradeço a sua atenção e colaboração para a realização desta pesquisa.

Brasília, de de 2016.

Walesca Afonso Alves Pôrto

$\mathrm{Eu}$, responsável pelo/a

CPF: , autorizo sua participação na pesquisa

citada acima, voluntariamente, após ter sido devidamente esclarecido/a. 


\section{APÊNDICE 11 - JOGO PARA SE CONHECER ${ }^{46}$}

\begin{tabular}{|c|c|c|c|c|c|c|c|}
\hline 1 & \begin{tabular}{|l} 
Fais une \\
petite \\
présentation \\
de toi.
\end{tabular} & $\begin{array}{l}\text { Quelle } \\
\text { est ta } \\
\text { couleur } \\
\text { préférée? }\end{array}$ & \begin{tabular}{|l} 
Un pays \\
qui \\
t'intéresse... \\
Pourquoi?
\end{tabular} & \begin{tabular}{|l|} 
Cite \\
trois \\
grandes villes \\
françaises.
\end{tabular} & $\begin{array}{l}\text { Présente un/e } \\
\text { des membres } \\
\text { de ton groupe } \\
\text { et parle de } \\
\text { lui/elle. }\end{array}$ & \begin{tabular}{|l} 
Quelle est \\
ta musique \\
préférée? \\
Chanteur/euse, \\
groupe, genre...
\end{tabular} & $\begin{array}{l}\text { Santé, } \\
\text { argent ou } \\
\text { amour? } \\
\text { Pourquoi? }\end{array}$ \\
\hline & & & & & & & $\begin{array}{l}\text { Parle un peu de } \\
\text { ton pays. } \\
\text { Comment sont } \\
\text { les gens? }\end{array}$ \\
\hline & & & & & & & $\begin{array}{l}\text { Présente ta } \\
\text { famille. }\end{array}$ \\
\hline $\begin{array}{l}\text { Quelle est ta } \\
\text { matière } \\
\text { préférée? }\end{array}$ & \begin{tabular}{|l} 
Ce que tu \\
possèdes de \\
plus \\
important.
\end{tabular} & $\begin{array}{l}\text { Parle un peu } \\
\text { da la France } \\
\text { ou d'un autre } \\
\text { pays } \\
\text { francophone. }\end{array}$ & \begin{tabular}{|l} 
Quel est ton \\
acteur \\
préféré ? Et \\
ton actrice \\
préférée?
\end{tabular} & $\begin{array}{l}\text { Dans quels } \\
\text { pays parle-t- } \\
\text { on français en } \\
\text { Europe? }\end{array}$ & $\begin{array}{l}\text { Ta meilleure } \\
\text { qualité et ton } \\
\text { pire défaut. }\end{array}$ & $\begin{array}{l}\text { Qu'est-ce que } \\
\text { tu portes } \\
\text { aujourd'hui? }\end{array}$ & $\begin{array}{l}\text { Quels sont tes } \\
\text { projets } \\
\text { d'avenir? }\end{array}$ \\
\hline \multicolumn{8}{|l|}{$\begin{array}{l}\text { Quelles sont } \\
\text { les choses que } \\
\text { tu aimes } \\
\text { faire? }\end{array}$} \\
\hline $\begin{array}{l}\text { Quel est le } \\
\text { dernier cadeau } \\
\text { que tu as } \\
\text { reçu? }\end{array}$ & $\begin{array}{l}\text { Décris la } \\
\text { femme ou le } \\
\text { mari idéal/e. }\end{array}$ & $\begin{array}{l}\text { Décris le lieu } \\
\text { où tu te } \\
\text { trouves. }\end{array}$ & $\begin{array}{l}\text { Ton livre } \\
\text { préféré et un } \\
\text { livre que tu as } \\
\text { détesté. }\end{array}$ & $\begin{array}{l}\text { Décris une } \\
\text { personne belle. } \\
\text { Elle/Il est } \\
\text { comment ? }\end{array}$ & $\begin{array}{l}\text { Pose une } \\
\text { question } \\
\text { indiscrète } \\
\text { à ton prof. }\end{array}$ & $\begin{array}{l}\text { J'étudie le } \\
\text { français parce } \\
\text { que... }\end{array}$ & \\
\hline
\end{tabular}

${ }^{46}$ Disponível em:

$<$ https://fr.islcollective.com/resources/printables/worksheets doc docx/jeu de loie expression_orale/jeudexpression-orale/20022>. Acesso em: 25 fev. 2016, 13:15:14. (com adaptações). 


\section{APÊNDICE 12 - ATIVIDADE I}

\section{Tema: Dia internacional da mulher}

\section{Objetivos:}

- Verificar as percepções das/os participantes sobre o dia internacional da mulher.

- Refletir sobre as conquistas femininas e sua importância para a sociedade contemporânea.

\section{Etapa 1)}

\section{Teste: Você é feminista? ${ }^{47}$}

1) Após uma breve reflexão sobre os possíveis entendimentos das/os participantes sobre o dia internacional da mulher, fazer o teste a seguir com toda a turma:

a) Você concorda que uma mulher deve receber o mesmo valor que um homem para realizar o mesmo trabalho?

b) Você concorda que mulheres devem ter direito a votarem e serem votadas?

c) Você concorda que mulheres devem ser as únicas responsáveis pela escolha da profissão, e que essa decisão não pode ser imposta pelo Estado, pela escola nem pela família?

d) Você concorda que mulheres devem receber a mesma educação escolar que os homens?

e) Você concorda que cuidar das crianças seja uma obrigação de ambos os pais? ?

f) Você concorda que mulheres devem ter autonomia para gerir seu dinheiro e seus bens?

g) Você concorda que mulheres devem escolher se, e quando, se tornarão mães?

h) Você concorda que uma mulher não pode sofrer violência física ou psicológica por se recusar a fazer sexo ou a obedecer ao pai ou marido?

i) Você concorda que atividades domésticas são de responsabilidade dos moradores da casa, sejam eles homens ou mulheres?

j) Você concorda que mulheres não podem ser espancadas ou mortas por não quererem continuar em um relacionamento afetivo?

\footnotetext{
${ }^{47}$ Disponível em: < https://cynthiasemiramis.org/teste-voce-e-feminista/>. Acesso em: 06 mar. 2016, 20:42:30.
} 


\section{APÊNDICE 13 - ATIVIDADE II}

Tema: Feminicídio

\section{Objetivos:}

- Discutir sobre casos de feminicídio no Brasil.

- Refletir sobre os motivos que levam um homem a cometer homicídio contra uma mulher.

\section{Etapa 1)}

\section{Música: Madeleine}

1) Análise da música Madeleine em grupos. Refletir com toda a turma.

\section{Imagem 46 - Madeleine de Jacques Brel}

\section{Madeleine de Jacques Brel}

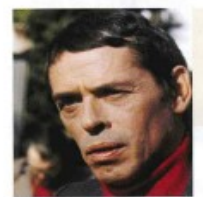

Jacques Brel (1929-1978), auteur-compositeur-interprète de chansons, est né en Belgique dans la banlieue de Bruxelles. A partir de 1958, le public reconnait la poesie et la force de ses textes, mais aussi la sincérité de son interprétation et c'est le succés. Jacques Brel part en tournee dans le monde entier. En 1967, il devient acteur et réalisateur de films. Malade, il abandonne tout en 1974 et part vivre aux iles Marquises, un archipel de la Polynésie française.
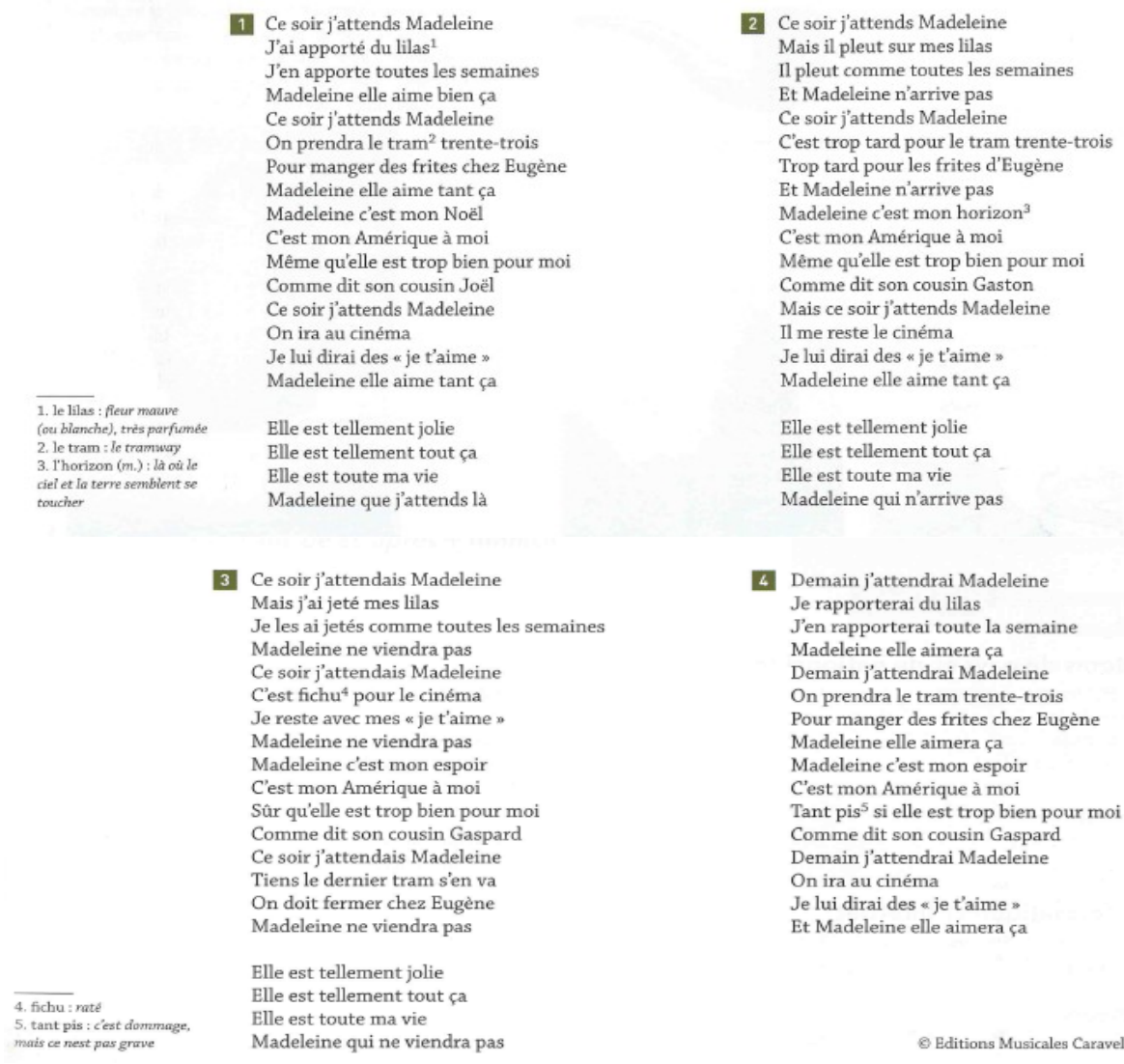

Fonte: Amis et compagnie 4, p. 6-7. 


\title{
Etapa 2)
}

1) Análisar dois casos de feminicído em Brasília em grupo. Discutir com toda a turma.

\author{
Imagem 47 - Caso de feminicídio $1^{48}$
}

\section{Aluna foi morta em laboratório da UnB após ser dopada com clorofórmio}

Corpo foi achado em uma área de cerrado no Setor de Clubes Norte. Aluno de biologia preso pelo homicídio confessou o crime, diz polícia.

\begin{abstract}
A estudante de biologia da Universidade de Brasilia (UnB) Louise Ribeiro foi assassinada por outro aluno da instituição após ser dopada com dorofórmio, informou a Polícia Militar do Distrito Federal. Segundo a Polícia Civil, a jovem morreu após ser forçada a ingerir o tóxico dentro do laboratório do curso por volta das $22 \mathrm{~h}$ desta quinta-feira (10).
\end{abstract}

\begin{tabular}{l}
\hline saiba mais \\
$\begin{array}{l}\text { Aluno da UnB é preso suspeito de matar } \\
\text { colega que rejeitou namoro }\end{array}$ \\
$\begin{array}{l}\text { Mulher tem namorado morto por ex após } \\
\text { virar conselheira tutelar no DF }\end{array}$ \\
$\begin{array}{l}\text { Por ciúme, marido acorrenta grávida pelas } \\
\text { pernas a cama no DF }\end{array}$
\end{tabular}

pernas a cama no DF
Nesta sexta de manhã, a PM prendeu o estudante Vinícius Neres, de 19 anos, pelo crime. De acordo com a polícia,ele confessou ter matado a garota, que tinha 20 anos. 0 motivo do homicídio teria sido a recusa da menina em ter um relacionamento com ele.

Na delegacia, a mãe do suspeito afirmou que agressor e vítima chegaram a namorar, mas que o rapaz já estava em outro relacionamento. "Meu filho nunca faria isso. Ele estava em casa à noite. Ele não é assassino", disse a mãe do suspeito, que pediu para não ter o nome divulgado.

O capitão da PM Jorge da Silva disse que Neres aparentava ter algum distúrbio psicológico. "O fato de ele ter muita calma e tranquilidade e por várias vezes estar sorrindo durante a confissão demonstra um comportamento de sociopatia e covardia."

O corpo da menina foi encontrado em uma área de cerrado no Setor de Clubes Norte, próximo à UnB, após indicação do local por Neres. O carro dela foi achado abandonado no estacionamento da universidade. Amigos da menina avisaram a polícia e disseram que Neres podia ter envolvimento como crime, devido à suposta fixação que 0 estudante tinha por Louise. estar sorrindo durante a confissão demonstra um comportamento de sociopatia e covardia"

O capitão Silva ligou para o estudante, que chegava à UnB, e marcou umencontro com ele. Após ser questionado pela polícia se havia tido contato coma menina, ele

acabou confessando o crime

O estudante disse que enrolou o corpo de Louise em um colchão inflável e o transportou no carro dela até o local onde ela foi encontrada. Neres ateou fogo ao rosto e à genitália da vítima. Segundo a policia, as queimaduras na genitália indicam a possibilidade de 0 suspeito ter violentado a estudante.

De acordo com a polícia, o estudante alegou que tinha a intenção de se matar após cometer o crime, mas desistiu do suicídio. Alguns amigos do suspeito e da vítima relataram que Neres possuía um "distúrbio psicológico" e já havia tentado suicídio três vezes, segundo a policia.

48 Disponível em: <http://g1.globo.com/distrito-federal/noticia/2016/03/aluna-foi-morta-em-laboratorio-da-unbpor-afogamento-em-cloroformio.html>. Acesso em: 13 mar. 2016, 14:34:23. 


\title{
Em Samambaia, rapaz mata namorada e depois se suicida
}

\author{
Crime ocorreu no início da tarde deste sábado \\ (12/3) na quadra 507. É o segundo crime contra \\ mulher que choca os brasilienses em pouco mais \\ de 24 horas
}

\begin{abstract}
Menos de 24 horas depois da descoberta do corpo da estudante da Universidade de Brasília (UnB) Louise Ribeiro, de 20 anos, morta por um colega da faculdade, um outro crime contra mulher choca os brasilienses. Segundo a Polícia Militar, Jhonata Pereira Alves, 23 anos, matou a namorada, Jane Carla Fernandes Cunha, 20, e se suicidou na tarde deste sábado (12/3), em Samambaia.
\end{abstract}

As primeiras informações revelam que o jovem não aceitou o fim do relacionamento e atirou contra ela. Segundo a Polícia Militar, o casal se separou há cerca de um mês, quando Jane Carla saiu de casa e foi morar com a mãe na casa onde morreu assassinada, localizada na quadra 507 de Samambaia.

Por volta das $13 \mathrm{~h}$, Jhonata tocou a campanhia e um primo da jovem, de apenas nove anos, abriu a porta para ele, que sacou a arma e saiu correndo atrás de Jane dentro do imóvel. De acordo com a PM, a mulher tentou se esconder no banheiro, mas foi baleada nas costas e cabeça, e caiu. Em seguida, o rapaz deu um tiro na própria cabeça e morreu. $\mathrm{O}$ primo ficou escondido e não foi atingido pelos disparos.

\begin{abstract}
Uma equipe do Serviço de Atendimento Móvel de Urgência (Samu) foi a primeira a chegar ao local. Jane ainda estava viva. Eles tentaram reanimá-la, mas não conseguiram. $O$ caso está sendo investigado pela $32^{\mathrm{a}}$ Delegacia de Polícia (Samambaia).
\end{abstract}

Mais de 40 familiares e amigos do casal estão na porta da casa onde ocorreu a tragédia. $O$ clima é de desespero. Eles não acreditam que os dois estão mortos. Sem querer se identificar, falaram que Jhonatan nào tinha nenhum histórico de violência. Os dois seriam estudantes, segundo os vizinhos informaram. Por volta das $18 \mathrm{~h}$, a Polícia Militar precisou intervir numa briga entre as duas famílias.

No caso de Louise, ela também foi morta por rejeitar um relacionamento com Vinícius Neres, de 19 anos. Ele confessou o crime e se entregou à polícia.

\footnotetext{
${ }^{49}$ Disponível em: $<$ http://www.metropoles.com/distrito-federal/em-samambaia-rapaz-mata-namorada-e-depoisse-suicida> . Acesso em: 13 mar. 2016, 15:02:56.
} 


\section{APÊNDICE 14 - ATIVIDADE III}

\section{Tema: Vantagens e desvantagens de ser homem e mulher na sociedade}

\section{Objetivos:}

- Analisar as percepções das/os participantes sobre os papéis sociais de homens e mulheres na sociedade, à maneira como entendem a dinâmica dessas identidades na sociedade, bem como as relações de poder entre elas.

- Refletir sobre os possíveis motivos dessas práticas sociais.

\section{Etapa 1)}

\section{Dinâmica: por que tanta diferenca?}

1) Dividir as/os participantes em grupos do sexo masculino e feminino.

2) Solicitar aos grupos do sexo masculino que discutam sobre as vantagens e desvantagens de ser mulher na sociedade.

3) Solicitar aos grupos do sexo feminino que discutam sobre as vantagens e desvantagens de ser homem na sociedade.

Após a discussão, as/os alunas/os deverão fazer uma lista com as referidas vantagens e desvantagens de ser homem ou mulher. Com a lista em mãos, cada grupo apresenta seus resultados.

Observação: nesta dinâmica de grupo, é proposital que os garotos pensem sobre as vantagens e desvantagens de ser mulher e vice-versa. Dessa forma, um sexo se colocará no lugar do outro.

\section{Debate:}

- Qual a origem dessas diferenças?

- Como essas diferenças são vistas em outras sociedades?

- Como essas diferenças afetam a vida dos homens e das mulheres?

- Quais das vantagens de ser homem ou mulher são reais e quais são estereotipadas?

- É possível ser homem e exercer alguns dos tópicos listados em "mulher" e vice-versa?

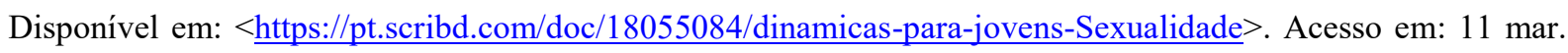
2016. 20:22:45 (com adaptações) 


\section{APÊNDICE 15 - ATIVIDADE VI}

Tema: Representações de mulheres brancas e negras

\section{Objetivos:}

- Analisar as representações das/os participantes a respeito de mulheres brancas e negras na sociedade.

- Discutir a supremacia branca e sua influência na construção de estereótipos.

\section{Etapa 1)}

\section{Dinâmica: Quem são elas?}

2) Observar as imagens de mulheres famosas brancas e negras e associá-las às suas profissões.
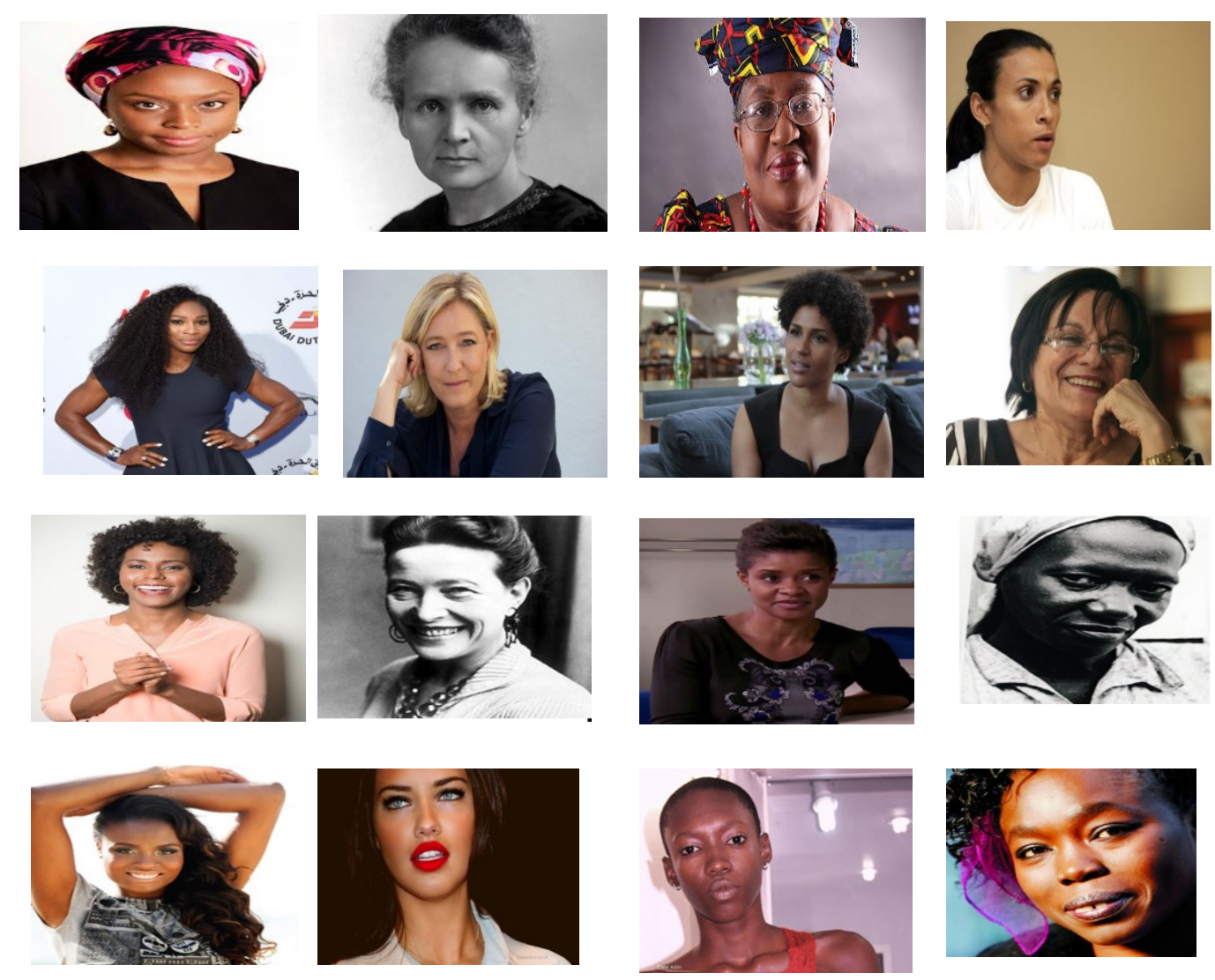

Profissões: écrivain, physicienne, femme politique, footballeuse, joueuse de tennis, consul française, pharmaceutique, journaliste, philosophe, scénariste, joueuese de volley-ball, manequin.

3) Discutir com as/os alunas/os, buscando saber o porquê de suas respostas.

4) Projetar o relato de uma professora negra universitária que conta o início da sua carreira. 


\section{APÊNDICE 16 - ATIVIDADE VIII}

Tema: O racismo à brasileira

\section{Objetivos:}

- Analisar as percepções das/os participantes sobre o racismo no Brasil.

- Refletir sobre frases racistas e preconceituosas presentes nas fotos de um ensaio fotográfico realizado na $\mathrm{UnB}^{50}$.

\section{Etapa 1)}

1) Questioná-las/os sobre o racismo no Brasil.

2) Observar as fotos contendo frases racistas e refletir sobre elas.
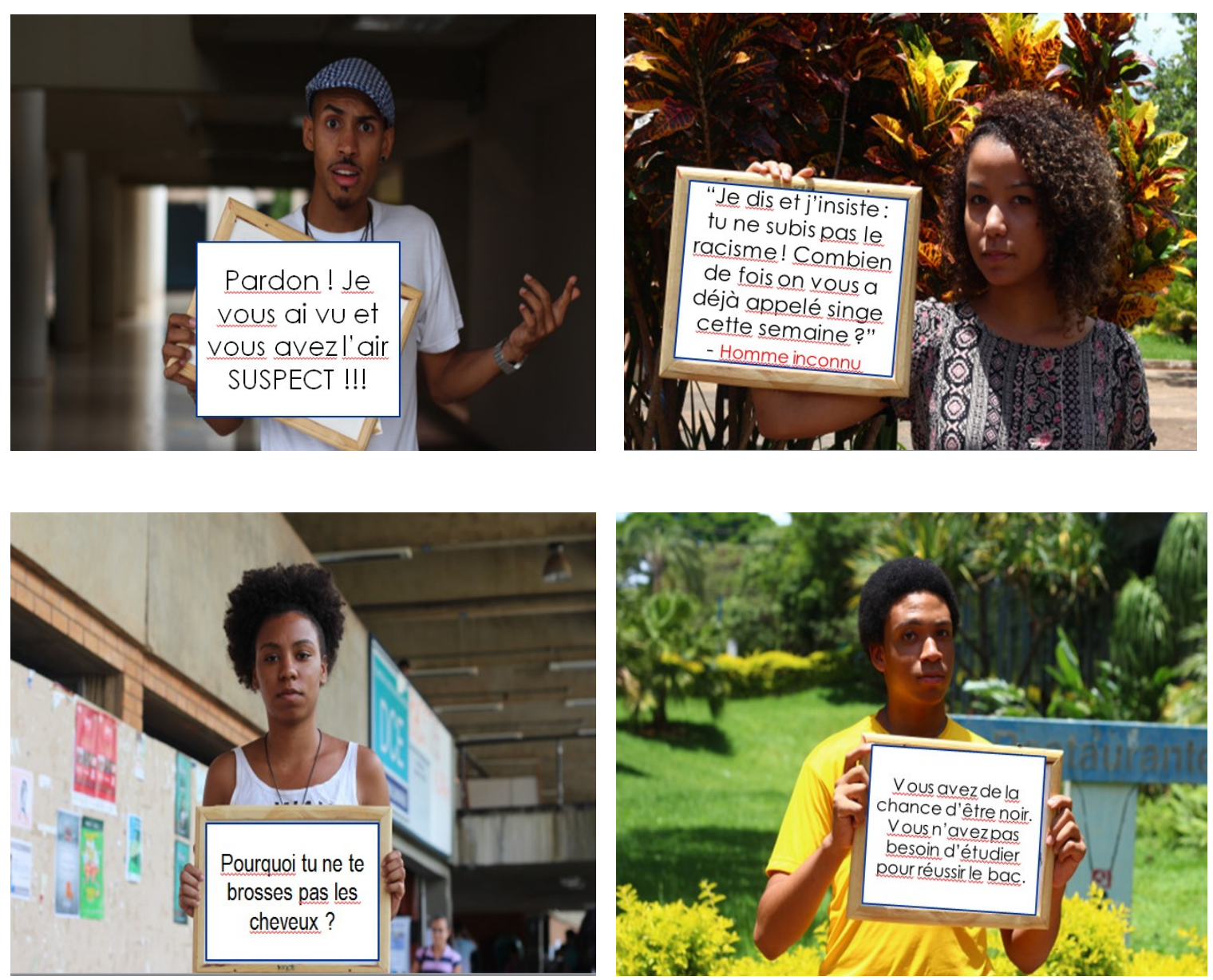

\footnotetext{
${ }^{50}$ Disponível em: $<$ http://ultimosegundo.ig.com.br/educacao/2015-04-06/aluna-da-unb-cria-projeto-fotograficopara-denunciar-racismo-em-universidade.html $>$. Acesso em: 03 jun. 2016, 22:34:21.
} 

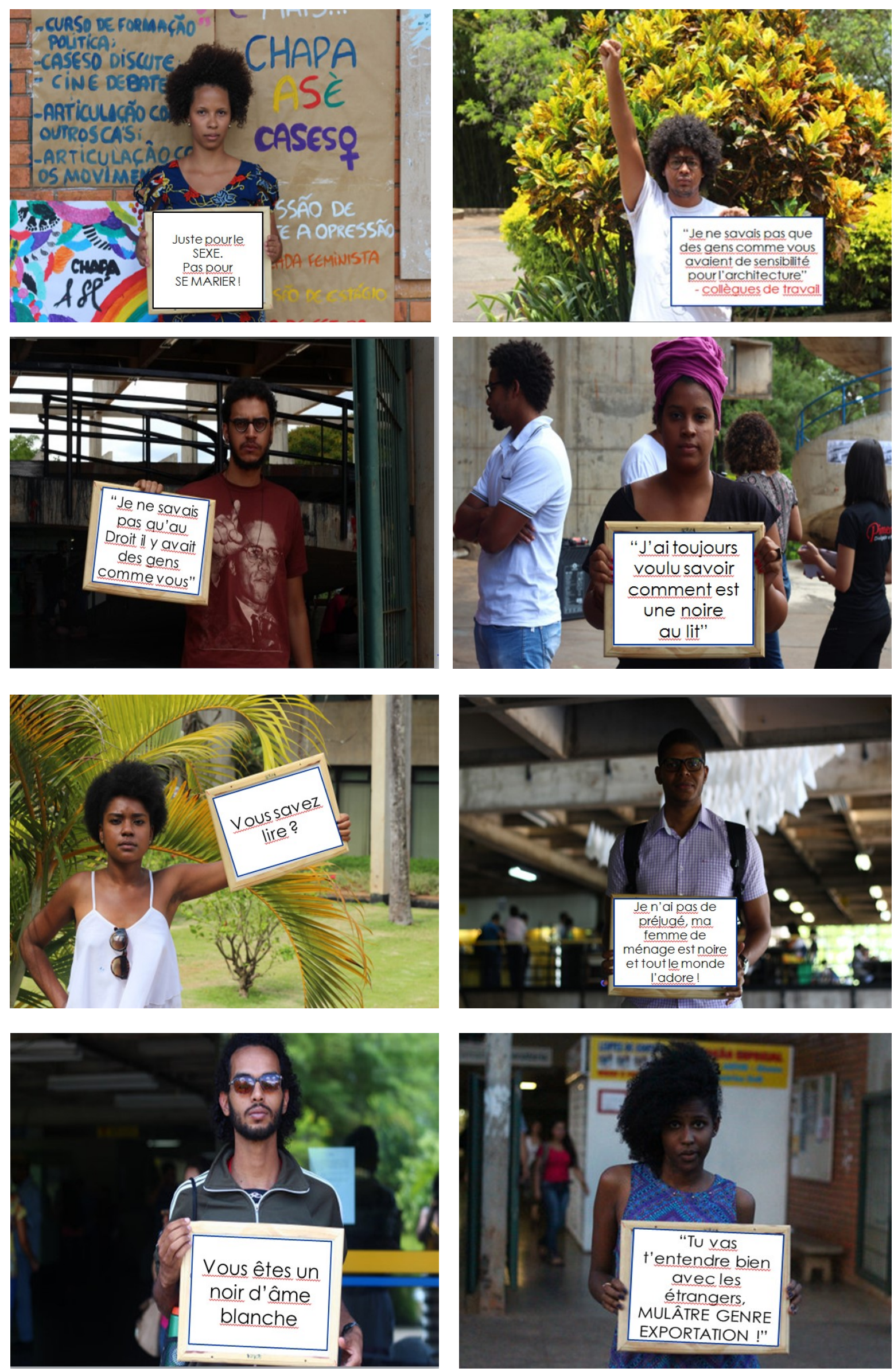

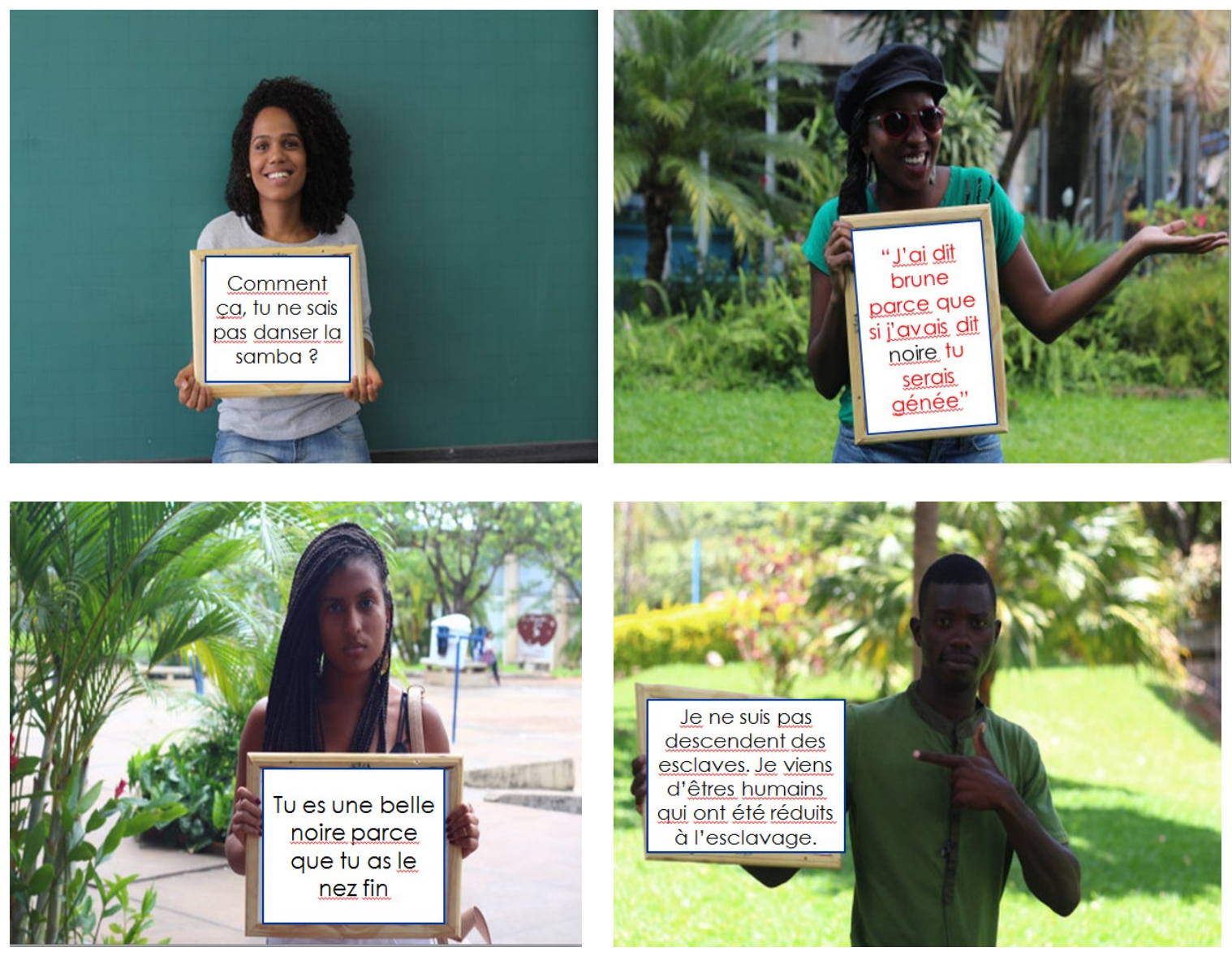